\title{
The impacts of century-old, arsenic-rich, mine tailings on multi- trophic level biological assemblages in lakes from the Cobalt, Ontario, Canada region
}

\author{
By
}

Amanda Little, B.Sc.

A thesis submitted to the Faculty of Graduate and Postdoctoral Affairs in partial fulfillment of the requirements for the degree of

\author{
Master of Science
}

in

Geography

Carleton University

Ottawa, Ontario

(C) 2019, Amanda Little 


\begin{abstract}
Silver mining in the early 1900s has left a legacy of arsenic-rich mine tailings around the town of Cobalt, in northeastern Ontario, Canada. Due to a lack of environmental control and regulations at that time, it was common for mines to dump their waste into adjacent lakes and land depressions, concentrating metals and metalloids in sensitive aquatic ecosystems. In order to examine what impacts, if any, these century-old, arsenic-rich, mine tailings are having on present day aquatic ecosystems we sampled diatom assemblages in lake surface sediment in 24 lakes along a gradient of surface water arsenic contamination $(0.4-972 \mu \mathrm{g} / \mathrm{L})$. In addition, we examined sedimentary cladocera and chironomid abundances and community composition, as well as open water zooplankton, and chlorophyll- $a$ concentrations over 10 of these study lakes along a gradient of arsenic contamination $(0.9-1,113 \mu \mathrm{g} / \mathrm{L})$. Our results show that present-day arsenic concentration is not a significant driver of biotic community change across the study lakes, suggesting that other variables such as lake depth and $\mathrm{pH}$ are more important in structuring the biological community across these lakes. These results suggest that while legacy contamination has greatly increased metal concentration beyond Canadian Council of Ministers of the Environment's (CCME) guideline for aquatic life $(5 \mu \mathrm{g} / \mathrm{L})$, variability in lake morphometry and water chemistry among the study lakes appears more important in the structuring of aquatic ecosystems in Cobalt, Ontario, Canada.
\end{abstract}




\section{ACKNOWLEDGEMENTS}

A huge thank you to everyone who has helped me throughout the journey that has been completing my Master's thesis at Carleton University. I would especially like to thank Dr. Jesse Vermaire for his continued guidance, patience, and support throughout this experience. It's been a pleasure learning from and working with you for the past three years. Thank you as well for all of the great networking opportunities you've provided for the lab, without which I likely wouldn't have made the decision to continue on with my studies at York University.

Thank you as well to all of the other graduate students who have helped me with this project. Thank you to Branaavan Sivarajah and Christina Frendo for their help with fieldwork and bio-indicator analysis, and for always being able to make me laugh. Thank you especially to Branaavan for always providing great advice, and for introducing me to so many wonderful people in the field of paleolimnology. Thank you to all of the other graduate students in my program and lab for their support, including but not limited to, Michael Murphy, Nicolas Pelletier, Mubashshera Rahman, and Colin Robertson.

Thank you as well to all of my friends and family who have patiently listened to me and helped me edit my coursework and thesis drafts, despite not knowing what words like "paleolimnology" and "paleo-ecotoxicology" mean. Thank you especially to Gwendolynn Little, John Little, and Ryan Tishcoff for always encouraging me to pursue my goals and stand up for what I believe in. I am truly blessed to be surrounded by so many caring, thoughtful, and supportive people. Thank you all so much. 


\section{LIST OF ABREVIATIONS}

${ }^{210} \mathbf{P b}-$ Lead -210

ABA - p-aminobenzenearsonic acid

Ag - Silver

As - Arsenic

$\mathbf{A s}\left(\right.$ III) - Inorganic tivalent arsenic (arsenite $\left.=\mathrm{AsO}_{3}{ }^{3-}\right)$

$\mathbf{A s}(\mathbf{V})$ - Inorganic pentavalent arsenic (arsenate $\left.=\mathrm{AsO}_{4}{ }^{3-}\right)$

BCF - Bioconcentration factor

CCME - Canadian Council of Ministers of the Environment

Co - Cobalt

DCA - Detrended Correspondence Analysis

DMA - Dimethylarsinic acid $\left(\left(\mathrm{CH}_{3}\right)_{2} \mathrm{As}(\mathrm{O}) \mathrm{OH}\right)$

DMSA - Disodium methylarsenate $\left(\mathrm{CH}_{3} \mathrm{AsO}(\mathrm{ONa})_{2}\right)$

$\mathbf{E C}_{16}$ - Sublethal concentration causing 16\% reduction (typically affecting reproduction) to exposed organisms

EC20 - Sublethal concentration causing 20\% reduction in growth to exposed organisms

EC $\mathbf{5 0}_{50}$ - Median effective concentration resulting in a 50\% reduction in growth rate or immobilization to exposed organisms

ECCC - Environment and Climate Change Canada

Ehrh. - Author name abbreviation for botanist Jakob Friedrich Ehrhart

EPA - Environmental Protection Agency (United States)

Fe - Iron

$\mathrm{H}_{2} \mathrm{O}_{2}$ - Hydrogen Peroxide

HCl - Hydrochloric Acid

$\mathrm{HNO}_{3}$ - Nitric Acid

IC $\mathbf{5 0}_{\mathbf{5 0}}$ - Inhibitory concentration impacting $50 \%$ of exposed organisms

ICP-AES - Induced Coupled Plasma - Atomic Emission Spectrometry

ICP-MS - Induced Coupled Plasma - Mass Spectrometry

KOH - Potsassium Hydroxide

L. - Author abbreviation for botanist Carl Linnaeus

$\mathbf{L} \mathbf{C}_{0}$ - Concentration where no exposed organisms are expected to die (just below threshold for lethality)

LC5 - Lethal concentration killing off 5\% of exposed organisms

LC20 - Lethal concentration killing off $20 \%$ of exposed organisms

LC50 - Lethal concentration killing off 50\% of exposed organisms

LC80 - Lethal concentration killing off $80 \%$ of exposed organisms

LC 100 - Lethal concentration killing off $100 \%$ of exposed organisms

LOEC - Lowest observed effect concentration

MATC $^{c}$ - Maximum acceptable toxicant concentration (chronic value)

Mn - Manganese

MSMA - Monosodium methanearsonate $\left(\mathrm{CH}_{4} \mathrm{AsNaO}_{3}\right)$

O- Oxygen

$\mathbf{P}-$ Phosphorus

$\mathbf{P O}_{3}{ }^{3-}-$ Phosphite

$\mathrm{PO}_{4}{ }^{3-}-$ Phosphate 
PCA - Pricinipal Component Analysis

RDA - Redundancy Analysis

SC - Sodium cacodylate $\left(\left(\mathrm{Ch}_{3}\right)_{2} \mathrm{AsO}_{2} \mathrm{H}\right)$

SDMA - Sodium dimethylarsenate $\left(\left(\mathrm{CH}_{3}\right)_{2} \mathrm{AsO}(\mathrm{ONa})\right)$

VSUE - Very severe unfavourable effect

Willd. - Author abbreviation for botanist Carl Ludwig Willdenow 


\section{TABLE OF CONTENTS}

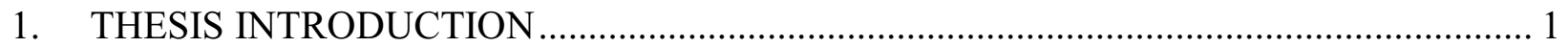

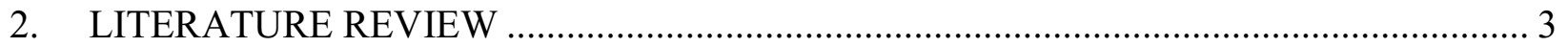

2.1: Geography of Cobalt, Ontario, Canada ......................................................................................

2.2: Mining History \& Legacy Contamination ..................................................................................... 6

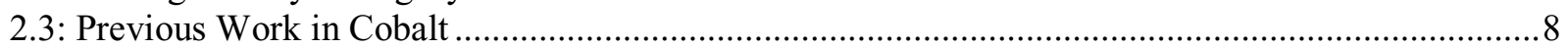

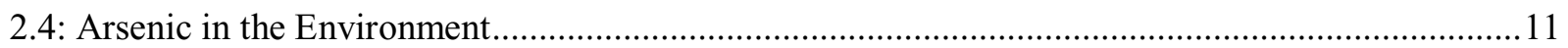

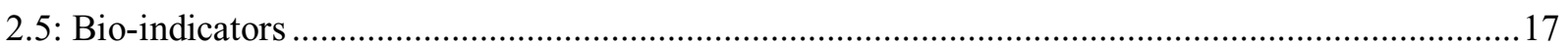

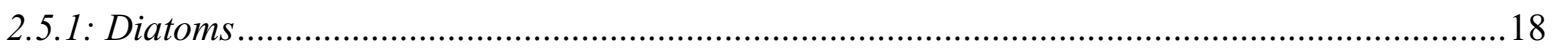

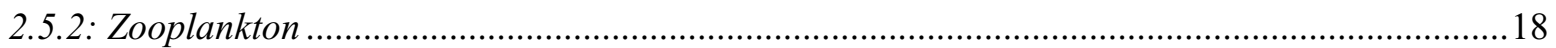

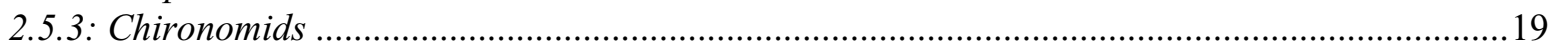

2.6: Biological Response to Short-term Arsenic Exposure …………………………………………...2

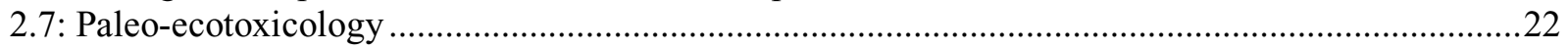

2.8: Biological Response to Long-term Arsenic Exposure …………………………………………....2

3. THE IMPACTS OF CENTURY-OLD, ARSENIC-RICH, MINE TAILINGS ON MULTITROPHIC LEVEL BIOLOGICAL ASSEMBLAGES IN LAKES FROM THE COBALT, ONTARIO CANADA REGION …………………........................................................ 34

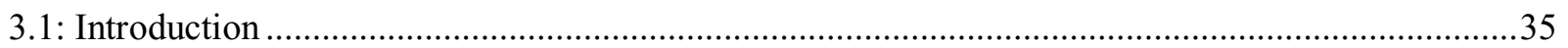

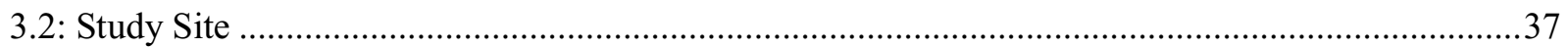

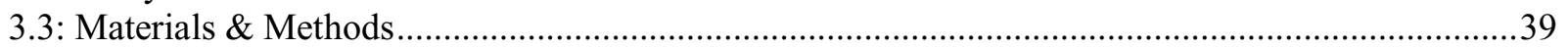

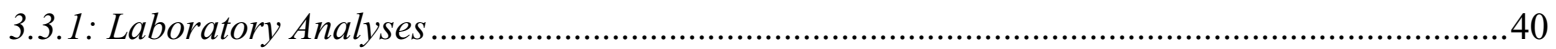

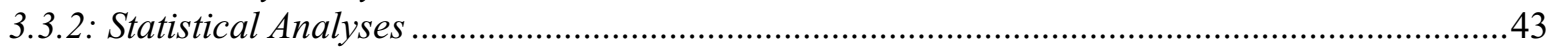

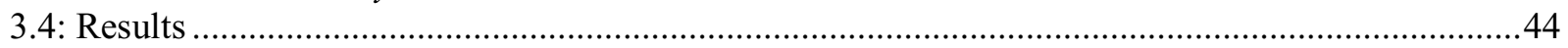

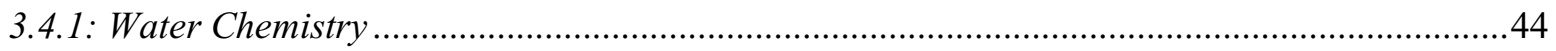

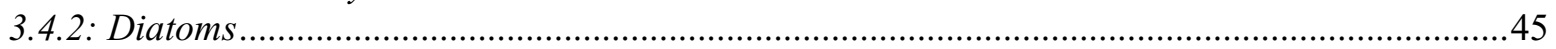

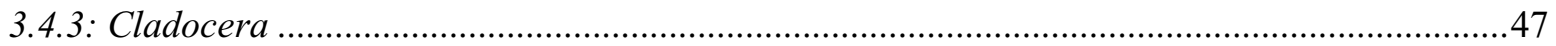

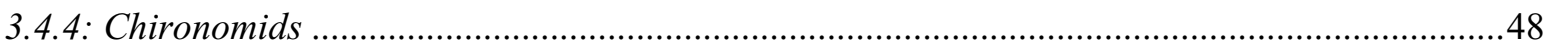

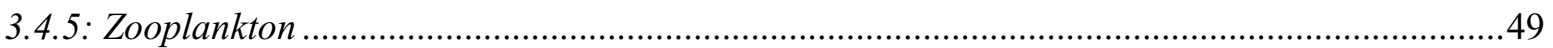

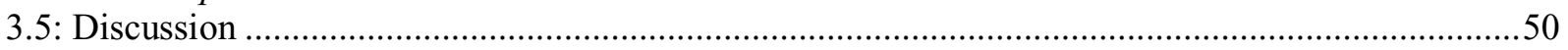

3.5.1: Impact(s) of surface water arsenic on bio-indicators in the Cobalt region .............................51

3.5.2: Influence of environmental variables on bio-indicators in lakes from the Cobalt region........56

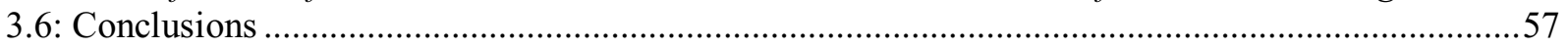

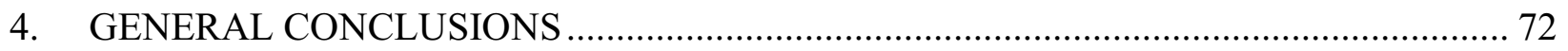

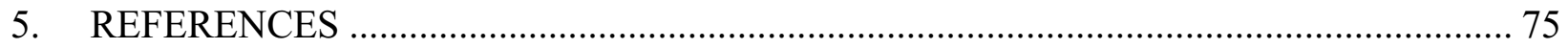

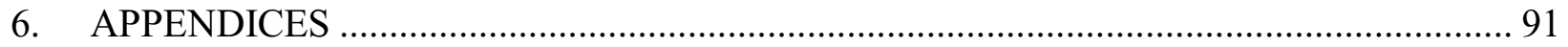

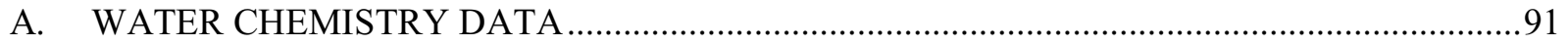

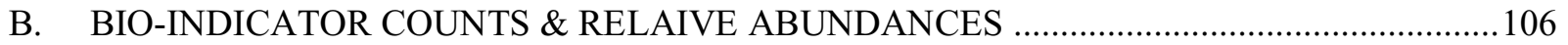

C. SUPPLEMENTARY SURFACE WATER ORDINATION DATA .........................................122

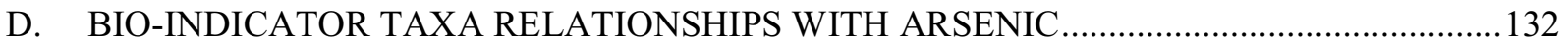

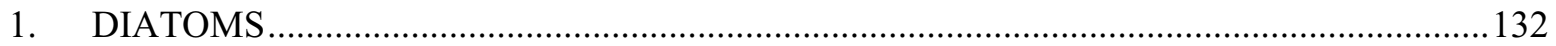

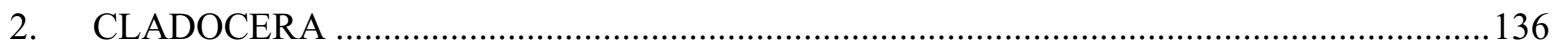

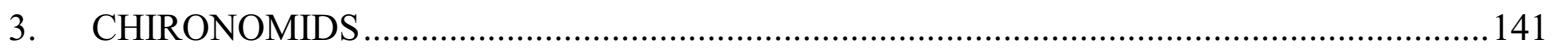

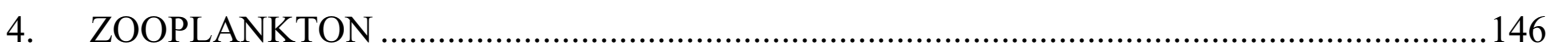

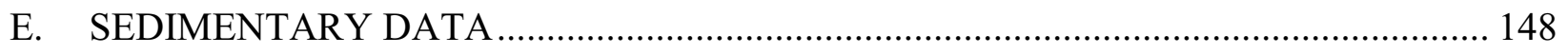




\section{LIST OF TABLES}

Table 2-1: Known arsenic toxicity data for freshwater organisms. Table modified from CCME 2001 and Eisler 1988.

Table 3-1: Surface water chemistry collected in 2015 from 24 lakes in the Cobalt, Ontario, Canada region. Chemical variables and individual numbers highlighted in grey indicate where a guideline has been breached. Lake contamination status indicated by $\mathrm{C}$ (contaminated) or $\mathrm{U}$ (uncontaminated).

Table 3-2: Surface water chemistry collected in 2017 from 10 lakes in the Cobalt, Ontario, Canada region which were found to be less than $70 \%$ correlated with one another. Chemical variables and individual numbers highlighted in grey indicate when a guideline has been breached.

Table 6-1: Surface water chemistry and environmental variable data from the 24-lake gradient from the Cobalt,

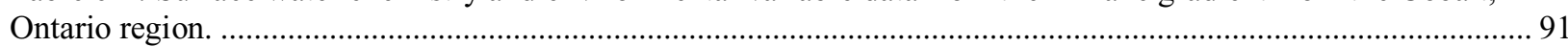

Table 6-2: Surface water chemistry and environmental variable data from the 10-lake gradient from the Cobalt, Ontario region.

Table 6-3: Correlation matrix for the raw 24-lake surface water data sampled in 2015. All variables found to have correlation of $\geq 0.70$ with one another were removed from further statistical analysis.

Table 6-4: Correlation matrix between computed PCA site scores and reduced environmental variables sampled in the 24-lake gradient from 2015. Cells highlighted red represent site scores or variables which are $\geq 0.70$ correlated with one another.

Table 6-5: Correlation matrix for the raw 10-lake surface water data sampled in 2017. All variables found to have correlation of $\geq 0.70$ with one another were removed from further statistical analysis............................................ 98 Table 6-6: Correlation matrix between computed PCA site scores for cladocera and reduced environmental variables sampled in the 10-lake gradient from 2017. Cells highlighted red represent site scores or variables which are $\geq 0.70$ correlated with one another......

Table 6-7: Correlation matrix between computed PCA site scores for chironomids and reduced environmental variables sampled in the 10-lake gradient from 2017. Cells highlighted red represent site scores or variables which are $\geq 0.70$ correlated with one another.

Table 6-8: Correlation matrix between computed PCA site scores for zooplankton and reduced environmental variables sampled in the 10-lake gradient from 2017. Cells highlighted red represent site scores or variables which are $\geq 0.70$ correlated with one another.

Table 6-9: Identified diatom species and their respective count total observed in each lake across the 24-lake arsenic gradient from the Cobalt, Ontario region. 106

Table 6-10: Diatom species identified as common ( $>2 \%$ abundance in at least 1 lake) and their relative abundance observed in each lake across the 24-lake arsenic gradient from the Cobalt, Ontario region.

Table 6-11: Identified Cladocera species and their respective count total observed in each lake across the 9-lake (data missing for Kerr Lake) arsenic gradient from the Cobalt, Ontario region.

Table 6-12: Cladocera species identified as common ( $>2 \%$ abundance in at least 1 lake) and their relative abundance observed in each lake across the 9-lake (data missing for Kerr Lake) arsenic gradient from the Cobalt, Ontario region.

Table 6-13: Identified Chironomid species and their respective count totals observed in each lake across the 10-lake

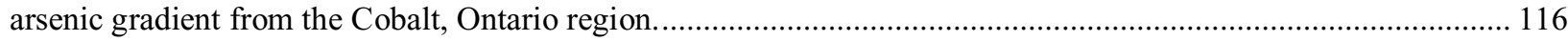
Table 6-14: Chironomid species identified as common ( $>5 \%$ abundance in at least 1 lake) and their relative abundance observed in each lake across the 10-lake arsenic gradient from the Cobalt, Ontario region................... 118 Table 6-15: Identified open water zooplankton families and their averaged count totals observed in each lake across the 10-lake arsenic gradient from the Cobalt, Ontario region.

Table 6-16: Open water zooplankton families identified as common ( $>2 \%$ abundance in at least 1 lake) and their relative abundance observed in each lake across the 10-lake arsenic gradient from the Cobalt, Ontario region. ..... 121 Table 6-17: De-trended correspondence analysis (DCA) results for the 24-lake gradient and diatom species data. 122 Table 6-18: Principal component analysis (PCA) results for the 24-lake gradient and diatom species data. Only the

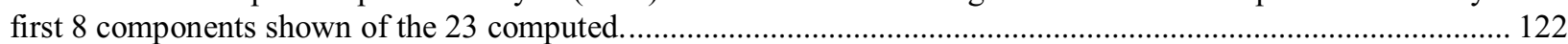
Table 6-19: Site scores for the 24-lake gradient and diatom PCA data.......................................................... 122 Table 6-20: Redundancy analysis (RDA) biplot scores for the 24-lake gradient and diatom species data.............. 123 Table 6-21: De-trended correspondence analysis (DCA) results for the 9-lake gradient and cladocera species data.

Table 6-22: Principal component analysis (PCA) results for the 9-lake gradient and cladocera species data. ........... 124 
Table 6-23: Site scores for the 9-lake gradient and cladocera PCA data.

Table 6-24: Redundancy analysis (RDA) biplot scores for the 9-lake gradient and cladocera species data............ 125

Table 6-25: De-trended correspondence analysis (DCA) results for the 10-lake gradient and chironomid species data.

Table 6-26: Principal component analysis (PCA) results for the 10-lake gradient and chironomid species data. Only

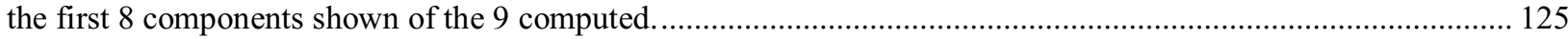

Table 6-27: Site scores for the 10-lake gradient and chironomid PCA data..................................................... 125

Table 6-28: Redundancy analysis (RDA) biplot scores for the 10-lake gradient and chironomid species data........ 126

Table 6-29: De-trended correspondence analysis (DCA) results for the 10-lake gradient and zooplankton species

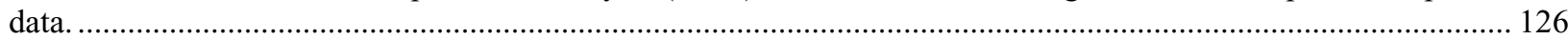

Table 6-30: Principal component analysis (PCA) results for the 10-lake gradient and zooplankton species data. Only

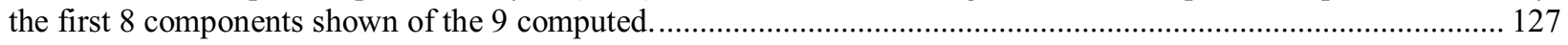

Table 6-31: Site scores for the 10-lake gradient and zooplankton PCA data. ................................................ 127

Table 6-32: Redundancy analysis (RDA) biplot scores for the 10-lake gradient and zooplankton species data. ..... 127

Table 6-32: Sediment chemistry data from the 24-lake gradient from the Cobalt, Ontario region.................158

\section{LIST OF FIGURES}

Figure 2-1: Map showing the location of Cobalt within the province of Ontario, Canada. Ontario has been divided into five regions (southern, southwestern, central, eastern, and northern). The Great Lakes are shown in light grey.

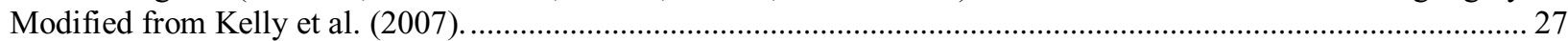
Figure 3-1: Map of Cobalt, Ontario, Canada with study lakes highlighted and the Silver Centre region indicated to the south. Lakes marked with green circles are currently uncontaminated, lakes marked with red circles are contaminated with mining-related arsenic. Lakes indicated with a star are included in the 10-lake gradient subsample study. Lakes are shaded by the amount of arsenic present with lighter reds indicating lower levels of arsenic and darker reds indicating higher levels. Only water bodies indicated as used in this study are shaded with their

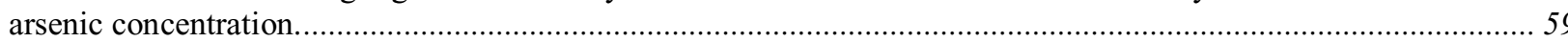
Figure 3-2: Plot of diatom indicator taxa found at $\%$ or higher in at least one of the 24 lakes within the Cobalt, Ontario region. Lakes and diatom taxa have both been sorted from lowest to highest arsenic levels in order to show a potential relationship between arsenic and diatoms. Lakes located in the black box are currently uncontaminated

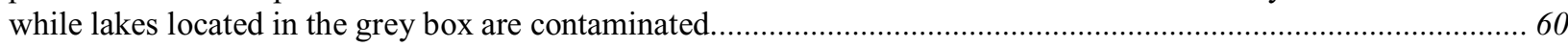
Figure 3-3: A) Principal component analysis (PCA) of the most common diatom taxa found in the 24 lakes in the Cobalt, Ontario region along the PC1 and PC2 axes. PC1 was found to explain $21 \%$ of the variance within the dataset while PC2 explains 13\%. All contaminated lakes are indicated with a black triangle, while currently uncontaminated lakes are marked by black circles. Full taxa names and corresponding abbreviations can be found in Supplementary Table 1. B) Redundancy analysis (RDA) of the most common diatom taxa and selected chemical variables within the 24 lakes along RDA axes 1 and 2. Grey lines indicate the direction and strength of the explanatory chemical variables while lakes are indicated by black circles and diatoms by abbreviated names. RD1 was found to explain $18 \%$ of the variance within the dataset while RD2 explains $11 \%$.

Figure 3-4: Plots of PC1 axes of the bio-indicator site scores versus surface water arsenic concentration - A)

diatoms, B) Cladocera, C) chironomids, D) zooplankton. None of these relationships were statistically significant. 62 Figure 3-5: Plot of some of the most common Cladocera, chironomid, and open water zooplankton indicator taxa along the 10 lake gradient from the Cobalt, Ontario region. Chlorophyll-a concentrations included on the right. Lakes which are currently uncontaminated are highlighted with black boxes, while lakes contaminated with miningrelated arsenic are highlighted in grey boxes.

Figure 3-6: Principal component analysis (PCA) ordination plots for Cladocera (A), chironomid (B), and zooplankton (C) indicator taxa. Lakes indicated with black triangles are contaminated, while lakes marked with a black circle are currently uncontaminated. Full taxa names and corresponding abbreviations can be found in Supplementary Table 3-1. A) Cladocera along the 10-lake gradient. PC1 explains 31\% of the variance within the dataset while PC2 explains 25\%. B) Chironomids along the 10-lake gradient. PC1 explains 20\% of the variance 
within the dataset while PC2 explains 18\%. C) Zooplankton along the 10-lake gradient. PC1 explains $35 \%$ of the variance within the dataset while PC2 explains $20 \%$.

Figure 6-1: Corrplot matrices corresponding to the correlation between chemical and environmental variables sampled in the 24-lake gradient. Bigger circles correspond to higher rates of correlation, with red colours relating to negative relationships and blue colours corresponding with positive relationships. The matrix on the left shows all of the raw chemical and environmental variables sampled from the Cobalt, Ontario region, while the matrix on the right showcases the remaining variables after those with $\geq 0.70$ correlation were removed................................... 95 Figure 6-2: Corrplot matrix corresponding to the correlation between computed PCA site scores and environmental variables sampled in the 24-lake gradient. Bigger circles correspond to higher rates of correlation, with red colours relating to negative relationships and blue colours corresponding with positive relationships.

Figure 6-3: Corrplot matrices corresponding to the correlation between chemical and environmental variables sampled in the 10-lake gradient. Bigger circles correspond to higher rates of correlation, with red colours relating to negative relationships and blue colours corresponding with positive relationships. The matrix on the left shows all of the raw chemical and environmental variables sampled from the Cobalt, Ontario region, while the matrix on the right showcases the remaining variables after those with $\geq 0.70$ correlation were removed

Figure 6-4: Corrplot matrix corresponding to the correlation between computed PCA site scores for cladocera and environmental variables sampled in 2017 along the 10-lake gradient. Bigger circles correspond to higher rates of correlation, with red colours relating to negative relationships and blue colours corresponding with positive relationships.

Figure 6-5: Corrplot matrix corresponding to the correlation between computed PCA site scores for chironomid and environmental variables sampled in 2017 along the 10-lake gradient. Bigger circles correspond to higher rates of correlation, with red colours relating to negative relationships and blue colours corresponding with positive relationships.

Figure 6-6: Corrplot matrix corresponding to the correlation between computed PCA site scores for zooplankton and environmental variables sampled in 2017 along the 10-lake gradient. Bigger circles correspond to higher rates of correlation, with red colours relating to negative relationships and blue colours corresponding with positive relationships.

Figure 6-7: Contaminated lakes are indicated by black triangles, while currently uncontaminated lakes are represented by black circles. RDA ordination plot for diatom taxa from 24 lakes in the Cobalt, Ontario, Canada region. RDA1, or arsenic, explains $4 \%$ of the variance in the data.

Figure 6-8: Contaminated lakes are indicated by black triangles, while currently uncontaminated lakes are represented by black circles. A) RDA ordination plot for cladocera taxa from 9 lakes in the Cobalt, Ontario, Canada region. RDA1 explains $29 \%$ of the variance in the data, while RDA2 explains $21 \%$. B) RDA ordination plot using only arsenic from the 9 lakes as an explanatory variable. Arsenic was found to explain $\sim 15 \%$ of the total variance in the cladocera taxa.

Figure 6-9: Contaminated lakes are indicated by black triangles, while currently uncontaminated lakes are represented by black circles. A) RDA ordination plot for chironomid taxa from 10 lakes in the Cobalt, Ontario, Canada region. RDA1 explains $17 \%$ of the variance in the data, while RDA2 explains $15 \%$. B) RDA ordination plot using only arsenic from the 10 lakes as an explanatory variable. Arsenic was found to explain $\sim 8 \%$ of the total variance in the chironomid taxa.

Figure 6-10: Contaminated lakes are indicated by black triangles, while currently uncontaminated lakes are represented by black circles. A) RDA ordination plot for zooplankton taxa from 10 lakes in the Cobalt, Ontario, Canada region. RDA1 explains $31 \%$ of the variance in the data, while RDA2 explains $17 \%$. B) RDA ordination plot using only arsenic from the 10 lakes as an explanatory variable. Arsenic was found to explain $\sim 13 \%$ of the total variance in the zooplankton taxa............................................................................................................ 131 Figure 6-11: Diatom taxa 1-6 versus surface water arsenic from the 24-lake gradient from around the Cobalt, Ontario, Canada region.

Figure 6-12: Diatom taxa 7-12 versus surface water arsenic from the 24-lake gradient from around the Cobalt, Ontario, Canada region.

Figure 6-13: Diatom taxa 13-18 versus surface water arsenic from the 24-lake gradient from around the Cobalt,

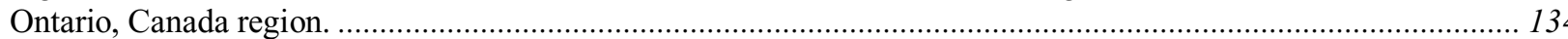

Figure 6-14: Diatom taxa 19-24 versus surface water arsenic from the 24-lake gradient from around the Cobalt, Ontario, Canada region.

Figure 6-15: Diatom taxa 25-26 versus surface water arsenic from the 24-lake gradient from around the Cobalt, Ontario, Canada region. 
Figure 6-16: Cladocera taxa 1-6 versus surface water arsenic from the 10-lake gradient from around the Cobalt, Ontario, Canada region.

Figure 6-17: Cladocera taxa 7-12 versus surface water arsenic from the 10-lake gradient from around the Cobalt,

Ontario, Canada region.

Figure 6-18: Cladocera taxa 13-18 versus surface water arsenic from the 10-lake gradient from around the Cobalt,

Ontario, Canada region.

Figure 6-19: Cladocera taxa 19-21 versus surface water arsenic from the 10-lake gradient from around the Cobalt,

Ontario, Canada region.

Figure 6-20: Chironomid taxa 1-6 versus surface water arsenic from the 10-lake gradient from around the Cobalt,

Ontario, Canada region.

Figure 6-21: Chironomid taxa 7-12 versus surface water arsenic from the 10-lake gradient from around the Cobalt,

Ontario, Canada region. 142

Figure 6-22: Chironomid taxa 13-18 versus surface water arsenic from the 10-lake gradient from around the Cobalt,

Ontario, Canada region. 143 Figure 6-23: Chironomid taxa 19-24 versus surface water arsenic from the 10-lake gradient from around the Cobalt, Ontario, Canada region. 144 Figure 6-24: Chironomid taxa 25-27 versus surface water arsenic from the 10-lake gradient from around the Cobalt, Ontario, Canada region. 145 Figure 6-25: Zooplankton taxa 1-6 versus surface water arsenic from the 10-lake gradient from around the Cobalt, Ontario, Canada region. 146 Figure 6-26: Zooplankton taxa 7-9 versus surface water arsenic from the 10-lake gradient from around the Cobalt, Ontario, Canada region.

\section{LIST OF SUPPLEMENTARY TABLES \& FIGURES}

Supplementary Table 3-1: Bio-indicator taxa short forms used in ordination plots.

Supplementary Figure 3-1: Box and whisker plot showing the difference in means between surface water arsenic concentration $(\mu \mathrm{g} / \mathrm{L})$ in lakes classified as contaminated (13) and uncontaminated (11). Relationship determined to be statistically significant $(\mathrm{p}<0.01)$

Supplementary Figure 3-2: Box and whisker plot showing the difference in means between surface water chlorophyll-a (mg/L) concentration in lakes classified as contaminated (6) and uncontaminated (4). Relationship determined to be not statistically significant $(p=0.19)$.

Supplementary Figure 3-3: Scatterplot of PC1 site scores from the 24-lake gradient versus lead concentrations in lakes from the Cobalt, Ontario region.

Supplementary Figure 3-4: Scatterplot of PC1 site scores from the 24-lake gradient versus $\mathrm{pH}$ in lakes from the Cobalt, Ontario region.

Supplementary Figure 3-5: Scatterplot of PC1 site scores from the 24-lake gradient versus water depth in lakes from the Cobalt, Ontario region.

Supplementary Figure 3-6: Barplot showing the general trend of chironomid totals decreasing in lakes with higher arsenic concentrations. 


\section{THESIS INTRODUCTION}

Cobalt, Ontario, Canada was once the world's largest producer of silver. Discovered in 1903, the silver mining industry in the region peaked in 1911, with 40 separate mines contributing to the 30 million ounces of silver produced that year alone (Barnes 1986). Due to the methods and technology available at the time, in conjunction with weak environmental protective legislation, much waste arsenic was produced in tandem with the silver extracted. It has been estimated that over 2.5 billion ounces of arsenic was produced during the silver mining boom in the Cobalt region (Thomson 1964). This waste arsenic was dumped wherever was most convenient at the time, and has subsequently made its way into many of the lakes and streams in and around Cobalt. Despite the fact that no mines have been in operation in the area since the late 1980s, no remediation efforts have been made, and thus, much of the arsenic found in the region has been present in the environment for over a century. As a result, there is concern about the potential impact that this legacy arsenic has had on exposed aquatic ecosystems in the Cobalt area.

Despite the known health risks of arsenic, little is known about the long-term impacts of arsenic in the environment. The majority of data currently available to assess the impacts of arsenic are almost entirely exclusive to short-term, in-lab experiments, typically lasting from hours to a few weeks in length (Table 2-1). As a result, the Cobalt region represents an important study site for researchers interested in the long-term (decades and longer) impacts of mining-related contaminants like arsenic, in the environment. Therefore, the main objective of this thesis was to investigate the potential impacts that mining-related arsenic has had on the aquatic ecosystems of lakes along a spatial gradient in the Cobalt, Ontario, Canada region. 
In order to meet this objective, water and sediment samples taken during the summers of 2015 and 2017 were analyzed in order to quantify the chemical variables, including total arsenic, present in both contaminated and uncontaminated lakes in the region. These results were then compared to the biological community structures present in each lake along the spatial gradient of arsenic. A discussion of the methods, results, and possible implications of the findings of this study can be found in Chapter 3 of this thesis.

This thesis is presented in a paper format. Chapter 1 provides a brief introduction to the thesis and contextualizes the problem of long-term arsenic exposure to aquatic ecosystems in lakes from the Cobalt, Ontario, Canada region. Chapter 2 explores relevant literature currently available as related to Cobalt as the study site for this thesis, how arsenic behaves in the environment, the bio-indicators used in this research, and current techniques and frameworks in the fields of paleolimnology, ecotoxicology, and paleo-ecotoxicology. Chapter 3 explores the impacts of century-old, arsenic-rich mine tailings on multi-trophic level biological assemblages in lakes from the Cobalt, Ontario, Canada region, and includes descriptions of the methods used, and results of the study. Chapter 4 summarizes the main findings and conclusions of the research presented by this thesis. Information regarding bio-indicator counts, chemical variables measures, and more ordination results are available in Chapter 6, the appendices. 


\section{LITERATURE REVIEW}

Legacy contamination associated with historical mining practices is a well-documented global environmental problem. In Canada, much of this pollution is due to the lack of environmental regulations that were in effect during the onset of mining in the country. As a result, many abandoned mining sites in Canada are still highly contaminated with potentially harmful levels of mining-related waste materials (Tenkouano et al. 2019; Stewart et al. 2018; Thienpont et al. 2016; Cattaneo et al. 2004). One such site is the town of Cobalt, Ontario, which at the height of mining produced over 30 million ounces of silver within a single year (1911) (Barnes 1986). Due to the geology of the region, arsenic and other harmful substances were also unearthed alongside the silver ore. Mining in the Cobalt region was active from the early 1900s until the late $1980 \mathrm{~s}$, and it has been estimated that over 2.5 billion ounces of waste arsenic was produced. It was common practice at the time to dispose of mining waste material in the most efficient and cost-effective way possible, which meant that much of this arsenic ended up in nearby land depressions such as lakes and streams (Thomson 1964).

Although arsenic is a naturally occurring element, mine tailings in the Cobalt region represent a significant potential threat to both human and ecosystem health, as arsenic is a known carcinogen and toxicant (Sprague et al. 2016; Wang \& Mulligan 2006). Despite the known risks of arsenic to aquatic ecosystems, the majority of data currently available to assess arsenic impacts in freshwater ecosystems are from short-term, in-lab, experiments typically lasting from a few hours to weeks in length (Table 2-1). As a result, despite the fact that significant and widespread documentation of arsenic contamination exists, relatively little is known about its long-term environmental impacts in aquatic ecosystems (Nikolaidisa et al. 2004). The Cobalt region therefore represents an important study site for the investigation of long-term impacts of 
arsenic and other mining-related contaminants in the environment.

\section{1: Geography of Cobalt, Ontario, Canada}

Cobalt $\left(47^{\circ} 24^{\prime} \mathrm{N}, 79^{\circ} 41^{\prime} \mathrm{W}\right)$ is a small town in northeastern Ontario, Canada, located approximately $480 \mathrm{~km}$ north of the city of Toronto (Figure 2-1). Established in 1906 and incorporated in 1907, Cobalt is currently home to over 1,100 people (2016). Signs of past mining activities such as waste rock piles, mine shafts, and mine tailings, are common place on the landscape as the town was built on an underground honeycomb of old mining tunnels and trenches, which are now abandoned (Bochove 2017). The area is situated between a clay belt to the north and a region of mixed forest to the south. It is classified as having a severe humid continental climate and is therefore host to moderately warm summers followed by cold and long winters. The region has a mean annual precipitation of $820 \mathrm{~mm}$ (ECCC 2019). The mean annual temperature ranges from a low of $-17.8^{\circ} \mathrm{C}$ during the winter months (December, January, February) to $23^{\circ} \mathrm{C}$ during the summer months (June, July, August) (ECCC 2019).

The geological makeup of the region is based on Archean volcanics, and is overlain with Proterozoic sediments from the Cobalt Group consisting of the Lorrain and Gowganda formations (Jambor 1971). All of the rock units found within the Cobalt Group are cut by Proterozoic Nipissing diabase, which is host to the majority of silver deposits in the region (Jambor 1971). This silver is found in naturally occurring veins alongside gold, arsenic and bismuth, as well as arsenides, sulfarsenides and other sulfides, such as nickeline, cobaltite and galena. These veins vary in width from a few millimeters to over 1.2 meters (Petruk 1971). Some of the richest veins discovered in the region were originally found on the west and east sides of Cobalt Lake (Parks 1904; Miller 1903). 
Soil $\mathrm{pH}$ in the region ranges from slightly acidic (6.14) in forested areas, to more alkaline (8.04) where mine tailings exist due to the presence of calcite and dolomite materials and the absence of sulfide minerals left in the ore (Michel \& Henein 2007). This trend was also observed in surface water samples taken from lakes in the region, with more highly contaminated lakes found to have higher pH levels (Michel \& Henein 2007). While more alkaline conditions in the region have resulted in a lack of acid mine drainage typical of historical mining sites, many of the exposed tailings sites have remained relatively free of vegetation despite the cessation of industrial activity decades ago (Michel \& Henein 2007). This is likely due to the fact that much of the tailings are made up of sand-sized materials, which drain rapidly after rainfall events, making moisture retention difficult. A lack of nutrients and the overall toxicity of materials found in the tailings may also be limiting factors for the re-growth of vegetation in contaminated areas (Michel \& Henein 2007). Two species of vegetation, which can be found in otherwise sparse areas on the tailings include Equisetum pratense Ehrh. (horsetail) and Juncus balticus Willd. (rush) (Michel \& Henein 2007). Typha latifolia L. (cattails) are the most abundant vegetation in the wetlands found around contaminated lakes, and are typically enriched with metals, which may be due to direct contact from tailings, or through the removal of dissolved metals in water (Michel \& Henein 2007; Kelly 2006).

The majority of waterbodies in this area flow into the Farr Creek drainage basin, which then flows north of Cobalt and eventually into Lake Temiskaming and the Ottawa River. The Ottawa River acts as a natural border between the provinces of Ontario and Quebec for over 600 $\mathrm{km}$ and is classified as a Canadian Heritage River for its cultural and economic importance to the country. 


\section{2: Mining History \& Legacy Contamination}

In 1903, silver was discovered along Mile 103 during the construction of the railway from North Bay to farming communities located along the shores of Lake Temiskaming in northern Ontario (Barnes 1986). This area would eventually become known as the town of Cobalt, Ontario, Canada and remains famous for its large, natural silver and cobalt deposits, as well as for its subsequent role in the establishment of early mining industries and therefore economic development in Ontario. Occurring at around the same time as the Klondike goldrush in the Yukon Territory, the discovery at Cobalt has been argued to be more historically important for Canada. This is due to how the mining activities in the Cobalt region continued to influence and solidify Canada's reputation as a mining powerhouse, even after the final mines were shut down in the 1980s (Baldwin \& Duke 2005; Kelly et al. 2007). Named Ontario's "Most Historic Town" in 2001, and declared a National Historic Site in 2002, Cobalt has been recognized as the birthplace of hard-rock mining in Canada, and the activities which took place in the region helped to pave the way for future exploration, mining, and settlement in both northern Ontario and Québec, as well as globally (Dumaresq 2009).

Established in 1906 after the discovery of silver and subsequent rush to prospect the region, Cobalt quickly became known as one of the largest silver mining camps in the world. By 1905, 16 mines had been established in the area and by 1911 this number had jumped to over 40, which resulted in the production of 30,000,000 oz of silver that year alone (Barnes 1986). Further exploration of the region resulted in the creation of other secondary mining camps in the Elk Lake, South Lorrain (known as Silver Centre), and Gowganda areas in 1906 and 1907 (McIlwaine 1970). Silver Centre was a particularly important camp and reports have estimated that more than $23,338,906 \mathrm{oz}$ of silver and $50,901,331 \mathrm{oz}$ of cobalt had been removed from this 
region by 1968 (McIlwaine 1970). Production continued to expand until around 1923, when it began to steadily decline into the 1930 s due to the drop in silver prices as a result of the stock market crash of 1929 (Anderson 1993). No mines are currently in operation in the region.

Over 443,888,906 oz of silver and 448,229,331 oz of cobalt were mined from the total Cobalt area between 1903 and 1968 (McIlwaine 1970; Thomson 1964). Using today's prices (\$21.12/ oz for Ag, and $\$ 16.33 / \mathrm{oz}$ for $\mathrm{Co}$, in $\mathrm{CAD})$, the dollar value for this amount of silver and cobalt would be over $\$ 16$ billion CAD. While obviously economically important, the Cobalt site was fundamental to the establishment of the Canadian mining workforce as much of the desired ore was located close to the surface. This allowed many novice labourers to develop their skills and techniques in the Cobalt region, especially as the mines grew deeper, before continuing elsewhere, such as to Timmins and Kirkland Lake where gold was later discovered (Dumaresq 2009). As a result, the region has been credited with the legacy of where Canadian financiers first invested in local mining, paving the way for future expansions of resource extraction in the country (Smith 1986).

While mining activities in the region produced a lot of wealth it also left behind a legacy of environmental damage. Upon the initial discovery of silver in the region, the town of Cobalt grew to several thousand inhabitants within a single decade (Baldwin \& Duke 2005). This rapid population growth resulted in significant environmental degradation due to poor urban planning, unrestricted mining activities and the draining of Cobalt Lake - the town's original source of drinking water (Baldwin \& Duke 2005). However, the most insidious form of mining-related contamination is the waste arsenic produced alongside the extraction of silver-containing ore from the region. While over 443 million ounces of silver was extracted from the Cobalt region, almost 2.5 billion ounces of arsenic was also produced in tandem, with much of it still present on 
the landscape to this day (Thomson 1964). This arsenic was extracted alongside the desired silver-containing ore, but was not deemed commercially useful and therefore needed to be disposed of. As a result, any extracted arsenic that remained in the silt- to sand-sized tailings and larger waste rock material, was ultimately dumped into, or left on the catchment of, nearby lakes. As mining in the region took place in a time before environmental regulations, the companies responsible for this waste were not required to clean it up after the cessation of their operations. Therefore, many of the impacted waterbodies in the Cobalt region remain highly contaminated with arsenic to this day (Sprague et al. 2016).

\section{3: Previous Work in Cobalt}

Due to its significance in Canada's mining history, the Cobalt region has recently become an area of interest for environmental researchers. Some of the most recent work completed in the region has focused on establishing the historical geochemical baseline of the area, as well as investigating the differences between historical and present day sediment geochemistry (Sprague \& Vermaire 2018). Changes in arsenic concentrations are of particular interest due to its high abundance in the region and known toxicity. Sprague \& Vermaire (2018) determined that uncontaminated lakes in the region had a median arsenic concentration in lake sediments of 2.6 $\mathrm{mg} / \mathrm{kg}$, well below the $17 \mathrm{mg} / \mathrm{kg}$ CCME's probable effect level guideline for the protection of aquatic life. Sediments from lakes where the geology of their catchment contained Nipissing Diabase were found to have the highest natural background arsenic concentrations, suggesting that bedrock geology of the Cobalt region is an important control on the sediment geochemistry of lakes located in the area.

Another study conducted in 2016 investigated the impacts of arsenic introduced by century-old mine tailings which had migrated into previously uncontaminated waterbodies in the 
region (Sprague et al. 2016). Arsenic levels in surface water samples taken from systems exposed to these metal-rich tailings were found to be as high as 240 times the regulatory standard for arsenic in soil (17 mg/kg), and 268 times the CCME surface water guideline for the protection of aquatic life $(5 \mu \mathrm{g} / \mathrm{L})$ (Sprague et al. 2016). At sites where tailings have remained relatively undisturbed, Sprague et al. (2016) suggested that redox conditions have been an important control on the behaviour of arsenic and other mining-related heavy metals. This was evident in portions of the tailings located above the water table, as these regions were highly enriched with metals, particularly within clay layers, where some samples were found with arsenic concentrations as high as 4,330 $\mathrm{mg} / \mathrm{kg}$ (Sprague et al. 2016).

Of the work currently available on the impacts of mining in the Cobalt region, much of it has been focused on the conversion of lakes into wetland systems due to the input of arsenic-rich mine tailings, and the subsequent geochemical interactions between changing redox conditions and the mobilization of contaminants (Kelly et al. 2007; Beauchemin \& Kwong 2006; Kwong et al. 2006). One such study by Kwong et al. (2006) examined wetlands in both Farr and Mill Creek near Cobalt in order to characterize the composition of mine tailings settled along the bottom of the drainage system, as well as to clarify some of the transformation and mobilization processes involved with arsenic. Using anionic exchange membranes, arsenic sorption isotherm, and desorption; chemical; and mineralogical analyses; the results of this research concluded that the submerged tailings in the system were likely acting as a source, rather than a sink, of arsenic (Kwong et al. 2006). This was due, in part, to the low concentrations of aluminum and iron $(<8 \%$ and $<6 \%$, respectively) in the tailings, as well as the fact that iron and manganese oxides made up only a small amount of the overall tailings composition (Kwong et al. 2006). 
Kwong et al. (2006) also found that dissolved phosphate and arsenate were competing with one another for available sorption sites, with phosphate sorption often dominating in the system. This result suggested that with continued input of phosphate into the system, arsenic release would be further propagated. The final finding of the study was that arsenic speciation in these creeks transformed rapidly depending on the prevailing redox conditions. In these systems, sedimentary arsenic found in more shallow areas was more likely to be subjected to a greater number of influences, such as oscillating saturation conditions due to seasonal, perennial flooding, and wetting and drying cycle controls (Kwong et al. 2006). Therefore, the best strategies for minimizing arsenic release in the region include approaches such as in depth analyses of the arsenic and redox conditions present, particularly when revegetating impacted areas as this technique requires inputs of fertilizers which may introduce more competitive phosphate into already vulnerable systems (Kwong et al. 2006).

Another study took place in 2007 and focused solely on the Farr Creek drainage basin in an attempt to characterize the biogeochemical interactions occurring within the system, and the effectiveness of the wetland at attenuating the metals introduced from the tailings (Kelly et al. 2007). Kelly et al. (2007) concluded that the wetland was relatively stable with the majority of metal(loid)s existing as precipitates, but that if a significant change were to occur, such as an increase in the amount of bioavailable organic substrate, a significant portion of the heavy metals, and arsenic, currently adsorbed to iron and manganese oxides could be released and become mobilized. This in turn would likely impact other geochemical processes regulating contaminant mobilization, such as increased activity of sulphur-reducing bacteria species (SRBs), and the amount of metals adsorbing to the introduced organic materials. Redox conditions, the presence of sulfides, microbes, iron and manganese oxides, and organic matter 
were all identified as being important controls on the geochemical interactions between metals and the environment in this particular wetland (Kelly et al. 2007).

While not a lot of work with bio-indicators has been done in the region, some researchers have looked at the behaviour and community composition of arcellacea (testate amobae) in and around Cobalt. In 1996, Patterson et al. determined that arcellacea could be used as proxies of both arsenic and mercury contamination in the Cobalt region, with distinct faunas being found in substrates labelled as contaminated, mine tailings, muddy, and diatom mud. However, they also observed that certain lake morphometrical parameters such as water flow, oxyen levels, and temperature also had a significant role in influencing arcellacean distribution in the area (Patterson et al. 1996). Reinhardt et al. (1998) followed up on this research and found that arcellaceans are good indicators of aquatic microenvironments, pollutants, and rates of remediation in previously contaminated lakes. The main conclusion of this study suggested that remediation of lakes in the Cobalt region which have been negatively impacted by historical mining activities should have their mine tailings buried naturally, or through the addition of an allochthonous sediment cap (Reinhardt et al. 1998). The most recent study on arcellacea in the Cobalt region found that their asexual reproduction has allowed for the creation of environmentally influenced "strains" or taxa, which are particularly useful in the identification of pollutated versus remediated lake system sites (Patterson \& Kumar 2000).

\section{4: Arsenic in the Environment}

Arsenic contamination in aquatic systems is a hazard of concern due to its negative human and environmental health impacts (CCME 2001). The main sources of arsenic in the environment include the weathering of rocks and soils, and anthropogenic inputs such as tailings 
and roaster emissions from gold and silver mines, wood preservatives, herbicides, pharmaceuticals, and glass manufacturing by-products, as well as coal-fired power plants (Wang \& Mulligan 2006; CCME 2001; Eisler 1988). Recent analyses of air, soil, sediment, water and biota indicate that arsenic inputs from anthropogenic sources have pushed many impacted sites past the accepted Interim Maximum Acceptable Concentration (IMAC) levels (Wang \& Mulligan 2006; Government of Canada 1993). In Canadian freshwater systems, natural arsenic concentrations are typically less than $2 \mu \mathrm{g} / \mathrm{L}$, however, areas which have been impacted by mining and other anthropogenic activities have seen concentrations as high as 19,800 $\mu \mathrm{g} / \mathrm{L}$ (CPHA 1977). A recent study of 211 near-surface sediment samples taken from the Yellowknife, Northwest Territories region, an area contaminated with arsenic through gold mining, found that most of the lakes sampled also had surface water arsenic concentrations exceeding the CCME objective for the protection of aquatic life ( $5 \mu \mathrm{g} / \mathrm{L}$ ) (Galloway et al. 2015). Of these samples, 71\% ( $\mathrm{n}=149)$ were also found to be over the CCME's Interim Freshwater Sediment Quality Guideline $(5.9 \mathrm{mg} / \mathrm{kg})$, and $54 \%(\mathrm{n}=114)$ were found to contain concentrations exceeding the CCME Probable Effect Level (17 mg/kg) (Galloway et al. 2015).

Arsenic (As) is a naturally occurring metalloid, and can be found in the environment as both organic and inorganic species (Eisler 1988). In natural systems, it typically exists in one of the following four oxidative states: $\mathrm{As}(-\mathrm{III}), \mathrm{As}(0), \mathrm{As}(\mathrm{III})$, and $\mathrm{As}(\mathrm{V})$. However, when studying the impacts of arsenic in the environment, only $\mathrm{As}(\mathrm{III})$ and $\mathrm{As}(\mathrm{V})$ are of concern as they appear most frequently in nature (Wright \& Welbourn 2002; Dumaresq 1993). These two arsenic species are commonly referred to as arsenite and arsenate, respectively. The degree of arsenic toxicity and bioavailability depends largely on its form, and can be significantly modified by a variety of biotic and abiotic factors. Inorganic arsenic is typically considered more toxic than 
organic compounds, and trivalent species are thought to be more toxic than pentavalent species (Eisler 1988). However, arsenic can change speciation depending on the different chemical conditions of the ecosystem, and some researchers have argued that arsenate is the more toxic form of arsenic due to how chemically similar it is to phosphate (Landner 1998). The generally accepted toxicity of arsenic from most to least toxic is as follows: arsines $>$ inorganic As(III) $>$ organic As(III) > inorganic As $(\mathrm{V})>$ organic As $(\mathrm{V})>$ arsonium $>$ elemental As (Eisler, 1988). In aerobic freshwater systems, like shallow lakes and rivers, arsenate $(\mathrm{As}(\mathrm{V}))$ tends to be the dominant form of arsenic in surface water (Landner 1998).

Arsenic undergoes many post-depositional sedimentary processes such as remobilization, changes in speciation, and the formation of new oxide compounds. Existing as a dissolved ionic species in lakes, arsenic is frequently adsorbed onto or co-precipitated with iron and manganese oxyhydroxides (Baird \& Cann 2012). While the mechanisms driving the release and uptake of arsenic by sediments are not fully understood, it is clear that when the hypolimnion is oxygenated, arsenic is recycled with iron $(\mathrm{Fe})$ or manganese $(\mathrm{Mn})$ oxyhydroxides (Couture et al. 2010). When arsenic becomes bound to one of these oxyhydroxides, it forms insoluble precipitates, which greatly reduce arsenic's mobility (Nikolaidis et al. 2004). However, under anaerobic conditions, these insoluble oxides may be reduced to their more soluble (Fe(II) or $\mathrm{Mn}(\mathrm{II})$ ) oxide forms, which allows for the release of arsenic, causing it to become remobilized above the sediment-water interface. Arsenic tends to be found in the As(V) state when it is bound to oxyhydroxides, and becomes reduced to As(III) upon the dissolution of these particulates (Baird \& Cann 2012). The biogeochemical recycling of arsenic in aquatic systems therefore appears to be closely tied to the presence of these oxyhydroxides and the amount of dissolved oxygen available. Organic matter and carbonates have also been shown to host prime 
adsorption sites for arsenic and other metal(loid) uptakes (Kelly et al. 2007). Under aerobic conditions, arsenate tends to be the most common form of arsenic, with anaerobic conditions favouring higher arsenite concentrations.

Arsenic also undergoes microbiological oxidation, reduction, and methylation processes in aquatic systems (Eisler 1988). Bacterial species which exist in anaerobic environments appear to be the most successful at reducing arsenic species found in lake sediments and therefore, causing the metalloid to become remobilized (Islam et al. 2004). Microorganisms play a defining role in catalyzing the redox transformations, which ultimately control arsenic mobility (Orelamnd \& Stol 2003). Anaerobic metal-reducing bacteria, in particular, are able to reduce arsenate to arsenite, with $\mathrm{Fe}(\mathrm{III})$-reducing bacteria focusing specifically on the $\mathrm{Fe}(\mathrm{III})$ species and its use as an electron acceptor. The formation of toxic, mobile arsenite is therefore dependent on the availability of electron donors in the sediment (Islam et al. 2004). A study of microbes in contaminated wetlands in the Cobalt region also found that the acid-producing bacteria typical of aquatic environments impacted by mine tailings existed at a similar population size to other bacteria-types in the system (Kelly et al. 2007). This indicates that the alkaline conditions produced by the mine tailings in the Cobalt system have helped to neutralize the acids produced by these bacteria through the dissolution of carbonate minerals. The presence of metal-reducing and -oxidizing bacteria, in addition to $\mathrm{pH}$, are both important controls on the speciation and subsequent (re)mobilization of arsenic in freshwater systems, particularly in sediment (Andrade et al. 2010; EPA 1985).

Depending on the prevailing redox conditions, sediments can be either sinks or sources of arsenic, but typically have high concentrations due to the interactions between anionic arsenates and hydrous Fe and Mn oxides (Aggett \& Roberts 1986). Arsenic binds to clays, organic matter, 
and certain other sediment materials (Cullen \& Reimer 1989). Arsenic concentration is also influenced by sediment grain size and is more strongly associated with materials which have smaller grain sizes, such as clays (Sprague et al. 2016). Sediment grain size is one of the most important environmental controls of arsenic and other heavy metal(loid)s sorption due to its greater specific surface area, and the role that clays, organic matter, and $\mathrm{Fe} / \mathrm{Mn} / \mathrm{Al}$ oxides play in forming fine-sized aggregates (Yao et al. 2015; Ljung et al. 2006; Cai et al. 2002; Semlali et al. 2001). More specifically, the association between arsenic and clay is likely due to the mechanism of cation bridging by calcium. Calcium is an alkaline metal, which is highly abundant in natural water bodies and can be further introduced from mine tailings (Sprague et al. 2016). Once adsorbed to sediment, the two most important controls of vertical arsenic movement through sediments, and therefore potential for remobilization into the water column, are surface binding and intra-particle/matrix diffusion (Nikolaidis et al. 2004). Surface binding occurs when arsenic is adsorbed onto the surface of the sediment matrix until equilibrium is achieved, typically occurring quite rapidly. This is a linear relationship, and is described by the following equation:

$$
C_{p}=\frac{C_{i m}}{K_{d}}
$$

where, $C_{p}$ represents the aqueous arsenic concentration found in the pores of the sediment matrix, $C_{i m}$ is the arsenic concentration in the sediment matrix of the pore, and $K_{d}$ is the sediment-parition coefficient (Nikolaidis et al. 2004). Intra-particle/ matrix diffusion is related to the gradient of arsenic concentration in a water body compared to the amount on the surface of the underlying sediment pores (Nikolaidis et al. 2004). Other important controls of arsenic's speciation and mobility include flow velocity, vegetation, temperature, concentration, biological 
activity, and location in the water column (Sprague et al. 2016; Thienpont et al. 2016; Nikolaidisa et al. 2004).

Many of these environmental controls are also important in determining the bioavailability of arsenic in a system, which in turn, is responsible for its overall toxicity. The bioavailability of metals and metalloids is the extent to which they are able to adsorb onto or into, as well as across biological membranes of exposed organsisms, with the potential for distribution, metabolism, elimination, and bioaccumulation (McGeer et al. 2004). Bioavailability and solubility are important factors in the overall concentration of arsenic in aquatic systems, and are dependent on a variety of parameters including the presence and concentration of hydroxides, clay content, redox potential, and $\mathrm{pH}$ (Smith et al. 1999). Inorganic arsenic species tend to be more bioavailable and toxic than organo-arsenic species (McGeer et al. 2004). Sediments hosting materials with smaller grain sizes may end up localizing arsenic inside minute pores $(<100 \mathrm{~nm})$ due to the same sorption mechanisms discussed earlier, which can reduce the overall bioavailability of the arsenic present (Alexander 2000). The solubility and bioavailability of arsenic tends to decrease with time due to it becoming sequestered into the sediment matrix (Turpeinen et al. 2002; Alexander 2000). However, arsenic which is no longer available for biological uptake in one system may still pose a risk through the introduction to new and different environmental conditions, as this may lead to remobilization, and therefore, uptake of a variety of species of arsenic (Turpeinen et al. 2002). This is particularly important when considering the risks of migrating arsenic, and other heavy metal(loid)s, into previously uncontaminated systems. The presence of organic matter, phosphorous, oxygen, and microbial activity can all lead to changes in arsenic mobility, bioavailability, and ultimately, toxicity.

Phosphorous is of particular importance when determining the overall toxicity of arsenic 
in an aquatic system, as the two chemicals are positioned relatively close together in the periodic table, and therefore, have been found to behave similarly to one another. Belonging to the same group, both elements have an $s^{2} p^{3}$ electron configuration in their valence shells, which means that they have similar oxyanion forms (i.e., $\mathrm{AsO}_{3}{ }^{3-}$ and $\mathrm{AsO}_{4}{ }^{3-}, \mathrm{PO}_{3}{ }^{3-}$ and $\mathrm{PO}_{4}{ }^{3-}$ ) (Baird \& Cann 2012). As a result, arsenic and phosphorous tend to cohabitate similar spaces often interacting and competing with one another for sorption sites (Reuther 1992). Because phosphorous is an important limiting nutrient in the overall productivity of freshwater systems, its relationship with arsenic is thought to be one of the main drivers of arsenic's ecotoxicity (Baird \& Cann 2012; Landner 1998). In systems with low phosphorous concentrations, the introduction of even a small amount of arsenic can lead to significant environmental impacts, whereas systems with moderate to high phosphorous concentrations are typically more tolerant of arsenic inputs (Landner 1998). The substitution of phosphorous by arsenic at a cell's surface, and subsequent phosphorylation reactions which occur once arsenic is inside the cell, are thought to be the main modes of action for arsenic toxicity in single celled aquatic organisms such as algae (Landner 1998). Despite the known potential for arsenic ecotoxicity, relatively little is known about the direct impacts the metalloid has on key organisms in aquatic ecosystems.

\section{5: Bio-indicators}

The field of paleolimnology, in part, investigates the long-term impacts of contaminants like arsenic in aquatic ecosystems by reconstructing past environmental conditions through the use of chemical, physical, and biological proxies. Biological proxies are used to determine ecological responses to known or potential changes in lake systems. Proxy selection is typically decided by how sensitive to environmental change, widespread, and taxonomically resolved a biological indicator is to determining baseline, or reference, conditions in an area of interest 
(Dixit et al. 1992). Diatoms, cladocera, and chironomids represent three commonly used biological proxies in paleolimnology due to how well their subfossils preserve in lake sediments, in addition to their well-defined sensitivities to environmental stressors. The growing body of literature surrounding biological proxies and their potential range of optima regarding exposure to certain contaminants allows researchers to have a better understanding of how both historical and present day contamination events impact aquatic ecosystems.

\subsection{1: Diatoms}

Diatoms are single-celled algae belonging to the algal class Bacillariophyceae. They have distinctive cell walls, which are composed primarily of silica $\left(\mathrm{SiO}_{2}\right)$. Diatom cell walls are made up of two halves known as valves, which are held together by girdle bands (Dixit et al. 1992). Diatoms are a common choice for paleolimnology studies because they have rapid replication rates, short lifespans, high species diversity and identifiable environmental contaminant sensitivities (Dixit et al. 1992). Different species of diatoms have relatively unique and narrow optima and tolerances to a variety of environmental variables, which allows for the identification of environmental change to a high degree of certainty (Dixit et al. 1992). Therefore, changes in species assemblages through time and space, as well as the identification of species of known tolerance to present environmental variables, can be observed in order to explore the magnitude and trajectory of potential environmental change. Diatoms have been used extensively in the study of the impacts of eutrophication, acidification, climate warming, and salinification (Dixit et al. 1992).

\subsection{2: Zooplankton}

Zooplankton are heterotrophic plankton which range in size from micro- to macroscopic and are highly abundant in freshwater systems. Zooplankton employed as bio-indicators are 
typically small in size, have simple body structures, use parthenogenetic reproduction, have high fecundity, and short life-cycles (Moreira et al. 2015; Snell \& Janssen 1995). The most common type of zooplankton used as bio-indicators are cladocera, which are a group of microscopic aquatic organisms (typically smaller than $1 \mathrm{~mm}$ ) belonging to the branchiopod crustaceans. Cladocera can be found in almost every known freshwater habitat ranging from small puddles to large lakes (Korhola \& Rautio 2006). Cladocera are important contributors to aquatic ecosystems as they are grazers of algae, detritus, and various heterotrophs (Nilssen 1978; Edmondson 1957), regenerate nutrients for primary producers and bacteria (Järvinen \& Salonen 1998), and provide a food source for fish and other organisms (Tolonen 1998; Dodson \& Hanazato 1995; Black 1993). Some cladocera species are herbivores, while others prey upon smaller organisms, such as other, smaller zooplankton (Korhola \& Rautio 2006). Cladocera are popular bio-indicators in paleolimnology as they are one of the most commonly found subfossils in sedimentary deposits (Korhola \& Rautio 2006). Their shells, head-shields, post-abdomens and claws can all be used to identify environmental changes within freshwater systems. They have been particularly effective in the identification of climate change, trophic oscillations, acidification, and water level changes (Korhola \& Rautio 2006).

\subsection{3: Chironomids}

Chironomidae (Insecta: Diptera) are non-biting midges, which live in aquatic environments until they are adults (Kranzfelder et al. 2015). These bottom-dwelling freshwater macroinvertebrates are extremely diverse, with only 5,000 of the suspected 20,000 species currently identified (Ferrington 2008). Chironomids are therefore useful in environmental monitoring as their high diversity offers a wide range of tolerances to different aquatic contaminants. Chironomids are the most abundant and widespread benthic macroinvertebrate in 
freshwater systems, typically accounting for $50 \%$ or more of the total community (Ferrington et al. 2008; Armitage 1995). As a result, chironomids are one of the most widely used bioindicators in both paleolimnology and ecotoxicology research (Greffard et al. 2012; Jeyasingham \& Ling 2000). Chironomid sub-fossils found in sediments reflect changes to community structures through time, and can therefore be used to infer the combined physical, chemical and biological characteristics of the aquatic system of interest (Greffard et al. 2012; Broderson \& Quinlan 2006; Walker 2001).

There are four lifecycle stages of chironomids - egg, larva, pupa, and adult (Kranzfelder et al. 2015). Adult females lay their eggs on the surface of waterbodies, where they begin to sink to the bottom, and typically hatch on the surface of sediments within a few days to weeks. Once hatched, the larvae burrow into the sediment, constructing a series of tubes where they live and feed until they have developed into pupae. Once in the pupa stage, individuals swim to the water's surface until they emerge as adults from their pupal exuviae (Kranzfelder et al. 2015). It is therefore generally accepted that earlier life stages are more sensitive to the effects of pollution, as this is when they are exposed to contaminated sediments. This provides researchers with valuable insight into how the early onset of pollution in aquatic systems impacts more vulnerable aspects of the ecosystem (Jeyasingham \& Ling 2000). As a result, paleolimnological and ecotoxicological data tends to focus on the larval stage of chironomids.

\section{6: Biological Response to Short-term Arsenic Exposure}

In the environment arsenic is taken up by plants through their roots and leaves, and animals can be exposed to arsenic through ingestion, inhalation, or permeation of skin and mucous membranes (Eisler 1988). Arsenic can bio-accumulate in exposed organisms, but it does not bio-magnify through the food chain (CCREM 2003; Eisler 1988). While bio-magnification 
may not be a concern, bottom-feeding fish will, on average, accumulate higher arsenic concentrations than fish living in pelagic zones (CPHA 1977). Species, age, arsenic concentration, and water temperature are all important controls for the degree to which arsenic may bio-accumulate in an organism (U.S. EPA 1980).

While not a lot is currently known about the long-term impacts of arsenic in the environment, ecotoxicological data from short-term, lab-based experimental research are available for select species of vertebrates, invertebrates, and plants (Table 2-1). In general, plants appear to be an order of magnitude more sensitive to arsenic than vertebrates and invertebrates (CCME 1997). While some tested fish species ranged in their tolerances of arsenic from $550 \mu \mathrm{g} / \mathrm{L}$ (28-d LC 50 for Oncorhynchus mykiss [rainbow trout]) (Birge et al. 1979) to 970 $\mu \mathrm{g} / \mathrm{L}$ (7-d LOEC for Clarias batachus [catfish]) (Jana \& Sahana 1989), the green algae Scenedesmus obliquus, could only tolerate $50 \mu \mathrm{g} / \mathrm{L}$ under a 14-d EC50 (growth) test (Vocke et al. 1980). However, another algae in the same genus as S. obliquus, Scenedesmus quadricauda, was also exposed to arsenic and was found to withstand concentrations of up to $960 \mu \mathrm{g} / \mathrm{L}$ under a 20d VSUE test (very severe unfavourable effect) (Farfasova 1993). Both S. obliquus and $S$. quadricauda are unicellular green algae, and their wide range in arsenic tolerances showcases the need for better understanding of the long-term effects of arsenic in aquatic ecosystems, as well as highlights why certain biological proxies such as algae are important indicators of environmental response and change.

Certain studies have begun to investigate the impacts of different arsenic species on bioindicators in an attempt to better understand the routes of toxicity in aquatic organisms and ecosystems. He et al. (2009) ran three separate trials of arsenite, arsenate, and a combination of the two, using cladoceran culture medium and natural stream water on Daphnia carinata in order 
to investigate the relative toxicity of each arsenic species on the model organism. They found that arsenite was more toxic than arsenate, with the $\mathrm{LC}_{50}$ values determined to be $554,1,499$ and $692 \mu \mathrm{g} / \mathrm{L}$ for arsenite, arsenate, and the mixture of the two, respectively (He et al. 2009). They also noted that the difference between the $\mathrm{LC}_{50}$ values of arsenite and arsenate were higher in the tests which used natural stream water, as opposed to the cladoceran culture medium, with at least $25 \%$ of the initially spiked arsenite sample having been transformed to the less toxic arsenate within the 48-hour study period (He et al. 2009). This indicates that the toxicity of arsenite in the environment is likely microbially mediated. The $\mathrm{LC}_{50}$ of $D$. carinata was impacted by the presence of multiple arsenic species, indicating that arsenite and arsenate interact with one another in order to increase their overall toxicity (He et al. 2009).

\section{7: Paleo-ecotoxicology}

The results from in-lab studies like He et al. 2009 provide important insights into how single contaminants, like arsenic, may impact specifc targeted species. Unfortunately, conditions in the natural environment are much more complex, and as a result, the findings of traditional ecotoxicological studies may not always provide the necessary information required when trying to understand how certain contaminants behave, and therefore impact exposed ecosystems. More detailed information is therefore required in order to better understand the long-term effects of contaminants in the natural environment.

In an effort to bridge the gap between in-lab and in-situ research, a new approach combining the fields of traditional ecotoxicology and paleolimnology has been proposed: paleoecotoxicology. Paleo-ecotoxicology utilizes many of the methodologies currently used in paleolimnology in order to position traditional ecotoxicological testing frameworks over a longer 
period of time, and within natural ecosystem settings in order to better represent the increased complexity and multiple stressor exposure to bio-indicators of interest, particularly when compared to the results of laboratory studies (Korosi et al. 2017). Within this framework, lake sediment cores can be used as records of specific environmental contaminants, such as metals and persistent organic pollutants, and can therefore be thought of as the "dose/ stressor" record. Since sediment cores also preserve the fossils of bio-indicators used in both ecotoxicology and paleolimnology, they can also be used as the "response" record (Korosi et al. 2017). Paleoecotoxicological frameworks have been adopted in a variety of different environmental studies including the investigation of the impacts of acid rain (Battarbee et al. 2010; Uutala et al. 1994; Charles \& Whitehead 1986), resurrection ecology (Geerts et al. 2015; Frisch et al. 2014; Hairston et al. 1999), and, in a few cases, the long-term exposure of aquatic ecosystems to arsenic (Thienpont et al. 2016; Chen et al. 2015; Doig et al. 2015).

\section{8: Biological Response to Long-term Arsenic Exposure}

While the long-term environmental impacts of mining-related contamination in the Cobalt region remain unknown, some research has been done in other areas, which have been impacted by large inputs of industrially-sourced arsenic. Using the framework proposed in the previous section, it can be seen that the following studies have used a paleo-ecotoxicological perspective in their consideration of the long-term exposure of arsenic to each impacted ecosystem. Chen et al. (2015) investigated the impacts of arsenic contamination through time in two different lakes in southwest China (Yangzong and Datun Lake). Yangzong Lake was exposed to arsenic via an industrial tailings leak which resulted in an increase of arsenic concentration in surface water from $\sim 7.3 \mu \mathrm{g} / \mathrm{L}$ to $\sim 177 \mu \mathrm{g} / \mathrm{L}$ within a single year. This increase 
in arsenic and other environmental pollutants was followed by a 10-fold decline in the zooplankton population with daphniid and bosminid accumulation rates dropping to 70.1 individuals/cm/year in 2013. The second lake, Datun Lake, had been exposed to arsenic for a much longer period of time due to wastewater and mineral tailings inputs during flooding events starting in 1963. Arsenic concentrations in Datun Lake increased from $\sim 12.0 \mu \mathrm{g} / \mathrm{L}$ in 1990 to $\sim 1,140 \mu \mathrm{g} / \mathrm{L}$ in 2008 . Bosminids were particularly impacted in Datun Lake with an observed reduction of 1,164 individuals/cm/year in 1998 to 87.3 individuals/cm/year in 2013. Sedimentary diatom profiles also experienced a shift in assemblages in both systems, which followed arsenic and other environmental pollutant inputs closely (Chen et al. 2015).

A 2016 study examined the impacts of mining in Pocket Lake in Yellowknife, Northwest Territories, Canada, where it was observed that a $1700 \%$ increase in arsenic concentration in the sediment profile coincided with known historical mining activities in the Yellowknife region (Thienpont et al. 2016). This increase resulted in a peak of $30,000 \mathrm{mg} / \mathrm{kg}$ of arsenic in the sediment, which corresponded with synchronous changes in the biological community of the lake, including the near extirpation of cladocera and planktonic diatom taxa (Thienpont et al. 2016). Chironomids in Pocket Lake also experienced a dramatic shift in assemblage consistent with the increase in metal contamination (Thienpont et al. 2016). Despite the fact that mining in this area ceased decades ago, there was no indication that biological recovery in Pocket Lake had occurred (Thienpont et al. 2016). Both the Chen et al. (2015) and Thienpont et al. (2016) studies suggest that arsenic contamination can have impacts on aquatic ecosystems as many of the affected biological indicators used in these studies make up the bases of the food webs in these systems.

While not included in the proxies utilized in the Chen et al. (2015) and Thienpont et al. 
(2016) papers, another study in 2016 looked at the potential application of lacustrine arcellinina (testate amoebae) as bio-indicators of arsenic contamination near Giant Mine in Yellowknife, Northwest Territories (Nasser et al. 2016). Sixty-one surface sediment samples were collected from 59 lakes in the region, and using a cluster analysis (Q-R-mode) and detrended correspondence analysis (DCA), it was determined that three out of the five identified arcellininid assemblages were related to sedimentary arsenic concentration. Arsenic was found to have the greatest influence on arcellinina assemblage variance (10.7\%), with species indicative of stress conditions found to characterize samples with high arsenic concentrations, and difflugiid-dominated assemblages being more strongly correlated with lower arsenic concentrations (Nasser et al. 2016). Arcellinina were found to be sensitive to arsenic contamination in general, and therefore, represent a promising potential bio-indicator for future studies interested in the impacts of the metalloid in the environment (Nasser et al. 2016).

Although the Chen et al. (2015), Thienpont et al. (2016), and Nasser et al. (2016) studies have suggested that legacy contamination with arsenic and other metals can alter the ecology of a lake through time, a more recent study by Tenkouano et al. (2019) has suggested that it is the combination of different factors that is responsible for the changes observed in impacted biological community structures. Tenkouano et al. (2019) examined the impacts of gold mining in Moira Lake from the Deloro industrial site in Ontario, Canada by establishing a ${ }^{210} \mathrm{~Pb}$-dated sediment core record. Analyses of the core found that following the opening of the mine lake sediments became enriched with arsenic, cobalt, and nickel. Arsenate was found to be the dominant arsenic species in the record, with it being mostly hosted on iron oxides, but arsenite became more prevalent further down core due to low oxygen availability and, therefore, arsenic reducing processes (Tenkouano et al. 2019). Despite sediments having been clearly impacted by 
mining activities, biological production appeared to have been influenced by a variety of different factors, as opposed to just contamination (Tenkouano et al. 2019). No direct correlation with arsenic, cobalt, or nickel could be established with changes in cladoceran assemblage (Tenkouano et al. 2019). Chlorophyll- $a$ was also observed to increase again shortly after its initial decrease with the onset of industrial activities, and while still being subjugated to contamination inputs (Tenkouano et al. 2019). Nutrient enrichment and climate-related variables were identified as main drivers of the ecological shifts observed, and could potentially be more important than arsenic in this particular lake system (Tenkouano et al. 2019).

These conflicting findings identify the need for more research regarding the long-term exposure of aquatic ecosystems to arsenic. More specifically, it is necessary to attempt to isolate the impacts of arsenic from other environmental controls and contaminants, in order to better understand the role that it plays in community composition in these systems. Therefore, the main objective of this thesis was to identify the impacts, if any, that long-term arsenic exposure has had on aquatic environments in the Cobalt, Ontario, Canada region, by quantifying the responses of multi-trophic level bio-indicator community assemblage changes along a spatial gradient of arsenic contamination using a paleo-ecotoxiological approach. The lakes selected for this study were impacted by historical mining activities in and around the Cobalt region nearly a century ago, and have undergone little to no remediation. These sites have remained relatively undisturbed since the cessation of industrial activities in the region and therefore, represent important study sites for the long-term impacts of arsenic in the environment. 


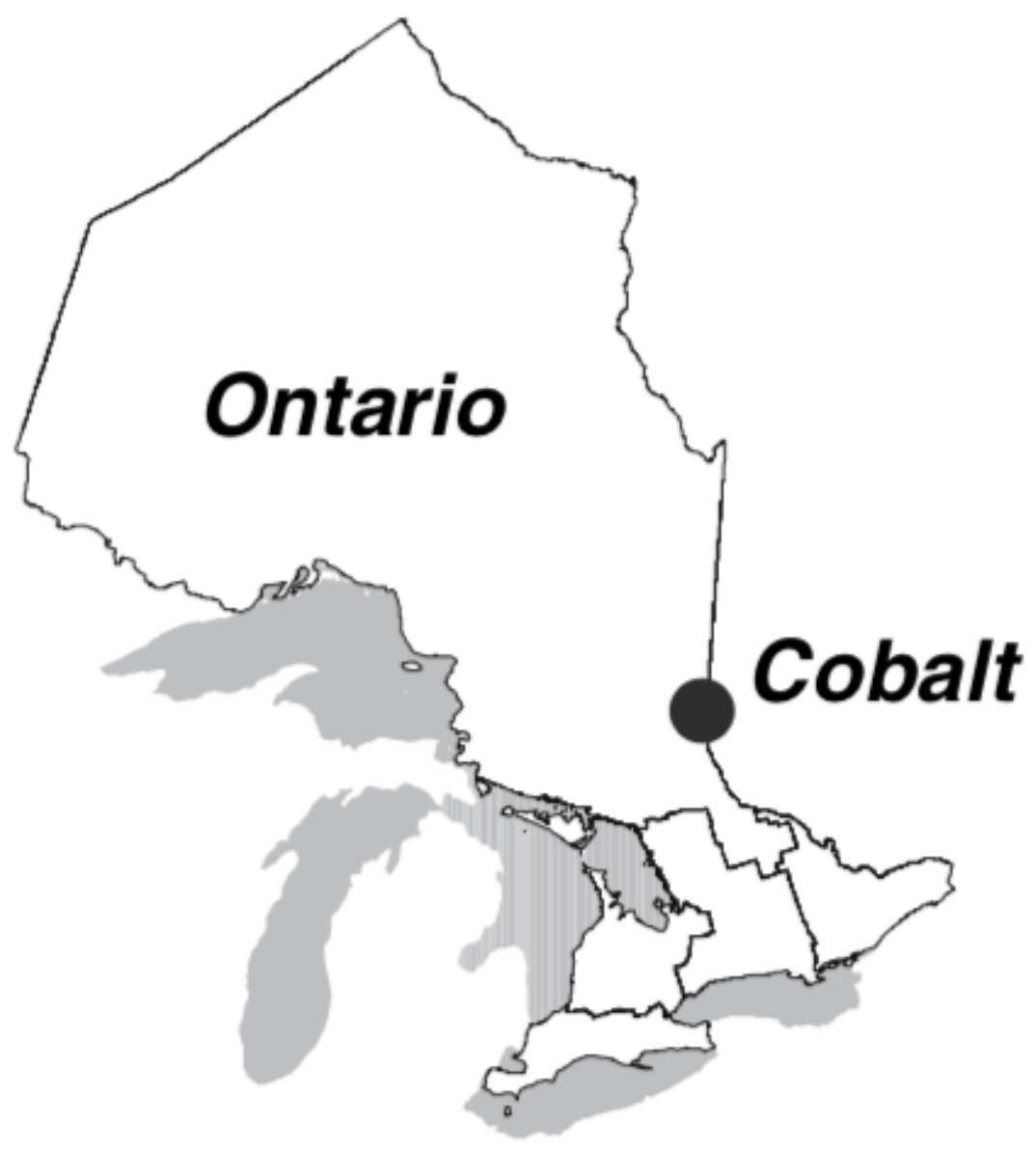

Figure 2-1: Map showing the location of Cobalt within the province of Ontario, Canada. Ontario has been divided into five regions (southern, southwestern, central, eastern, and northern). The Great Lakes are shown in light grey. Modified from Kelly et al. (2007). 
Table 2-1: Known arsenic toxicity data for freshwater organisms. Table modified from CCME 2001 and Eisler 1988.

\begin{tabular}{|c|c|c|c|c|c|c|c|}
\hline \multicolumn{2}{|c|}{$\begin{array}{c}\text { Organism } \\
\text { Type }\end{array}$} & Organism Species & $\begin{array}{l}\text { Arsenic } \\
\text { Species }\end{array}$ & $\begin{array}{c}\text { Toxicity } \\
\text { Endpoint }\end{array}$ & $\begin{array}{c}\text { Concentration } \\
(\mu \mathrm{g} / \mathrm{L})\end{array}$ & Details & Reference \\
\hline \multirow{7}{*}{\multicolumn{2}{|c|}{ 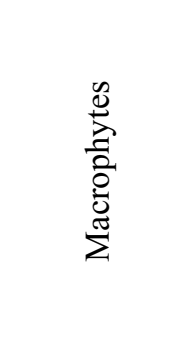 }} & Elodea candensis & As(III) & $28-\mathrm{d} \mathrm{IC} 50$ & 900 & & Brown \& Rattigan 1979 \\
\hline & & \multirow{3}{*}{ Lemna minor } & \multirow{2}{*}{ As(III) } & $7-\mathrm{d} \mathrm{EC}_{50}$ & 2,040 & & Naumann et al. 2007 \\
\hline & & & & $28-\mathrm{d} \mathrm{IC}_{50}$ & 150 & & Brown \& Rattigan 1979 \\
\hline & & & $\mathrm{As}(\mathrm{V})$ & $7-\mathrm{d} \mathrm{EC}_{50}$ & 8,180 & & Naumann et al. 2007 \\
\hline & & \multirow{3}{*}{ Lemna disperma } & As(III) & $7-\mathrm{d} \mathrm{EC}_{50}$ & 570 & & \multirow{3}{*}{ Rahman et al. 2014} \\
\hline & & & $\mathrm{As}(\mathrm{V})$ & 7-d EC 50 & 2,250 & & \\
\hline & & & DMA & $7-\mathrm{d} \mathrm{EC}_{50}$ & 55,840 & & \\
\hline \multirow{18}{*}{ 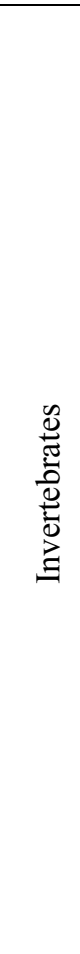 } & \multirow{18}{*}{$\frac{\mathscr{E}}{\mathbb{\infty}}$} & \multirow{4}{*}{ Champia parvula } & \multirow{3}{*}{$\mathrm{As}(\mathrm{III})$} & - & 65 & Normal sexual reproduction & \multirow{4}{*}{ Thursby \& Steele 1984} \\
\hline & & & & $\begin{array}{l}\text { No sexual } \\
\text { reproduction }\end{array}$ & 95 & & \\
\hline & & & & $\mathrm{LC}_{100}$ & 300 & & \\
\hline & & & $\mathrm{As}(\mathrm{V})$ & - & 10,000 & Normal growth, no sexual reproduction & \\
\hline & & \multirow{2}{*}{ Chlorella sp. strain CE-35 } & $\mathrm{As}(\mathrm{III})$ & 72-hr $\mathrm{EC}_{50}$ & 30,000 & & \multirow{2}{*}{ Rahman et al. 2014} \\
\hline & & & $\mathrm{As}(\mathrm{V})$ & 72-hr $\mathrm{EC}_{50}$ & 1,150 & & \\
\hline & & Plumaria elegans & As(III) & 18-hr treatment & 580 & $\begin{array}{l}\text { Arrested sporelling development } 7 \text { days post- } \\
\text { treatment }\end{array}$ & Sanders 1986 \\
\hline & & Skeletonema costatum & $\mathrm{As}(\mathrm{V})$ & Growth inhibition & 130 & & \multirow{2}{*}{ EPA 1985} \\
\hline & & Thallassiosira aestivalis & $\mathrm{As}(\mathrm{V})$ & - & 75 & Reduced chlorophyll- $a$ & \\
\hline & & Chlorella salina & As(III) & $72-\mathrm{hr} \mathrm{EC}_{50}$ & 2,700 & & Karadjova et al. 2008 \\
\hline & & \multirow{2}{*}{ Monoraphidium arcuantum } & $\mathrm{As}(\mathrm{III})$ & 72-hr IC 50 & 15,000 & & \multirow{2}{*}{ Levy et al. 2005} \\
\hline & & & $\mathrm{As}(\mathrm{V})$ & 72-hr IC 50 & 250 & & \\
\hline & & Scenedesmus obliquus & - & $14-\mathrm{d} \mathrm{EC}_{50}$ & 50 & & $\begin{array}{l}\text { Vocke et al. 1980, EPA } \\
1985\end{array}$ \\
\hline & & Scenedesmus quadricus & - & 20-d VSUE & 960 & & Fargasova 1993 \\
\hline & & Melosira granulata & - & $\mathrm{EC}_{50}$ & 75 & & \multirow{2}{*}{ Planas \& Healey 1978} \\
\hline & & Ochromonas vallesiaca & - & $\mathrm{EC}_{50}$ & 75 & & \\
\hline & & Ankistrodesmus falcatus & $\mathrm{As}(\mathrm{V})$ & $14-\mathrm{d} \mathrm{EC}_{50}$ & 260 & & \multirow[b]{2}{*}{ EPA 1985} \\
\hline & & Selenastrum capricornutum & $\mathrm{As}(\mathrm{V})$ & 4-d EC 50 & 690 & & \\
\hline
\end{tabular}




\begin{tabular}{|c|c|c|c|c|c|c|c|}
\hline 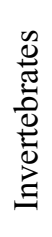 & 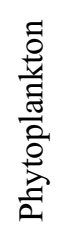 & - & $\mathrm{As}(\mathrm{V})$ & $4-d$ & 75 & Reduced biomass of populations & Thursby \& Steele 1984 \\
\hline \multirow{21}{*}{ 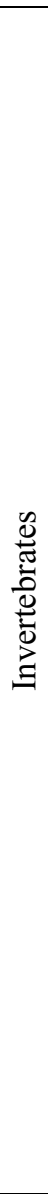 } & \multirow{21}{*}{ 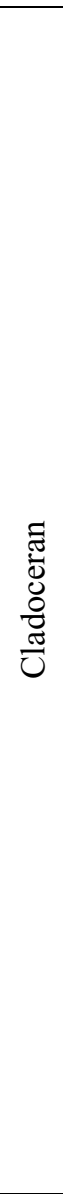 } & \multirow{16}{*}{ Daphnia magna } & \multirow{5}{*}{ As(III) } & $\begin{array}{c}21-\mathrm{d} \mathrm{EC}_{16} \\
\text { (reproduction) }\end{array}$ & 520 & & $\begin{array}{c}\text { Biesinger \& Christensen } \\
1972 \\
\end{array}$ \\
\hline & & & & $\begin{array}{c}\text { 96-hr IC } \mathrm{IC}_{50} \\
\text { (immobilization) }\end{array}$ & 1,500 & Starved & \multirow{2}{*}{ Lima et al. 1984} \\
\hline & & & & $\begin{array}{c}96-\mathrm{hr} \mathrm{IC}_{50} \\
\text { (immobilization) } \\
\end{array}$ & 4,340 & Fed & \\
\hline & & & & MATC $^{\mathrm{c}}$ & $630-1,320$ & & EPA 1985 \\
\hline & & & & $28-\mathrm{d} \mathrm{LC}_{5}$ & 960 & & Spehar et al. 1980 \\
\hline & & & \multirow{5}{*}{$\mathrm{As}(\mathrm{V})$} & $21-\mathrm{d} \mathrm{LC} 50$ & 5,800 & & Enserink et al. 1991 \\
\hline & & & & $48-\mathrm{hr}$ & 4,350 & & Valenti et al. 2005 \\
\hline & & & & $\begin{array}{l}\text { Reproductive } \\
\text { impairment of } 16 \% \\
\text { in } 3 \text { weeks }\end{array}$ & 520 & & EPA 1985 \\
\hline & & & & $28-\mathrm{d} \mathrm{LC}_{5}$ & 930 & Maximum BCF of $219 \mathrm{X}$ & Spehar et al. 1980 \\
\hline & & & & 96-hr LC 50 & 7,400 & & EPA 1980 \\
\hline & & & DSMA & $28-\mathrm{d} \mathrm{LC}_{0}$ & 830 & & \multirow{2}{*}{ Spehar et al. 1980} \\
\hline & & & SDMA & $28-\mathrm{d} \mathrm{LC} 0$ & 1,100 & & \\
\hline & & & \multirow{4}{*}{ Total } & - & 1,000 & $18 \%$ decrease in body weight in 3 weeks & \multirow{4}{*}{ NRCC 1978} \\
\hline & & & & - & 1,400 & $50 \%$ reproductive impairment in 3 weeks & \\
\hline & & & & $21-\mathrm{d} \mathrm{LC}_{50}$ & 2,800 & & \\
\hline & & & & $\begin{array}{c}\text { 21-d IC } \text { IC }_{50} \\
\text { (immobilization) }\end{array}$ & $4,300-7,500$ & & \\
\hline & & \multirow{4}{*}{ Daphnia pulex } & \multirow{3}{*}{ As(III) } & 96-hr LC 50 & 1,300 & & EPA 1980, EPA 1985 \\
\hline & & & & $48-\mathrm{hr} \mathrm{EC}_{50}$ & 3,000 & & Johnson \& Finley 1980 \\
\hline & & & & 72-hr IC 50 & 2,500 & & Shaw et al. 2007 \\
\hline & & & $\mathrm{As}(\mathrm{V})$ & $\begin{array}{c}48-\mathrm{hr} \mathrm{IC}_{50} \\
\text { (immobilization) }\end{array}$ & 49,600 & & Passino \& Novak, 1984 \\
\hline & & Cyclops vernalis & - & $14-\mathrm{d} \mathrm{EC}_{20}$ & 320 & & Borgmann et al. 1980 \\
\hline
\end{tabular}




\begin{tabular}{|c|c|c|c|c|c|c|c|}
\hline \multirow[b]{20}{*}{$\neg \approx A$} & & Bosmina longirostris & - & $\begin{array}{c}\text { 96-hr IC } \mathrm{IC}_{50} \\
\text { (immobilization) }\end{array}$ & 850 & & Passino \& Novak 1984 \\
\hline & & \multirow{8}{*}{ Gammarus pseudolimnaeus } & - & $7-\mathrm{d} \mathrm{LC}_{80}$ & 960 & & Spehar et al. 1980 \\
\hline & & & & $\begin{array}{c}\text { 96-hr IC } \mathrm{IC}_{50} \\
\text { (immobilization) }\end{array}$ & 870 & & Lima et al. 1984 \\
\hline & & & As(III) & $28-\mathrm{d} \mathrm{LC} 20$ & 88 & & \multirow{6}{*}{ Spehar et al. 1980} \\
\hline & & & & $28-d L_{100}$ & 960 & & \\
\hline & & & $\operatorname{As}(\mathrm{V})$ & $28-\mathrm{d} \mathrm{LC}_{20}$ & 970 & No accumulations & \\
\hline & & & \multirow{2}{*}{ DSMA } & $28-\mathrm{d} \mathrm{LC}_{10}$ & 86 & & \\
\hline & & & & $28-\mathrm{d} \mathrm{LC}_{40}$ & 970 & & \\
\hline & & & SDMA & $28-\mathrm{d} \mathrm{LC}_{0}$ & 850 & & \\
\hline & & \multirow{4}{*}{ Ceriodapnia dubia } & - & $\begin{array}{c}\text { 7-d LOEC } \\
\text { (immobilization) }\end{array}$ & 1000 & & Spehar \& Fiant 1986 \\
\hline & & & As(III) & $48-\mathrm{hr} \mathrm{EC}_{50}$ & 1,580 & & \multirow{3}{*}{ Rahman et al. 2014} \\
\hline & & & $\operatorname{As}(\mathrm{V})$ & $48-\mathrm{hr} \mathrm{EC} 50$ & 1,720 & & \\
\hline & & & DMA & $48-\mathrm{hr} \mathrm{EC}_{50}$ & 5,910 & & \\
\hline & & \multirow{5}{*}{ Daphnia carinata } & \multirow{2}{*}{ As(III) } & $48-\mathrm{hr} \mathrm{LC}_{50}$ & 554 & Growth medium & \multirow{5}{*}{ He et al. 2008} \\
\hline & & & & $48-\mathrm{hr} \mathrm{LC}_{50}$ & 780 & Natural water & \\
\hline & & & \multirow{2}{*}{$\operatorname{As}(\mathrm{V})$} & $48-\mathrm{hr} \mathrm{LC} \mathrm{LC}_{50}$ & 1,499 & Growth medium & \\
\hline & & & & 48-hr $\mathrm{LC}_{50}$ & 880 & Natural water & \\
\hline & & & $\begin{array}{c}\mathrm{As}(\mathrm{III})+ \\
\mathrm{As}(\mathrm{V}) \\
\end{array}$ & $48-\mathrm{hr} \mathrm{LC}_{50}$ & 692 & & \\
\hline & & Simocephalus serrulatus & $\mathrm{As}(\mathrm{III})$ & 96-hr $\mathrm{LC}_{50}$ & 810 & & EPA 1985 \\
\hline & No & - & As(III) & - & 400 & No effect & NRCC 1978 \\
\hline
\end{tabular}




\begin{tabular}{|c|c|c|c|c|c|c|c|}
\hline & & & $\mathrm{As}(\mathrm{V})$ & - & 1,200 & Population reduction & NRCC 1978 \\
\hline \multirow{5}{*}{ 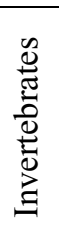 } & \multirow{5}{*}{ 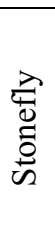 } & Pteronarcys californica & $\mathrm{As}(\mathrm{III})$ & 96-hr LC $\mathrm{LC}_{50}$ & 38,000 & & Johnson \& Finley 1980 \\
\hline & & \multirow{4}{*}{ Pteronarcys dorsata } & $\mathrm{As}(\mathrm{III})$ & $28-\mathrm{d} \mathrm{LC}_{0}$ & 960 & & \multirow{4}{*}{ Spehar et al. 1980} \\
\hline & & & $\mathrm{As}(\mathrm{V})$ & $28-\mathrm{d} \mathrm{LC}_{20}$ & 970 & Maximum BCF of 131X & \\
\hline & & & DSMA & $28-\mathrm{d} \mathrm{LC} \mathrm{C}_{0}$ & 970 & & \\
\hline & & & SDMA & 28-d LC & 850 & & \\
\hline \multirow{6}{*}{ 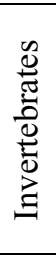 } & \multirow{6}{*}{ 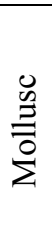 } & Corbicula fluminea & As(III) & 96-hr LC $\mathrm{LC}_{50}$ & 20,740 & & Liao et al. 2008 \\
\hline & & \multirow{5}{*}{ Helisoma campanulata } & $\mathrm{As}(\mathrm{III})$ & $28-\mathrm{d} \mathrm{LC}_{10}$ & 960 & & \multirow{5}{*}{ Spehar et al. 1980} \\
\hline & & & $\mathrm{As}(\mathrm{V})$ & $28-\mathrm{d} \mathrm{LC}_{0}$ & 970 & Maximum BCF of 99X & \\
\hline & & & DSMA & 28-d LC 0 & 970 & & \\
\hline & & & \multirow{2}{*}{ SDMA } & $28-\mathrm{d} \mathrm{LC}_{0}$ & 85 & & \\
\hline & & & & $28-\mathrm{d} \mathrm{LC}_{32}$ & 85 & & \\
\hline \multirow{10}{*}{ 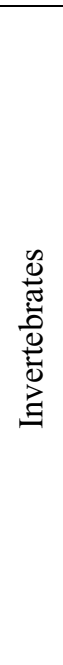 } & \multirow{10}{*}{$\frac{\sqrt{n}}{12}$} & Oncorhynchus mykiss & - & $28-\mathrm{d} \mathrm{LC}_{50}$ & 550 & & Birge et al. 1979 \\
\hline & & \multirow[b]{2}{*}{ Anabas testudineus } & & 7-d LOEC & 500 & & \multirow[b]{2}{*}{ Jana \& Sahana 1989} \\
\hline & & & - & $\begin{array}{l}\text { 72-hr LOEC } \\
\text { (survival) }\end{array}$ & 970 & & \\
\hline & & Clarias batrachus & - & 7-d LOEC & 970 & & Jana \& Sahana 1989 \\
\hline & & Ictalurus punctatus & $\mathrm{As}(\mathrm{III})$ & 96-hr LC 50 & 25,900 & & NAS 1977 \\
\hline & & \multirow{2}{*}{ Jordanella floridae } & \multirow{2}{*}{ As(III) } & 96-hr LC $\mathrm{LC}_{50}$ & 14,400 & & Lima et al. 1984 \\
\hline & & & & MATC $^{\mathrm{c}}$ & $2,100-4,100$ & & EPA 1985 \\
\hline & & \multirow{3}{*}{ Lepomis macrochirus } & \multirow{3}{*}{ As(III) } & 16-wk treatment & 690 & Juveniles; reduced survival & EPA 1980, EPA 1985 \\
\hline & & & & $\begin{array}{c}\text { 16-wk (weekly } \\
\text { treatments) }\end{array}$ & 690 & Adults; histopathology & EPA 1980 \\
\hline & & & & 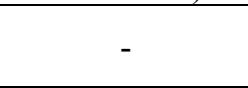 & 4,000 & $\begin{array}{l}\text { Population reduction of } 42 \% \text { after several } \\
\text { monthly applications }\end{array}$ & NAS 1977 \\
\hline
\end{tabular}




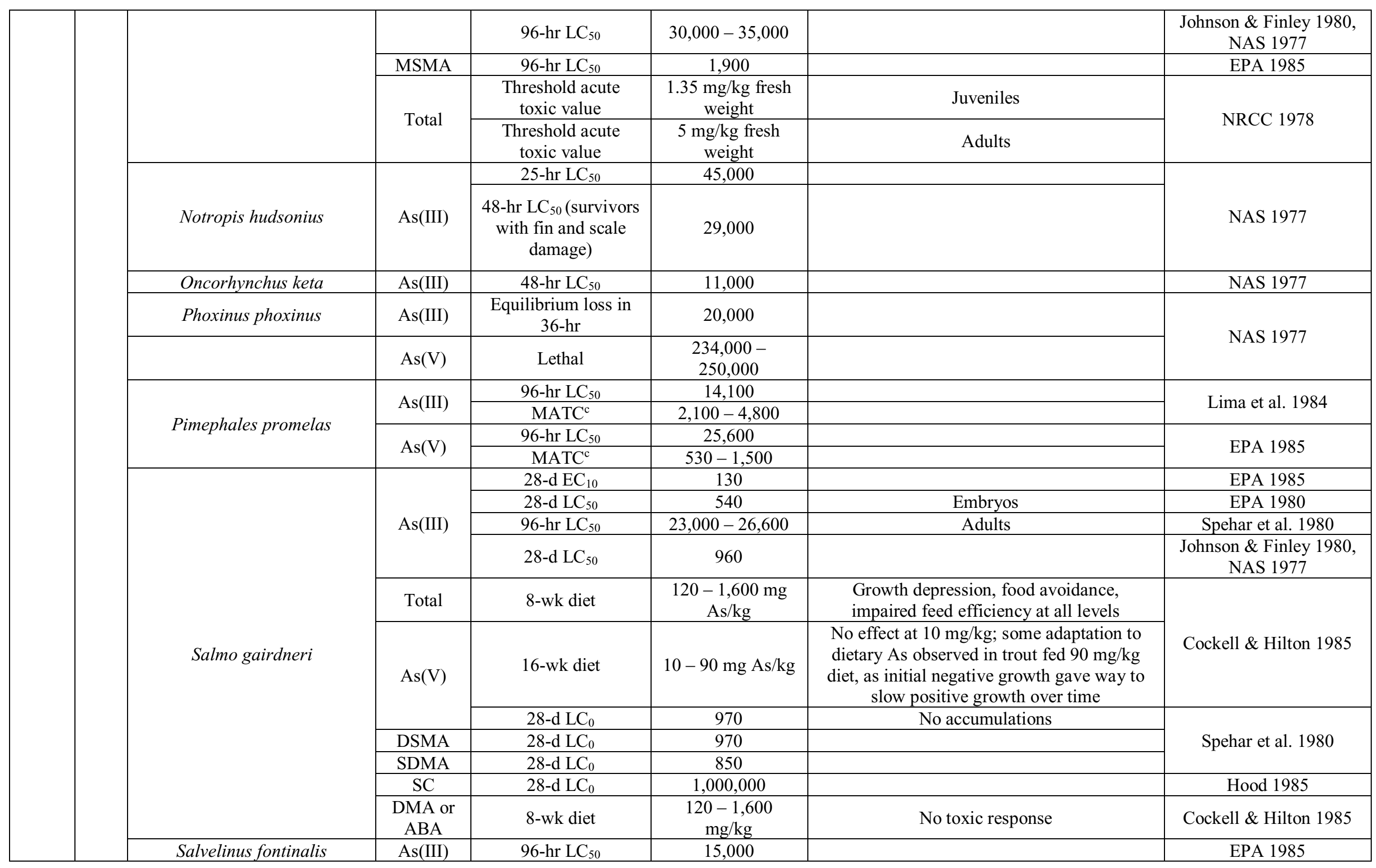




\begin{tabular}{|c|c|c|c|c|c|c|c|}
\hline & & \multirow{5}{*}{ Carassius auratus } & As(III) & 7-d EC $\mathrm{E}_{50}$ & 490 & & EPA 1985 \\
\hline & & & \multirow{3}{*}{$\mathrm{As}(\mathrm{V})$} & $7-\mathrm{d} \mathrm{LC} 50$ & $24,600-41,600$ & & \multirow{3}{*}{ NRCC 1978} \\
\hline & & & & $24-\mathrm{hr}$ & \multirow{2}{*}{100} & $15 \%$ behavioral impairment & \\
\hline & & & & $48-\mathrm{hr}$ & & $30 \%$ impairment & \\
\hline & & & MSMA & 96-hr LC 50 & 5,000 & & EPA 1985 \\
\hline 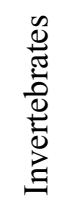 & 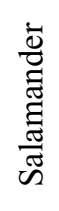 & Ambystoma opacum & As(III) & 8-d EC $\mathrm{E}_{50}$ & 4,500 & $\begin{array}{l}\text { Concentration producing death and } \\
\text { malformations in developing embryos }\end{array}$ & EPA 1985 \\
\hline 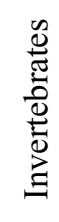 & $\stackrel{\vec{\pi}}{0}$ & Gastrophryne carolinensis & As(III) & $7-d$ & 40 & $\begin{array}{c}50 \% \text { death of malformations noted in } \\
\text { developing embryos }\end{array}$ & EPA 1985 \\
\hline
\end{tabular}




\title{
3. THE IMPACTS OF CENTURY-OLD, ARSENIC-RICH, MINE TAILINGS ON MULTI-TROPHIC LEVEL BIOLOGICAL ASSEMBLAGES IN LAKES FROM THE COBALT, ONTARIO CANADA REGION
}

\author{
Amanda J. Little ${ }^{1}$, Branaavan Sivarajah ${ }^{2}$ Christina Frendo ${ }^{3}$, Dale D. Sprague ${ }^{4}$, John P. Smol ${ }^{2}$, \\ Jesse C. Vermaire ${ }^{1,3}$ \\ ${ }^{1}$ Department of Geography and Environmental Studies, Carleton University, Ottawa, Canada \\ ${ }^{2}$ Department of Biology, Queen's University, Kingston, Canada \\ ${ }^{3}$ Institute for Environmental and Interdisciplinary Sciences, Carleton University, Ottawa, Canada \\ ${ }^{4}$ Department of Earth Sciences, Carleton University, Ottawa, Canada
}

This chapter will be submitted to Science of the Total Environment.

Author Contributions: AJL and JCV developed the study; AJL, BS, CF, \& DDS conducted the fieldwork; AJL, BS, CF, DDS \& JCV analyzed the data; AJL wrote the manuscript with contributions from BS, CF, DDS, JPS \& JCV. 


\section{1: Introduction}

Legacy pollution has been identified as a major threat to the function and health of aquatic ecosystems at various spatial and temporal scales (Thienpont et al. 2016; Luís et al. 2011; Cattaneo et al. 2004; Brännvall et al. 1999). Often, the environmental effects of legacy contamination are difficult to establish because background concentrations for pollutants and long-term monitoring data for many contaminated ecosystems are not available (Leppänen 2018; Sprague \& Vermaire 2018; Thienpont et al. 2016; Meharg et al. 1998). Much of the mining that occurred globally in the late 1800 s to mid-1900s resulted in surface and ground water contamination due to a lack of environmental regulations at the time (Sprague \& Vermaire 2018; Thienpont et al. 2016). As a result, the extent to which historical mining has impacted aquatic ecosystems has not yet been fully quantified, which is particularly troublesome considering that much of the contamination associated with mining activities is highly concentrated with heavy metals and other environmental pollutants (Sprague et al. 2016; Thienpont et al. 2016; Cattaneo et al. 2004).

Arsenic is a potential legacy contaminant of concern due to its widespread distribution in lakes found adjacent to historical mining sites (Sprague et al. 2016; Stewart et al. 2018; Houben et al. 2016; Thienpont et al. 2016). The main source of naturally occurring arsenic is from the weathering and erosion of arsenic-bearing rocks and soil, while anthropogenic sources can include tailings from gold and silver mines, atmospheric deposition from the smelting of arsenicbearing ore, and certain wood preservatives (Thienpont et al. 2016; Wang \& Mulligan 2006). Arsenic in the environment is of particular concern due to its high toxicity and mobility (Sprague et al. 2016; Wang \& Mulligan 2006). Despite the known risks of arsenic in the environment, the majority of data currently available to assess its impacts on freshwater ecosystems are from 
relatively short-term in vitro studies typically lasting 24-96 hours on a single species (He, Megharaj \& Naidu 2009; Jeyashingham \& Ling 2000). As a result, relatively little is known about the long-term (decades or longer) impacts of arsenic in aquatic ecosystems (Nikolaidisa et al. 2004). It is therefore critical that the long-term impacts of arsenic in aquatic environments are better understood in order to implement effective management and mitigation strategies for the protection of aquatic ecosystems.

In order to address this knowledge gap, recent paleolimnological studies have explored the long-term impacts of arsenic on biological assemblages from single lake systems through time (Thienpont et al. 2016; Chen et al. 2015). These paleolimnological investigations have recorded sharp increases in arsenic and other metal contaminant concentrations in lake sediments, which coincide with periods of industrial activity in the catchment (Thienpont et al. 2016; Chen et al. 2015). Concomitantly, decreases in planktonic diatom taxa, the decline and near extirpation of zooplankton assemblages, and shifts in chironomid assemblages were also observed as a potential response to metalloid contamination in these systems (Thienpont et al. 2016; Chen et al. 2015). Furthermore, in a spatial survey of 59 lakes from the Yellowknife area, Nassar et al. (2016) found that the concentration of arsenic in sediment was a major determinant of the assemblage structure of testate amoebae. Despite the fact that mining in the Yellowknife area ceased decades ago, there has been no indication that biological recovery in these systems have occurred (Thienpont et al. 2016).

These studies suggest that arsenic contamination can have long-term impacts on aquatic ecosystems, however, few studies have examined how legacy arsenic contamination may alter important bio-indicator taxa across a spatial gradient of arsenic contamination. The objective of this study is to quantify the impacts, if any, of long-term arsenic exposure on aquatic organisms 
from multiple lakes along a gradient of arsenic contamination $(0.4-1,113 \mu \mathrm{g} / \mathrm{L})$. To meet this objective, water and surface sediment samples were collected from 24 lakes (13 contaminated, 11 uncontaminated) in order to examine if arsenic concentration is a strong explanatory variable of biological community change in aquatic ecosystems.

\section{2: Study Site}

The Town of Cobalt $\left(47^{\circ} 24^{\prime} \mathrm{N}, 79^{\circ} 41^{\prime} \mathrm{W}\right)$ is located in northeastern Ontario, Canada approximately $480 \mathrm{~km}$ north of the City of Toronto (Figure 3-1). Incorporated in 1907, Cobalt is currently home to approximately 1,100 people. It is situated between a clay belt to the north and a region of mixed forest with undergrowth typical of the Boreal Forest to the south. The geology of the area consists of Archean volcanics, which are overlain with Proterozoic sediments from the Cobalt Group (Lorrain and Gowganda formations; Jambor 1971). Silver in the region is found in naturally occurring veins alongside gold, arsenic, and certain sulfides. Cobalt is classified as having a severe humid continental climate resulting in moderately warm summers followed by cold and long winters. This region receives a substantial amount of rainfall, which makes up a large portion of its annual precipitation ( $820 \mathrm{~mm}$; ECCC 2019). Using the standard 30-year historical baseline (1981-2010), the temperature in the region has ranged from a minimum of $-17.8^{\circ} \mathrm{C}$ during the winter months (December, January, February) to $23^{\circ} \mathrm{C}$ during the summer months (June, July, August; ECCC 2019).

Nicknamed the Silver City, Cobalt was once the world's largest producer of silver and was crucial to early economic development in Ontario and Canada. As a result, Cobalt has been named Canada's "Most Historic Town" and is designated a Canadian National Historic Site. From 1904 to the mid-1930s, mining activities continued to spread south of the town into what was known as the Silver Centre in the South Lorrain area $26 \mathrm{~km}$ south of Cobalt (McIlwaine 
1970). The 24 lakes sampled in this study follow a transect of historical mining activity which is $\sim 30 \mathrm{~km}$ in length. The waterbodies in this area flow into the Farr Creek drainage basin, which then flows north of Cobalt and eventually into Lake Temiskaming and the Ottawa River.

During the early $20^{\text {th }}$ century Cobalt underwent a period of intense silver and cobalt mining (Sprague et al. 2016). The region experienced its peak in production in 1911, when over 40 different mining operations were active at the same time, resulting in approximately 29 million ounces of silver being produced during this single year period (Knight 1922). Over 420 million ounces of silver and 380 million ounces of cobalt were extracted from the region by 1962 (Thomson 1964), with the majority of this production having occurred during the first three decades of the twentieth century. Eventually, a decrease in the demand and price for silver led to the gradual decline in mining production in the Cobalt region.

The silver and cobalt in this area are closely associated with naturally occurring arsenic. As a result, much of the waste-rock and tailings from these mining operations have elevated arsenic concentrations. For example, the tailings at Beaver Mine in Cobalt have arsenic concentrations as high as 4,330 mg/kg (Sprague et al. 2016). Due to a lack of environmental management, arsenic-rich mine tailings and waste-rock piles were deposited in nearby water bodies where they have remained for nearly a century (Sprague et al. 2016). Moreover, the movement of arsenic and other heavy metal(loid)s through the migration of mine tailings into previously unexposed water bodies has resulted in further contamination of lakes in the area (Sprague et al. 2016). 


\section{3: Materials \& Methods}

Sediment cores were recovered from 24 lakes spanning an observable arsenic gradient (range of open water arsenic concentrations: $0.4-1,113 \mu \mathrm{g} / \mathrm{L}$ ) in the summer of 2015 . Thirteen of these 24 lakes had clear evidence of mining contamination in their watershed including mine tailings deposited near shore or visible within the lake sediment core and are classified in this study as contaminated lakes. The remaining 11 lakes were not directly impacted by historical mining activity and are classified as non-contaminated sites. Detailed data on the geochemistry of the water and sediment cores from these study sites are reported in Sprague and Vermaire (2018). The diatom assemblages in the surface sediments from these 24 lakes were analyzed to examine diatom community response to mining contamination in the Cobalt region. A subset of ten of these 24 lakes selected over the arsenic gradient ( 6 contaminated, 4 non-contaminated) were resampled in 2017 for analysis of sedimentary Cladocera and chironomid assemblages, open water zooplankton abundance and community composition, and phytoplankton concentration (chlorophyll- $a$ ) in relation to mining contamination at each site.

In each study lake sediment cores were recovered using a Glew gravity corer (Glew 1989) with effort made to collect sediment cores from the deepest portion of the lake, typically the mid-basin. All sediment cores were measured in the field, observed for stratigraphic changes, and subsampled at $1 \mathrm{~cm}$ intervals using a Glew extruder (Glew 1988) for transportation and analysis in the laboratory. Samples were refrigerated in the field and were shipped back to Carleton University where they were stored at $4{ }^{\circ} \mathrm{C}$ until analysis could be completed. Water, zooplankton, and chlorophyll- $a$ samples were collected from approximately $20 \mathrm{~cm}$ below the water surface. Water samples analyzed for metal concentrations were preserved in $0.5 \% \mathrm{HNO}_{3}$ and refrigerated upon initial collection in the field before being shipped to Caduceon 
Environmental Laboratories in Ottawa, Ontario for metal analysis. Triplicate zooplankton samples were obtained using $40 \mathrm{~L}$ of water with a Van Dorn sampler and then filtered through a $250 \mu \mathrm{m}$ Wisconsin zooplankton net before being stored in a $90 \%$ ethanol solution in small plastic vials. All samples were stored in a refrigerator at $4{ }^{\circ} \mathrm{C}$. Triplicate chlorophyll- $a$ samples were obtained from each lake by filtering a known volume of water through Whatman GF/F filters. Once collected, the filters were placed in petri dishes and wrapped in aluminum foil to minimize their exposure to light, and then frozen. Upon returning to Carleton University, these samples were stored in a freezer at $-20^{\circ} \mathrm{C}$ until analyzed.

\subsection{1: Laboratory Analyses}

A suite of trace elements was analyzed from both the water and sediment of the study lakes by Caduceon Environmental Laboratories in Ottawa, Canada, including metals which have been found to be associated with silver mining activities in the Cobalt region (e.g. antimony, arsenic, cobalt, copper, lead, nickel; Sprague \& Vermaire 2018). Geochemical analyses were performed using Induced Coupled Plasma - Mass Spectrometry (ICP-MS) and Induced Coupled Plasma - Atomic Emission Spectrometry (ICP-AES), based on metal concentration (low and high, respectively). Details of these methods and results can be found in Sprague and Vermaire (2018).

Chlorophyll- $a$ samples were obtained by filtering $500 \mathrm{ml}$ of water through Whatman GF/F filters in the field, following the standard procedures outlined by Aminot and Rey (2002). Chlorophyll- $a$ pigments were extracted using $90 \%$ ethanol and vortexed to ensure thorough mixing. The monochromatic method with acidification was used with a spectrophotometer to measure absorbance at $665 \mathrm{~nm}$, and turbidity at $750 \mathrm{~nm}$. The difference in absorbance before and 
after acidification was used to calculate and correct for pheopigment concentration in the sample, as the acidification process degrades all chlorophyll into pheopigments (Aminot \& Rey 2002).

Diatom slides were prepared using the top $0-1 \mathrm{~cm}$ interval slices of the sediment cores, following standard procedures as outlined by Battarbee et al. (2001). Approximately $0.5 \mathrm{~g}$ of wet sediment from each sample was placed in a glass scintillation vial and treated with $10 \%$ hydrochloric acid $(\mathrm{HCl})$ to remove any carbonate material. Each sample was then rinsed with deionized water five times and left to sit for 24 hours between each rinse to allow settling of diatoms. Once this step was complete, each sample was treated with $30 \%$ hydrogen peroxide $\left(\mathrm{H}_{2} \mathrm{O}_{2}\right)$ and then placed in a hot water bath $\left(\sim 70^{\circ} \mathrm{C}\right)$ for 8 hours to digest any organic material in the sample. Once the samples had cooled, they were refilled with deionized water and rinsed seven more times. Once completed, well-mixed aliquots from each vial were deposited onto glass coverslips and were left to dry at room temperature on a covered slide warmer overnight. These cover slips were mounted onto microscope slides using Naphrax ${ }^{\circledR}$. A minimum of 400 diatom valves were identified per sample using a Leica DM 2500 LED microscope under 1000x/1.32 oil immersion lens. Diatom identifications were made to the lowest possible taxonomic level using guides by Krammer and Lange-Bertalot (1986-1991a).

Sediments were processed for Cladocera remains following standard procedures outlined by Korhola and Rautio (2001). Wet sediment samples were deflocculated using a 10\% potassium hydroxide (KOH) solution for 20 minutes on a hotplate, and then rinsed through a $38 \mu \mathrm{m}$ mesh sieve using deionized water. Material retained by the sieve was transferred to a vial and then preserved and stained using ethanol and safranin, respectively. Once thoroughly mixed, aliquots were pipetted onto microscope slides and mounted using glycerin jelly. Cladoceran remains were identified at 200x magnification using a Leica DMR light microscope under bright-field optics. 
A minimum of 100 individuals were identified from each sample (Kurek et al. 2010) and taxonomy followed photomicrographs of Szeroczyńska and Sarmaja-Korjonen (2007), Korosi and Smol (2012 a,b), and Sweetman and Smol (2006). For the purpose of this study, Bosminid headshields were not differentiated at the species level (Bosmina or Eubosmina), as there were challenges associated with locating the required lateral head pores, likely stemming from the high amounts of clastic material found in the samples. Daphniids were classified into either Daphnia longispina complex or Daphnia pulex complex. All Cladoceran remains in each coverslip were examined and all different observable parts were identified where possible. The most abundant remains of a species were then used to calculate the number of individuals and the overall relative abundance of taxa at the study lakes (Kurek et al. 2010).

Chironomids were prepared for analysis using $1 \mathrm{~g}$ of wet sediment from the top $0-1 \mathrm{~cm}$ of each core. Sediment samples were deflocculated in a heated solution containing $10 \% \mathrm{KOH}$ and then sieved through a $100 \mu \mathrm{m}$ mesh and rinsed with deionized water. Chironomid head capsules in the sample were picked from a Bogorov counting chamber and placed onto a cover slip using a Leica S9i dissecting microscope following the standard procedures as outlined by Walker (2001). A minimum of 40 head capsules were collected per sample where possible. Once chironomid head capsules had been collected from each sample, microscope slides were mounted using Entalin. Chironomid head capsules were identified under 200-400x magnification to the lowest possible taxonomic level using the guide by Brooks et al. (2007).

Open-water zooplankton were stored in plastic vials and re-filtered using a $250 \mu \mathrm{m}$ sieve mesh and deionized water (Dhargalkar and Verlecar 2004). Material collected on the mesh was washed into a beaker and poured into a Bogorov counting chamber, where they were examined 
under a Leica S9i dissecting microscope. All individuals were counted and identified down to the lowest taxonomic level possible using the interactive, online guide by Haney (2013).

\subsection{2: Statistical Analyses}

Before any statistical analyses were run, taxa considered to be rare in each bio-indicator community were removed in order to reduce redundancy in the datasets. Diatoms, cladocera, and open-water zooplankton taxa which were observed at $<2 \%$ relative abundance in all lakes were removed from their respective datasets. Chironomids which appeared at $<5 \%$ relative abundance in all lakes were removed due to the large number of individual species identified (63; reduced to 27).

Multivariate statistical techniques were used to explore the relationships between potential environmental drivers and biological responses using the $\mathrm{R}$ statistical programming software (R Core Team 2016). Boxplots and Wilcoxon tests were applied to the datasets to determine whether lake contamination classification (i.e., contaminated versus uncontaminated) had statistically different means for arsenic concentration and chlorophyll- $a$ concentration. Stratigraphic plots were created for all of the bio-indicators using the "rioja" package (Juggins 2015).

All environmental data were tested for normal distribution using the Shapiro-Wilk test, and transformed as needed. Biological proxy relative abundance values were square roottransformed to reduce the influence of dominant taxa. A correlation matrix of the environmental variables was plotted using the "corrplot" R package (Wei \& Simko 2016) to determine the degree of correlation between the water chemistry parameters. When variables were found to be strongly correlated $(\mathrm{R} \geq 0.7)$, one of the environmental variables was removed in order to elimate highly correlated environmental variables from further analyses. 
A de-trended correspondence analysis was then used to determine if linear or unimodal ordination techniques were more appropriate for the datasets (Birks 2010). Since the gradient lengths were $<3$, linear ordination techniques such as principal components analyses (PCA) and redundancy analyses (RDA) were selected (ter Braak \& Prentice 1988). The “vegan” package (Oksanen et al. 2015) was used to conduct the PCAs and RDAs to summarize the differences in the biological assemblages and their relationships to environmental variables, respectively. A forward selection process was used to cross-verify whether arsenic, or any other potential explanatory variables, were significant drivers of biological assemblages in the studied lakes. Arsenic was also added alone as an environmental variable in an RDA for each bio-indicator to quantify the percent variability in the species assemblages explained by arsenic concentration alone. Finally, linear regression modelling was used to compare the first PCA axis to arsenic concentration in the study lakes, as well as for each bio-indicator in order to determine the relationships between different biological taxa and their response to arsenic input in lakes from the Cobalt region.

\section{4: Results}

\subsection{1: Water Chemistry}

Water chemistry data showed highly alkaline $\mathrm{pH}$ and elevated metal concentrations in the contaminated lakes in both 2015 (Table 3-1) and 2017 (Table 3-2). Arsenic, pH, lead, zinc, and copper were all found to be outside of the CCME surface water guidelines for the protection of aquatic life in at least one of the 24 lakes. Arsenic ranged from $0.4-1,113 \mu \mathrm{g} / \mathrm{L}, \mathrm{pH}$ from $6.9-$ 9.17, lead from $0.02-1.21 \mu \mathrm{g} / \mathrm{L}$, zinc from $5-53 \mu \mathrm{g} / \mathrm{L}$, and copper from $0.1-2.3 \mu \mathrm{g} / \mathrm{L}$. Fifteen of the 24 lakes had arsenic concentrations greater than the CCME freshwater guideline for the protection of aquatic life $(5 \mu \mathrm{g} / \mathrm{L})$, including two uncontaminated lakes (North Pickerel $=5 \mu \mathrm{g} / \mathrm{L}$, 
Silver $=7.3 \mu \mathrm{g} / \mathrm{L})(\mathrm{CCME} 2001)$. Although currently uncontaminated, Nicol Lake was found to be outside the recommended CCME (2003) guidelines for a variety of different environmental variables including $\mathrm{pH}(9.17)$, lead $(1.21 \mu \mathrm{g} / \mathrm{L})$, zinc $(9 \mu \mathrm{g} / \mathrm{L})$, and cadmium $(0.12 \mu \mathrm{g} / \mathrm{L})$.

Regardless of contamination status, many of the lakes in this dataset were found to be over the CCME guideline of $7 \mu \mathrm{g} / \mathrm{L}$ for zinc, with the highest concentration $(53 \mu \mathrm{g} / \mathrm{L})$ found in Pine Lake, which was also the lake with the lowest arsenic concentration $(0.4 \mu \mathrm{g} / \mathrm{L})$. While copper was found to follow a similar increasing gradient to arsenic, only North Peterson and Cobalt Lake were found to have copper concentrations above the CCME guideline $(2 \mu \mathrm{g} / \mathrm{L})(\mathrm{CCME}$ 2003). The concentration of arsenic was significantly greater in contaminated than uncontaminated lakes $(\mathrm{p}<0.01$; Supplementary Figure 3-1). Despite the differences in metal concentrations between contaminated and uncontaminated lakes, there was no significant difference in open water chlorophyll- $a$ concentration between these categories, suggesting that metal concentration did not influenced phytoplankton biomass in these lakes (Supplementary Figure 3-2).

\subsection{2: Diatoms}

A total of 215 diatom taxa were identified in the 24 lakes of which of 32 taxa were considered common ( $\geq 2 \%$ relative abundance in at least one lake) and included in statistical analysis (Figure 3-2). Achnanthidium minutissimum and Staurosirella pinnata were present in all study lakes, and occurred in notable abundances. However, Staurosira construens was observed to reach the highest relative abundance at greater than $50 \%$ of the assemblage in Ibsen Pond, a contaminated lake with a surface water arsenic concentration of $142 \mu \mathrm{g} / \mathrm{L} . A$. minutissimum and S. pinnata, both reached a relative abundance of $40 \%$ in contaminated lakes 
North Peterson and Kerr, respectively, while Psammothidium marginulatum reached $40 \%$ relative abundance in the uncontaminated North Pickerel Lake.

Certain diatom species such as Caloneis silicula, Tabellaria flocculosa and Fragilaria capucina were observed to be relatively sensitive to high arsenic concentrations and were found to be correlated with arsenic concentrations ( $\mathrm{p}=0.01,0.03$ and 0.03 , respectively). Other species, such as Staurosira construens, Encyonopsis microcephala, Psammothidium ventrale, and Diploneis modica, appeared in greater abundance in lakes with higher arsenic concentrations, however, these trends were not statistically significant $(\mathrm{p}=0.4,0.1,0.4$, and 0.3 , respectively). Species which appeared to be relatively unaffected by changes in arsenic concentration included Achnanthidium minutissimum, Staurosirella pinnata, Lindavia bodanica, and Lindavia michiganiana, all of which did not have a statistically significant relationship with arsenic $(\mathrm{p}=0.9$ for all taxa).

The PCA and RDA ordinations highlighted that there was no strong relationship between surface water arsenic and sedimentary diatom assemblages (Figure 3-3). In the PCA, 21\% of the total variance in the dataset was explained along axis 1 , while an additional $13 \%$ was explained by axis 2 . Arsenic did not have a strong influence on the diatom assemblages as Pine and Cart lake were located close to one another within the same quadrant despite representing the two ends of the arsenic gradient spectrum ( 0.4 and $1,113 \mu \mathrm{g} / \mathrm{L}$, respectively). The RDA ordination highlighted that water depth, lead, and $\mathrm{pH}$ were the three variables which loaded the highest along the RDA1 axis, corresponding to approximately $18 \%$ of the data variance.

An RDA was run using arsenic as a single explanatory variable, and it was determined that arsenic explained $\sim 4 \%$ of the total variance in the diatom assemblage and was not 
statistically significant $(\mathrm{p}=0.7)$. Furthermore, PCA axis 1 site scores for the diatom species were not correlated with arsenic concentration in the study lakes, indicating that arsenic was not a major driver of diatom assemblages in our 24 lake dataset (Figure 3-4).

While the RDA forward selection process did not identify arsenic as a significant driver of diatom community assemblage in sampled lakes from the Cobalt region, it did highlight water depth $(\mathrm{p}=0.005)$, lead $(\mathrm{p}=0.03)$, and $\mathrm{pH}(\mathrm{p}=0.045)$ as having potential significance in the system. When plotted against the PC1 axis site scores for the diatom community, all three of these variables were found to be significant (Supplementary Figure 3-3, 3-4, 3-5). Water depth was identified as the most important variable, and both the PCA and RDA ordination plots showcase its influence on diatom community structure as many planktonic diatom species, such as Aulocoseira distans, Discotella stelligera, and Pantocsekiella ocellata, can all be observed to load higher along this gradient.

\subsection{3: Cladocera}

Twenty-nine Cladoceran taxa were identified in 9 of the 10 lakes used in the subset, but only 21 were found to be common ( $\geq 2 \%$ relative abundance in at least one lake) and therefore used in statistical analysis. Bosmina species dominated the assemblages across most lakes and were found to make up over $90 \%$ of the sedimentary population in both Clear and Crosswise lakes (Figure 3-5). While Bosmina species appeared to be relatively unaffected by high arsenic concentrations, the abundance of Bosmina was less than $10 \%$ in Cart Lake, the most

contaminated lake included in the study $(1,113 \mu \mathrm{g} / \mathrm{L})$, and was essentially replaced by Chydorus brevilabris which appeared in Cart Lake at an abundance of almost 60\%. Incidentally, Chydorus brevilabris also appeared to be more abundant in lakes with higher levels of arsenic. Daphnia pulex complex was observed only in contaminated lakes and reached its highest abundance in the 
second most contaminated lake (Cobalt Lake $=505 \mu \mathrm{g} / \mathrm{L}$ ). However, both of these taxa were found to not have a statistically significant relationship with arsenic $(p=0.14$ and 0.22 , respectively). Alonella nana appeared to be the most sensitive to high arsenic concentrations and was found to be more abundant in uncontaminated lakes. The negative relationship between Alonella nana and arsenic was statistically significant $(\mathrm{p}=0.04)$. Camptocercus species was also found to have statistically significant $(p=0.05)$ trend with arsenic concentration, but in relative abundances much lower than Alonella nana.

The PCA axes 1 and 2 were found to explain $31 \%$ and $25 \%$ of the variance within the dataset, respectively, while RDA axes 1 and 2 explained 29\% and 21\% (Figure 3-6). The RDA highlighted arsenic, lead, calcium, and iron as loading the highest along the RDA1 axis, although the values obtained were still relatively low. The RDA analysis using arsenic as a single explanatory variable, found that the metalloid explained up to $15 \%$ of the variance in the Cladoceran dataset. The forward selection process identified iron, arsenic, and water depth as the three most important variables in the dataset, but none of these were found to be statistically significant, possibly due to the smaller sample size of 9 lakes $(p=0.13,0.16,0.29$, respectively). results of the ordination techniques therefore showed no statistically significant relationship between surface water arsenic $(\mu \mathrm{g} / \mathrm{L})$ and the observed Cladoceran taxa as a whole. When the Cladoceran species scores obtained from the PCA ordination were plotted against the gradient of arsenic, the overall relationship was found to be non-significant $(\mathrm{p}=0.22)$ (Figure 3-4).

\subsection{4: Chironomids}

Sixty-three chironomid taxa were identified in the 10-lake subset, of which 27 were found to be common and included in statistical analysis. In this case, a threshold of $\geq 5 \%$ relative abundance in at least one lake was used. The most common species were Tanypodinae, Einfelda 
pagana-type, Tanytarsus lugens-type, and Chironomus anthracinus-type (Figure 3-5). The chironomid assemblages were very diverse across the 10 lakes, and as a result, many species were typically present in only one or two of the lakes. The highest relative abundance was $20 \%$ for Endochironomus albipennis type and Einfeldia pagana type, and $40 \%$ for Tanypodinae. All three of these taxa appeared to be relatively tolerant of changes in arsenic concentrations as they occurred in notable abundances in almost all of the lakes. Chironomus anthracinus type and Cricotopus othrocaldius occurred in lakes with relatively high arsenic concentration but the relationships between their relative abundance and arsenic concentrations were not significant $(\mathrm{p}$ $=0.63,0.27)$. Of the 27 common chironomid species identified, only Microtendipes pedullus type was found to have a statistically significant relationship $(\mathrm{p}=0.03)$ with arsenic, and underwent its highest abundance in the lowest contaminated lake (6\% in Oxbow Lake; $0.9 \mu \mathrm{g} / \mathrm{L})$, and disappeared from the record altogether after Crosswise Lake.

PCA axis 1 and 2 explained $20 \%$ and $18 \%$ of the total variance within the dataset respectively (Figure 3-6), while RDA axis 1 and 2 were observed to explain $17 \%$ and $16 \%$. Arsenic was found to explain up to $8 \%$ of the variance within the chironomid dataset when included in an RDA as the single explanatory variable, but was not statistically significant. The forward selection process identified $\mathrm{pH}$ and water depth as the most important variables in the system, although these relationships were not significant $(p=0.18, p=0.21)$. Chironomid PC1 species scores were plotted against the gradient of arsenic and found to be not significant $(\mathrm{p}=$ 0.96) (Figure 3-4).

\subsection{5: Zooplankton}

Of the 19 identified open-water zooplankton taxa, only nine were considered to be common ( $>2 \%$ relative abundance in at least one lake) and used in further statistical analysis. 
The most common zooplankton species were Hydracarina, Rotifera brachionidae, and Copepoda calanoida (Figure 3-5). Of all the identified zooplankton types, Rotifera bracionidae was found to be the most abundant, reaching the highest recorded relative abundance of $80 \%$ in both North Pickerel and Brady Lakes. While present in almost all of the 10 sampled lakes, Rotifera brachionidae appeared to be relatively insensitive to changes in arsenic concentration. Cladocera bosminidae and Copepoda ergasilidae were both observed to appear in higher abundances in lakes with high arsenic concentrations, but were found to have statistically nonsignificant relationships with arsenic (p-values of 0.6 and 0.06 , respectively).

The first two PCA ordination axes were found to explain 35\% and $20 \%$ of the variance within the dataset (Figure 3-6). RDA axis 1 and 2 explained 32\% and 18\%. Arsenic was once again identified as having a low loading score along RDA axis 1 , was found to explain only $13 \%$ of the total variance within the zooplankton dataset, and was not statistically significant. However, while arsenic was not found to be statistically significant, calcium was $(p=0.045)$. Cobalt and lead were also identified as being potentially important drivers of zooplankton community composition, although these relationships were not statistically significant $(\mathrm{p}=$ $0.055,0.115$, respectively). When plotted against the PC1 site scores for the cladoceran community, calcium was not found to have a significant influence $(p=0.2015)$. There was no significant correlation between $\mathrm{PC} 1$ axis from the zooplankton data and arsenic concentration (p $=0.7)$ (Figure 3-4).

\section{5: Discussion}

Historical mining activity has altered the geochemistry of many lakes in the Cobalt region, including increasing arsenic concentrations in water and sediments orders of magnitude beyond natural conditions. Despite these impacts, arsenic concentration of surface water had 
little influence over changes in species assemblages of important bio-indicators across our study lakes. Although some individual taxa did show a relationship with arsenic concentration, the overall effect of arsenic contamination on community structure in our study area was surprisingly modest. While previous research has shown large impacts of arsenic contamination on species assemblages both temporally (Thienpont et al. 2016; Chen et al. 2015) and spatially (Nasser et al. 2016), arsenic appears to have had little influence in structuring bio-indicator communities across a landscape of lakes. These results suggest that other environmental factors may be more important than arsenic at influencing community composition. For example, lake depth, $\mathrm{pH}$, and lead were all found to be statistically significant in driving diatom community assemblage in the Cobalt region. It is therefore possible that other environmental controls which were not included in this study may be having an influence. As a result, it should not be ruled out that arsenic may ultimately have an impact at the ecosystem scale when compounding controls are accounted for in study design. In addition, this study measured total arsenic in the lakes, and it is possible that additional information on arsenic speciation may increase our understanding of how arsenic contamination has impacted aquatic ecosystems in the Cobalt region.

\subsection{1: Impact(s) of surface water arsenic on bio-indicators in the Cobalt region}

Despite having statistically significant relationships with a few individual species, total arsenic did not appear to be a strong driver of biological community structure as a whole in the Cobalt region. Of the four main bio-indicators observed in this study, arsenic had the most influence in the Cladocera community, where it was found to explain upwards of $15 \%$ of the total variance in the data. However, the relationship between arsenic and Cladocera taxa, as well as the rest of the bio-indicators, was not found to be statistically significant. The diatom 
community, in particular, was found to have the lowest amount of its variance explained by $\operatorname{arsenic}(4 \%)$.

Of the diatom species analyzed in this study, Caloneis silicula, Tabellaria flocculosa, and Fragilaria capucina were all found to have statistically significant negative relationships with arsenic at a spatial-scale in the Cobalt region, while Staurosirella pinnata and Achnanthidium minutissimum were both relatively tolerant of arsenic contamination. A. minutissimum in particular has been documented as being tolerant of arsenic (Barral-Fraga et al. 2016; Thienpont et al. 2016). Similar trends were also observed in Lac Dufault, a lake impacted by historical mining activities in the Abitibi region of Québec, Canada, located approximately $100 \mathrm{~km}$ away from the Cobalt region study site (Catteneo et al. 2004). In Lac Dufault, T. flocculosa was abundant prior to the onset of mining activities with $A$. minutissimum becoming the more dominant taxa with the onset of metal contamination in the system (Catteneo et al. 2004). With the cessation of mining in the region, a subtle increase in certain Fragilaria species was observed, coinciding with the decline of mining pollutant levels in the lake back towards preindustrial levels (Cattaneo et al. 2004). This current study, as well as both Barral-Fraga et al. (2016) and Cattaneo et al. (2004), therefore suggest that $T$. flocculosa is sensitive to increases in arsenic contamination, specifically.

Zinc, cadmium, and iron have also been identified as important mining-related metals in both the Cobalt and Lac Dufault regions (Catteneo et al. 2004). As with arsenic, T. flocculosa has been observed to be sensitive to metal inputs, particularly zinc and copper (Gonçalves et al. 2018; Cattaneo et al. 2004; Austin \& Munteanu, 1984). A. minutissimum has been observed as being tolerant to mining pollution in general under a variety of different contamination conditions (Luís et al. 2011; Cattaneo et al. 2004; Verb \& Vis, 2000; Dixit et al. 1991). An 
increase in dominance by $A$. minutissimum coinciding with the onset of mining contamination was reported by Thienpont et al. (2016) in a severely arsenic contaminated lake in Yellowknife, further highlighting this species' wide geographic distribution and metal tolerance.

While F. capucina was observed to increase in abundance with elevated arsenic in the Cobalt region, it was observed to increase with high copper concentrations in Lac Dufault (Cattaneo et al. 2004). Although copper in the Cobalt region also generally increased in lakes with high arsenic concentrations, the observed increase in F. capucina abundance in Lac Dufault was short lived as metal concentrations continued to increase and the community assemblage shifted dominance towards the more tolerant A. minutissimum (Cattaneo et al. 2004). It is therefore likely that the observed shifts in spatial diatom community assemblages in the Cobalt region were the result of metal pollution in general, as opposed to just a single contaminant such as arsenic.

The Cladocera Daphnia cf. pulex, and Chydorus brevilabris appeared to increase in abundance with elevated arsenic concentrations in the Cobalt area. These species were also observed to increase in a mining-related metal contaminated lake in Yellowknife, however, they were ultimately functionally lost from the sediment record once a certain pollution threshold was reached (Thienpont et al. 2016). Similarly, Tenkouano et al. (2019) also observed an increase in the abundance of these two species in Moira Lake, a lake in Ontario host to extensive goldmining contamination ( $200 \mathrm{~km}$ from Cobalt). In Moira Lake, both Daphnia $c f$. pulex, and Chydorus brevilabris did not begin to decrease in abundance until decades after the closure of the mine (Tenkouano et al. 2019). Daphnia cf. pulex, and Chydorus brevilabris are still present in high relative abundances in contaminated lakes from the Cobalt region. In a study on the impacts of mining in Wawa, Ontario ( 400 km from Cobalt), Jeziorski et al. (2013) observed the 
dominance of Bosmina species with Alonella nana present during the pre-mining period, followed by an increase in Chydorus brevilabris during peak metal contamination.

The weak influence of arsenic contamination on the observed bio-indicators from Cobalt, Ontario, may be the result of the chemical speciation of arsenic in the lakes included in this study. He et al. (2009) investigated the toxicities of three different arsenic species (As(III), As(V), and a combination of the two) on the Cladoceran Daphnia carinata. As(III) was determined to be the most toxic form of arsenic to the species, with an $\mathrm{LC}_{50}$ of $554 \mu \mathrm{g} / \mathrm{L}$, while $\mathrm{As}(\mathrm{V})$ and the combination of the two arsenic species were found to be 1,499 and $692 \mu \mathrm{g} / \mathrm{L}$, respectively (He et al. 2009). In our study only Cart Lake, the most contaminated lake in the study with a surface water arsenic concentration of $1,113 \mu \mathrm{g} / \mathrm{L}$, was found to be above the $\mathrm{As}(\mathrm{V})$ $\mathrm{LC}_{50}$ value of $692 \mu \mathrm{g} / \mathrm{L}$. Although the He et al. 2009 study took place in lab and over a short period of time (48 hours), its results suggest that much higher concentrations of arsenic than the CCME guideline $(5 \mu \mathrm{g} / \mathrm{L})$ are likely required before long-term exposure to arsenic can significantly impact Cladocera taxa, particularly for systems with more than one species of arsenic present, and which are mediated by microbial activity. While As(III) is the more toxic form of arsenic, a wetland survey conducted in Cobalt revealed that only 13\% of the total arsenic present in the region was made up of As(III) (Percival et al. 2004). Furthermore, He et al. (2009) observed that even when water samples were spiked with As(III), approximately $25 \%$ of it was converted to $\mathrm{As}(\mathrm{V})$ within a 48-hour period. It is therefore likely that the $\mathrm{LC}_{50}$ of total arsenic for Cladoceran taxa in the Cobalt region lakes would be much higher than the $692 \mu \mathrm{g} / \mathrm{L}$ threshold observed by He et al (2009).

When compared to the results of previous studies of arsenic contaminated lakes from Yellowknife (Stewart et al. 2018; Thienpont et al. 2016), chironomids in the Cobalt region 
remained relatively un-impacted by elevated arsenic concentrations. When changes in relative abundance were observed, they did not closely resemble what was observed in Pocket Lake (Thienpont et al. 2016), but they did appear to resemble some of the results observed in Niven Lake - a lake impacted by both mining and other environmental stressors, such as land-use changes (Stewart et al. 2018). While Tanytarsus-type taxa were present in all three systems (Niven Lake, Pocket Lake, and Cobalt), they appeared to dramatically increase in abundance with the input of mining-related contaminants in Pocket Lake (Thienpont et al. 2016), while increasing only slightly along the gradient of arsenic in the Cobalt region before dropping off. The Tanytarsus-type taxa recorded in the Stewart et al. (2018) study indicated relatively little change during gold mining operations, but were observed to spike in overall abundance with the onset of sewage inputs into the lake. Polypedium nubeculosum-type were observed in all three studies as increasing in abundance with the early onset of mining, but then decreasing as pollution thresholds were presumably reached (Stewart et al. 2018; Thienpont et al. 2016).

Previous research on chironomids has provided evidence that speciation of arsenic and the age of chironomids are key determinants of toxicity to non-biting midges (Jeyasingham \& Ling 2000). Specifically, laboratory-based experiments have shown that tolerance to elevated metal concentrations increase with age in chironomid taxa (Jeyasingham \& Ling 2000; Williams et al. 1986). Some studies have noted a trend of fewer chironomid specimens being observed at more contaminated sites (Swansburg et al. 2009; Mousavi, Primicerio \& Amundsen, 2003), however this was not observed in this study (Supplementary Figure 3-6).

Of the zooplankton analyzed in this study, Rotifera brachionidae appeared to be moderately tolerant of arsenic and other mining-related contamination. In other studies, Brachionus havaensis have been found to have an $\mathrm{LC}_{50}$ of $419 \pm 8.1 \mu \mathrm{g} / \mathrm{L}$ for cadmium and 
$2271.0 \pm 404.4 \mu \mathrm{g} / \mathrm{L}$ for zinc (Juárez-Franco et al. 2007). Salinity and temperature are also known controls on the potential toxicity of heavy metals such as copper on Brachionids (GamaFlores et al. 2005). A variety of different variables, including both environmental and chemical inputs, have different influences on the effects and toxicity of heavy metals and other contaminants on zooplankton like Rotifera brachionidae, allowing the taxa to be fairly tolerant to changing inputs of anthropogenic pollution, such as mining-related contaminants. Detecting the influence of arsenic contamination on biological assemblages may, therefore, be complex as many limnological variables could influence the community structure of aquatic bio-indicators in the Cobalt region. It is probable that other chemical, environmental, and geographical factors, possibly in combination with one another, could therefore be more important in influencing community structure in the area.

\subsection{2: Influence of environmental variables on bio-indicators in lakes from the Cobalt region}

While arsenic does not appear to be a driver of bio-indicator community composition at a spatial scale in the Cobalt region, other environmental variables, such as water depth, $\mathrm{pH}$, and lead, have been observed as having significant influence on the sampled ecosystems. Water depth and $\mathrm{pH}$ appear to be of particular importance and have been the focus of many paleolimnological studies for decades (Moos et al. 2005; Brugam et al. 1998; Weckström et al. 1997). The highlighted significance of environmental variables such as water depth and $\mathrm{pH}$ for diatoms, as well as calcium for zooplankton, indicate the important role that lake morphometry and landscape setting have in the organization of aquatic ecosystems.

It should also be noted, that other important environmental variables, such as temperature, the presence and concentrations of dissolved organic carbon (DOC) and organic matter (OM), littoral zone structure, seasonality, and stratification were not included for analysis 
in this study. These variables are critical in lake ecosystem structure, as they influence where certain organisms can live. DOC and OM are of particular importance when considering the bioavailability and toxicity of certain environmental contaminants like heavy metal(loid)s such as copper and arsenic. For example, a 2010 study by Gillis et al. found that the addition of DOC in acute copper toxicity tests of larval freshwater mussels (Glochida) increased the EC50 of copper under a variety of different conditions (i.e., concentration, length of time, species of mussels exposed, etc.). Labile OM (S1) has been identified as an important control of arsenic precipitation in subarctic lakes (Galloway et al. 2018), and better understanding of how DOC and OM behave in the Cobalt region may have allowed for fuller interpretations of the results of this study.

It is therefore possible that arsenic and other mining-related contaminants are playing a role in the overall structuring of ecosystem communities, but that these effects were not picked up on in the analysis used in this study due to the large amount of variability between the studied lakes. The intention of this research was to determine whether long-term exposure to arsenic had significantly impacted lakes in the Cobalt region, and under the conditions set in this study, it was not found to play an important role. Therefore, future studies interested in the impacts of arsenic in the environment should attempt to reduce the overall variability between study sites in order to have a better understanding of the metalloid's role on impacted ecosystem structure, with specific focus on lake morphometry.

\section{6: Conclusions}

Mining-related arsenic contamination of Canadian lakes has been identified as a potential environmental concern due to its widespread distribution and high concentrations. Although many of the lakes in the Cobalt region have arsenic concentrations, which are substantially 
greater than the CCME freshwater guideline for the protection of aquatic life $(5.0 \mu \mathrm{g} / \mathrm{L})$, the overall effect of arsenic contamination on biological assemblage change among our study lakes was relatively modest. While some relationships were detected at the species-specific level with arsenic concentration, overall it appears that other factors such as lake morphometry and $\mathrm{pH}$ for example are more important in driving community assemblage change among these lakes. These results highlight the need for more spatial studies over gradients of metal contamination in order to increase our understanding of how mining related pollution may be impacting aquatic ecosystems in Canada and to develop restoration targets for mining impacted lakes. 


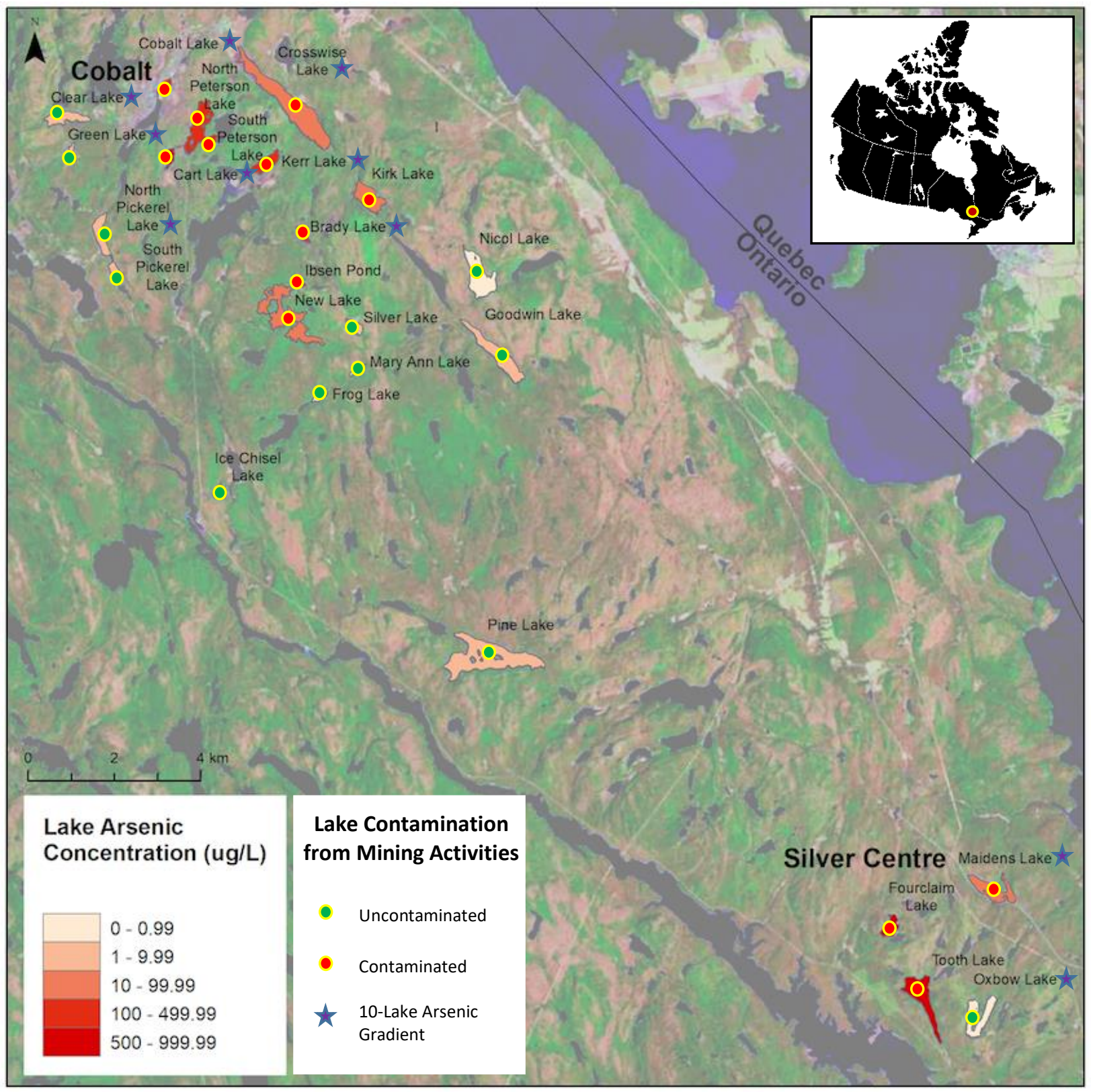

Figure 3-1: Map of Cobalt, Ontario, Canada with study lakes highlighted and the Silver Centre region indicated to the south. Lakes marked with green circles are currently uncontaminated, lakes marked with red circles are contaminated with mining-related arsenic. Lakes indicated with a star are included in the 10-lake gradient subsample study. Lakes are shaded by the amount of arsenic present with lighter reds indicating lower levels of arsenic and darker reds indicating higher levels. Only water bodies indicated as used in this study are shaded with their arsenic concentration. 


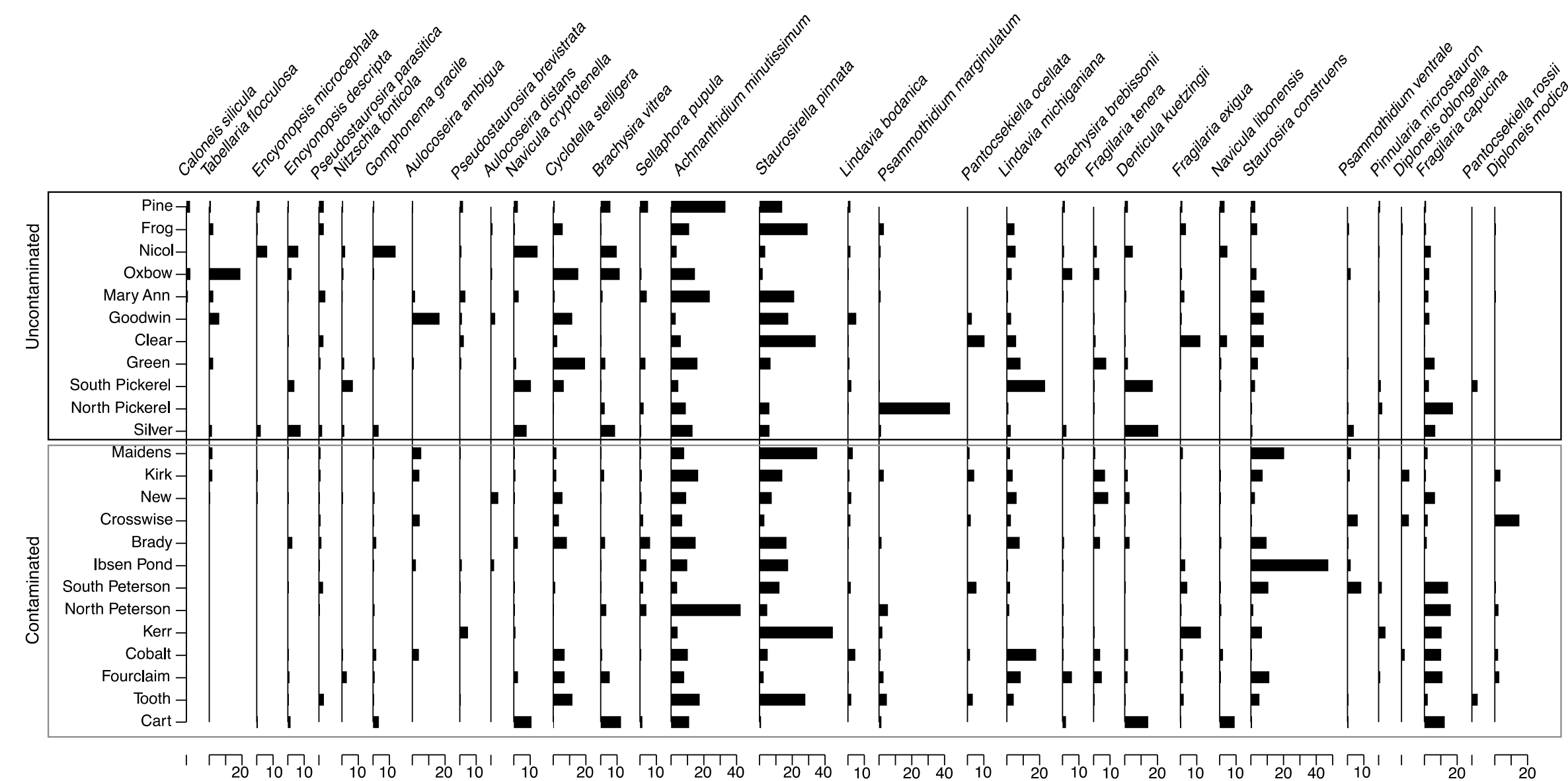

Figure 3-2: Plot of diatom indicator taxa found at $2 \%$ or higher in at least one of the 24 lakes within the Cobalt, Ontario region. Lakes and diatom taxa have both been sorted from lowest to highest arsenic levels in order to show a potential relationship between arsenic and diatoms. Lakes located in the black box are currently uncontaminated while lakes located in the grey box are contaminated. 

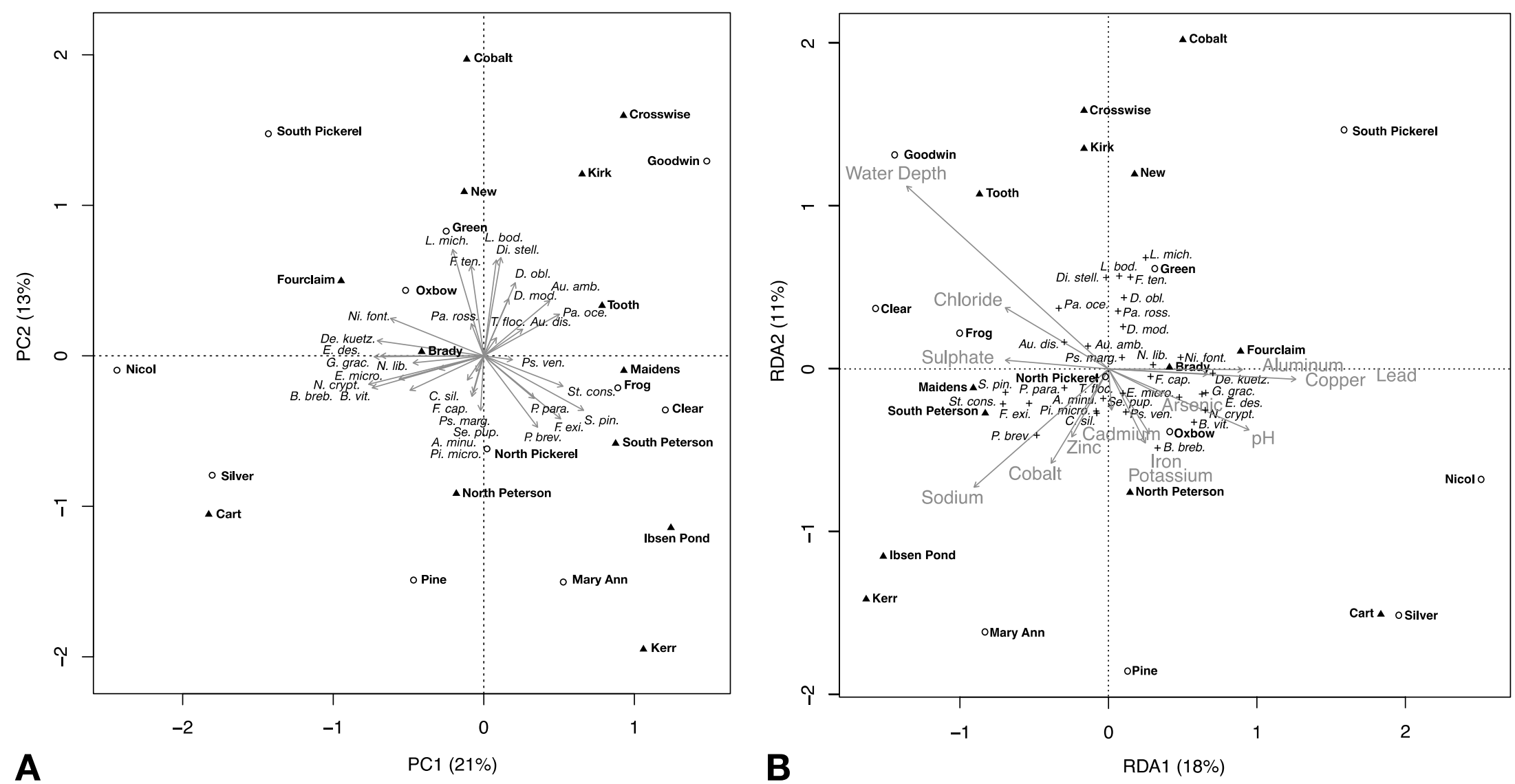

Figure 3-3: A) Principal component analysis (PCA) of the most common diatom taxa found in the 24 lakes in the Cobalt, Ontario region along the PC1 and PC2 axes. PC1 was found to explain $21 \%$ of the variance within the dataset while PC2 explains 13\%. All contaminated lakes are indicated with a black triangle, while currently uncontaminated lakes are marked by black circles. Full taxa names and corresponding abbreviations can be found in Supplementary Table 1. B)

Redundancy analysis (RDA) of the most common diatom taxa and selected chemical variables within the 24 lakes along RDA axes 1 and 2. Grey lines indicate the direction and strength of the explanatory chemical variables while lakes are indicated by black circles and diatoms by abbreviated names. RD1 was found to explain $18 \%$ of the variance within the dataset while RD2 explains $11 \%$. 

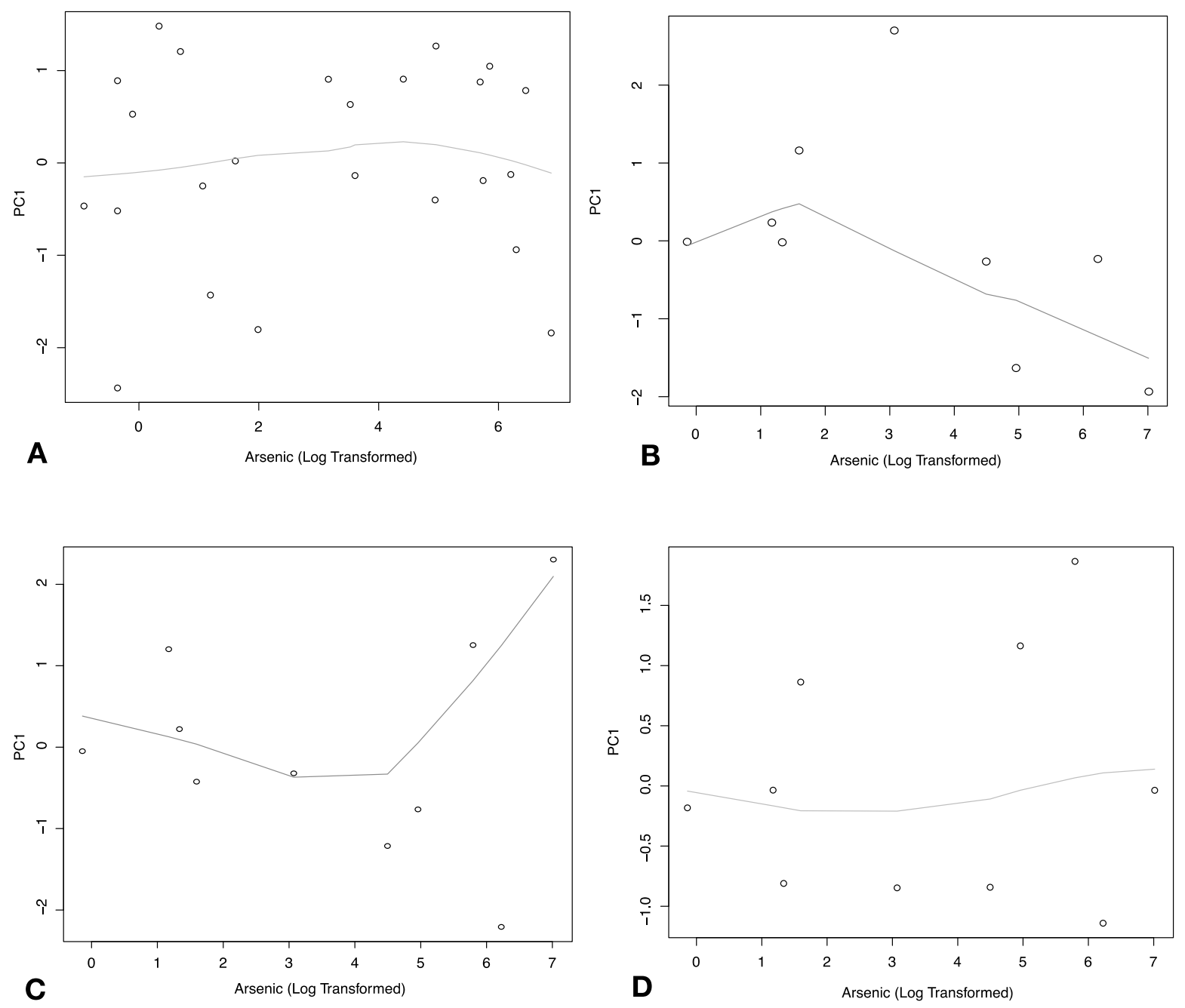

Figure 3-4: Plots of PC1 axes of the bio-indicator site scores versus surface water arsenic concentration - A) diatoms, B) Cladocera, C) chironomids, D) zooplankton. None of these relationships were statistically significant. 


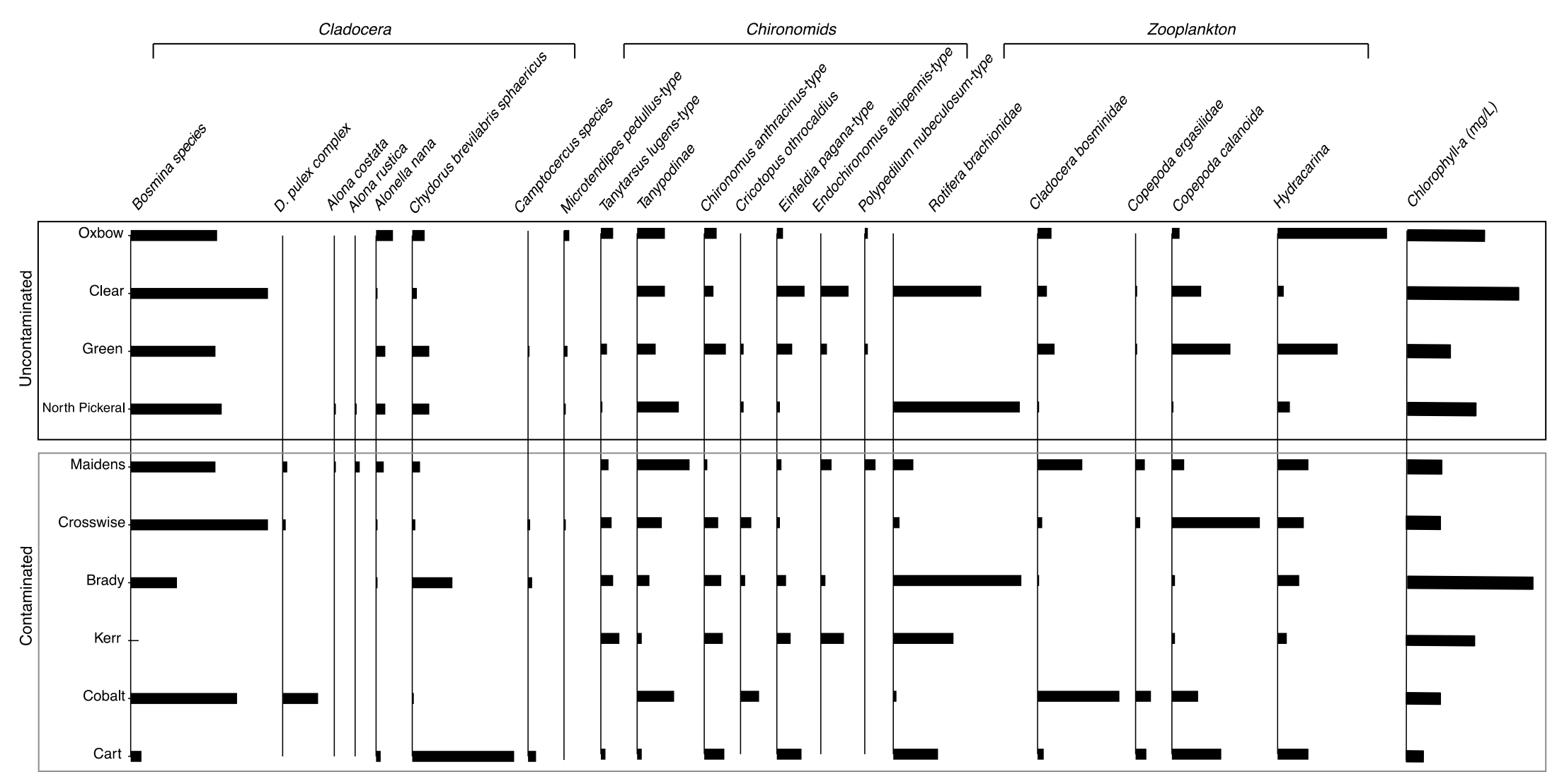

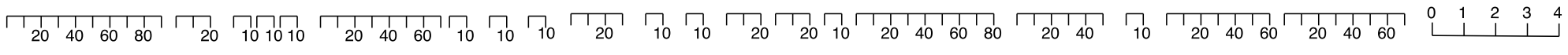

Figure 3-5: Plot of some of the most common Cladocera, chironomid, and open water zooplankton indicator taxa along the 10 lake gradient from the Cobalt, Ontario region. Chlorophyll-a concentrations included on the right. Lakes which are currently uncontaminated are highlighted with black boxes, while lakes contaminated with mining-related arsenic are highlighted in grey boxes. 

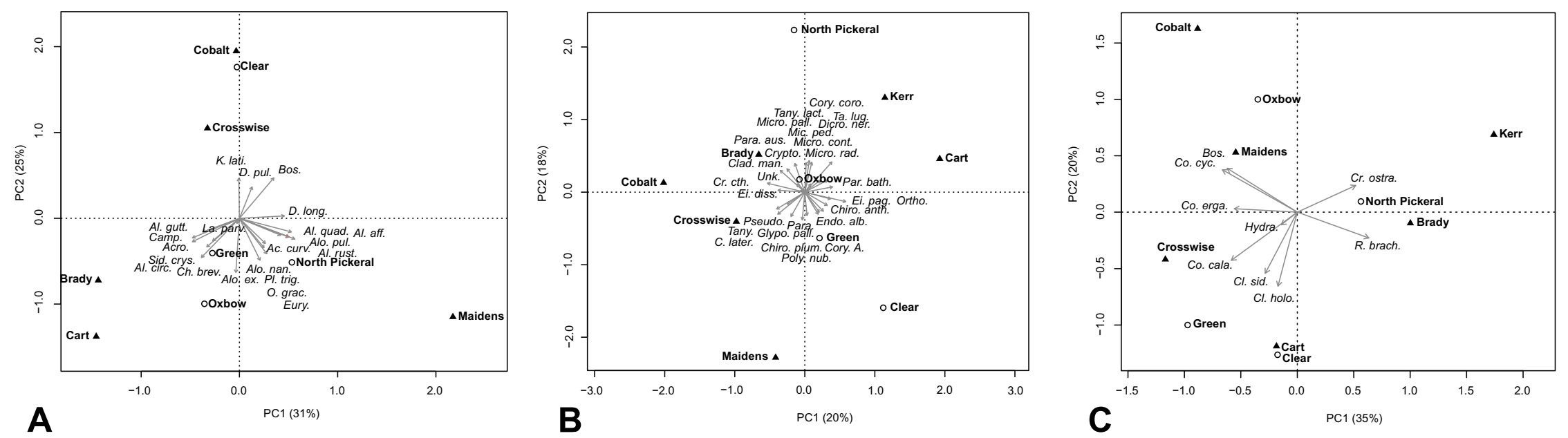

Figure 3-6: Principal component analysis (PCA) ordination plots for Cladocera (A), chironomid (B), and zooplankton (C) indicator taxa. Lakes indicated with black triangles are contaminated, while lakes marked with a black circle are currently uncontaminated. Full taxa names and corresponding abbreviations can be found in Supplementary Table 3-1: Bio-indicator taxa short forms used in ordination plots.. A) Cladocera along the 10-lake gradient. PC1 explains $31 \%$ of the variance within the dataset while PC2 explains $25 \%$. B) Chironomids along the 10 -lake gradient. PC1 explains $20 \%$ of the variance within the dataset while PC2 explains $18 \%$. C) Zooplankton along the 10-lake gradient. PC1 explains 35\% of the variance within the dataset while PC2 explains $20 \%$. 


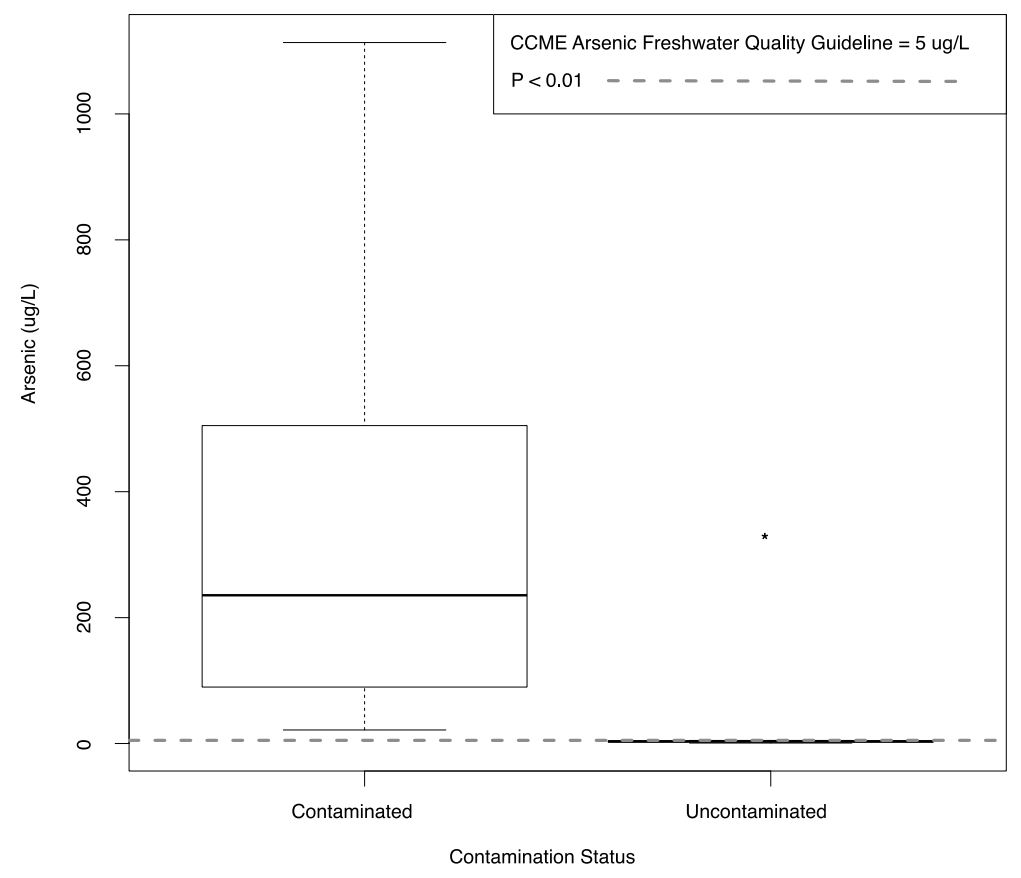

Supplementary Figure 3-1: Box and whisker plot showing the difference in means between surface water arsenic concentration $(\mu \mathrm{g} / \mathrm{L})$ in lakes classified as contaminated (13) and uncontaminated (11). Relationship determined to be statistically significant $(\mathrm{p}<0.01)$.

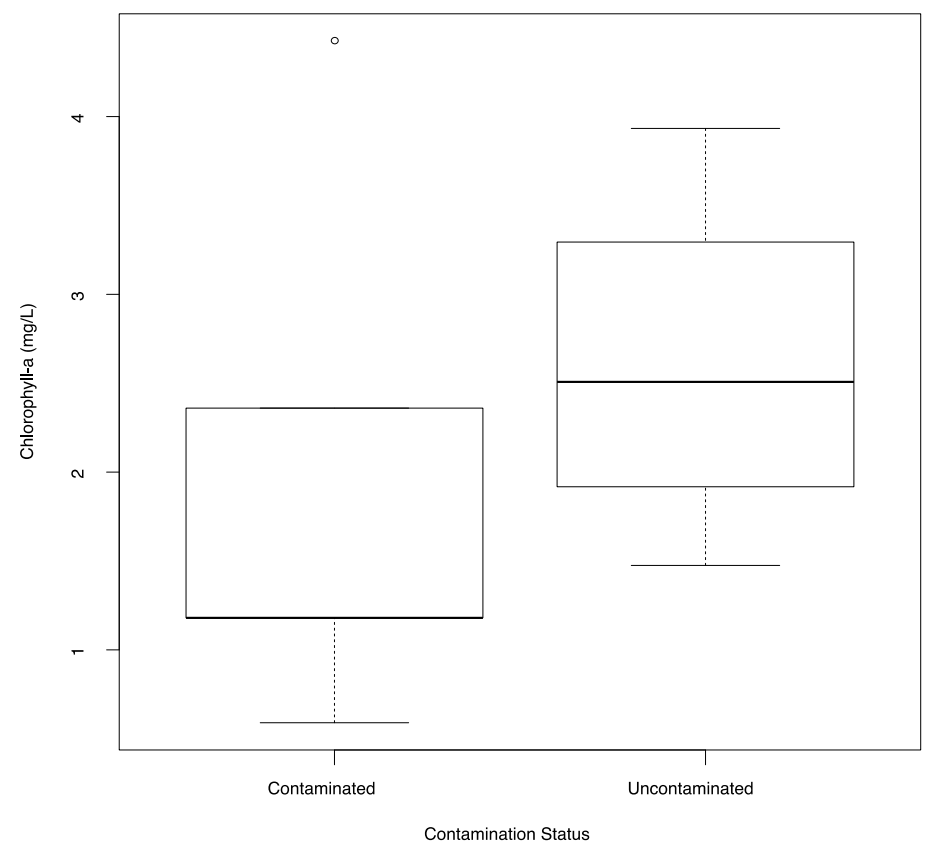

Supplementary Figure 3-2: Box and whisker plot showing the difference in means between surface water chlorophyll-a (mg/L) concentration in lakes classified as contaminated (6) and uncontaminated (4). Relationship determined to be not statistically significant $(\mathrm{p}=0.19)$. 


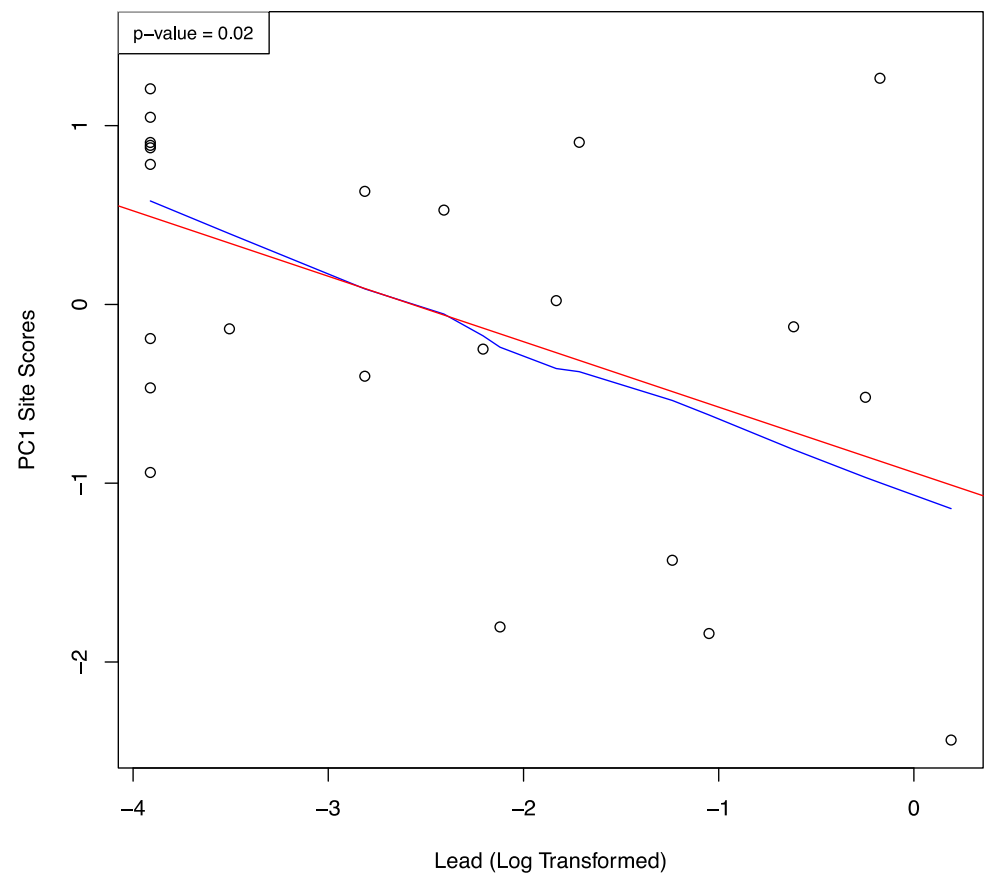

Supplementary Figure 3-3: Scatterplot of PC1 site scores from the 24-lake gradient versus lead concentrations in lakes from the Cobalt, Ontario region.

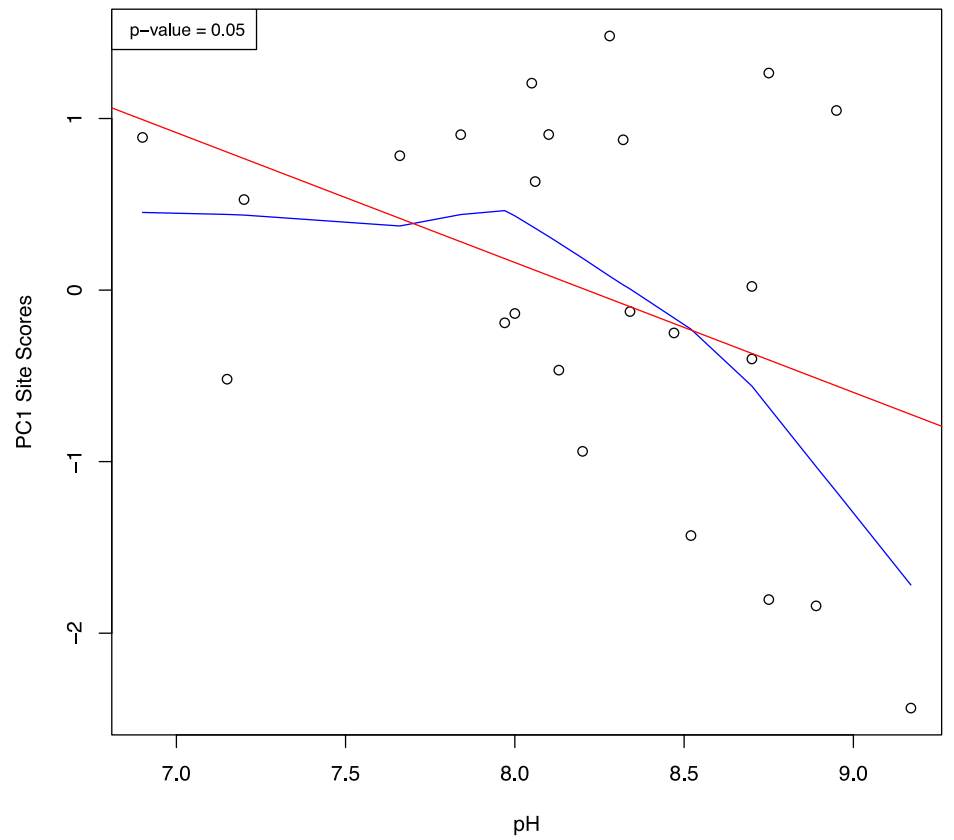

Supplementary Figure 3-4: Scatterplot of PC1 site scores from the 24-lake gradient versus pH in lakes from the Cobalt, Ontario region. 


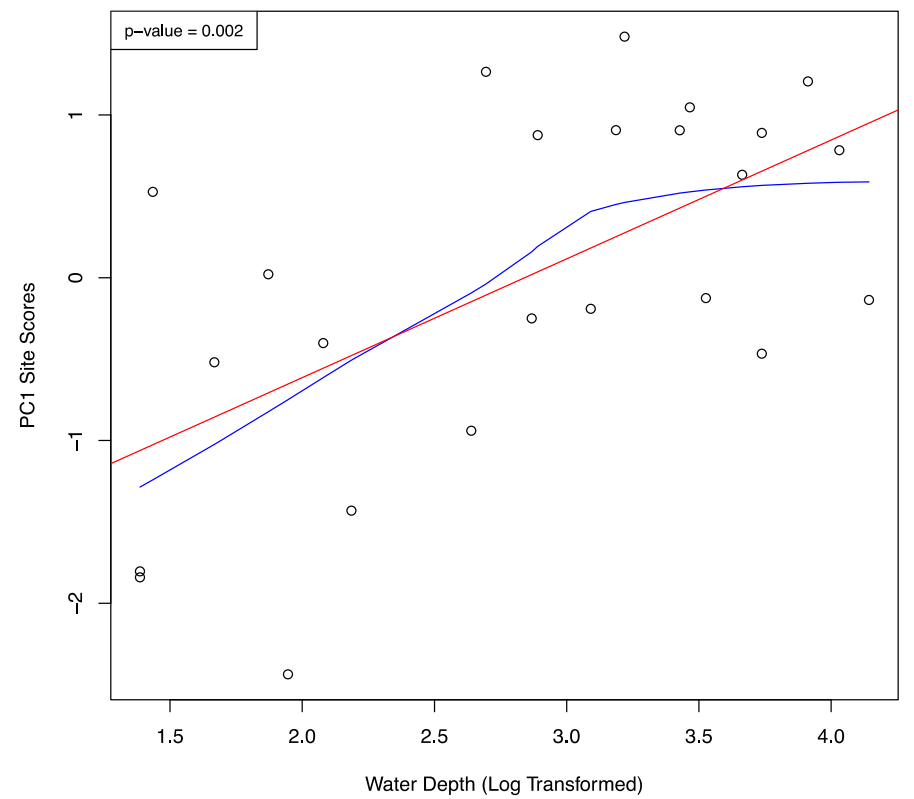

Supplementary Figure 3-5: Scatterplot of PC1 site scores from the 24-lake gradient versus water depth in lakes from the Cobalt, Ontario region.

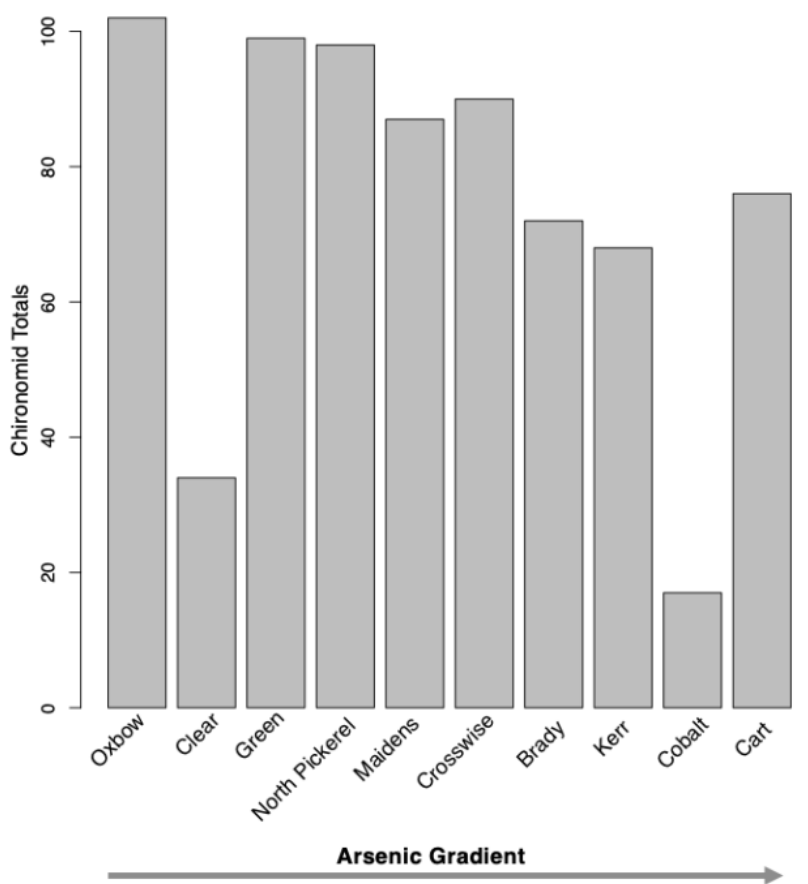

Supplementary Figure 3-6: Barplot showing the general trend of chironomid totals decreasing in lakes with higher arsenic concentrations. 
Table 3-1: Surface water chemistry collected in 2015 from 24 lakes in the Cobalt, Ontario, Canada region. Chemical variables and individual numbers highlighted in grey indicate where a guideline has been breached. Lake contamination status indicated by $\mathrm{C}$ (contaminated) or $\mathrm{U}$ (uncontaminated).

\begin{tabular}{|c|c|c|c|c|c|c|c|c|c|c|c|c|c|c|c|c|c|c|c|c|c|c|c|c|c|}
\hline Variables & $\stackrel{\Xi}{E}$ & $\stackrel{80}{20}$ & 宂 & $\frac{0}{0}$ & 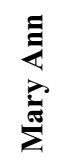 & ن. & 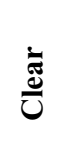 & 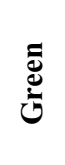 & 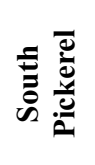 & 吾 & $\stackrel{\grave{D}}{\stackrel{\bar{\Delta}}{\bar{\Delta}}}$ & $\frac{n}{\bar{e}}$ & 兴 & $\sum_{z}^{z}$ & 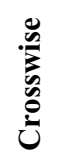 & 롤 & 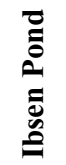 & 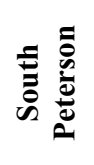 & 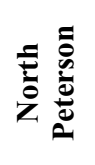 & $\underline{\square}$ & $\begin{array}{l}\frac{\pi}{\pi} \\
\frac{0}{0}\end{array}$ & 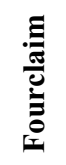 & 䒿 & Uై & $\sum_{U}$ \\
\hline $\begin{array}{c}\text { Contamination } \\
\text { Status }\end{array}$ & $\mathbf{U}$ & $\mathbf{U}$ & $\mathbf{U}$ & $\mathbf{U}$ & $\mathbf{U}$ & $\mathbf{U}$ & $\mathbf{U}$ & $\mathbf{U}$ & $\mathbf{U}$ & $\mathbf{U}$ & $\mathbf{U}$ & $\mathbf{C}$ & C & $\mathbf{C}$ & $\mathbf{C}$ & $\mathbf{C}$ & $\mathbf{C}$ & $\mathbf{C}$ & $\mathbf{C}$ & C & $\mathbf{C}$ & $\mathbf{C}$ & C & $\mathbf{C}$ & / \\
\hline Arsenic $(\mu \mathrm{g} / \mathrm{L})$ & 0.4 & 0.7 & 0.7 & 0.7 & 0.9 & 1.4 & 2 & 2.9 & 3.3 & 5 & 7.3 & 23.6 & 34 & 36.8 & 82.4 & 140 & 142 & 297 & 312 & 348 & 495 & 542 & 635 & 972 & 5 \\
\hline $\begin{array}{c}\text { Water Depth } \\
\text { (m) }\end{array}$ & 2.4 & 1.2 & 15.2 & 10.4 & 7.4 & 4.3 & 12.8 & 7.6 & 5.4 & 4.5 & 9.8 & 11.9 & 9.4 & 1.3 & 19.2 & 2.1 & 6.7 & 2.0 & 1.6 & 12.8 & 1.2 & 5.5 & 2.7 & 17.2 & I \\
\hline pH & 8.13 & 6.9 & 9.17 & 7.15 & 7.2 & 8.28 & 8.05 & 8.47 & 8.52 & 8.7 & 8.75 & 7.84 & 8.06 & 8 & 8.1 & 8.7 & 8.75 & 8.32 & 7.97 & 8.95 & 8.34 & 8.2 & 7.66 & 8.89 & $6.5-9$ \\
\hline Lead $(\mu \mathrm{g} / \mathrm{L})$ & 0.02 & 0.02 & 1.21 & 0.78 & 0.09 & 0.02 & 0.02 & 0.11 & 0.29 & 0.16 & 0.12 & 0.02 & 0.06 & 0.03 & 0.18 & 0.06 & 0.84 & 0.02 & 0.02 & 0.02 & 0.54 & 0.02 & 0.02 & 0.35 & 1 \\
\hline$\underset{(\mu \mathrm{g} / \mathrm{L})}{\text { Aluminum }}$ & 70 & 40 & 60 & 70 & 40 & 20 & 10 & 30 & 40 & 30 & 50 & 20 & 30 & 30 & 40 & 20 & 70 & 10 & 10 & 10 & 70 & 20 & 20 & 20 & Variable \\
\hline $\begin{array}{c}\text { Cadmium } \\
(\mu \mathrm{g} / \mathrm{L})\end{array}$ & 0.02 & 0.02 & 0.12 & 0.02 & 0.02 & 0.02 & 0.02 & 0.02 & 0.02 & 0.02 & 0.02 & 0.02 & 0.02 & 0.02 & 0.02 & 0.02 & 0.37 & 0.02 & 0.02 & 0.04 & 0.41 & 0.02 & 0.02 & 0.02 & 0.09 \\
\hline $\begin{array}{c}\text { Chloride } \\
\text { (mg/L) }\end{array}$ & 0.5 & 0.6 & 0.5 & 0.5 & 0.5 & 0.5 & 30.9 & 17.6 & 0.6 & 0.6 & 0.5 & 10.6 & 0.5 & 0.5 & 0.5 & 0.6 & 0.5 & 0.8 & 0.8 & 1.1 & 22.1 & 0.5 & 0.5 & 0.5 & 120 \\
\hline $\begin{array}{c}\text { Chromium } \\
(\mu \mathrm{g} / \mathrm{L})\end{array}$ & 2 & 2 & 2 & 2 & 2 & 2 & 2 & 2 & 2 & 2 & 2 & 2 & 0.2 & 2 & 2 & 2 & 3 & 2 & 2 & 2 & 3 & 2 & 2 & 2 & $1-8.9$ \\
\hline Cobalt $(\mu \mathrm{g} / \mathrm{L})$ & 0.1 & 0.1 & 0.2 & 0.1 & 0.1 & 0.1 & 0.1 & 0.1 & 0.1 & 0.1 & 0.3 & 0.1 & 0.2 & 1.8 & 0.3 & 1.1 & 10.5 & 1 & 0.9 & 624 & 2.7 & 0.8 & 0.1 & 1.7 & 1 \\
\hline Copper $(\mu \mathrm{g} / \mathrm{L})$ & 0.1 & 0.2 & 1.5 & 0.1 & 0.1 & 0.1 & 0.1 & 0.1 & 0.9 & 0.5 & 0.7 & 0.6 & 0.7 & 0.3 & 1.2 & 0.1 & 1.5 & 1.1 & 2.1 & 0.9 & 2.3 & 0.1 & 0.1 & 1.6 & 2 \\
\hline Iron $(\mu \mathrm{g} / \mathrm{L})$ & 174 & 35 & 5 & 37 & 67 & 9 & 12 & 61 & 15 & 14 & 52 & 5 & 36 & 21 & 31 & 51 & 251 & 22 & 22 & 5 & 188 & 38 & 5 & 45 & 300 \\
\hline $\begin{array}{c}\text { Potassium } \\
(\mathrm{mg} / \mathrm{L})\end{array}$ & 0.3 & 0.2 & 0.3 & 0.2 & 0.3 & 0.2 & 0.4 & 0.4 & 0.2 & 0.2 & 0.3 & 0.3 & 0.3 & 0.2 & 0.3 & 0.6 & 0.2 & 0.8 & 0.8 & 1.2 & 1 & 0.7 & 0.3 & 0.9 & I \\
\hline Silver $(\boldsymbol{\mu g} / \mathbf{L})$ & 0.02 & 0.02 & 0.03 & 0.02 & 0.02 & 0.02 & 0.02 & 0.02 & 0.02 & 0.02 & 0.06 & 0.02 & 0.02 & 0.02 & 0.02 & 0.02 & 0.03 & 0.02 & 0.02 & 0.02 & 0.02 & 0.02 & 0.02 & 0.05 & 0.25 \\
\hline Sodium (mg/L) & 2 & 0.9 & 0.6 & 0.8 & 0.9 & 0.7 & 19.9 & 12.6 & 0.7 & 0.8 & 0.8 & 2 & 0.7 & 0.7 & 0.8 & 0.9 & 2.3 & 1.3 & 1.4 & 3.5 & 17.4 & 0.9 & 0.8 & 1.8 & 1 \\
\hline $\begin{array}{c}\text { Sulphate } \\
\text { (mg/L) }\end{array}$ & 3 & 2 & 1 & 3 & 2 & 3 & 5 & 3 & 5 & 6 & 2 & 4 & 3 & 3 & 3 & 7 & 3 & 6 & 6 & 34 & 10 & 4 & 4 & 6 & I \\
\hline Zinc $(\mu \mathrm{g} / \mathrm{L})$ & 53 & 5 & 9 & 16 & 5 & 9 & 5 & 5 & 5 & 5 & 25 & 6 & 12 & 20 & 9 & 5 & 32 & 12 & 5 & 53 & 38 & 8 & 12 & 5 & 7 \\
\hline
\end{tabular}


Table 3-2: Surface water chemistry collected in 2017 from 10 lakes in the Cobalt, Ontario, Canada region which were found to be less than $70 \%$ correlated with one another. Chemical variables and individual numbers highlighted in grey indicate when a guideline has been breached.

\begin{tabular}{|c|c|c|c|c|c|c|c|c|c|c|c|}
\hline Variables & $\frac{8}{8}$ & $\frac{\grave{\Xi}}{\circlearrowright}$ & $\underset{\circlearrowright}{0}$ & 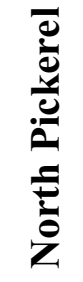 & $\underset{\sum}{\stackrel{0}{\frac{\pi}{\sigma}}}$ & $\frac{\mathscr{0}}{\mathscr{E}}$ & 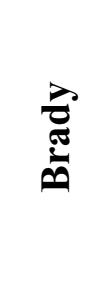 & $\ddot{\partial}$ & $\frac{\varpi}{\stackrel{\Xi}{0}}$ & $\underset{\mho}{\varpi}$ & 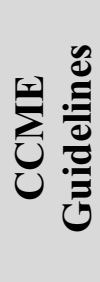 \\
\hline Contamination Status & $\mathbf{U}$ & $\mathbf{U}$ & $\mathbf{U}$ & $\mathbf{U}$ & $\mathbf{C}$ & $\mathbf{C}$ & $\mathbf{C}$ & $\mathbf{C}$ & $\mathbf{C}$ & $\mathbf{C}$ & I \\
\hline Arsenic $(\mu \mathrm{g} / \mathrm{L})$ & 0.9 & 3.2 & 3.8 & 4.9 & 21.6 & 89.6 & 142.3 & 328.7 & 505 & 1113.3 & \multirow[t]{2}{*}{5} \\
\hline Water Depth (m) & 8.5 & 1.6 & 19.8 & 6.1 & 7.3 & 4.8 & 26.2 & 7.6 & 2.6 & 8.7 & \\
\hline Chlorophyll-a (mg/L) & 2.7 & 3.9 & 1.5 & 2.4 & 1.2 & 1.2 & 4.4 & 2.4 & 1.2 & 0.6 & l \\
\hline Calcium (mg/L) & 3.1 & 25.1 & 18.7 & 25.9 & 12.4 & 19.7 & 28.3 & 49.1 & 41.1 & 23.9 & l \\
\hline Cobalt ( $\mu \mathrm{g} / \mathrm{L})$ & 0.1 & 0.8 & 2 & 3.6 & 1.1 & 0.7 & 0.7 & 905.7 & 2.2 & 2.3 & l \\
\hline Iron $(\mu g / L)$ & 45 & 10 & 63.3 & 19.7 & 12.3 & 42.7 & 19.3 & 5.00 & 19.7 & 75.3 & 300 \\
\hline Lead $(\mu \mathrm{g} / \mathrm{L})$ & 0.1 & 0.6 & 0.1 & 0.9 & 0 & 1 & 1.9 & 0.1 & 0.1 & 0.6 & 1 \\
\hline $\mathbf{p H}$ & 8.7 & 8.4 & 8.1 & 9 & 8.3 & 8.8 & 8.5 & 8.9 & 8.5 & 8.9 & $6.5-9$ \\
\hline
\end{tabular}


Supplementary Table 3-1: Bio-indicator taxa short forms used in ordination plots.

\begin{tabular}{|c|c|c|c|}
\hline \multicolumn{4}{|l|}{ Diatoms } \\
\hline Full Name & Abbreviation & Full Name & Abbreviation \\
\hline Achnanthidium minutissimum & A.minu. & Lindavia bodanica & L. bod. \\
\hline Aulocoseira ambigua & Au. amb. & Lindavia michiganiana & L. mich. \\
\hline Aulocoseira distans & Au. dis. & Navicula cryptotenella & N. crypt. \\
\hline Brachysira brebissonii & B. breb. & Navicula libonensis & N. lib. \\
\hline Brachysira vitrea & B. vit. & Nitzchia fonticola & Ni. font. \\
\hline Caloneis silicula & C. sil. & Pantocsekiella ocellata & Pa. oce. \\
\hline Denticula kuetzingii & De. kuetz. & Pantocsekiella rossii & Pa. ross. \\
\hline Diploneis modica & D. mod. & Pinnularia microstauron & Pi. micro. \\
\hline Diploneis oblongella & D. obl. & Psammothidium marginulatum & Ps. marg. \\
\hline Discotella stelligera & Di. stell. & Psammothidium ventrale & Ps. ven. \\
\hline Encyonopsis descripta & E. des. & Pseudostaurosira brevistriata & P. brev. \\
\hline Encyonopsis microcephala & E. micro. & Pseudostaurosira parasitica & P. para. \\
\hline Fragilaria capucina & F. cap. & Sellaphora pupula & Se. pup. \\
\hline Fragilaria exigua & F. exi. & Staurosira construens & St. cons. \\
\hline Fragilaria tenera & F. ten. & Staurosirella pinnata & S. pin. \\
\hline Gomphonema gracile & G. grac. & Tabellaria flocculosa & T. floc. \\
\hline \multicolumn{4}{|l|}{ Cladocera } \\
\hline Full Name & Abbreviation & Full Name & Abbreviation \\
\hline Acantholeberis curvirostris & Ac. curv. & Camptocercus species & Camp. \\
\hline Acroperus species & Acro. & Chydorus brevilabris sphaericus & Ch. Brev. \\
\hline Alona affinis & Al. aff. & D. longspina complex & D. long. \\
\hline Alona circumfimbriata rectangula & Al. circ. & D. pulex complex & D. pul. \\
\hline Alona guttata & Al. gutt. & Eurycercus species & Eury. \\
\hline Alona quadrangularia & Al. quad. & Kurzia latissima & K. lati. \\
\hline Alona rustica & Al. rust. & Latona parviremis & La. Parv. \\
\hline Alonella excisa & Alo. Ex. & Ophyryoxus gracilis & O. grac. \\
\hline Alonella nana & Alo. Nan. & Pleuroxus trigonellus & Pl. trig. \\
\hline Alonella pulchella & Alo. Pul. & Sida crystalline americana & Sid. Crys. \\
\hline
\end{tabular}




\begin{tabular}{|c|c|c|c|}
\hline Bosmina sp. & Bos. & & \\
\hline \multicolumn{4}{|l|}{ Chironomids } \\
\hline Full Name & Abbreviation & Full Name & Abbreviation \\
\hline Chironomus anthracinus-type & Chiro. Anth. & Microspectra pallidula-type & Micro. Pall. \\
\hline Chironomus plumosus-type & Chiro. Plum. & Microspectra.contracta.type & Micro. Cont. \\
\hline Cladopelma lateralis & C. later. & Microspectra.radialis.type & Micro. Rad. \\
\hline Cladotanytarsus mancus & Clad. Man. & Microtendipes pedullus-type & Mic. Ped. \\
\hline Corynoneura coronate-type & Cory. Coro. & Orthocladius type-I & Ortho. \\
\hline Corynoneura type $A$ & Cory. A. & Parakiefferiella bathophila-type & Par. Bath. \\
\hline Cricotopus coronate-type & Cr. Coro. & Paratanytarsus & Para. \\
\hline Cricotopus othrocaldius & Cr. Oth. & Paratanytarsus austriacus-type & Para. Aus. \\
\hline Cryptochironomis & Crypto. & Polypedilum nubeculosum-type & Poly. Nub. \\
\hline Dicrotendipes nervosus-type & Dicro. Ner. & Pseudochironomus & Pseudo. \\
\hline Einfeldia dissidens-type & Ei. Diss. & Tanypodinae & Tany. \\
\hline Einfeldia pagana-type & Ei. Pag. & Tanytarsus lactescens-type & Tany. Lact. \\
\hline Endochironomus albipennis-type & Endo. Alb. & Tanytarsus lugens-type & Ta. lug. \\
\hline Glypototendipes pallens-type & Glypo. Pall. & Unknown & Unk. \\
\hline \multicolumn{4}{|l|}{ Zooplankton } \\
\hline Full Name & Abbreviation & Full Name & Abbreviation \\
\hline Cladocera bosminidae & Bos. & Copepoda ergasilidae & Co. erga. \\
\hline Cladocera holopedidae & Cl. Holo. & Crustacea ostracoda & Cr. Ostra. \\
\hline Cladocera sididae & Cl. Sid. & Hydracarina & Hydra. \\
\hline Copepoda calanoida [order] & Co. cala. & Rotifera brachionidae & R. brach. \\
\hline Copepoda cyclopidae & Co. cyc. & & \\
\hline
\end{tabular}




\section{GENERAL CONCLUSIONS}

This thesis investigated the potential impacts of century-old, arsenic-rich, mine tailings on aquatic ecosystem community health in lakes from Cobalt, Ontario, Canada. The historical Cobalt and Silver Centre mining camps represent important study sites for the investigation of the long-term (decades and longer) impacts from legacy contamination events. The main objective of this thesis was to contribute to the growing body of research regarding the long-term impacts of arsenic, and other mining-related pollutants, on exposed aquatic lake ecosystems.

The results of this thesis indicated that despite the long duration of exposure and total quantity of the metalloid's presence, arsenic is not a significant driver of biological community structure among lakes in and around Cobalt. Of the four main bio-indicators studied in this chapter, only the diatom communities were able to successfully identify alternative influential variables of statistical significance, likely due to the larger sample size of lakes employed in the diatom study. They were water depth, lead, and $\mathrm{pH}$. It is therefore, more likely that morphometry and natural chemistry are more important than arsenic in influencing the biology of these lakes. These results are important in the implementation of future environmental management strategies when it comes to anthropogenically-sourced contaminant exposure in impacted Canadian waterbodies.

Future research concerned with the long-term impacts of arsenic exposure in lakes could quantify and investigate the specific species of arsenic present in both contaminated and uncontaminated lakes in the area in order to increase our understanding of how arsenic speciation effects the biological community. This, in combination with an analysis of the redox conditions present at the surface-water interface of mine tailings in these lakes and a reduction in the overall variability between study sites (i.e., water depth, $\mathrm{pH}$, nutrient inputs, etc.), could be fundamental 
in identifying which lakes are host to tailings acting as either sinks or sources of arsenic to the rest of the system. This is particularly important given the results of Sprague et al. (2016), which concluded that mine tailings laden with a variety of different heavy metals and contaminants are continuing to migrate into previously uncontaminated systems in the region.

Another important component, which could be explored in future research in the area, are the exposure ranges and thresholds of biological communities in impacted lakes. It would be beneficial to begin cataloguing the response behaviors of exposed biota to a variety of different chemical variables, including different species of arsenic, in order to create a better understanding of how impacted ecosystems adapt to changes in inputs of specific contaminants of concern. This would allow for observations between the potential difference in results garnered from in lab short-term studies versus in situ long-term studies. This would also allow for comparison between paleolimnological and more traditional ecotoxicological research, while contributing to the up and coming field of paleo-ecotoxicology. This kind of multi-disciplinary approach allows for project participants to learn the best practices from a variety of different fields, and implement more practical and useful frameworks for future research.

In conclusion, the research presented in this thesis is foundational for the use of future spatial gradient studies interested in investigating anthropogenically-sourced contaminants in Canadian lakes. The main results of this thesis indicate that lake morphometry and water chemistry controls have a larger impact on the biological structure of the study lakes than arsenic, despite the high arsenic concentrations and exposure time in the Cobalt region. These results are important for consideration in the implementation of future environmental management strategies for water bodies which have been impacted by historical mining activities, especially in terms of setting biological restoration targets for lakes. The results of this 
thesis highlight the need for better understanding of how metal(loid)s and other environmental pollutants interact with and behave in aquatic environments, specifically between different lake systems. Therefore, more research is needed before creating and implementing accurate, blanket environmental guidelines in Canada. 


\section{REFERENCES}

Aggett, J., Roberts, L. S. (1986). Insight into the mechanism of accumulation of arsenate and phosphate in hydro lake sediments by measuring the rate of dissolution with ethylenediaminetetracetic acid. Environmental Science and Technology, 20:183-186.

Alexander, M. (2000). Aging, bioavailability, and overestimation of risk from environmental pollutants. Environmental Science and Technology, 34:4259-4265.

Aminot, A., Rey, F. (2000). Standard procedure for the determination of chlorophyll- $a$ by spectroscopic methods. Prepared for: International Council for the Exploration of the Sea. ISSN 0903-2606.

Anderson, P. (1993). Cobalt mining camp tailings inventory, Cobalt, Ontario. [Unpublished Report]. Ministry of Northern Development and Mines: 196.

Andrade, C. F., Jamieson, H. E., Kyser, T. K., Praharaj, T., Fortin, D. (2010). Biogeochemical redox cycling of arsenic in mine-impacted lake sediments and co-existing pore waters near Giant Mine, Yellowknife Bay, Canada. Applied Geochemistry, 25(2):199-211.

Armitage, P. D., Cranston, P. S., Pinder, L. C. V. (1995). The Chironomidae: Biology and Ecology of Non-Biting Midges. 572, Chapman \& Hall.

Austin, A., Munteanu, N. (1984). Evaluation of changes in a large oligotrophic wilderness park lake exposed to mine tailings effluents for 14 years: the phytoplankton. Environmental Pollution (Series A), 33:39-62.

Baird, C., Cann, M. (2012). Environmental chemistry. Ed. 5. New York, NY: W. H. Freeman and Company.

Baldwin, D. O., Duke, D. F. (2005). "A grey wee town": An environmental history of early silver mining at Cobalt, Ontario. Urban History Review, 34(1): 71-87.

Barnes, M. (1986). Fortunes in the ground: Cobalt, Porcupine \& Kirkland Lake. Boston Mills Press: Erin, Ontario.

Barral-Fraga, L., Morin, S., Rovira, M. D. M., Urrea, G., Magellan, K., Guasch, H. (2016). Short-term arsenic exposure reduces diatom cell size in biofilm communities. Journal of Environmental Science Pollution Research, 23:4257-4270.

Battarbee, R.W., Smole, J. P., Stoermer, E. F. (2010). Diatoms as indicators of surface-water acidity. In The diatoms: applications for the environmental and earth sciences. $2^{\text {nd }} \mathrm{Ed}$. Cambridge University Press: Cambridge. pp. 85-128.

Beauchemin, S., Kwong, J. (2006). Impact of redox conditions on arsenic mobilization from tailings in a wetland with neutral drainage. Environmental Science and Technology,

40(20):6297-6303. 
Berry, L.G., Mason, B., Dietrich, R. V. (1983). Mineralogy. Concepts, descriptions, determinations. W.H. Freeman and Company, San Francisco.

Biesinger, K.E., Christensen. G.M. (1972). Effects of various metals on survival, reproduction, and metabolism of Daphnia magna. Canadian Journal of Fisheries and Aquatic Sciences, 29:125.

Birge, W, J., Hudson, J. E., Black, J. A., Westerman, A. G. (1979). Embryo-larval bioassays on inorganic coal elements and in situ biomonitoring of coal-waste effluents. In: Surface mining and fish/wildlife needs in the eastern United States, D.E. Samuel, J.R. Stauffer, C.H. Hocutt, and W.T. Mason Jr., eds., pp. 97-104. Fish and Wildlife Service, Office of Biological Services. FWS/OBS-78/81. U.S. Government Printing Office, Washington, DC.

Birks, H. J. B. (2010). Numerical methods for the analysis of diatom assemblage data. In Smol, J.P. \& E. F. Stoermer (eds), The Diatoms: Applications for the Environmental and Earth Sciences. Cambridge University Press, Cambridge, United Kingdom: 23-54.

Black, A. R., 1993. Predator-induced phenotypic plasticity in Daphnia pulex: Life history and morphological responses to Notonecta and Chaoborus. Limnology and Oceanography, 38: 986996.

Bochove, D. (2017, October 31). The Canadian ghost town that Tesla is bringing back to life: Renewed demand for cobalt, the metal, is breathing new life into Cobalt, the town. Bloomberg. Accessed online on January $19^{\text {th }} 2019$, at: $<$ https://www.bloomberg.com/news/features/2017-1031/the-canadian-ghost-town-that-tesla-is-bringing-back-to-life $>$.

Borgmann, U., R. Cove, Loveridge, C. (1980). Effects of metals on the biomass production kinetics of freshwater copepods. Canadian Journal of Fisheries and Aquatic Sciences, 37:567575.

Boyle, R.W., Jonasson, I. R. (1973). The geochemistry of arsenic and its use as an indicator element in geochemical prospecting. Journal of Geochemical Exploration. 2(3), 251-296.

Brännvall, M., Bindler, R., Renberg, I., Emteryd, O., Bartnicki, J., Billström, K. (1999). The medieval metal industry was the cradle of modern large-scale atmospheric lead pollution in northern Europe. Environmental Science and Technology, 33(24):4391-4395.

Brodersen, K.P., Quinlan, R. (2006). Midges as paleoindicators of lake productivity, eutrophication and hypolimnetic oxygen. Quaternary Science Reviews, 25:1995-2012.

Brooks, S. J., Langdon, P.G., Heiri, O. (2007). The identification and use of palaeartic chironomidae larvae in paleoecology: QRA technical guide no. 10. Quaternary Research Association. London, UK. 276 pp.

Brown, B. T., Rattigan, B. M. (1979). Toxicity of soluble copper and other metal ions to Elodea Canadensis. Environmental Pollution, 1970(20): 303-314. 
Brugam, R. B., McKeever, K., Kolesa, L. (1998). A diatom-inferred water depth reconstruction for an Upper Pennisula, Michigan, lake. Journal of Paleolimnology, 20:267-276.

Bryant, V., Newbery, D. M., McLusky, D. S., Campbell, R. (1985). Effect of temperature and salinity on the toxicity of arsenic to three estuarine invertebrates (Corophium volutator, Macoma balthica, Tubifex costatus). Marine Ecology Progress Series, 24(1/2): 129-137.

Cai, Y., Cabrera, J. C., Georgiadis, M., Jayachandran, K. (2002). Assessment of arsenic mobility in the soils of some golf courses in South Florida. Science of the Total Environment, 291:123134.

Canadian Council of Ministers of the Environment [CCME]. (2003). Canadian water quality guidelines for the protection of aquatic life: Summary Table. Updated In: Canadian environmental quality guidelines. (1999). Canadian Council of Ministers of the Environment. Winnipeg.

Canadian Council of Ministers of the Environment [CCME]. (2001). Canadian water quality guidelines for the protection of aquatic life: Arsenic. Updated In: Canadian environmental quality guidelines. (1999). Canadian Council of Ministers of the Environment. Winnipeg.

Canadian Council of Ministers of the Environment [CCME]. (1991). Appendix IX-A protocol for the derivation of water quality guidelines for the protection of aquatic life (April 1991). In: Canadian water quality guidelines, Canadian Council of Resource and Environment Ministers. 1987. Prepared by the Task Force on Water Quality Guidelines.

Canadian Council of Ministers of the Environment [CCME]. (1997). Appendix XXIIICanadian water quality guidelines: Updates (June 1997), arsenic, bromacil, carbaryl, chlorpyrifos, deltamethin, and glycols. In: Canadian water quality guidelines, Canadian Council of Resource and Environment Ministers. 1987. Prepared by the Task Force on Water Quality Guidelines.

Canadian Public Health Association [CPHA]. (1977). Taskforce on arsenic. Final Report. Yellowknife, Northwest Territories: Canadian Public Health Association.

Canfield, T., J., Kemble, N., E., Brumbaugh, W., G., Dwyer, F., J., Ingersoll, C., G., Fairchild, J., F. (1994). Use of benthic invertebrate community structure and the sediment quality triad to evaluate metal-contaminated sediment in the Upper Clark Fork River, Montana. Journal of Environmental Toxicology and Chemistry, 13:1999 - 2012.

Casiot, C., Ujevic, M., Munoz, M., Seidel, J. L., Elbaz-Poulichet, F. (2007). Antimony and arsenic mobility in a creek draining an antimony mine abandoned 85 years ago (upper Orb basin, France). Applied Geochemistry, 22:788-798.

Cattaneo, A., Couillard, Y., Wunsam, S., Courcelles, M. (2004). Diatom taxonomic and morphological changes as indicators of metal pollution and recovery in Lac Dufault (Québec, Canada). Journal of Paleolimnology, 32: 163-175. 
Charles, D. F., Whitehead, D. R. (1986). The PIRLA project: paleoecological investigations of recent lake acidification. Hydrobiologia, 143(1): 13-20.

Chen, G., Shi, H., Tao, J., Chen, L., Liu, Y., Lei, G., Liu, X., Smol, P. (2015). Industrial arsenic contamination causes catastrophic changes in freshwater ecosystems. Scientific Reports, $5: 17419$.

Cockell, K. A., Hilton, J. W. (1985). Chronic toxicity of dietary inorganic and organic arsenicals to rainbow trout (Salmo gairdneri R.). Federation Proceedings, 44(4):938.

Couture, R.M., Gobeil, C., Tessier, A. (2010). Arsenic, iron and sulfur co-diagenesis in lake sediments. Geochimica et Cosmochimica Acta, 74(4):1238-1255.

Cullen, W.R., Reimer, K. J. (1989): Arsenic speciation in the environment. Chemical Reviews. 89(4), 713-764.

Cumming, B. F., Smol, J. P., Kingston, J. C., Charles, D. F., Birks, H. J. B., Camburn, K. E., Dixit, S. S., Uutala, A. J., Selle, A. R. (1992). How much acidification has occurred in Adirondack region (New York, U.S.A.) lakes since pre-industrial time? Canadian Journal of Fisheries and Aquatic Sciences, 49(1):128-141.

Dhargalkar, V. K., Verlecar, X. N. (2004). Zooplankton methodology, collection and identification - a field manual. National Institute of Oceanography. New Delhi.

Dixit, S. S., Dixit, A. S., Smol, J. P. (1991). Multivariate environmental inferences based on diatom assemblages from Sudbury (Canada) lakes. Freshwater Biology, 26:251-266.

Dixit, S. S., Smol, J. P., Kingston, J. C., Charles, D. F. (1992). Diatoms: Powerful indicators of environmental change. Environmental Science Technology, 26(1): 22-33.

Dodson, S. I. \& T. Hanazato, 1995. Commentary on effects of anthropogenic and natural organic chemicals on development, swimming behavior, and reproduction of Daphnia, a key member of aquatic ecosystem. Environmental Health Perspectives, 103: 7-11.

Doig, L. E., Schiffer, S. T., Liber, K. (2015). Reconstructing the ecological impacts of eight decades of mining, metallurgical, and municipal activities on a small boreal lake in northern Canada. Integrated Environmental Assessment Management, 11(3). 490-501.

Dumaresq, C. G. (1993). The occurrence of arsenic and heavy metal contamination from natural and anthropogenic sources in the Cobalt area of Ontario. [Master's thesis]. Carleton University, Canada.

Dumaresq, C. (2009). Cobalt Mining Legacy. Accessed online on January 24 ${ }^{\text {th }}, 2019$ at: $<$ http://www.cobaltmininglegacy.ca $>$.

Edmondson, W. T., 1957. Trophic relations of the zooplankton. Trans. am. mic. Soc. Vol. LXXVI, No. 3. 
Eisler, R. (1988). Arsenic hazards to fish, wildlife, and invertebrates: A synoptic review. (Report No. 12; Biological Report No. 85(1.12)). Laurel, Maryland: U.S. Department of the Interior, Fish and Wildlife Service.

Environment Canada. (2014). Canadian environmental quality guide- lines (CEGQ) under the Canadian Environmental Protection Act: water quality guidelines for the protection of aquatic life. Prepared by Environment Canada.

Environment and Climate Change Canada [ECCC]. (2019). Historical climate data. Government of Canada. Retrieved from:

$<$ http://climate.weather.gc.ca/historical_data/search_historic_data_e.html>.

Environmental Protection Agency [EPA]. (1980). Ambient water quality criteria for arsenic. U.S. Environmental Protection Agency. Report No. 440/5-80-021.

Environmental Protection Agency [EPA]. (1985). Ambient water quality criteria for arsenic 1984. U.S. Environmental Protection Agency Report. 440/5-84-033. 6.

Falasco, E., Bona, F., Hoffman, G., Ector, L. (2009). Diatom teratological forms and environmental alterations: a review. Hydrobiologia, 623:1-35.

Fargasova, A. (1993). Effect of five toxic metals on the alga Scenedesmus quadricus. Biologia (Bratislava) 48(3):301-304.

Ferrington, L. C. (2008). Freshwater Animal Diversity Assessment in Hydrobiology. Balian, E. V., Lévêque, C., Segers, H., Martens, K. Springer Netherlands.

Ferrington, L. C., Berg, M. B., Coffman, W. P. (2008). An Introduction to the Aquatic Insects of North America. Merritt, R. W., Cummins, K. W., Berg, M. B. Kendall/Hunt Publishing Company.

Frisch, D., Morton, P. K., Chowdhury, P. R., Culver, B. W., Colbourne, J. K., Weider, L. J., Jeyasignh, P. D. (2014). A millennial-scale chronicle of evolutionary responses to cultural eutrophication in Daphnia. Ecology Letters, 17(3): 360-368.

Friedman, G. (2018, May 24). How dreams of 'Mount Cobalt' are dividing an old mining town: as cobalt prices spike, some support levelling and gutting Cobalt, Ontario, for mining's return and economic prosperity, but others find the prospect 'heartbreaking'. Financial Post. Accessed online on January $19^{\text {th }}, 2019$, at: $<$ https://business.financialpost.com/commodities/mining/howdreams-of-mount-cobalt-are-dividing-an-old-mining-town $>$.

Galloway, J. M., Palmer, M., Jamieson, H. E., Patterson, R. T., Nasser, N., Falck, H., Macumber, A. L., Goldsmith, S. A., Sanei, H., Normandeau, P., Hadlari, T., Roe, H. M., Neville, L. A., Lemay. D. (2015). Geochemistry of lakes across ecozones in the Northwest Territories and implications for the distribution of arsenic in the Yellowknife region. Part 1: sediments. Geological Survey of Canada. Open File: 7908. 
Galloway, J. M., Swindles, G. T., Jamieson, H. E., Palmer, M., Parsons, M. B., Sanei, H., Macumber, A. L., Patterson, R. T., Falck, H. (2018). Organic matter control on the distribution of arsenic in lakes sediments impacted by $\sim 65$ years of gold ore processing in subarctic Canada. Science of the Total Environment, (622-623):1668-1679.

Gamma-Flores, J. L., Sarma, S. S. S., Nandini, S. (2005). Interaction among copper toxicity, temperature and salinity on the population dynamics of Brachionus rotuniformis (Rotifera). Hydrobiologia, 546:559-568.

Gaskova, O. J., Bessonova, E. P., Bortnikova, S. B. (2003). Leaching experiments on trace element release from the arsenic bearing tailings of Khuvo-Aksy (Tuba Republic, Russia). Applied Geochemistry, 18:1361-1371.

Geerts, A. N., Vanoverbeke, J., Vanschoenwinkel, B., Van Doorlaer, W., Feuchtmayr, H., Atkinson, D., Moss, B., Davidson, T. A., Sayer, C. D., De Meester, L. (2015). Rapid evolution of thermal tolerance in the water flea Daphnia. Nature Climate Change, 5(7): 665-668.

Gillis, P. L., McGeer, J. C., Mackie, G. L., Wilkie, M. P., Ackerman, J. D. (2010). The effect of natural dissolved organic carbon on the acute toxicity of copper to larval freshwater mussels (Glochidia). Environmental Toxicology and Chemistry, 29(11): 2519-2528.

Glew, J. R. (1988). A portable extruding device for close interval sectioning of unconsolidated core samples. Journal of Paleolimnology, 1:235-239.

Glew, J. R. (1989). A new trigger mechanism for sediment samplers. Journal of Paleolimnology, 2:241-243.

Gonçalves, S., Kahlert, M., Almeida, S. F. P., Figueria, E. (2018). Assessing Cu impacts in freshwater diatoms: biochemical and metabolomics responses of Tabellaria flocculosa (Roth) Kützing. Science of the Total Environment, 625:1234-1246.

Government of Canada. (1993). Arsenic and its compounds. Canadian Environmental Protection Act Priority Substances List Supporting Document. Health and Welfare Canada and Environment Canada, Ottawa.

Greffard, M. H., Saulnier-Talbot, É. Gregory-Eaves, I. (2012). Sub-fossil chironomids are significant indicators of turbidity in shallow lakes of northeaster USA. Journal of Paleolimnology, 47: 561-581.

Hairston, N. G., Jr. Lampert, W., Caćeres, C. E., Holtmeier, C. L., Weider, L. J., Gaedke, U., Fischer, J. M., Fox, J. A., Post, D. M. (1999). Lake ecosystems: rapid evolution revealed by dormant eggs. Nature, 401, 446.

Hakånson, L. (1977). The influence of wind, fetch, and water depth on the distribution of sediments in Lake Vänern, Sweden. Canadian Journal of Fisheries and Aquatic Sciences, 14:397-412. 
Hamilton, D. P., Mitchell, S. F., (1997). Wave-induced shear stresses, plant nutrients and chlorophyll in seven shallow lakes. Freshwater Biology, 38:159-168.

Haney, J. F. (2013). An image-based key to the zooplankton of North America. Version 5.0. University of New Hampshire Centre for Freshwater Biology. $<\mathrm{cfb}$.unh.edu $>$.

Harper, P.P., Cloutier, L. (1986). Spatial structure of the insect community of a small dimictic lake in the Laurentians (Québec). Internationale Revue der gesamten Hydrobiologie und Hydrographie, 71:655-685.

Havel, J. E., Medley, K. A. (2006). Biological invasions across spatial scales: Intercontinental, regional, and local dispersal of cladoceran zooplankton. Biological Invasions, 8, 459-473.

He, W., Megharaj, M., Naidu, R. (2009). Toxicity of tri- and penta-valent arsenic, alone and in combination, to the cladoceran Daphnia carinata: the influence of microbial transformation in natural waters. Journal of Environmental Geochemistry and Health, 31:133-141.

Hessen, D. O., Faafeng, B. A., Andersen, T. (1995). Replacement of herbivore zooplankton species along gradients of ecosystem productivity and fish predation pressure. Canadian Journal of Fisheries and Aquatic Sciences, 52:733-742.

Hood, R. D. (1985). Cacodylic acid: agricultural uses, biologic effects, and environmental fate. VA Monograph. Supporting. Documents, U.S. Government Printing Office, Washington D.C. 20402.

Houben, A. J., R. D’Onofrio, S. V. Kokelj, Blais, J. M. (2016). Factors affecting elevated arsenic and methyl mercury concentrations in small shield lakes surrounding gold mines near the Yellowknife, NT, (Canada) region. PLoS ONE, 11:e0150960.

Islam, F. S., Gault, A. G., Boothman, C., Polya, D. A., Charnock, J. M., Chatterjee, D., Lloyd, J. R. (2004). Role of metal-reducing bacteria in arsenic release from Bengal delta sediments. Nature, 430: 68-71.

Jambor, J.L. (1971). General geology. In: Berry, L.G. (Ed.), The Silver- Arsenide Deposits of the Cobalt-Gowganda Region, Ontario. Canadian Mineralogist, 11:12-33.

Jana, S., Sahana, S. S. (1989). Sensitivity of the freshwater fishes Clarias batrachus and Anabas testudineus to heavy metals. Environmental Ecology, 7(2): 265-270.

Janssens de Bisthoven, L. (1998). Relations between heavy metals in aquatic sediments and Chironomus larvae of Belgian Lowland rivers and their morphological deformities. Canadian Journal of Fisheries and Aquatic Sciences, (55):688-703.

Järvinen, M. \& K. Salonen, 1998. Influence of changing food web structure on nutrient limitation of phytoplankton in a highly humic lake. Canadian Journal of Fisheries and Aquatic Sciences, 55: 2562-2571. 
Jeppesen, E., Nõges, P., Davidson, T. A., Haberman, J., Nõges, T., Blank, K., Lauridsen, T. L., Søndergaard, M., Sayer, C., Laugaste, R., Johansson, L. S., Bjerring, R., Amsinck, S. L. (2011). Zooplankton as indicators in lakes: a scientific-based plea for including zooplankton in the ecological quality assessment of lakes according to the European Water Framework Directive (WFD). Hydrobiologia, 676-279.

Jeyasingham, K., Ling, N. (2000). Acute toxicity of arsenic to three species of New Zealand chironomids: Chironomus zealandicus, Chironomus sp. a and Polypedilum pavidus (Diptera, Chironomidae). Journal of Environmental Contamination and Toxicology, 64:708-715.

Jeziorski, A., Keller, B., Paterson, A. M., Greenaway, C. M., Smol, J. P. (2013). Aquatic ecosystem responses to rapid recovery from extreme acidification and metal contamination in lakes near Wawa, Ontario. Ecosystems, 16:209-223.

Johnson, W. W., Finley, M. T. (1980). Handbook of acute toxicity of chemicals to fish and aquatic invertebrates. U.S. Fish and Wildife Service/ Resource Publication No. 137.

Juárez-Franco, M. F., Sarma, S. S. S., Nandini, S. (2007). Effect of cadmium and zinc on the population growth of Brachionus havanaensis (Rotfiera: Brachionidae). Journal of Environmental Science and Health, Part A, 42:1489-1493.

Juggins, S. (2015). rioja: Analysis of Quaternary Science Data, R package version 0.9-9. $<$ http://cran.r-project.org/package=rioja $>$.

Kansas Department of Health and Environment [KDHE]: Bureau of Water. (2011). Water quality standards white paper: chlorophyll-a criteria for public water supply lakes or reservoirs. [Report].

Kaupilla, T., Moisio, T., Salonen, V. P. (2002). A diatom-based inference model for autumn epilimnetic total phosphorus concentration and its application to a presently eutrophic boreal lake. Journal of Paleolimnology, 27(2): 261-273.

Kelly, J., Champagne, P., Michel, F. (2007). Assessment of metal attenuation in a natural wetland system impacted by alkaline mine tailings, Cobalt, Ontario, Canada. Mine Water and the Environment, 26:181-190.

Kim, C. S., Stack, D. H., Rytuba, J. J. (2012). Fluvial transport and surface enrichment of arsenite in semi-arid mining regions: examples from the Mojave Desert, California. Journal of Environmental Monitoring, 14(7):1798-1813.

Knight, C.W. (1922). Geology of the mine workings of Cobalt and South Lorrain silver areas. Ontario Department of Mines. 31st Annual report, Volume 31, Part 2.

Korhola, A., Rautio, M. (2006). Cladocera and other Branchiopod Crustaceans. In Tracking environmental change using lake sediments. Vol. 4. Zoological indicators. Edited by J.P. Smol, H.J.B. Birks, and W.M. Last. Kluwer Academic Publishers, Dordrecht, the Netherlands: 5-41. 
Korosi, J. B., Ginn, B. K., Cumming, B. F., Smol, J. P. (2013). Establishing past environmental conditions and tracking long-term environmental change in the Canadian Maritime provinces using lake sediments. Environmental Reviews, 21: 15-27.

Korosi, J. B., Smol, J. P. (2012a). An illustrated guide to the identification of cladoceran subfossils from lake sediments in northeastern North America: part 1 - the Saphniidae, Leptodoridae, Bosminidae, Polyphemidae, Holopedidae, Sididae, and Macrothricidae. Journal of Paleolimnology, 48: 571-586.

Korosi JB, Smol JP (2012b). An illustrated guide to the identification of cladoceran subfossils from lake sediments in northeastern North America: part 2 - the Chydoridae. Journal of Paleolimnology, 48: 587-622.

Krammer, K., Lange-Bertalot, H., (1986). Bacillariophyceae. 1. Teil, Naviculaceae. In: Ettl, H., Gerloff, J., Heynig, H., Mollenhauer, D. (Eds.), Süßwasserflora von Mitteleuropa, Band 2/1. New York, Gustav Fischer Verlag, Stuttgart, pp. 1-876.

Krammer, K., Lange-Bertalot, H., (1988). Bacillariophyceae. 2. Teil, Bacillariaceae, Epithemiaceae, Surirellaceae. In: Ettl, H., Gerloff, J., Heynig, H., Mollenhauer, D. (Eds.), Süßwasserflora von Mitteleuropa, Band 2/2. Jena, VEB Gustav Fischer Verlag, pp. 1-596.

Krammer, K., Lange-Bertalot, H., (1991a). Bacillariophyceae. 3. Teil, Centrales, Fragilariaceae, Eunotiaceae. In: Ettl, H., Gerloff, J., Heynig, H., Mollenhauer, D. (Eds.), Süßwasserflora von Mitteleuropa, Band 2/3. Jena, Gustav Fischer Verlag, Stuttgart, pp. 1-576.

Krammer, K., Lange-Bertalot, H., (1991b). Bacillariophyceae. 4. Teil, Achnanthaceae, Kritische Ergänzungen zu Navicula (Lineolatae) und Gomphonema, Gesamtliteraturverzeichnis Teil 1-4. In: Ettl, H., Gerloff, J., Heynig, H., Mollenhauer, D. (Eds.), Süßwasserflora von Mitteleuropa, Band 2/4. Jena, Gustav Fischer Verlag, Stuttgart, pp. 1-437.

Kreidic, N., Armiento, G., Cibin, G., Cinque, G., Crovato, C., Nardia, E., Pacifico, R., Cremisini, C., Mottana, A. (2011). An integrated geochemical and mineralogical approach for the evaluation of arsenic mobility in mine soils. Journal of Soils Sediments, 11:37-52.

Kurek, J., Korosi, J. B., Jeziorski, A., Smol, J. P. (2010). Establishing reliable minimum count sizes for cladoceran subfossils sampled from lake sediments. Journal of Paleolimnology, 44:603612.

Kwong, Y., T., J., Beauchemin, S., Hossain, M., F., Gould, W., D. (2007). Transformation and mobilization of arsenic in the historic Cobalt mining camp, Ontario, Canada. Journal of Geochemical Exploration, 92(2-3):133-150.

Landner, L. (1998). Arsenic in the aquatic environment-speciation and biological effects. Report No. 2. Exemption Substances Project. Stockholm, Sweden: Printgraf.

Larsson, P. (1984). Transport of PCSs from aquatic to terrestrial environments by emerging 
chironomids. Environmental Pollution, 34:283-289.

Landrigan, P. J., Fuller, R., Acosta, N. J. R., Adeyi, O., Arnold, R., Basu, N., Baldé, A. B., Bertollini, R., Bose-O’Reilly, S., Boufford, J. I., Breysse, P. N., Chiles, T., Mahidol, C., CollSeck, A. M., Cropper, M. L. Fobil, J., Fuster, V., Greenstone, M., Haines, A., Hanrahan, D., Hunter, D., Khare, M., Krupnick, A., Lanphear, B., Lohani, B., Martin, K., Mathiasen, K. V., McTeer, M. A., Murray, C. J. L., Ndahimananjara, J. D., Perera, F., Potočnik, J., Preker, A. S., Ramesh, J., Rockström, J., Salinas, C., Samson, L. D., Sandilya, K., Sly, P. D., Smith, K. R., Steiner, A., Stewart, R. B., Suk, W. A., van Schayck, O. C. P., Yadama, G. N., Yumkella, K., Zhong, M. (2017). The Lancet commission on pollution and health. The Lancet, 391(10119):462-512.

Lemay. D. (2015). Geochemistry of lakes across ecozones in the Northwest Territories and implications for the distribution of arsenic in the Yellowknife region. Part 1: sediments. Geological Survey of Canada. Open File: 7908.

Leppänen, J. J. (2018). An overview of Cladoceran studies conducted in mine water impacted lakes. International Aquatic Research, 1-15.

Leung, A. (2009). Heavy metals in sediments, water and fish from the lakes of Cobalt, Ontario. [Technical Report].

Liao, C., Jau, S., Chen, W., Lin, C., Jou, L., Liu, C., Liao, V. H., Chang, F. (2008). Acute toxicity and bioaccumulation of arsenic in freshwater clam Corbicula fluminea. Environmental Toxicology, 23(6).

Lima, A. R., Curtis, C., Hammermeister, D. E., Markee, T. P., Northcott, C. E., Brooke, L. T. (1984). Acute and chronic toxicities of arsenic(III) to fathead minnows, flagfish, daphnids, and an amphipod. Archives of Environmental Contamination and Toxicology, 13:595-601.

Ljung, K., Selinus, O., Otabbong, E., Berglund, M. (2002). Metal and arsenic distribution in soil particle sizes relevant to soil ingestion by children. Applied Geochemistry, 21:1613-1624.

Luís, A. T., Teixeira, P., Almeida, S. F. P., Matos, J. X., Ferreira da Silva, E. (2011). Environmental impact of mining activities in the Lousal area (Portugal): chemical and diatom characterization of metal-contaminated stream sediments and surface water of Corona stream. Science of the Total Environment, 409:4312-4325.

Martinez, E. A., Moore, B. C., Schaumloffel, J., Dasgupta, N. (2002). The potential association between menta deformaties and trace elements in Chironomidae (Diptera) taken from a heavy metal contaminated river. Environmental Contamination and Toxicology, (42):286-921.

Martinez, E. A., Wold, L., Moore, B. C., Schaumloffel, J., Dasgupta, N. (2006). Morphologic and growth responses in Chironomus tentans to arsenic exposure. Environmental Contamination and Toxicology, 51:529-536). 
McGeer, J., Henningsen, G., Lanno, R., Fisher, N., Sappington, K., Drexler, J. (2004). Issue paper on the bioavailability and bioaccumulation of metals. U.S. Environmental Protection Agency [US EPA].

McIlwaine, W.H. (1970). Geology of the South Lorrain Township, District Timiskaming, Ontario Geological Survey, Geological Report R83: 117.

Meharg, A. A., Wright, J., Dyke, H., Osborn, D. (1998). Polycyclic aromatic hydrocarbon (PAH) dispersion and deposition to vegetation and soil following a large scale chemical fire.

Environmental Pollution, 99(1):29-36.

Meregali, G., Pluymers, L., Ollevier, F. (2001). Induction of mouthpart deformities in Chironomus riparius larvae exposed to 4-n-nonylphenol. Environmental Pollution, (111):241246.

Michel, F. A., Henein, K. (2007). Natural re-vegetation of arsenic-bearing alkaline tailings at Cobalt, Ontario. [Technical Report]. Presented at Sudbury 2007. Laurentian University. Sudbury, Ontario, Canada.

Miller, W. G. (1903). Cobalt-nickel arsenides and silver. Ontario Bureau of Mines Annual Report for 1903. Vol. 13, Pt. 1. pp. 96-103.

Ministry of the Environment and Energy [MEE]. (1994). Water management: Policies, guidelines, provincial water quality objectives (PWQO). Prepared by Ministry of the Environment and Energy.

Moreira, R. A., Mansano, A. D., Rocha, O. (2015). The toxicity of carbofuran to the freshwater rotifer, Philodina roseola. Ecotoxicology, 24:604-615.

Moos, M. T., Laird, K. R., Cumming, B. F. (2005). Diatom assemblages and water depth in Lake 239 (Experimental Lakes Area, Ontario): implications for paleoclimatic studies. Journal of Paleolimnology, 34:217-227.

Mudd, G. M. (2007). Global trends in gold mining: Towards quantifying environmental and resource sustainability? Resources Policy, 32, 42-56.

Nasser, N. A., Patterson, R. T., Roe, H. M., Galloway, J. M., Falck, H., Palmer, M. J., Spence, C., Sanei, H., Macumber, A. L., Neville, L. A. (2016). Lacustrine arcellinina (testate amoebae) as bioindicators of arsenic contamination. Environmental Microbiology, 72:130-149.

The National Academies Press [NAS]. (1977). Arsenic. National Academy of Sciences. Washington, D.C.

National Academy of Sciences. (1977). Arsenic. Philadelphia, Pennsylvania: Committee on medical and biological effects of environmental pollution. Division of Biological Sciences. Assembly of Life Sciences, National Research Council. 
National Research Council of Canada [NRCC]. (1978). Effects of arsenic in the Canadian environment. National Research Council of Canada. Report No. NRCC 15391.

Naumann, B., Eberius, M., Appenroth, K. (2007). Growth rate based dose-response relationships and EC-values of ten heavy metals using the duckweed growth inhibition test (ISO 20079) with Lemna minor L. clone St. Journal of Plant Physiology, 164(12):1656-1664.

Nevalainen, L., Rantala, M. V., Rautio, M., Luoto, T. P. (2018). Spatio-temporal cladoceran (Branchipoda) responses to climate change and UV radiation in subarctic ecotonal lakes. Journal of Biogeography, 45:1954-1965.

Nikolaidis, N.P., Dobbsb, G.M., Chenc, J., Lackovicc, J.A. (2004). Arsenic mobility in contaminated lake sediments. Journal of Environmental Pollution, 129(3), 479-487.

Nilssen, J. P., 1978. Selective vertebrate and invertebrate predation-some palaeolimnological implications. Polish Archives of Hydrobiology, 25:307-320.

Oksanen, J. F., Blanchet, G., Friendly, M., Kindt, R., Legendre, P., McGlinn, D., Minchin, P. R., O’Hara, R. B., Simpson, G. L., Solymos, P., Stevens, M. H. H., Szoecs, E., Wagner, H. (2017). vegan: Community Ecology Package. R package version 2.4-2. $<$ https://CRAN.Rproject.org/package $=$ vegan $>$.

Orelamnd, R. S., Stolz, J. F. (2003). The ecology of arsenic. Science, 300: 939-944.

Paktunc, D. (2013). Mobilization of arsenic from mine tailings through reductive dissolution of goethite influenced by organic cover. Applied Geochemistry, 36:49-56.

Parks, W. A. (104). The geology of a district from Lake Timiskaming northward. Geological Survey of Canada, Annual Report for 1904. pp. 198-212.

Parviainen, A., Isosaari, P., Loukola-Ruskeeniemi, K., Nieto, J. M., Gervilla, F. (2012). Occurrence and mobility of As in the Ylöjärvi $\mathrm{Cu}-\mathrm{W}$-As mine tailings. Journal of Geochemical Exploration, 114:36-45.

Passino, D. R. M., Novak, A. J. (1984). Toxicity of arsenate and DDT to the cladoceran Bosmina longirostris. Bulletin of Environmental Contamination and Toxicology, 33 325-329.

Patterson, R. T., Barker, T., Burbridge, S. M. (1996). Arcellaceans (Thecamoebians) as proxies of arsenic and mercury contamination in northeastern Ontario lakes. Journal of Foraminiferal Research, 26:172-183.

Patterson, R. T., Kumar, A. (2000). Use of arcellacea to gauge levels of pollution and remediation of industrially polluted lakes, in Martin, R.E. (ed) Environmental Micropaleontology, vol. 15 of Topics in Geobiology, Kluwer Academic/ Plenum Publication, p. 257-278.

Percival, J. B., Kwong, Y. T. J., Dumaresq, C. G., Michel, F. A. (2004). Transport and 
attenuation of arsenic, cobalt, and nickel in an alkaline environment (Cobalt, Ontario). Geological Survey of Canada. Open File 1680.

Petruk, W. (1971). General characteristics of the deposits. In: Berry, L.G. (Ed.), The SilverArsenide Deposits of the Cobalt-Gowganda Region, Ontario. Canadian Mineralogist, 11:76107.

Pienitz, R., Smol, J. P. (1993). Diatom assemblages and their relationship to environmental variables in lakes from the boreal forest-tundra ecotone near Yellowknife, Northwest Territories, Canada. Hydrobiologia, 269/270, 391-404.

Planas, D., Healey, F.P. (1978). Effects of arsenate on growth and phosphorus metabolism of phytoplankton. Journal of Phycology, 14:337-341.

Quinlan, R., Smol, J.P. (2001). Setting minimum head capsule abundance and taxa deletion criteria in chironomid-based inference models. Journal of Paleolimnology. 26(3): 327-342.

R Core Team (2016). R: A language and environment for statistical computing. R Foundation for Statistical Computing, Vienna, Austria. <https://www.R-project.org/>.

Rahman, M. A., Hogan, B. Duncan, E., Doyle, C., Krassoi, R., Rahman, M. M., Naidu, R., Lim, R. P., Maher, W., Hassler, C. (2014). Toxicity of arsenic species to three freshwater organisms and biotransformation of inorganic arsenic by freshwater phytoplankton (Chlorella sp. CE-35). Ecotoxicology and Environmental Safety, 106:126-135.

Reinhardt, E. G., Dalby, A., Kumar, A., Patterson, R. T. (1998). Arcellaceans as pollution indicators in mine tailing contaminated lakes near Cobalt, Ontario, Canada. Micropaleontology, 44:131-148.

Reynoldson, T. B. (1987). Interactions between sediments contaminants and benthic organisms. Hydrobiologia, 315:159-169.

Rico-Martínez, R., Arzate-Cárdenas, M. A., Robles-Vargas, D., Pérez-Legaspi, I. A., Jesús, A.F., Santos-Medrano, G. E. (2016). Rotifers as models in toxicity screening of chemicals and environmental samples. Invertebrates. Ed.: Larramedy, M. L., Soloneski, S. IntechOpen.

Rizopoulos, D. (2006). 1tm: An R package for Latent Variable Modelling and Item Response Theory Analyses. Journal of Statistical Software, 17 (5), 1-25.

$<\underline{\text { http://www.jstatsoft.org/v17/i05/>. }}$

Sanders, J. G. (1986). Direct and indirect effects of arsenic on the survival and fecundity of estuarine zooplankton. Canadian Journal of Fisheries and Aquatic Sciences, 43:694-699.

Schuh, C. E., Jamieson, H. E., Palmer, M. J., Martin, A. J., Blais, J. M. (2019). Controls governing the spatial distribution of sediment arsenic concentrations and sold-phase speciation in a lake impacted by legacy mining pollution. Science of the Total Environment, 654:563-575.

Semlali, R. M., van Oort, F., Denaix, L. M. L. (2001). Estimating distributions of endogenous 
and exogenous $\mathrm{Pb}$ in soils by using $\mathrm{Pb}$ isotopic ratios. Environmental Science and Technology, $35: 4180-4188$.

Shaw, J. R., Glaholt, S. P., Greenberg, N. S., Sierra-Alvarez, R., Folt, C. L. (2009). Acute toxicity of arsenic to Daphnia pulex: Influence of organic functional groups and oxidation state. Environmental Toxicology and Chemistry, 26(7).

Smith, E., Naidu, R., Alston, A. M. (1999). Chemistry of arsenic in soils: I. Soprtion of arsenate and arsenite by four Australian soils. Journal of Environmental Quality, 28:1719-1726.

Smith, P. (1986). Harvest from the rock: A history of mining in Ontario. MacMillan of Canada.

Smol, J. P. (2008). Pollution of lakes and rivers: A paleoenvironmental perspective. $2^{\text {nd }}$ ed. Wiley-Blackwell Publishing, Oxford, UK.

Snell, T. W., Janssen, C. R. (1995). Rotifers in ecotoxicology: a review. Hydrobiologia, 313/314:231-247.

Spehar, R.L., Fiant, J.T. (1986). Acute and chronic effects of water quality on mixtures of three aquatic species. Environmental Toxicology and Chemistry, 5:917-931.

Spehar, R. L., J. T. Fiandt, R. L. Anderson, DeFoe, D. L. (1980). Comparative toxicity of arsenic compounds and their accumulation in invertebrates and fish. Archives of Environmental Contamination and Toxicology, 9:53-63.

Sprague, D. D. (2017). Lake sediment geochemistry in northeastern Ontario; the geologic controls on natural background variation and investigating lakes contaminated with arsenic-rich mine tailings in Cobalt, ON. [Master's thesis]. Carleton University, Canada.

Sprague, D. D., Michel, F. A., Vermaire, J. C. (2016). The effects of migration on ca. 100-yearold arsenic-rich tailings in Cobalt, Ontario, Canada. Environmental Earth Sciences, 75(405).

Sprague, D. D., Vermaire, J. C. (2018). The landscape-scale relationship between lake sediment geochemistry and catchement bedrock composition from the Temagami and Gowganda areas of Northeastern Ontario, Canada. Environmental Earth Sciences, 77: 463.

Stewart, E. M., Hargan, K. E., Sivarajah, B., Kimpe, L. E., Blais, J. M., Smol, J. P. (2018). A paleoenvironmental study tracking eutrophication, mining pollution, and climate change in Niven Lake, the first sewage lagoon in Yellowknife (Northwest Territories). Arctic, 71(2): 201217.

Swansburg, E. O., Fairchild, W. L., Fryer, B. J., Ciborowski, J. J. H. (2009). Mouthpasrt deformities and community composition of chironomidae (diptera) larvae downstream of metal mines in New Brunswick, Canada. Journal of Environmental Toxicology and Chemistry, 21(12).

Sweetman, J. N., Smol, J. P. (2006). Patterns in the distribution of cladocerans (Crustacea: Branciopoda) in lakes across a north-south transect in Alaska, USA. Hydrobiolgia, 553:227-91. 
Szeroczyńska, K., Sarmaja-Korjonen, K. (2007). Atlas of subfossil Cladocera from central and northern Europe. Swiecie: Friends of the Lower Vistula Society.

Taylor, D., B. G. Maddock, Mance, G. (1985). The acute toxicity of nine 'grey list' metals (arsenic, boron, chromium, copper, lead, nickel, tin, vanadium and zinc) to two marine fish species: dab (Limanda limanda) and grey mullet (Chelon labrosus). Aquatic Toxicology, 7:135144.

Tenkouano, G.-T., Cumming, B. F., Jamieson, H. E. (2019). Geochemical and ecological changes within Moira Lake (Ontario, Canada): a legacy of industrial contamination and remediation. Environmental Pollution, 247: 980-988.

Ter Braak, C. J. F., Prentice, I. C. (1988). A theory of gradient analysis. Advances in Ecological Research, 18:271-317.

Thienpont, J. R., Korosi, J. B., Hargan, K. E., Williams, T., Eickmeyer, D. C., Kimpe, L. E., Palmer, M. J., Smol, J. P. (2016). Multi-trophic level response to extreme metal contamination from gold mining in a subarctic lake. Proceedings of the Royal Society B, 283.

Thomson, R. (1964). Cobalt Silver Area, Northern, Southeastern and Southwestern Map Sheets, Ontario Geological Survey, Maps M2050, M2051, M2052, scale 1:12,000.

Thursby, G. B., Steele, R. L. (1984). Toxicity of arsenite and arsenate to the marine macroalgae Champia parvula (Rhodophyta). Environmental Toxicology and Chemistry, 3:391-397.

Tolonen, A., 1998. Size-specific food selecyion and growth in benthic whitefish, Coregonus lavaretus (L.), in a subarctic lake. Boreal Environmental Research, 2: 387-399.

Turpeinen, R., Virta, M., Häggblom, M. M. (2002). Analysis of arsenic bioavaility in contaminated soils. Environmental Toxicology and Chemistry, 22(1): 1-6.

U.S. EPA (1980). Water-related environmental fate of 129 priority pollutants. Vol. 1. Introduction, technical background, metals and inorganics, pesticides and PCBs. Office of Water Planning and Standards, U.S. Environmental Protection Agency, Washington, D.C. EPA440/4-79-029a.

Uutala, A. J., Yan, N. D., Dixit, A. S., Dixit, S. S., Smol, J. P. (1994). Paleolimnological assessment of damage to fish communities in three acidic, Canadian Shield lakes. Fisheries Research, 19: 157-177.

Verb, R. H., Vis, M. L. (2000). Comparison of benthic diatom assemblages from streams draining abandoned and reclaimed coal mines and nonimpacted sites. Journal of the North American Benthological Society, 19:274-288.

Vocke, R.W., K.L. Sears, J.J. O’Toole, and R.B. Wildman. (1980). Growth responses of selected freshwater algae to trace elements and scrubber ash slurry generated by coal-fired power plants. Water Research, 14:141-150. 
Walker, I. R. (2001). Midges: Chironomidae and related Diptera. In: Smol JP, Birks HJB, Last WM (eds) Tracking J Paleolimnol (2012) 47:561-581 environmental change using lake sediments, vol 4: zoological indicators. Kluwer, Dordrecht, pp 43-66.

Wang, S., \& Mulligan, C. N. (2006). Occurrence of arsenic contamination in Canada: Sources, behavior and distribution. Science of the Total Environment, 366: 701-721.

Warwick, W. F. (1990). The use of morphological deformities in chironomid larvae for biological effects monitoring. National Hydrology Research Institute, 43. Ottawa, Ontario, Canada.

Weckström, J., Korhola, A., Blom, T. (1997). Diatoms as quantitative indicators of pH and water temperature in subarctic Fennoscandian lakes. Hydrobiologia, 347:171-184.

Wei, T., Simko, V. (2016). corrplot: Visualization of a Correlation Matrix. R package version 0.77. $<$ https://CRAN.R-project.org/package=corrplot $>$.

Wentsel, R., McIntosh, A., McCafferty, W. P., Atchison, G., Anderson, V. (1977). Avoidance response of midge larvae (Chrisonomus tentans) to sediments containing heavy metals. Hydrobiologia, 55(2):171-175.

Williams, K. A., Green, D. W. J., Pascoe, D., Gower, D. E. (1986). The acute toxicity of cadmium to different larval stages of Chironomus riparius (Diptera: Chironomidae) and its ecological significance for pollution regulation. Oecologia, 70:362-366.

Wilson, M. A. (2003). The effects of discharge of effluent from small-diameter mineral exploration drilling to Arctic lakes. [Master's thesis]. University of Manitoba, Canada.

Wilson, S. E., Cumming, B. F., Smol, J. P. (1994). Diatom-salinity relationships in 111 lakes from the Interior Plateau of British Columbia, Canada: the development of diatom-based models for paleosalinity reconstructions. Journal of Paleolimnology, 12(3):197-221.

Wright, D. A., Welbourn, P. (2002). Environmental toxicology. New York, NY: Cambridge University Press.

Yao, Q., Wang, X., Jian, H., Chen, H., Yu, Z. (2015). Characterization of the particle size fraction associated with heavy metals in suspended sediments of the Yellow River. International Journal of Environmental Research and Public Health, 12(6):6725-6744. 


\section{APPENDICES}

\section{A. WATER CHEMISTRY DATA}

Table 6-1: Surface water chemistry and environmental variable data from the 24-lake gradient from the Cobalt, Ontario region.

\begin{tabular}{|c|c|c|c|c|c|c|c|c|c|c|c|c|c|c|c|c|c|c|c|c|c|c|c|c|}
\hline $\begin{array}{c}\text { Environmental } \\
\text { Variables }\end{array}$ & 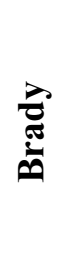 & $\underset{\pi}{\pi}$ & $\frac{\grave{J}}{\stackrel{\Xi}{\circlearrowright}}$ & 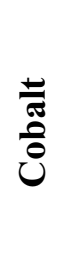 & 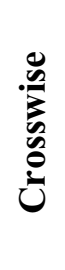 & 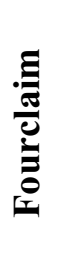 & 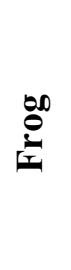 & 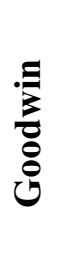 & $\underset{\circlearrowright}{0}$ & 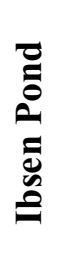 & $\underline{\square}$ & 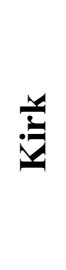 & 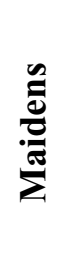 & $\begin{array}{l}\Xi \\
\sum \\
\sum \\
\sum \\
\sum\end{array}$ & Z & $\stackrel{\bar{e}}{\ddot{Z}}$ & 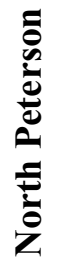 & 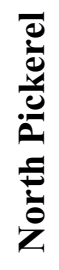 & $\frac{3}{0}$ & $\stackrel{0}{\mathscr{E}}$ & $\stackrel{\grave{\partial}}{\grave{n}}$ & 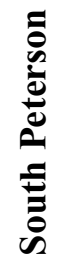 & 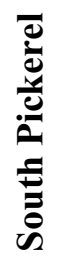 & $\stackrel{0}{\circ}$ \\
\hline Aluminum $(\mu \mathrm{g} / \mathrm{L})$ & 20 & 20 & 10 & 70 & 40 & 20 & 40 & 20 & 30 & 70 & 10 & 30 & 20 & 40 & 30 & 60 & 10 & 30 & 70 & 70 & 50 & 10 & 40 & 20 \\
\hline Antimony $(\mu \mathrm{g} / \mathrm{L})$ & 3.7 & 6.9 & 0.2 & 12.9 & 1 & 6.3 & 0.2 & 0.1 & 0.2 & 0.7 & 12.1 & 1 & 0.4 & 0.1 & 0.4 & 0.1 & 5 & 0.2 & 0.1 & 0.3 & 0.1 & 4.6 & 0.2 & 0.4 \\
\hline Arsenic $(\mu \mathrm{g} / \mathrm{L})$ & 140 & 972 & 2 & 495 & 82.4 & 542 & 0.7 & 1.4 & 2.9 & 142 & 348 & 34 & 23.6 & 0.9 & 36.8 & 0.7 & 312 & 5 & 0.7 & 0.4 & 7.3 & 297 & 3.3 & 635 \\
\hline Bicarbonate (mg/L) & 100 & 76 & 68 & 129 & 66 & 42 & 58 & 72 & 59 & 70 & 127 & 66 & 28 & 86 & 41 & 60 & 107 & 74 & 6.0 & 43 & 60 & 103 & 70 & 28 \\
\hline Cadmium $(\mu \mathrm{g} / \mathrm{L})$ & 0 & 0 & 0 & 0.4 & 0 & 0 & 0 & 0 & 0 & 0.4 & 0 & 0 & 0 & 0 & 0 & 0.1 & 0 & 0 & 0 & 0 & 0 & 0 & 0 & 0 \\
\hline Calcium (mg/L) & 35.2 & 21 & 24.8 & 49 & 20.7 & 14.5 & 19.1 & 23 & 20.1 & 24.9 & 47.8 & 21.1 & 11.5 & 26.7 & 13.9 & 19.8 & 32.2 & 26.3 & 3.5 & 18.7 & 19.3 & 31.4 & 24.4 & 9.2 \\
\hline Chloride (mg/L) & 0.6 & 0.5 & 30.9 & 22.1 & 0.5 & 0.5 & 0.6 & 0.5 & 17.6 & 0.5 & 1.1 & 0.5 & 10.6 & 0.5 & 0.5 & 0.5 & 0.8 & 0.6 & 0.5 & 0.5 & 0.5 & 0.8 & 0.6 & 0.5 \\
\hline Cobalt $(\mu \mathrm{g} / \mathrm{L})$ & 1.1 & 1.7 & 0.1 & 2.7 & 0.3 & 0.8 & 0.1 & 0.1 & 0.1 & 10.5 & 624 & 0.2 & 0.1 & 0.1 & 1.8 & 0.2 & 0.9 & 0.1 & 0.1 & 0.1 & 0.3 & 1 & 0.1 & 0.1 \\
\hline Conductivity (S/m) & 220 & 165 & 253 & 366 & 141 & 95 & 129 & 153 & 190 & 161 & 334 & 141 & 105 & 181 & 97.5 & 135 & 227 & 161 & 27 & 116 & 132 & 220 & 152 & 68.1 \\
\hline Copper $(\mu \mathrm{g} / \mathrm{L})$ & 0.1 & 1.6 & 0.1 & 2.3 & 1.2 & 0.1 & 0.2 & 0.1 & 0.1 & 1.5 & 0.9 & 0.7 & 0.6 & 0.1 & 0.3 & 1.5 & 2.1 & 0.5 & 0.1 & 0.1 & 0.7 & 1.1 & 0.9 & 0.1 \\
\hline Iron $(\mu \mathrm{g} / \mathrm{L})$ & 51 & 45 & 12 & 188 & 31 & 38 & 35 & 9 & 61 & 251 & 5 & 36 & 5 & 67 & 21 & 5 & 22 & 14 & 37 & 174 & 52 & 22 & 15 & 5 \\
\hline Lead $(\mu \mathrm{g} / \mathrm{L})$ & 0.1 & 0.4 & 0 & 0.5 & 0.2 & 0 & 0 & 0 & 0.1 & 0.8 & 0 & 0.1 & 0 & 0.1 & 0 & 1.2 & 0 & 0.2 & 0.8 & 0 & 0.1 & 0 & 0.3 & 0 \\
\hline Magnesium (mg/L) & 6.9 & 6.9 & 3.9 & 9.2 & 5.1 & 2.1 & 4.9 & 5.5 & 4.4 & 6.2 & 12 & 4.9 & 4.3 & 6.6 & 3.8 & 5 & 8.1 & 3.8 & 0.9 & 4.2 & 5.3 & 7.7 & 3.6 & 1.9 \\
\hline Nickel $(\mu \mathrm{g} / \mathrm{L})$ & 2.1 & 5.3 & 0.5 & 10.2 & 2.5 & 3.6 & 0.6 & 1 & 0.7 & 7.8 & 120 & 1.3 & 1.3 & 0.7 & 2.9 & 7.4 & 7.6 & 0.9 & 0.5 & 0.7 & 1.5 & 5.2 & 0.8 & 0.8 \\
\hline $\mathrm{pH}$ & 8.7 & 8.9 & 8.1 & 8.3 & 8.1 & 8.2 & 6.9 & 8.3 & 8.5 & 8.8 & 9 & 8.1 & 7.8 & 7.2 & 8 & 9.2 & 8 & 8.7 & 7.2 & 8.1 & 8.8 & 8.3 & 8.5 & 7.7 \\
\hline Potassium (mg/L) & 0.6 & 0.9 & 0.4 & 1 & 0.3 & 0.7 & 0.2 & 0.2 & 0.4 & 0.2 & 1.2 & 0.3 & 0.3 & 0.3 & 0.2 & 0.3 & 0.8 & 0.2 & 0.2 & 0.3 & 0.3 & 0.8 & 0.2 & 0.3 \\
\hline
\end{tabular}


Silver $(\mu \mathrm{g} / \mathrm{L})$

Sodium $(\mathrm{mg} / \mathrm{L})$

Sulphate $(\mathrm{mg} / \mathrm{L})$

Total Dissolved Solids (mg/L)

Uranium $(\mu \mathrm{g} / \mathrm{L})$

Water Depth (m)

Zinc $(\mu \mathrm{g} / \mathrm{L})$

Table 6-2: Surface water chemistry and environmental variable data from the 10-lake gradient from the Cobalt, Ontario region.

\begin{tabular}{|c|c|c|c|c|c|c|c|c|c|c|}
\hline $\begin{array}{c}\text { Environmental } \\
\text { Variables }\end{array}$ & 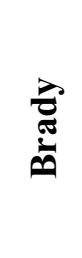 & $\underset{\pi}{\pi}$ & $\frac{\grave{\Xi}}{\circlearrowright}$ & $\begin{array}{l}\frac{\hbar}{\pi} \\
\frac{0}{0} \\
ن\end{array}$ & $\frac{\mathscr{y}}{0}$ & 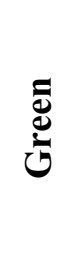 & $\underline{\square}$ & 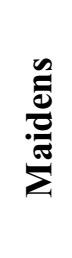 & 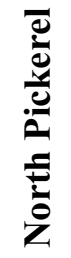 & $\frac{3}{8}$ \\
\hline Aluminum $(\mu \mathrm{g} / \mathrm{L})$ & 16.7 & 26.7 & 10 & 16.7 & 50 & 20 & 20 & 20 & 30 & 60 \\
\hline Arsenic $(\mu \mathrm{g} / \mathrm{L})$ & 142.3 & 1113.3 & 3.2 & 505 & 89.6 & 3.8 & 328.7 & 21.6 & 4.9 & 0.9 \\
\hline Boron $(\mu \mathrm{g} / \mathrm{L})$ & 11 & 8 & 5 & 12 & 6 & 5 & 16.3 & 5 & 5 & 5 \\
\hline Cadmium $(\mu \mathrm{g} / \mathrm{L})$ & 0.2 & 0 & 0.1 & 0 & 0.1 & 0 & 0.1 & 0 & 0 & 0 \\
\hline Calcium $(\mu \mathrm{g} / \mathrm{L})$ & 28.3 & 23.9 & 25.1 & 41.1 & 19.7 & 18.7 & 49.1 & 12.4 & 25.9 & 3.1 \\
\hline $\begin{array}{l}\text { Chlorophyll-a Concentration } \\
(\mathrm{mg} / \mathrm{L})\end{array}$ & 4.4 & 0.6 & 3.9 & 1.2 & 1.2 & 1.5 & 2.4 & 1.2 & 2.4 & 2.7 \\
\hline Copper $(\mu \mathrm{g} / \mathrm{L})$ & 2 & 3 & 1.2 & 2.3 & 3.1 & 0.9 & 1.9 & 1.4 & 1.9 & 0.6 \\
\hline Hardness $(\mu \mathrm{g} / \mathrm{L})$ & 98 & 88 & 79.3 & 136.3 & 68.7 & 64.3 & 173.3 & 51.7 & 80.3 & 11 \\
\hline Iron $(\mu \mathrm{g} / \mathrm{L})$ & 19.3 & 75.3 & 10 & 19.7 & 42.7 & 63.3 & 5 & 12.3 & 19.7 & 45 \\
\hline Lead $(\mu \mathrm{g} / \mathrm{L})$ & 1.9 & 0.6 & 0.6 & 0.1 & 1 & 0.1 & 0.1 & 0 & 0.9 & 0.1 \\
\hline Magnesium $(\mu \mathrm{g} / \mathrm{L})$ & 6.7 & 6.8 & 4 & 8.2 & 4.7 & 4.2 & 12.3 & 5 & 3.8 & 0.8 \\
\hline
\end{tabular}




\begin{tabular}{|c|c|c|c|c|c|c|c|c|c|c|}
\hline Molybdenum $(\mu \mathrm{g} / \mathrm{L})$ & 0.6 & 3.8 & 0.1 & 3.6 & 0.4 & 0.1 & 2.4 & 0.1 & 0.2 & 0.1 \\
\hline Nickel $(\mu \mathrm{g} / \mathrm{L})$ & 1.9 & 5.9 & 0.8 & 8.5 & 2.7 & 0.9 & 166 & 1.2 & 1.4 & 0.2 \\
\hline PAR (mmol) & 191.7 & 2347 & 121.7 & 468.4 & 1147 & 1174.3 & 167.7 & 412.8 & 228.2 & 205.4 \\
\hline $\mathrm{pH}$ & 8.5 & 8.9 & 8.4 & 8.5 & 8.8 & 8.1 & 8.9 & 8.3 & 9 & 8.7 \\
\hline Silver $(\mu \mathrm{g} / \mathrm{L})$ & 0 & 0.1 & 0 & 0 & 0 & 0 & 0 & 0 & 0 & 0 \\
\hline Uranium $(\mu \mathrm{g} / \mathrm{L})$ & 0.1 & 0.2 & 0.1 & 0.4 & 0.1 & 0.1 & 0.5 & 0.1 & 0.1 & 0.1 \\
\hline Water Depth (m) & 8.5 & 1.6 & 19.8 & 6.1 & 7.3 & 4.8 & 26.2 & 7.6 & 2.6 & 8.7 \\
\hline $\operatorname{Zinc}(\mu \mathrm{g} / \mathrm{L})$ & 5.3 & 6.7 & 5 & 5 & 5 & 5 & 28.3 & 5 & 5 & 5 \\
\hline
\end{tabular}

Table 6-3: Correlation matrix for the raw 24-lake surface water data sampled in 2015 . All variables found to have correlation of $\geq 0.70$ with one another were removed from further statistical analysis.

\begin{tabular}{|c|c|c|c|c|c|c|c|c|c|c|c|c|c|c|c|c|c|c|c|c|c|c|c|c|}
\hline $\begin{array}{c}\text { Environmental } \\
\text { Variables }\end{array}$ & 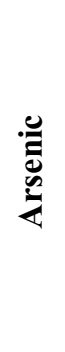 & 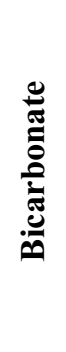 & 导 & 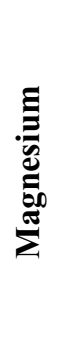 & 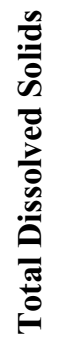 & 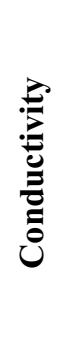 & 풀 & 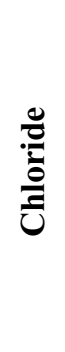 & 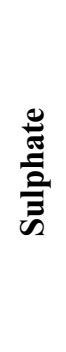 & 馬 & 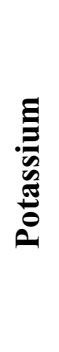 & 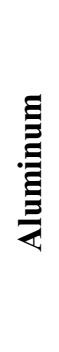 & 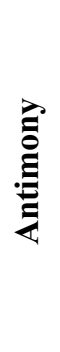 & 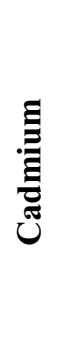 & $\underset{\Xi}{\stackrel{\Xi}{\Xi}}$ & 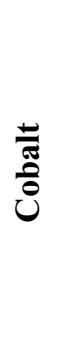 & $\frac{\dot{\bar{d}}}{\dot{0}}$ & $\stackrel{0}{0}$ & త్ర్త & $\begin{array}{l}\bar{d} \\
\frac{d}{e} \\
\frac{0}{2}\end{array}$ & $\stackrel{\grave{D}}{\bar{D}}$ & 咅 & $\stackrel{\circlearrowright}{\text { : }}$ & 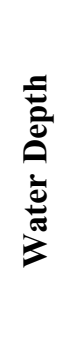 \\
\hline Arsenic & 1.0 & 0.24 & 0.18 & 0.26 & 0.22 & 0.20 & 0.20 & -0.01 & 0.46 & 0.32 & 0.63 & -0.32 & 0.72 & 0.13 & 0.20 & 0.42 & 0.39 & 0.03 & -0.01 & 0.46 & 0.27 & 0.25 & 0.06 & -0.03 \\
\hline Bicarbonate & 0.24 & 1.0 & 0.97 & 0.90 & 0.92 & 0.92 & 0.41 & 0.41 & 0.60 & 0.34 & 0.58 & -0.33 & 0.61 & 0.41 & 0.28 & 0.58 & 0.56 & 0.13 & -0.01 & 0.63 & -0.02 & 0.56 & 0.09 & -0.03 \\
\hline Calcium & 0.18 & 0.97 & 1.0 & 0.89 & 0.96 & 0.95 & 0.42 & 0.48 & 0.67 & 0.40 & 0.55 & -0.25 & 0.60 & 0.51 & 0.36 & 0.62 & 0.50 & 0.15 & 0.01 & 0.63 & -0.10 & 0.58 & 0.22 & 0.05 \\
\hline Magnesium & 0.26 & 0.90 & 0.89 & 1.0 & 0.85 & 0.84 & 0.39 & 0.38 & 0.58 & 0.43 & 0.58 & -0.30 & 0.61 & 0.51 & 0.28 & 0.73 & 0.57 & 0.10 & -0.04 & 0.77 & 0.11 & 0.65 & 0.28 & 0.02 \\
\hline $\begin{array}{c}\text { Total Dissolved } \\
\text { Solids }\end{array}$ & 0.22 & 0.92 & 0.96 & 0.85 & 1.0 & 1.0 & 0.38 & 0.65 & 0.69 & 0.53 & 0.62 & -0.35 & 0.58 & 0.48 & 0.35 & 0.59 & 0.48 & 0.10 & -0.03 & 0.59 & -0.10 & 0.54 & 0.16 & 0.13 \\
\hline $\mathbf{p H}$ & 0.20 & 0.41 & 0.42 & 0.39 & 0.38 & 0.38 & 1.0 & 0.07 & 0.28 & 0.05 & 0.31 & -0.08 & 0.30 & 0.46 & 0.18 & 0.46 & 0.42 & -0.05 & 0.32 & 0.55 & 0.46 & 0.48 & 0.19 & -0.28 \\
\hline Chloride & -0.01 & 0.41 & 0.48 & 0.38 & 0.65 & 0.66 & 0.07 & 1.0 & 0.53 & 0.66 & 0.45 & -0.42 & 0.29 & 0.16 & 0.21 & 0.17 & 0.19 & -0.15 & -0.22 & 0.18 & -0.32 & 0.11 & -0.10 & 0.32 \\
\hline Sulphate & 0.46 & 0.60 & 0.67 & 0.58 & 0.69 & 0.67 & 0.28 & 0.53 & 1.0 & 0.53 & 0.56 & -0.54 & 0.73 & 0.20 & 0.17 & 0.68 & 0.24 & -0.12 & -0.24 & 0.57 & -0.23 & 0.22 & 0.23 & 0.19 \\
\hline Sodium & 0.32 & 0.34 & 0.40 & 0.43 & 0.53 & 0.54 & 0.05 & 0.66 & 0.53 & 1.0 & 0.54 & -0.27 & 0.47 & 0.16 & 0.43 & 0.37 & 0.20 & 0.35 & -0.19 & 0.26 & -0.03 & 0.14 & 0.19 & 0.22 \\
\hline
\end{tabular}




\begin{tabular}{|c|c|c|c|c|c|c|c|c|c|c|c|c|c|c|c|c|c|c|c|c|c|c|c|c|}
\hline Potassium & 0.63 & 0.58 & 0.55 & 0.58 & 0.62 & 0.62 & 0.31 & 0.45 & 0.56 & 0.54 & 1.0 & -0.51 & 0.79 & 0.16 & 0.04 & 0.47 & 0.38 & 0.05 & -0.20 & 0.57 & 0.08 & 0.31 & 0.05 & 0.01 \\
\hline Aluminum & -0.32 & -0.33 & -0.25 & -0.30 & -0.35 & -0.33 & -0.08 & -0.42 & -0.54 & -0.27 & -0.51 & 1.0 & -0.43 & 0.29 & 0.35 & -0.25 & 0.06 & 0.54 & 0.68 & -0.25 & 0.21 & 0.13 & 0.34 & -0.03 \\
\hline Antimony & 0.72 & 0.61 & 0.60 & 0.61 & 0.59 & 0.57 & 0.30 & 0.29 & 0.73 & 0.47 & 0.79 & -0.43 & 1.0 & 0.27 & 0.21 & 0.71 & 0.52 & 0.15 & -0.14 & 0.73 & -0.05 & 0.42 & 0.20 & 0.16 \\
\hline Chromium & 0.20 & 0.28 & 0.36 & 0.28 & 0.35 & 0.36 & 0.18 & 0.21 & 0.17 & 0.43 & 0.04 & 0.35 & 0.21 & 0.64 & 1.0 & 0.36 & 0.45 & 0.45 & 0.41 & 0.33 & 0.11 & 0.47 & 0.37 & -0.02 \\
\hline Cobalt & 0.42 & 0.58 & 0.63 & 0.73 & 0.59 & 0.56 & 0.46 & 0.17 & 0.68 & 0.37 & 0.47 & -0.25 & 0.71 & 0.61 & 0.36 & 1.0 & 0.44 & 0.06 & 0.02 & 0.91 & 0.13 & 0.60 & 0.54 & 0.09 \\
\hline Copper & 0.39 & 0.56 & 0.50 & 0.57 & 0.48 & 0.48 & 0.42 & 0.19 & 0.24 & 0.20 & 0.38 & 0.06 & 0.52 & 0.57 & 0.45 & 0.44 & 1.0 & 0.15 & 0.45 & 0.65 & 0.31 & 0.75 & 0.18 & -0.10 \\
\hline Iron & 0.03 & 0.13 & 0.15 & 0.10 & 0.09 & 0.11 & -0.05 & -0.15 & -0.12 & 0.35 & 0.05 & 0.54 & 0.15 & 0.10 & 0.45 & 0.06 & 0.15 & 1.0 & 0.33 & -0.07 & 0.18 & 0.09 & 0.30 & -0.17 \\
\hline Lead & -0.01 & -0.01 & 0.01 & -0.04 & -0.03 & -0.03 & 0.32 & -0.22 & -0.24 & -0.19 & -0.20 & 0.68 & -0.14 & 0.49 & 0.41 & 0.02 & 0.45 & 0.33 & 1.0 & 0.09 & 0.40 & 0.41 & 0.08 & -0.59 \\
\hline Nickel & 0.46 & 0.63 & 0.63 & 0.76 & 0.59 & 0.57 & 0.56 & 0.18 & 0.57 & 0.26 & 0.57 & -0.25 & 0.73 & 0.69 & 0.33 & 0.91 & 0.65 & -0.07 & 0.09 & 1.0 & 0.17 & 0.77 & 0.45 & 0.04 \\
\hline Silver & 0.27 & -0.02 & -0.10 & 0.11 & -0.10 & -0.10 & 0.46 & -0.32 & -0.23 & -0.03 & 0.08 & 0.21 & -0.05 & 0.14 & 0.11 & 0.13 & 0.31 & 0.18 & 0.40 & 0.17 & 1.0 & 0.16 & 0.12 & -0.55 \\
\hline Uranium & 0.25 & 0.56 & 0.58 & 0.65 & 0.54 & 0.54 & 0.48 & 0.11 & 0.22 & 0.14 & 0.31 & 0.13 & 0.42 & 0.89 & 0.47 & 0.60 & 0.75 & 0.09 & 0.41 & 0.77 & 0.16 & 1.0 & 0.47 & 0.05 \\
\hline Zinc & 0.06 & 0.09 & 0.22 & 0.28 & 0.16 & 0.16 & 0.19 & -0.10 & 0.22 & 0.19 & 0.05 & 0.34 & 0.20 & 0.54 & 0.37 & 0.53 & 0.18 & 0.30 & 0.08 & 0.45 & 0.12 & 0.47 & 1.0 & 0.27 \\
\hline Water Depth & -0.03 & -0.03 & 0.05 & 0.02 & 0.13 & 0.13 & -0.28 & 0.32 & 0.19 & 0.22 & 0.01 & -0.26 & 0.16 & 0.03 & -0.02 & 0.09 & -0.10 & -0.17 & -0.59 & 0.04 & -0.55 & 0.05 & 0.27 & 1.0 \\
\hline
\end{tabular}



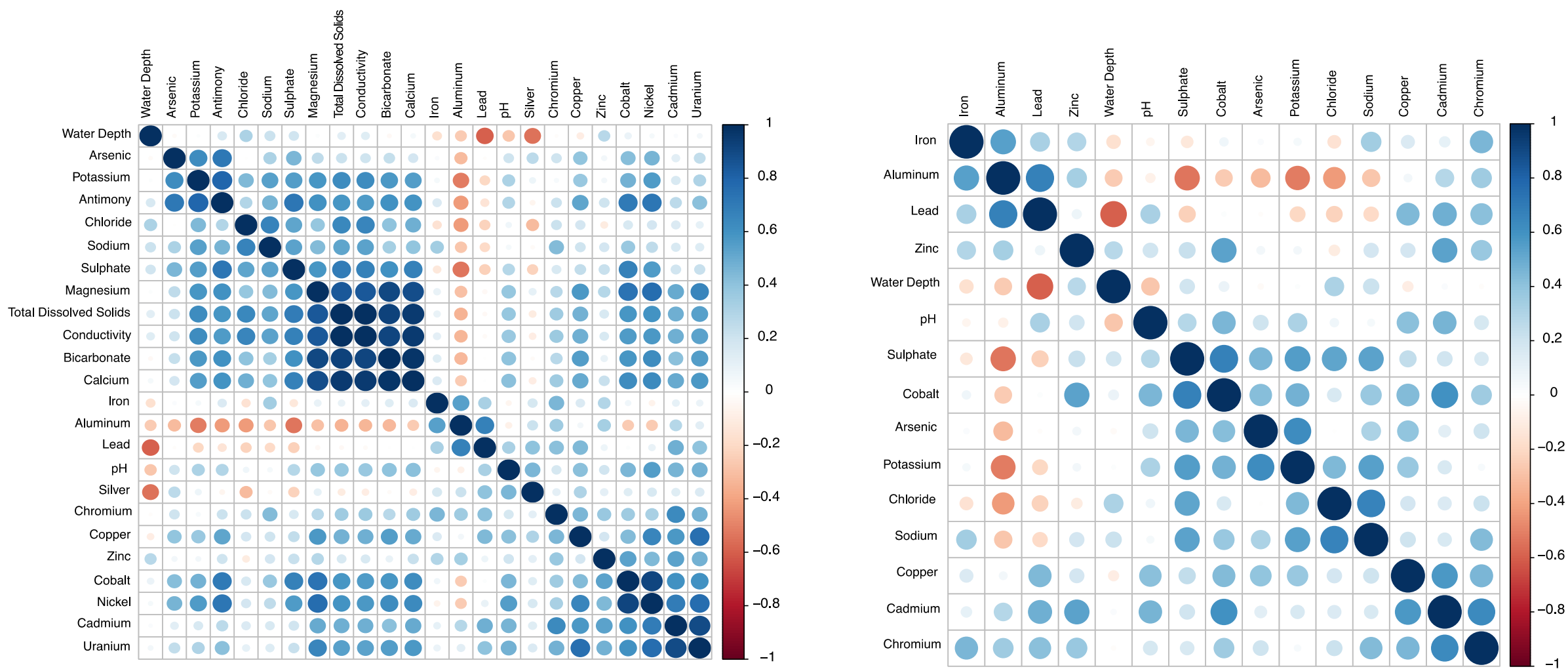

Figure 6-1: Corrplot matrices corresponding to the correlation between chemical and environmental variables sampled in the 24-lake gradient. Bigger circles correspond to higher rates of correlation, with red colours relating to negative relationships and blue colours corresponding with positive relationships. The matrix on the left shows all of the raw chemical and environmental variables sampled from the Cobalt, Ontario region, while the matrix on the right showcases the remaining variables after those with $\geq 0.70$ correlation were removed. 
Table 6-4: Correlation matrix between computed PCA site scores and reduced environmental variables sampled in the 24-lake gradient from 2015. Cells highlighted red represent site scores or variables which are $\geq 0.70$ correlated with one another.

\begin{tabular}{|c|c|c|c|c|c|c|c|c|c|c|c|c|c|c|c|c|c|c|c|c|}
\hline $\begin{array}{c}\text { Environmental } \\
\text { Variables }\end{array}$ & $\bar{U}$ & Uี & లِ & ঠ் & $\bigcup_{2}^{10}$ & $\bigcup_{0}^{0}$ & 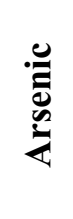 & $\frac{\pi}{2}$ & $\frac{\stackrel{0}{e}}{\stackrel{0}{e}}$ & 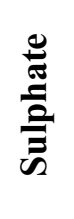 & $\underset{\Xi}{\Xi}$ & 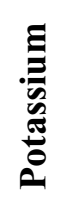 & 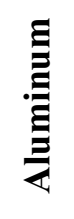 & 态 & 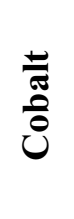 & $\frac{\grave{d}}{\grave{o}}$ & อี & త్త్త & 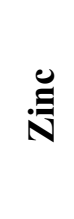 & 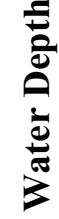 \\
\hline PC1 & 1.00 & 0.00 & 0.00 & 0.00 & 0.00 & 0.00 & -0.17 & -0.40 & 0.27 & 0.25 & 0.30 & -0.12 & -0.34 & -0.04 & 0.11 & -0.21 & -0.10 & -0.48 & 0.07 & 0.60 \\
\hline PC2 & 0.00 & 1.00 & 0.00 & 0.00 & 0.00 & 0.00 & -0.10 & -0.11 & 0.01 & -0.15 & -0.40 & -0.22 & 0.21 & -0.10 & -0.31 & 0.01 & -0.04 & 0.17 & -0.14 & 0.26 \\
\hline PC3 & 0.00 & 0.00 & 1.00 & 0.00 & 0.00 & 0.00 & 0.30 & 0.43 & 0.29 & 0.44 & -0.02 & 0.27 & -0.45 & 0.20 & 0.26 & 0.32 & -0.49 & -0.14 & -0.13 & 0.16 \\
\hline PC4 & 0.00 & 0.00 & 0.00 & 1.00 & 0.00 & 0.00 & 0.14 & -0.02 & -0.13 & -0.03 & 0.02 & 0.21 & 0.02 & -0.16 & 0.00 & 0.43 & 0.31 & 0.10 & -0.12 & -0.09 \\
\hline PC5 & 0.00 & 0.00 & 0.00 & 0.00 & 1.00 & 0.00 & 0.11 & -0.13 & 0.03 & 0.38 & -0.03 & -0.09 & -0.11 & -0.15 & 0.09 & -0.12 & -0.07 & -0.04 & -0.11 & -0.18 \\
\hline PC6 & 0.00 & 0.00 & 0.00 & 0.00 & 0.00 & 1.00 & 0.22 & 0.35 & 0.14 & 0.25 & 0.13 & 0.31 & -0.13 & 0.48 & 0.49 & 0.37 & -0.11 & 0.10 & 0.26 & 0.07 \\
\hline Arsenic & -0.17 & -0.10 & 0.30 & 0.14 & 0.11 & 0.22 & 1.00 & 0.20 & -0.01 & 0.46 & 0.32 & 0.63 & -0.32 & 0.13 & 0.42 & 0.39 & 0.03 & -0.01 & 0.06 & -0.03 \\
\hline pH & -0.40 & -0.11 & 0.43 & -0.02 & -0.13 & 0.35 & 0.20 & 1.00 & 0.07 & 0.28 & 0.05 & 0.31 & -0.08 & 0.46 & 0.46 & 0.42 & -0.05 & 0.32 & 0.19 & -0.28 \\
\hline Chloride & 0.27 & 0.01 & 0.29 & -0.13 & 0.03 & 0.14 & -0.01 & 0.07 & 1.00 & 0.53 & 0.66 & 0.45 & -0.42 & 0.16 & 0.17 & 0.19 & -0.15 & -0.22 & -0.10 & 0.32 \\
\hline Sulphate & 0.25 & -0.15 & 0.44 & -0.03 & 0.38 & 0.25 & 0.46 & 0.28 & 0.53 & 1.00 & 0.53 & 0.56 & -0.54 & 0.20 & 0.68 & 0.24 & -0.12 & -0.24 & 0.23 & 0.19 \\
\hline Sodium & 0.30 & -0.40 & -0.02 & 0.02 & -0.03 & 0.13 & 0.32 & 0.05 & 0.66 & 0.53 & 1.00 & 0.54 & -0.27 & 0.16 & 0.37 & 0.20 & 0.35 & -0.19 & 0.19 & 0.22 \\
\hline Potassium & -0.12 & -0.22 & 0.27 & 0.21 & -0.09 & 0.31 & 0.63 & 0.31 & 0.45 & 0.56 & 0.54 & 1.00 & -0.51 & 0.16 & 0.47 & 0.38 & 0.05 & -0.20 & 0.05 & 0.01 \\
\hline Aluminum & -0.34 & 0.21 & -0.45 & 0.02 & -0.11 & -0.13 & -0.32 & -0.08 & -0.42 & -0.54 & -0.27 & -0.51 & 1.00 & 0.29 & -0.25 & 0.06 & 0.54 & 0.68 & 0.34 & -0.26 \\
\hline Cadmium & -0.04 & -0.10 & 0.20 & -0.16 & -0.15 & 0.48 & 0.13 & 0.46 & 0.16 & 0.20 & 0.16 & 0.16 & 0.29 & 1.00 & 0.61 & 0.57 & 0.10 & 0.49 & 0.54 & 0.03 \\
\hline Cobalt & 0.11 & -0.31 & 0.26 & 0.00 & 0.09 & 0.49 & 0.42 & 0.46 & 0.17 & 0.68 & 0.37 & 0.47 & -0.25 & 0.61 & 1.00 & 0.44 & 0.06 & 0.02 & 0.53 & 0.09 \\
\hline Copper & -0.21 & 0.01 & 0.32 & 0.43 & -0.12 & 0.37 & 0.39 & 0.42 & 0.19 & 0.24 & 0.20 & 0.38 & 0.06 & 0.57 & 0.44 & 1.00 & 0.15 & 0.45 & 0.18 & -0.10 \\
\hline Iron & -0.10 & -0.04 & -0.49 & 0.31 & -0.07 & -0.11 & 0.03 & -0.05 & -0.15 & -0.12 & 0.35 & 0.05 & 0.54 & 0.10 & 0.06 & 0.15 & 1.00 & 0.33 & 0.30 & -0.17 \\
\hline Lead & -0.48 & 0.17 & -0.14 & 0.10 & -0.04 & 0.10 & -0.01 & 0.32 & -0.22 & -0.24 & -0.19 & -0.20 & 0.68 & 0.49 & 0.02 & 0.45 & 0.33 & 1.00 & 0.08 & -0.59 \\
\hline Zinc & 0.07 & -0.14 & -0.13 & -0.12 & -0.11 & 0.26 & 0.06 & 0.19 & -0.10 & 0.23 & 0.19 & 0.05 & 0.34 & 0.54 & 0.53 & 0.18 & 0.30 & 0.08 & 1.00 & 0.27 \\
\hline Water Depth & 0.60 & 0.26 & 0.16 & -0.09 & -0.18 & 0.07 & -0.03 & -0.28 & 0.32 & 0.19 & 0.22 & 0.01 & -0.26 & 0.03 & 0.09 & -0.10 & -0.17 & -0.59 & 0.27 & 1.00 \\
\hline
\end{tabular}




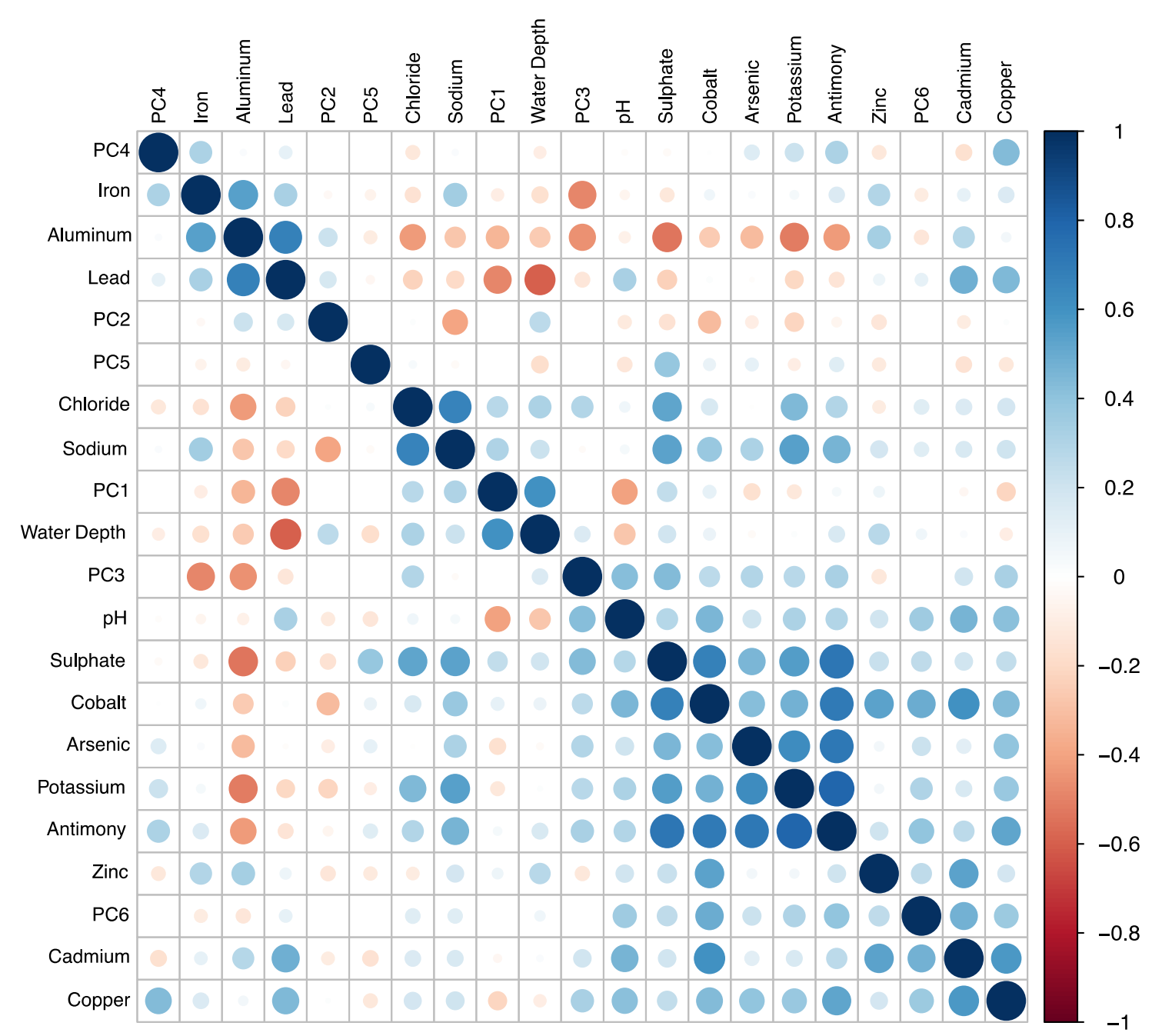

Figure 6-2: Corrplot matrix corresponding to the correlation between computed PCA site scores and environmental variables sampled in the 24-lake gradient. Bigger circles correspond to higher rates of correlation, with red colours relating to negative relationships and blue colours corresponding with positive relationships. 
Table 6-5: Correlation matrix for the raw 10-lake surface water data sampled in 2017 . All variables found to have correlation of $\geq 0.70$ with one another were removed from further statistical analysis.

\begin{tabular}{|c|c|c|c|c|c|c|c|c|c|c|c|c|c|c|c|c|c|c|c|c|}
\hline $\begin{array}{c}\text { Environmental } \\
\text { Variables }\end{array}$ & 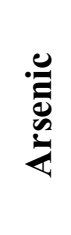 & & $\underset{\Xi}{\Xi}$ & $\stackrel{\gtrsim}{\stackrel{\Xi}{\Xi}}$ & 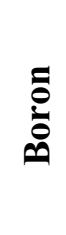 & 氕 & 异 & 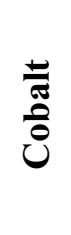 & $\frac{\grave{0}}{\grave{o}}$ & อี & $\stackrel{\text { త్ర }}{\text { త్ర }}$ & 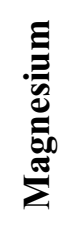 & 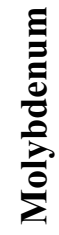 & $\frac{\bar{D}}{\frac{x}{0}}$ & $\frac{\vdots}{\overline{0}}$ & 兰 & 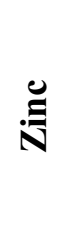 & $\frac{\pi}{2}$ & $\underset{2}{2}$ & 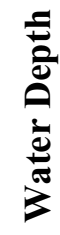 \\
\hline Arsenic & 1.00 & 0.71 & -0.17 & 0.96 & 0.79 & 0.33 & 0.65 & 0.46 & 0.81 & 0.03 & 0.19 & 0.80 & 0.92 & 0.77 & 0.49 & 0.79 & 0.54 & 0.26 & 0.39 & -0.15 \\
\hline Hardness & 0.71 & 1.00 & -0.49 & 0.79 & 0.87 & 0.42 & 0.99 & 0.84 & 0.41 & -0.41 & 0.11 & 0.95 & 0.76 & 0.92 & 0.02 & 0.78 & 0.69 & 0.23 & -0.14 & 0.28 \\
\hline Aluminum & -0.17 & -0.49 & 1.00 & -0.14 & -0.27 & -0.27 & -0.51 & -0.28 & 0.15 & 0.46 & 0.04 & -0.41 & -0.10 & -0.24 & 0.08 & -0.04 & -0.10 & 0.50 & 0.30 & -0.32 \\
\hline Antimony & 0.96 & 0.79 & -0.14 & 1.00 & 0.90 & 0.32 & 0.74 & 0.53 & 0.72 & -0.02 & 0.18 & 0.84 & 0.96 & 0.82 & 0.37 & 0.84 & 0.60 & 0.31 & 0.26 & -0.07 \\
\hline Boron & 0.79 & 0.87 & -0.27 & 0.90 & 1.00 & 0.39 & 0.84 & 0.65 & 0.41 & -0.29 & 0.10 & 0.90 & 0.84 & 0.85 & 0.09 & 0.79 & 0.71 & 0.26 & -0.12 & 0.28 \\
\hline Cadmium & 0.33 & 0.42 & -0.27 & 0.32 & 0.39 & 1.00 & 0.43 & 0.22 & 0.44 & -0.50 & 0.73 & 0.36 & 0.19 & 0.32 & -0.19 & 0.06 & 0.21 & 0.30 & -0.37 & 0.36 \\
\hline Calcium & 0.65 & 0.99 & -0.51 & 0.74 & 0.84 & 0.43 & 1.00 & 0.80 & 0.39 & -0.44 & 0.16 & 0.90 & 0.73 & 0.88 & -0.02 & 0.75 & 0.63 & 0.24 & -0.18 & 0.28 \\
\hline Cobalt & 0.46 & 0.84 & -0.28 & 0.53 & 0.65 & 0.22 & 0.80 & 1.00 & 0.20 & -0.34 & -0.11 & 0.86 & 0.52 & 0.91 & 0.01 & 0.66 & 0.86 & 0.32 & -0.12 & 0.31 \\
\hline Copper & 0.81 & 0.41 & 0.15 & 0.72 & 0.41 & 0.44 & 0.39 & 0.20 & 1.00 & 0.18 & 0.53 & 0.44 & 0.71 & 0.51 & 0.50 & 0.57 & 0.25 & 0.49 & 0.52 & -0.38 \\
\hline Iron & 0.03 & -0.41 & 0.46 & -0.02 & -0.29 & -0.50 & -0.44 & -0.34 & 0.18 & 1.00 & 0.04 & -0.33 & 0.07 & -0.27 & 0.64 & -0.04 & -0.11 & -0.02 & 0.82 & -0.67 \\
\hline Lead & 0.19 & 0.11 & 0.04 & 0.18 & 0.10 & 0.73 & 0.16 & -0.11 & 0.53 & 0.04 & 1.00 & -0.02 & 0.19 & 0.01 & 0.22 & -0.07 & 0.00 & 0.52 & -0.06 & -0.16 \\
\hline Magnesium & 0.80 & 0.95 & -0.41 & 0.84 & 0.90 & 0.36 & 0.90 & 0.86 & 0.44 & -0.33 & -0.02 & 1.00 & 0.78 & 0.97 & 0.13 & 0.81 & 0.80 & 0.20 & -0.01 & 0.27 \\
\hline Molybdenum & 0.92 & 0.76 & -0.10 & 0.96 & 0.84 & 0.19 & 0.73 & 0.52 & 0.71 & 0.07 & 0.19 & 0.78 & 1.00 & 0.79 & 0.51 & 0.89 & 0.61 & 0.41 & 0.29 & -0.16 \\
\hline Nickel & 0.77 & 0.92 & -0.24 & 0.82 & 0.85 & 0.32 & 0.88 & 0.91 & 0.51 & -0.27 & 0.01 & 0.97 & 0.79 & 1.00 & 0.17 & 0.87 & 0.85 & 0.37 & 0.03 & 0.23 \\
\hline Silver & 0.49 & 0.02 & 0.08 & 0.37 & 0.09 & -0.19 & -0.02 & 0.01 & 0.50 & 0.64 & 0.22 & 0.13 & 0.51 & 0.17 & 1.00 & 0.29 & 0.32 & 0.29 & 0.62 & -0.62 \\
\hline Uranium & 0.79 & 0.78 & -0.04 & 0.84 & 0.79 & 0.06 & 0.75 & 0.66 & 0.57 & -0.04 & -0.07 & 0.81 & 0.89 & 0.87 & 0.29 & 1.00 & 0.68 & 0.37 & 0.22 & 0.10 \\
\hline Zinc & 0.54 & 0.69 & -0.10 & 0.60 & 0.71 & 0.21 & 0.63 & 0.86 & 0.25 & -0.11 & 0.00 & 0.80 & 0.61 & 0.85 & 0.32 & 0.68 & 1.00 & 0.47 & -0.06 & 0.28 \\
\hline pH & 0.26 & 0.23 & 0.50 & 0.31 & 0.26 & 0.30 & 0.24 & 0.32 & 0.49 & -0.02 & 0.52 & 0.20 & 0.41 & 0.37 & 0.29 & 0.37 & 0.47 & 1.00 & -0.09 & -0.16 \\
\hline PAR & 0.39 & -0.14 & 0.30 & 0.26 & -0.12 & -0.37 & -0.18 & -0.12 & 0.52 & 0.82 & -0.06 & -0.01 & 0.29 & 0.03 & 0.62 & 0.22 & -0.06 & -0.09 & 1.00 & -0.68 \\
\hline Water Depth & -0.15 & 0.28 & -0.32 & -0.07 & 0.28 & 0.36 & 0.28 & 0.31 & -0.38 & -0.67 & -0.16 & 0.27 & -0.16 & 0.23 & -0.62 & 0.10 & 0.28 & -0.16 & -0.68 & 1.00 \\
\hline
\end{tabular}




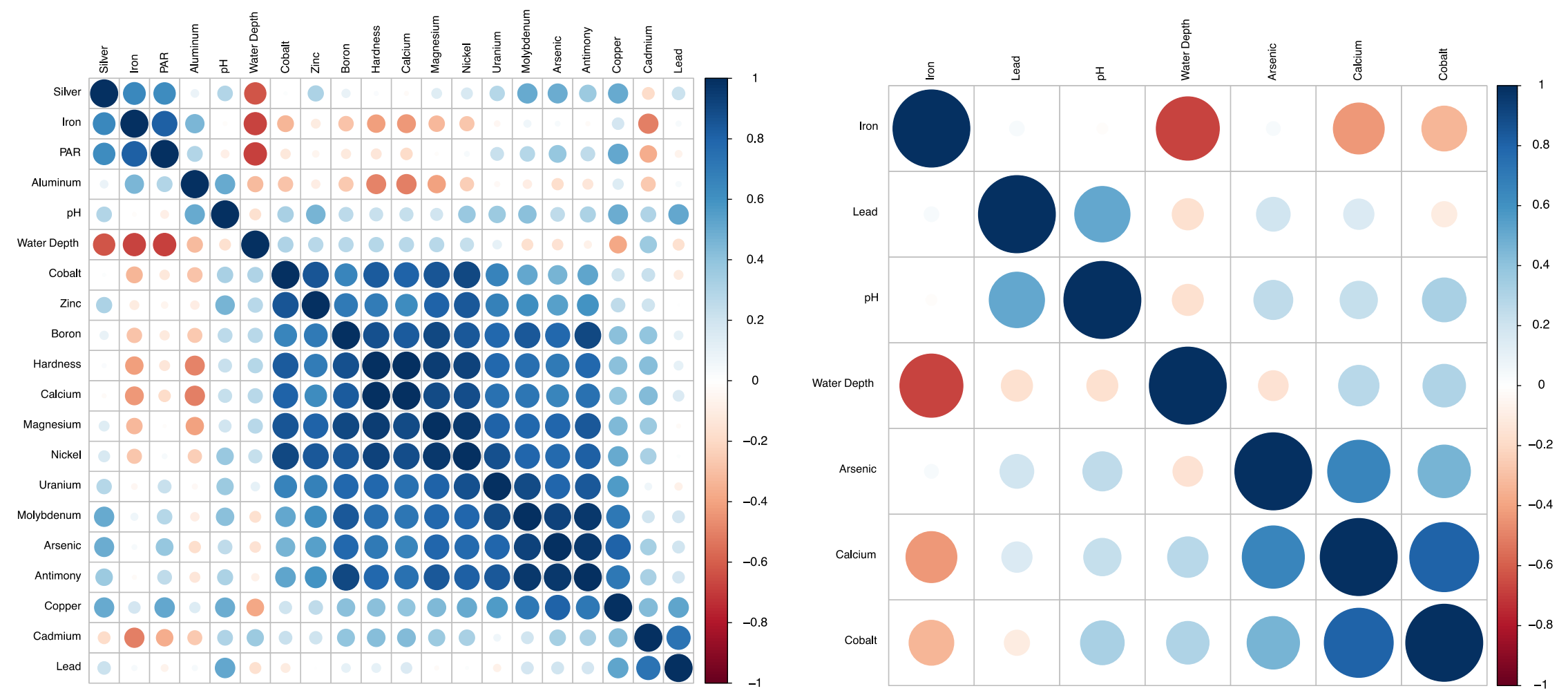

Figure 6-3: Corrplot matrices corresponding to the correlation between chemical and environmental variables sampled in the 10-lake gradient. Bigger circles correspond to higher rates of correlation, with red colours relating to negative relationships and blue colours corresponding with positive relationships. The matrix on the left shows all of the raw chemical and environmental variables sampled from the Cobalt, Ontario region, while the matrix on the right showcases the remaining variables after those with $\geq 0.70$ correlation were removed. 
Table 6-6: Correlation matrix between computed PCA site scores for cladocera and reduced environmental variables sampled in the 10 -lake gradient from 2017. Cells highlighted red represent site scores or variables which are $\geq 0.70$ correlated with one another.

\begin{tabular}{|c|c|c|c|c|c|c|c|c|c|c|c|c|c|}
\hline $\begin{array}{l}\text { Environmental } \\
\text { Variables }\end{array}$ & $\bar{u}$ & ల̃ & $\bigcup^{M}$ & ¿ & Un & $\bigcup_{0}^{0}$ & 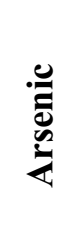 & 苞 & 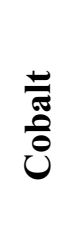 & อี & 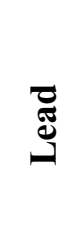 & 竞 & 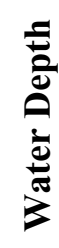 \\
\hline PC1 & 1.00 & 0.00 & 0.00 & 0.00 & 0.00 & 0.00 & -0.46 & -0.33 & 0.09 & -0.48 & -0.50 & -0.23 & 0.11 \\
\hline PC2 & 0.00 & 1.00 & 0.00 & 0.00 & 0.00 & 0.00 & 0.08 & 0.58 & -0.05 & -0.41 & -0.03 & -0.13 & 0.52 \\
\hline PC3 & 0.00 & 0.00 & 1.00 & 0.00 & 0.00 & 0.00 & -0.62 & -0.27 & 0.20 & 0.18 & 0.11 & 0.36 & -0.11 \\
\hline PC4 & 0.00 & 0.00 & 0.00 & 1.00 & 0.00 & 0.00 & 0.48 & 0.29 & 0.39 & -0.09 & 0.49 & 0.75 & -0.28 \\
\hline PC5 & 0.00 & 0.00 & 0.00 & 0.00 & 1.00 & 0.00 & -0.03 & -0.53 & -0.65 & 0.18 & -0.20 & 0.31 & 0.12 \\
\hline PC6 & 0.00 & 0.00 & 0.00 & 0.00 & 0.00 & 1.00 & -0.29 & -0.32 & -0.24 & 0.19 & -0.06 & -0.15 & 0.53 \\
\hline Arsenic & -0.46 & 0.08 & -0.62 & 0.48 & -0.03 & -0.29 & 1.00 & 0.62 & 0.21 & 0.18 & 0.28 & 0.23 & -0.40 \\
\hline Calcium & -0.33 & 0.58 & -0.27 & 0.29 & -0.53 & -0.32 & 0.62 & 1.00 & 0.50 & -0.27 & 0.30 & 0.05 & -0.06 \\
\hline Cobalt & 0.09 & -0.05 & 0.20 & 0.39 & -0.65 & -0.24 & 0.21 & 0.50 & 1.00 & 0.11 & -0.07 & 0.31 & -0.61 \\
\hline Iron & -0.48 & -0.41 & 0.18 & -0.09 & 0.18 & 0.19 & 0.18 & -0.27 & 0.11 & 1.00 & -0.17 & 0.16 & -0.54 \\
\hline Lead & -0.50 & -0.03 & 0.11 & 0.49 & -0.20 & -0.06 & 0.28 & 0.30 & -0.07 & -0.17 & 1.00 & 0.34 & 0.04 \\
\hline pH & -0.23 & -0.13 & 0.36 & 0.75 & 0.31 & -0.15 & 0.23 & 0.05 & 0.31 & 0.16 & 0.34 & 1.00 & -0.38 \\
\hline Water Depth & 0.11 & 0.52 & -0.11 & -0.28 & 0.12 & 0.53 & -0.40 & -0.06 & -0.61 & -0.54 & 0.04 & -0.38 & 1.00 \\
\hline
\end{tabular}




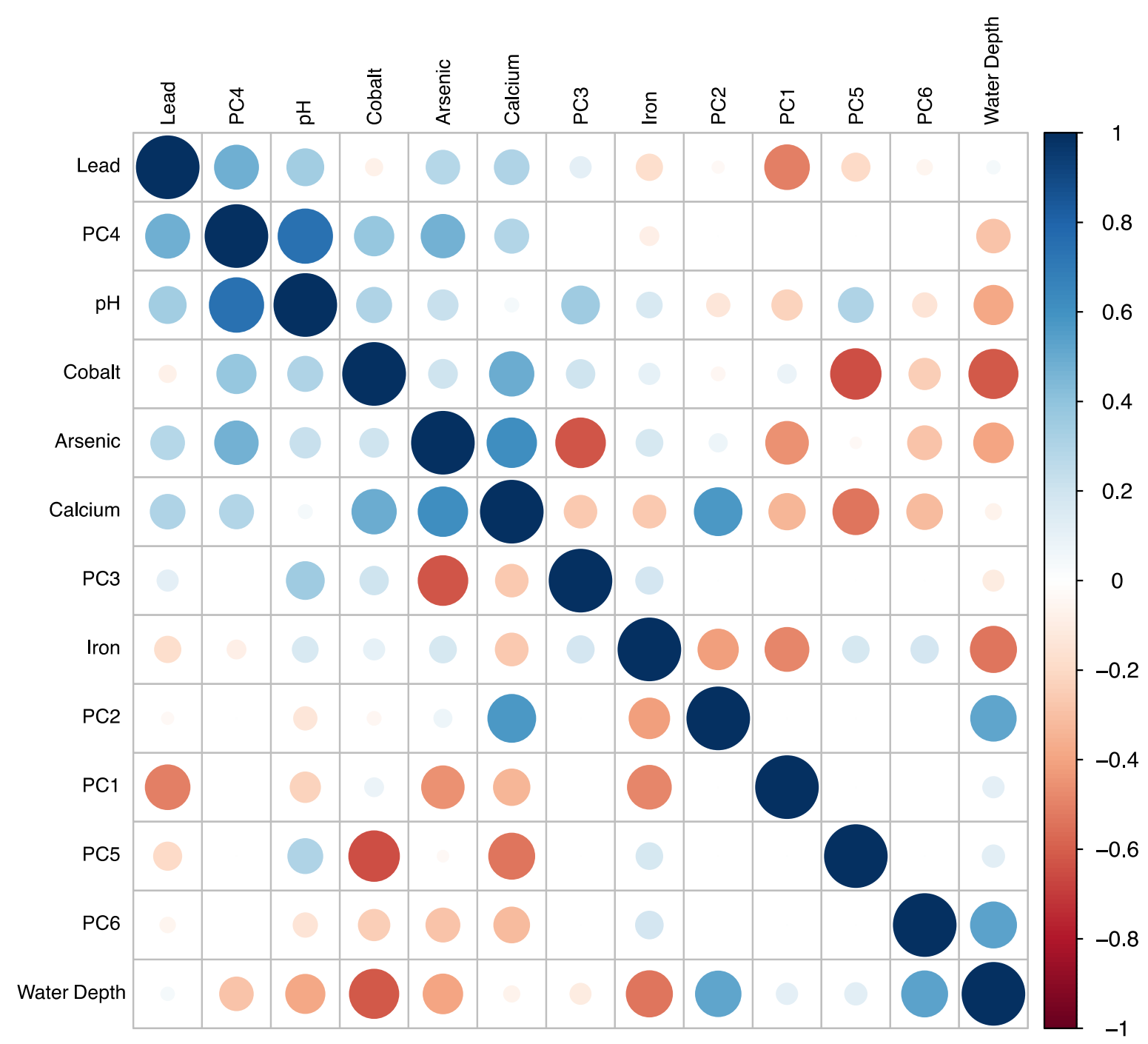

Figure 6-4: Corrplot matrix corresponding to the correlation between computed PCA site scores for cladocera and environmental variables sampled in 2017 along the 10-lake gradient. Bigger circles correspond to higher rates of correlation, with red colours relating to negative relationships and blue colours corresponding with positive relationships. 
Table 6-7: Correlation matrix between computed PCA site scores for chironomids and reduced environmental variables sampled in the 10-lake gradient from 2017. Cells highlighted red represent site scores or variables which are $\geq 0.70$ correlated with one another.

\begin{tabular}{|c|c|c|c|c|c|c|c|c|c|c|c|c|c|}
\hline $\begin{array}{c}\text { Environmental } \\
\text { Variables }\end{array}$ & 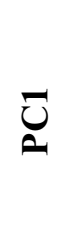 & $\underset{1}{N}$ & $\bigcup^{m}$ & $\bigcup^{+}$ & $\bigcup_{2}^{n}$ & $\underset{1}{0}$ & 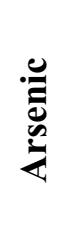 & 胥 & $\begin{array}{l}\frac{\varpi}{\tilde{I}} \\
\frac{0}{0}\end{array}$ & อี & 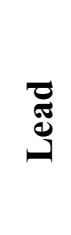 & $\frac{\pi}{2}$ & 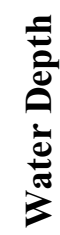 \\
\hline PC1 & 1.00 & 0.00 & 0.00 & 0.00 & 0.00 & 0.00 & 0.02 & 0.00 & 0.31 & 0.29 & 0.08 & 0.20 & -0.01 \\
\hline PC2 & 0.00 & 1.00 & 0.00 & 0.00 & 0.00 & 0.00 & 0.21 & 0.43 & 0.41 & 0.02 & 0.44 & 0.76 & -0.27 \\
\hline PC3 & 0.00 & 0.00 & 1.00 & 0.00 & 0.00 & 0.00 & -0.06 & 0.33 & -0.07 & -0.47 & 0.19 & -0.07 & 0.22 \\
\hline PC4 & 0.00 & 0.00 & 0.00 & 1.00 & 0.00 & 0.00 & -0.20 & -0.49 & -0.49 & 0.46 & 0.06 & 0.12 & -0.81 \\
\hline PC5 & 0.00 & 0.00 & 0.00 & 0.00 & 1.00 & 0.00 & -0.31 & -0.21 & -0.09 & -0.51 & 0.44 & 0.31 & 0.24 \\
\hline PC6 & 0.00 & 0.00 & 0.00 & 0.00 & 0.00 & 1.00 & -0.49 & -0.03 & 0.29 & -0.31 & -0.62 & 0.06 & 0.34 \\
\hline Arsenic & 0.02 & 0.21 & -0.06 & -0.20 & -0.31 & -0.49 & 1.00 & 0.65 & 0.46 & 0.03 & 0.19 & 0.26 & -0.15 \\
\hline Calcium & 0.00 & 0.43 & 0.33 & -0.49 & -0.21 & -0.03 & 0.65 & 1.00 & 0.80 & -0.44 & 0.16 & 0.24 & 0.28 \\
\hline Cobalt & 0.31 & 0.41 & -0.07 & -0.49 & -0.09 & 0.29 & 0.46 & 0.80 & 1.00 & -0.34 & -0.11 & 0.32 & 0.31 \\
\hline Iron & 0.29 & 0.02 & -0.47 & 0.46 & -0.51 & -0.31 & 0.03 & -0.44 & -0.34 & 1.00 & 0.04 & -0.02 & -0.67 \\
\hline Lead & 0.08 & 0.44 & 0.19 & 0.06 & 0.44 & -0.62 & 0.19 & 0.16 & -0.11 & 0.04 & 1.00 & 0.52 & -0.16 \\
\hline pH & 0.20 & 0.76 & -0.07 & 0.12 & 0.31 & 0.06 & 0.26 & 0.24 & 0.32 & -0.02 & 0.52 & 1.00 & -0.16 \\
\hline Water Depth & -0.01 & -0.27 & 0.22 & -0.81 & 0.24 & 0.34 & -0.15 & 0.28 & 0.31 & -0.67 & -0.16 & -0.16 & 1.00 \\
\hline
\end{tabular}




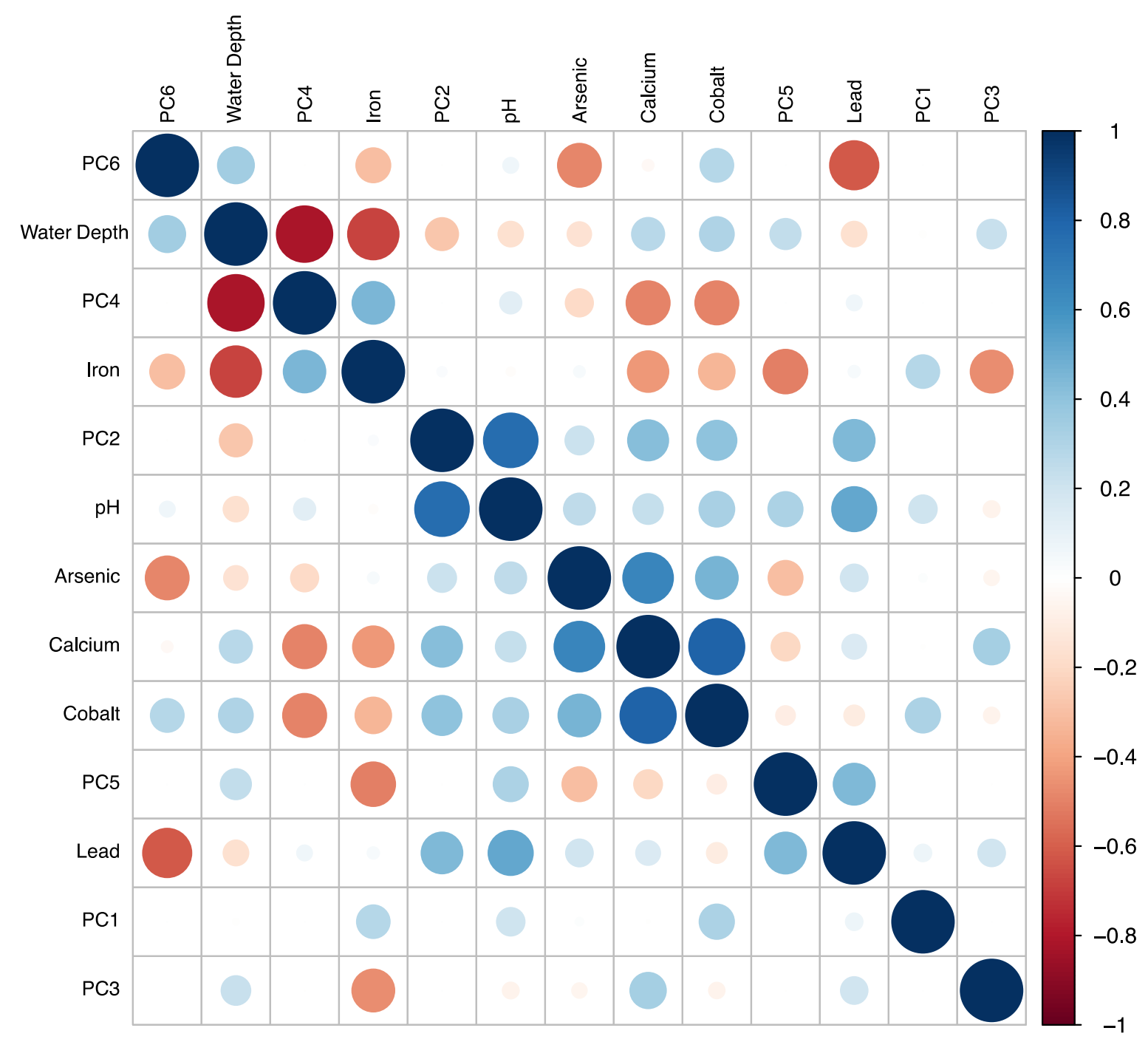

Figure 6-5: Corrplot matrix corresponding to the correlation between computed PCA site scores for chironomid and environmental variables sampled in 2017 along the 10-lake gradient. Bigger circles correspond to higher rates of correlation, with red colours relating to negative relationships and blue colours corresponding with positive relationships. 
Table 6-8: Correlation matrix between computed PCA site scores for zooplankton and reduced environmental variables sampled in the 10-lake gradient from 2017. Cells highlighted red represent site scores or variables which are $\geq 0.70$ correlated with one another.

\begin{tabular}{|c|c|c|c|c|c|c|c|c|c|c|c|c|c|}
\hline $\begin{array}{c}\text { Environmental } \\
\text { Variables }\end{array}$ & $\tilde{U}$ & U & $\bigcup_{1}^{\infty}$ & ப் & en & $\underset{1}{0}$ & 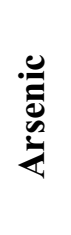 & $\underset{\Xi}{\frac{\Xi}{\tilde{J}}}$ & $\begin{array}{l}\frac{\text { ప }}{0} \\
\stackrel{0}{0}\end{array}$ & อี & త్ర త్త & $\frac{\pi}{2}$ & 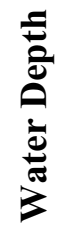 \\
\hline PC1 & 1.00 & 0.00 & 0.00 & 0.00 & 0.00 & 0.00 & 0.11 & 0.44 & 0.56 & -0.38 & 0.43 & 0.50 & 0.48 \\
\hline PC2 & 0.00 & 1.00 & 0.00 & 0.00 & 0.00 & 0.00 & 0.12 & 0.17 & 0.10 & -0.47 & -0.27 & 0.09 & 0.03 \\
\hline PC3 & 0.00 & 0.00 & 1.00 & 0.00 & 0.00 & 0.00 & 0.75 & 0.69 & 0.44 & -0.26 & -0.03 & 0.10 & 0.14 \\
\hline PC4 & 0.00 & 0.00 & 0.00 & 1.00 & 0.00 & 0.00 & 0.37 & -0.08 & 0.20 & 0.56 & -0.35 & 0.13 & -0.01 \\
\hline PC5 & 0.00 & 0.00 & 0.00 & 0.00 & 1.00 & 0.00 & -0.16 & -0.49 & -0.54 & 0.08 & 0.27 & -0.08 & -0.47 \\
\hline PC6 & 0.00 & 0.00 & 0.00 & 0.00 & 0.00 & 1.00 & -0.49 & -0.03 & 0.24 & -0.30 & -0.70 & -0.33 & 0.48 \\
\hline Arsenic & 0.11 & 0.12 & 0.75 & 0.37 & -0.16 & -0.49 & 1.00 & 0.65 & 0.46 & 0.03 & 0.18 & 0.31 & 0.00 \\
\hline Calcium & 0.44 & 0.17 & 0.69 & -0.08 & -0.49 & -0.03 & 0.65 & 1.00 & 0.80 & -0.44 & 0.05 & 0.26 & 0.47 \\
\hline Cobalt & 0.56 & 0.10 & 0.44 & 0.20 & -0.54 & 0.24 & 0.46 & 0.80 & 1.00 & -0.34 & -0.22 & 0.33 & 0.57 \\
\hline Iron & -0.38 & -0.47 & -0.26 & 0.56 & 0.08 & -0.30 & 0.03 & -0.44 & -0.34 & 1.00 & -0.05 & 0.01 & -0.61 \\
\hline Lead & 0.43 & -0.27 & -0.03 & -0.35 & 0.27 & -0.70 & 0.18 & 0.05 & -0.22 & -0.05 & 1.00 & 0.22 & -0.17 \\
\hline $\mathbf{p H}$ & 0.50 & 0.09 & 0.10 & 0.13 & -0.08 & -0.33 & 0.31 & 0.26 & 0.33 & 0.01 & 0.22 & 1.00 & 0.03 \\
\hline Water Depth & 0.48 & 0.03 & 0.14 & -0.01 & -0.47 & 0.48 & 0.00 & 0.47 & 0.57 & -0.61 & -0.17 & 0.03 & 1.00 \\
\hline
\end{tabular}




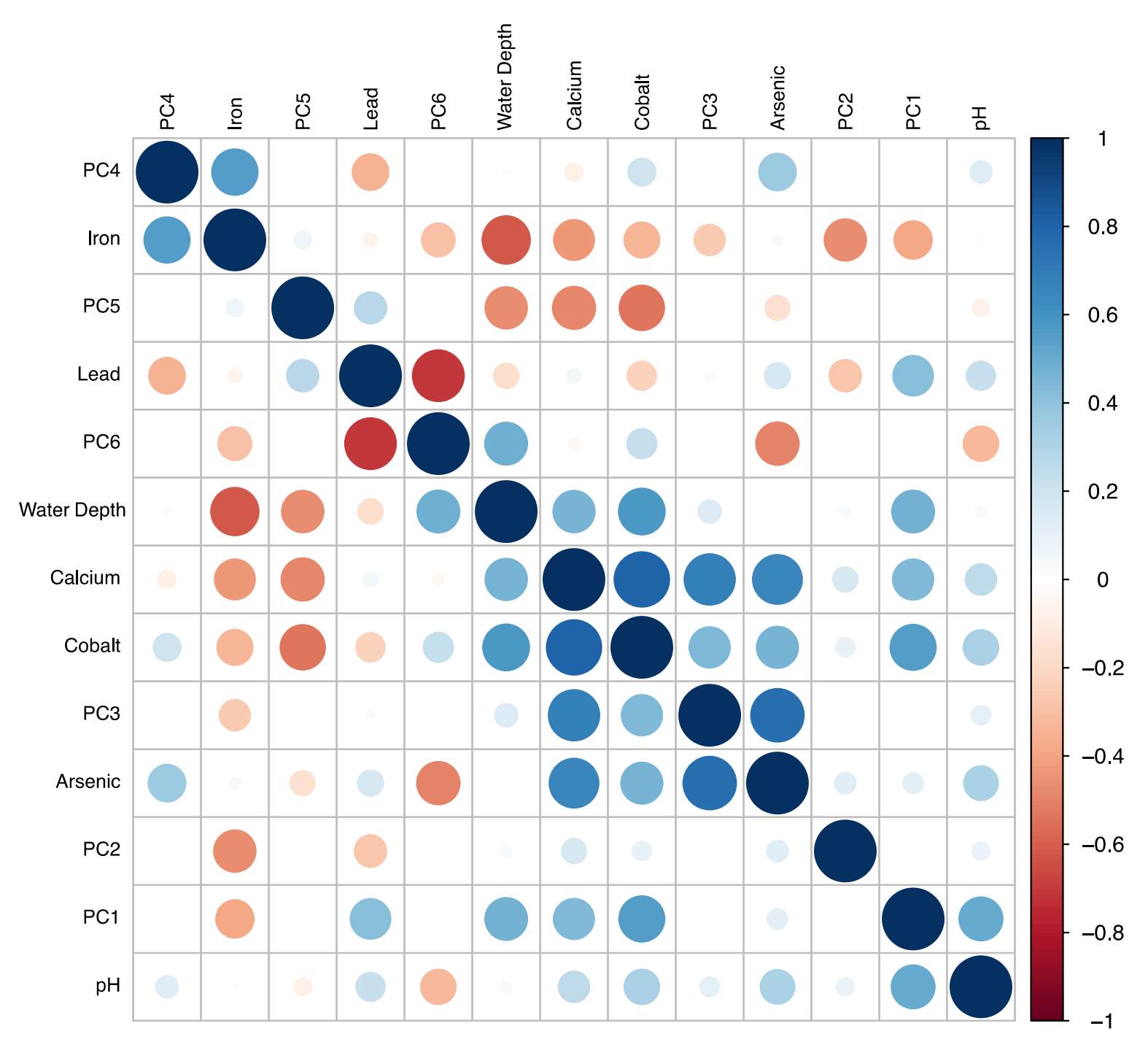

Figure 6-6: Corrplot matrix corresponding to the correlation between computed PCA site scores for zooplankton and environmental variables sampled in 2017 along the 10-lake gradient. Bigger circles correspond to higher rates of correlation, with red colours relating to negative relationships and blue colours corresponding with positive relationships. 


\section{B. BIO-INDICATOR COUNTS \& RELAIVE ABUNDANCES}

Table 6-9: Identified diatom species and their respective count total observed in each lake across the 24-lake arsenic gradient from the Cobalt, Ontario region.

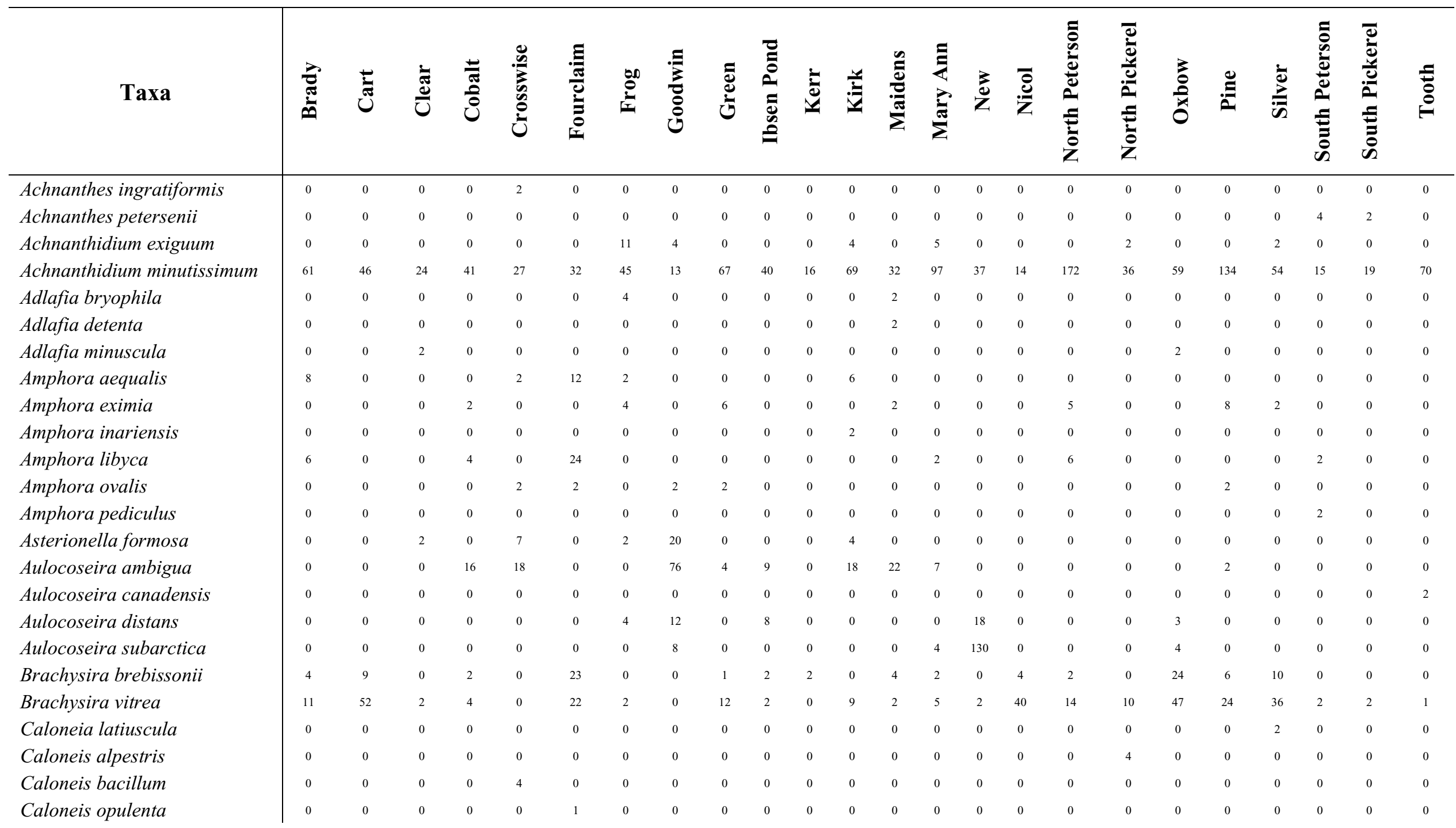


Caloneis silicula

Chamaepinnularia obsolete

Chrysophyte Cyst

Cocconeis neothumensis

Cocconeis placentula

Cocconeis scutellum

Craticula halophile

Craticula subminuscula

Crenotia thermalis

Cyclotella species

Cymbella cistula

Cymbella cymbiformis

Cymbella gracilis

Cymbella heteropleura

Cymbella laevis

Cymbella moelleriana

Cymbella neoleptoceros

Cymbopleura austriaca

Cymbopleura hybrida

Cymbopleura inaequalis

Cymbopleura incerta

Cymbopleura naviculiformis

Denticula kuetzingii

Denticula tenuis

Denticula valida

Diploneis elliptica

Diploneis minuta

Diploneis modica

Diploneis oblongella

Diploneis oculata

Diploneis parma

Diploneis puella

Discotella stelligera

Distrionella incognita

$\mid$\begin{tabular}{l|l}
0 \\
0 \\
0 \\
0 \\
0 \\
0 \\
0 \\
0 \\
0 \\
0 \\
0 \\
0 \\
0 \\
0 \\
0 \\
0 \\
0 \\
0 \\
0 \\
0 \\
0 \\
0 \\
0 \\
0
\end{tabular}


Encyonema gaeumannii Encyonema herbridicum Encyonema leibleinii Encyonema minutum Encyonema perpusillum Encyonopsis cesatii Encyonopsis descripta Encyonopsis falaisensis Encyonopsis microcephala Epithemia gibba

Eucocconeis flexella

Eunotia diodon

Eunotia formica

Eunotia glacialis

Eunotia implicata

Eunotia incisa

Eunotia rhomboidea

Eunotia subarcuatoides

Eunotia sudetica

Eunotia vanheurckii

Fallacia subhamulata

Fragilaria capucina

Fragilaria crotonensis

Fragilaria exigua

Fragilaria tenera

Fragilaria zeilleri

Frustulia rhomboides

Gomphonema acuminatum

Gomphonema amoenum

Gomphonema angustum

Gomphonema aniae

Gomphonema bavaricum

Gomphonema dichotomum

Gomphonema gracile 
Gomphonema gracilis

Gomphonema herbidense

Gomphonema lateripunctatum

Gomphonema olivaceum

Gomphonema

parallelistriatum

Gomphonema parvulum

Gomphonema productum

Gyrosigma acuminatum

Halamphora coffeiformis

Halamphora subcapita

Halamphora thumensis

Hantzschia virgata

Iconella bifrons

Iconella capronii

Iconella hibernica

Iconella linearis

Iconella tenera

Karayevia clevei

Karayevia ploenensis

Karayevia submarina

Lemnicola hungarica

Lindavia bodanica

Lindavia glomerata

Lindavia michiganiana

Lindavia schroeteri

Luticola plausibilis

Mastogloia elliptica

Mastogloia grevillei

Mastogloia smithii

Navicula cryptotonella

Navicula eidrigiana

Navicula erifuga

Navicula laterostrata 
Navicula libonensis

Navicula maceria

Navicula menisculus

Navicula oppugnata

Navicula plausibilis

Navicula radiosa

Navicula shedai

Navicula subadnata

Navicula trivialis

Navicula vulpina

Navicymbula pusilla

Navigiolum ricula

Neidium ampliatum

Neidium iridis

Neidium ladogensis

Neidium productum

Neosynedra delicatissima

Nitzschia amphibia

Nitzschia fonticola

Nitzschia frustulum

Nitzschia graciliformis

Nitzschia gracilis

Nitzschia intermedia

Nitzschia lacuum

Nitzschia liebetruthii

Nitzschia linearis

Nitzschia palea

Nitzschia paleacea

Nitzschia perminuta

Nitzschia radicula

Nitzschia recta

Nitzschia scalpelliformis

Nitzschia sociabilis

Nitzschia tubicola

$\mid$\begin{tabular}{l|l}
4 \\
0 \\
0 \\
0 \\
0 \\
0 \\
0 \\
0 \\
0 \\
0 \\
0 \\
0 \\
1 \\
0 \\
0 \\
0 \\
0 \\
0 \\
0 \\
0 \\
0 \\
0 \\
0 \\
0 \\
0 \\
0 \\
0 \\
6 \\
0 \\
0 \\
0 \\
0 \\
0 \\
0 \\
0
\end{tabular}




\begin{tabular}{|c|c|c|c|c|c|c|c|c|c|c|c|c|c|c|c|c|c|c|c|c|c|c|}
\hline \multirow{2}{*}{$\begin{array}{l}\text { Nupela pennsylvanica } \\
\text { Pantocsekiella comensis }\end{array}$} & 0 & 0 & 0 & 0 & 0 & 0 & 0 & 0 & 0 & 0 & 0 & 0 & 0 & 0 & 0 & 1 & 0 & 0 & 0 & 0 & c & 0 \\
\hline & 11 & 0 & 0 & 0 & 0 & 0 & 0 & 0 & 0 & 0 & 0 & 0 & 0 & 0 & 0 & 0 & 0 & 0 & 0 & 0 & c & 0 \\
\hline Pantocsekiella ocellata & 0 & 0 & 42 & 6 & 8 & 0 & 0 & 12 & 0 & 0 & 0 & 17 & 5 & 0 & 0 & 0 & 0 & 0 & 0 & 0 & c & 0 \\
\hline Pantocsekiella rossii & 0 & 0 & 0 & 0 & 0 & 0 & 0 & 0 & 0 & 0 & 0 & 0 & 0 & 0 & 0 & 0 & 0 & 1 & 0 & 0 & c & 15 \\
\hline Pinnularia brevicostrata & 0 & 0 & 0 & 0 & 0 & 0 & 0 & 0 & 0 & 0 & 0 & 0 & 0 & 0 & 2 & 0 & 0 & 0 & 0 & 0 & c & 0 \\
\hline Pinnularia dactylus & 0 & 0 & 0 & 2 & 2 & 0 & 0 & 0 & 2 & 0 & 0 & 0 & 0 & 4 & 0 & 0 & 0 & 0 & 0 & 0 & c & 0 \\
\hline Pinnularia ignobilis & 0 & 0 & 0 & 0 & 0 & 0 & 0 & 0 & 0 & 0 & 0 & 0 & 0 & 0 & 0 & 0 & 0 & 0 & 0 & 0 & c & 0 \\
\hline Pinnularia interrupta & 0 & 0 & 0 & 15 & 4 & 0 & 0 & 2 & 2 & 0 & 0 & 0 & 0 & 0 & 0 & 0 & 8 & 0 & 4 & 0 & c & 0 \\
\hline Pinnularia karelica & 0 & 0 & 0 & 0 & 0 & 0 & 0 & 0 & 0 & 0 & 0 & 0 & 1 & 0 & 0 & 0 & 0 & 0 & 0 & 0 & c & 0 \\
\hline Pinnularia lundii & 0 & 0 & 0 & 0 & 0 & 0 & 0 & 0 & 0 & 0 & 0 & 0 & 4 & 0 & 0 & 0 & 0 & 0 & 0 & 0 & c & 0 \\
\hline Pinnularia macilenta & 0 & 6 & 0 & 0 & 0 & 0 & 0 & 0 & 0 & 0 & 0 & 0 & 0 & 0 & 0 & 0 & 0 & 0 & 0 & 0 & c & 0 \\
\hline Pinnularia maior & 0 & 0 & 0 & 4 & 0 & 0 & 0 & 0 & 0 & 0 & 0 & 0 & 0 & 0 & 2 & 0 & 0 & 0 & 0 & 0 & c & 0 \\
\hline Pinnularia microstauron & 0 & 0 & 0 & 0 & 0 & 4 & 0 & 0 & 0 & 0 & 17 & 0 & 2 & 2 & 0 & 2 & 0 & 9 & 0 & 4 & c & 6 \\
\hline Pinnularia prolongata & 0 & 0 & 0 & 0 & 0 & 0 & 0 & 0 & 0 & 0 & 0 & 0 & 0 & 0 & 0 & 0 & 2 & 0 & 0 & 0 & c & 0 \\
\hline Pinnularia stomatophora & 0 & 2 & 0 & 0 & 0 & 0 & 0 & 0 & 0 & 0 & 0 & 0 & 0 & 0 & 0 & 0 & 0 & 0 & 0 & 0 & c & 0 \\
\hline Pinnularia subcapita & 6 & 3 & 0 & 4 & 2 & 6 & 0 & 0 & 2 & 2 & 0 & 0 & 0 & 0 & 0 & 0 & 6 & 2 & 2 & 2 & c & 0 \\
\hline Pinnularia viridis & 0 & 4 & 0 & 3 & 0 & 0 & 0 & 0 & 0 & 0 & 0 & 4 & 0 & 0 & 0 & 0 & 2 & 0 & 0 & 0 & c & 0 \\
\hline Placogeia kriegeri & 0 & 4 & 0 & 0 & 0 & 0 & 0 & 0 & 0 & 0 & 0 & 0 & 0 & 0 & 0 & 0 & 0 & 0 & 0 & 0 & c & 0 \\
\hline Placoneis amphibola & 0 & 0 & 0 & 0 & 0 & 0 & 0 & 0 & 2 & 0 & 0 & 0 & 0 & 0 & 0 & 0 & 0 & 0 & 0 & 0 & c & 0 \\
\hline Placoneis constrans & 0 & 0 & 0 & 0 & 0 & 0 & 0 & 0 & 0 & 0 & 0 & 0 & 0 & 0 & 0 & 0 & 0 & 0 & 0 & 0 & c & 0 \\
\hline Placoneis explanata & 0 & 0 & 0 & 0 & 0 & 0 & 0 & 0 & 0 & 0 & 0 & 0 & 0 & 0 & 0 & 0 & 0 & 0 & 0 & 0 & c & 0 \\
\hline Placoneis gastrum & 0 & 0 & 0 & 0 & 2 & 0 & 0 & 0 & 0 & 0 & 0 & 0 & 0 & 0 & 0 & 0 & 0 & 0 & 0 & 0 & c & 0 \\
\hline Planothidium daui & 0 & 0 & 0 & 0 & 6 & 0 & 0 & 0 & 0 & 0 & 0 & 2 & 0 & 0 & 0 & 0 & 0 & 0 & 0 & 0 & c & 0 \\
\hline Planothidium delicatulum & 0 & 8 & 0 & 0 & 0 & 0 & 0 & 0 & 2 & 0 & 0 & 0 & 0 & 2 & 0 & 0 & 0 & 0 & 0 & 0 & c & 0 \\
\hline Planothidium granum & 0 & 0 & 0 & 0 & 0 & 0 & 0 & 0 & 4 & 2 & 0 & 0 & 0 & 0 & 0 & 0 & 0 & 0 & 0 & 0 & 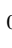 & 0 \\
\hline Planothidium joursacense & 0 & 0 & 2 & 0 & 0 & 0 & 0 & 7 & 0 & 0 & 0 & 0 & 0 & 0 & 0 & 0 & 0 & 0 & 0 & 0 & 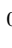 & 0 \\
\hline Planothidium lanceolatum & 0 & 0 & 0 & 0 & 6 & 0 & 29 & 2 & 0 & 0 & 0 & 0 & 0 & 0 & 2 & 0 & 0 & 0 & 0 & 0 & 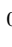 & 2 \\
\hline Planothidium pericavum & 0 & 0 & 0 & 0 & 0 & 0 & 0 & 0 & 0 & 0 & 0 & 0 & 0 & 0 & 0 & 0 & 0 & 0 & 0 & 0 & c & 0 \\
\hline Platessa oblongella & 0 & 0 & 0 & 0 & 0 & 1 & 0 & 0 & 0 & 0 & 0 & 0 & 0 & 0 & 0 & 0 & 0 & 0 & 0 & 0 & c & 0 \\
\hline Platessa ziegleri & 0 & 0 & 0 & 0 & 0 & 0 & 0 & 0 & 0 & 0 & 0 & 0 & 0 & 0 & 0 & 0 & 0 & 0 & 0 & 0 & & 0 \\
\hline Psammothidium helveticum & 0 & 0 & 0 & 0 & 0 & 0 & 0 & 0 & 0 & 0 & 0 & 0 & 0 & 0 & 0 & 0 & 0 & 0 & 0 & 0 & & 0 \\
\hline Psammothidium marginulatum & 6 & 6 & 0 & 4 & 0 & 11 & 12 & 0 & 0 & 0 & 8 & 12 & 0 & 4 & 0 & 4 & 22 & 174 & 2 & 0 & & 2 \\
\hline Psammothidium pseudoswazii & 0 & 0 & 0 & 0 & 0 & 0 & 0 & 0 & 0 & 0 & 0 & 0 & 0 & 0 & 0 & 0 & 0 & 0 & 0 & 0 & & 2 \\
\hline Psammothidium rossii & 0 & 0 & 0 & 0 & 0 & 0 & 2 & 0 & 0 & 0 & 0 & 0 & 0 & 0 & 0 & 0 & 0 & 0 & 0 & 0 & & 0 \\
\hline
\end{tabular}


Psammothidium subatomoides

Psammothidium ventrale

Pseudo-nitzschia

prolongatoides

Pseudostaurosira brevistriata

Pseudostaurosira parasitica

Rossithidium nodosum

Sellaphora absoluta

Sellaphora pupula

Skabitschewskia oestrupii

Stauroneis anceps

Stauroneis phoenicenteron

Stauroneis producta

Stauroneis schimanskii

Staurosira construens

Staurosirella pinnata

Stephanodiscus medius

Stephanodiscus neostraea

Stephanodiscus niagarae

Stephanodiscus rotula

Surirella amphioxys

Surirella didyma

Surirella splendida

Tabellaria flocculosa

Tryblionella scalaris

Ulnaria ulna 
Table 6-10: Diatom species identified as common ( $>2 \%$ abundance in at least 1 lake) and their relative abundance observed in each lake across the $24-$ lake arsenic gradient from the Cobalt, Ontario region.

\begin{tabular}{|c|c|c|c|c|c|c|c|c|c|c|c|c|c|c|c|c|c|c|c|c|c|c|c|c|}
\hline Taxa & 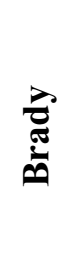 & 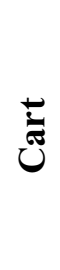 & $\frac{\grave{\circlearrowright}}{\circlearrowright}$ & 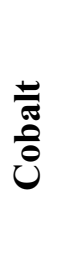 & 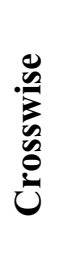 & 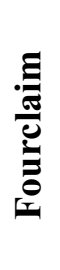 & 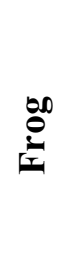 & 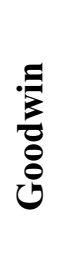 & 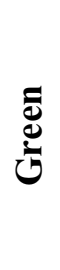 & 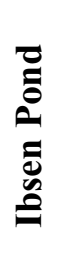 & $\underset{0}{0}$ & 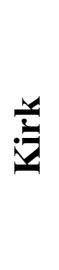 & 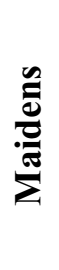 & 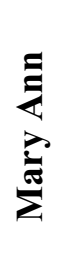 & $\frac{z}{z}$ & $\frac{\bar{e}}{\bar{Z}}$ & 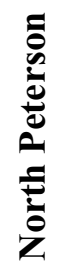 & 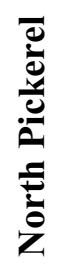 & $\frac{8}{8}$ & $\stackrel{0}{\Xi}$ & $\frac{\grave{d}}{\bar{\Delta}}$ & 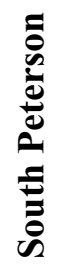 & 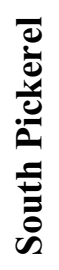 & 둥 \\
\hline Achnanthidium minutissimum & 15 & 11 & 6 & 10 & 7 & 8 & 11 & 3 & 16 & 10 & 4 & 17 & 8 & 24 & 9 & 3 & 43 & 9 & 15 & 33 & 13 & 4 & 4 & 18 \\
\hline Aulocoseira ambigua & 0 & 0 & 0 & 4 & 5 & 0 & 0 & 17 & 1 & 2 & 0 & 4 & 6 & 2 & 0 & 0 & 0 & 0 & 0 & 1 & 0 & 0 & 0 & 0 \\
\hline Aulocoseira distans & 0 & 0 & 0 & 0 & 0 & 0 & 1 & 3 & 0 & 2 & 0 & 0 & 0 & 0 & 5 & 0 & 0 & 0 & 1 & 0 & 0 & 0 & 0 & 0 \\
\hline Brachysira brebissonii & 1 & 2 & 0 & 1 & 0 & 6 & 0 & 0 & 0 & 1 & 1 & 0 & 1 & 1 & 0 & 1 & 1 & 0 & 6 & 2 & 2 & 0 & 0 & 0 \\
\hline Brachysira vitrea & 3 & 12 & 1 & 1 & 0 & 6 & 1 & 0 & 3 & 1 & 0 & 2 & 1 & 1 & 1 & 10 & 4 & 3 & 12 & 6 & 9 & 1 & 1 & 0 \\
\hline Caloneis silicula & 0 & 0 & 0 & 0 & 0 & 0 & 0 & 0 & 1 & 0 & 0 & 0 & 0 & 1 & 0 & 0 & 0 & 0 & 3 & 2 & 0 & 0 & 0 & 0 \\
\hline Denticula kuetzingii & 3 & 14 & 1 & 2 & 1 & 2 & 0 & 0 & 2 & 0 & 0 & 2 & 1 & 1 & 3 & 5 & 0 & 0 & 0 & 2 & 21 & 1 & 17 & 1 \\
\hline Diploneis modica & 0 & 0 & 0 & 2 & 15 & 3 & 1 & 0 & 0 & 0 & 0 & 3 & 0 & 1 & 0 & 0 & 2 & 0 & 0 & 0 & 0 & 1 & 0 & 0 \\
\hline Discotella stelligera & 8 & 0 & 3 & 7 & 4 & 7 & 6 & 12 & 19 & 0 & 0 & 2 & 2 & 1 & 6 & 1 & 0 & 1 & 15 & 1 & 0 & 1 & 7 & 12 \\
\hline Encyonopsis descripta & 3 & 2 & 1 & 1 & 0 & 1 & 0 & 0 & 0 & 0 & 0 & 0 & 1 & 1 & 1 & 6 & 0 & 0 & 2 & 1 & 8 & 1 & 4 & 1 \\
\hline Encyonopsis microcephala & 0 & 1 & 0 & 0 & 0 & 0 & 1 & 0 & 0 & 0 & 0 & 1 & 0 & 0 & 1 & 6 & 0 & 0 & 0 & 2 & 2 & 0 & 0 & 0 \\
\hline Fragilaria capucina & 2 & 12 & 1 & 10 & 2 & 11 & 1 & 3 & 6 & 0 & 11 & 1 & 2 & 2 & 7 & 4 & 16 & 17 & 3 & 1 & 7 & 14 & 3 & 2 \\
\hline Fragilaria exigua & 1 & 1 & 12 & 2 & 0 & 2 & 3 & 1 & 0 & 3 & 13 & 0 & 2 & 2 & 1 & 0 & 1 & 0 & 1 & 1 & 0 & 4 & 0 & 2 \\
\hline Fragilaria tenera & 4 & 0 & 1 & 4 & 1 & 5 & 0 & 1 & 8 & 0 & 1 & 7 & 1 & 0 & 9 & 2 & 0 & 1 & 4 & 0 & 0 & 0 & 1 & 1 \\
\hline Gomphonema gracile & 2 & 4 & 0 & 2 & 1 & 1 & 0 & 0 & 1 & 1 & 0 & 0 & 1 & 0 & 1 & 14 & 1 & 0 & 1 & 1 & 3 & 0 & 0 & 1 \\
\hline Lindavia bodanica & 1 & 0 & 1 & 5 & 2 & 1 & 0 & 5 & 1 & 0 & 0 & 1 & 3 & 0 & 2 & 2 & 0 & 1 & 1 & 2 & 0 & 2 & 2 & 2 \\
\hline Lindavia michiganiana & 8 & 0 & 6 & 18 & 3 & 9 & 5 & 3 & 8 & 1 & 0 & 4 & 2 & 1 & 6 & 5 & 2 & 1 & 3 & 0 & 2 & 2 & 23 & 4 \\
\hline Navicula cryptotonella & 3 & 11 & 0 & 0 & 0 & 3 & 1 & 0 & 1 & 0 & 1 & 1 & 1 & 3 & 1 & 15 & 1 & 0 & 0 & 3 & 8 & 1 & 10 & 0 \\
\hline Navicula libonensis & 1 & 9 & 5 & 2 & 0 & 1 & 0 & 0 & 1 & 0 & 0 & 1 & 0 & 0 & 1 & 5 & 1 & 0 & 0 & 3 & 0 & 1 & 1 & 0 \\
\hline Nitzschia fonticola & 0 & 0 & 0 & 1 & 0 & 3 & 0 & 0 & 1 & 0 & 0 & 0 & 0 & 1 & 1 & 2 & 0 & 0 & 1 & 1 & 2 & 0 & 7 & 0 \\
\hline Pantocsekiella ocellata & 0 & 0 & 10 & 2 & 2 & 0 & 0 & 3 & 0 & 0 & 0 & 4 & 1 & 0 & 0 & 0 & 0 & 0 & 0 & 0 & 0 & 6 & 0 & 3 \\
\hline
\end{tabular}


Psammothidium marginulatum

Psammothidium ventrale

Pseudostaurosira brevistriata

Pseudostaurosira parasitica

Sellaphora pupula

Staurosira construens

Staurosirella pinnata

Tabellaria flocculosa

\begin{tabular}{|ccccccccccccccccccccccccccccccc}
2 & 1 & 0 & 1 & 0 & 3 & 3 & 0 & 0 & 0 & 2 & 3 & 0 & 1 & 0 & 1 & 5 & 43 & 1 & 0 & 1 & 0 & 1 & 5 & \\
1 & 1 & 0 & 0 & 6 & 0 & 1 & 0 & 1 & 2 & 0 & 2 & 2 & 0 & 0 & 0 & 1 & 1 & 2 & 0 & 4 & 8 & 0 & 1 & 0 \\
0 & 0 & 3 & 0 & 0 & 0 & 0 & 1 & 1 & 1 & 5 & 0 & 1 & 3 & 0 & 1 & 0 & 0 & 0 & 2 & 0 & 1 & 0 & 1 & 0 \\
2 & 0 & 3 & 0 & 1 & 0 & 3 & 0 & 1 & 1 & 0 & 1 & 1 & 4 & 1 & 0 & 1 & 0 & 0 & 3 & 2 & 3 & 0 & 3 & \\
6 & 1 & 0 & 1 & 2 & 0 & 0 & 0 & 3 & 4 & 0 & 1 & 1 & 4 & 1 & 0 & 4 & 2 & 1 & 5 & 1 & 2 & 0 & 0 \\
10 & 1 & 8 & 1 & 1 & 11 & 4 & 8 & 4 & 47 & 7 & 7 & 20 & 8 & 3 & 0 & 2 & 1 & 4 & 3 & 1 & 11 & 3 & 5 \\
17 & 1 & 34 & 5 & 3 & 3 & 29 & 18 & 7 & 18 & 45 & 14 & 35 & 21 & 7 & 3 & 5 & 6 & 2 & 14 & 6 & 12 & 0 & 28 \\
0 & 0 & 0 & 0 & 0 & 0 & 3 & 6 & 2 & 0 & 0 & 2 & 2 & 2 & 1 & 0 & 0 & 0 & 19 & 1 & 2 & 0 & 0 & 0 \\
\hline
\end{tabular}

Table 6-11: Identified Cladocera species and their respective count total observed in each lake across the 9-lake (data missing for Kerr Lake) arsenic gradient from the Cobalt, Ontario region.

\begin{tabular}{|c|c|c|c|c|c|c|c|c|c|}
\hline Taxa & 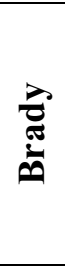 & 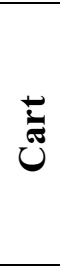 & $\frac{\grave{\Xi}}{\circlearrowright}$ & $\begin{array}{l}\stackrel{\varpi}{\sigma} \\
\stackrel{0}{\theta} \\
ن\end{array}$ & 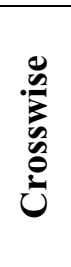 & ฮัญ & 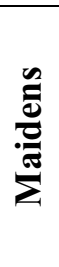 & 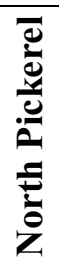 & $\frac{8}{8}$ \\
\hline Acantholeberis curvirostris & 0 & 0 & 0 & 0 & 0 & 0 & 8 & 0 & 0 \\
\hline Acroperus spp. & 2 & 2 & 0 & 0 & 1 & 0 & 0 & 0 & 1 \\
\hline Alona affinis & 0 & 0 & 0 & 0 & 1 & 1 & 2 & 10 & 1 \\
\hline Alona circumfimbriata (rectangula) & 14 & 4 & 1 & 1 & 1 & 16 & 1 & 2 & 7 \\
\hline Alona costata & 0 & 0 & 0 & 0 & 0 & 0 & 1 & 1 & 0 \\
\hline Alona guttata & 22 & 2 & 1 & 2 & 0 & 1 & 1 & 0 & 2 \\
\hline Alona intermedia & 0 & 0 & 1 & 1 & 0 & 1 & 1 & 0 & 0 \\
\hline Alona quadrangularis & 0 & 0 & 0 & 0 & 1 & 1 & 3 & 1 & 0 \\
\hline Alona rustica & 0 & 0 & 0 & 0 & 0 & 0 & 3 & 1 & 0 \\
\hline Alonella excisa & 2 & 8 & 0 & 0 & 0 & 3 & 3 & 5 & 4 \\
\hline Alonella nana & 1 & 3 & 1 & 0 & 1 & 6 & 6 & 7 & 12 \\
\hline Alonella pulchella & 0 & 0 & 0 & 0 & 0 & 0 & 2 & 0 & 0 \\
\hline Bosmina sp. & 31 & 8 & 110 & 77 & 101 & 58 & 62 & 68 & 59 \\
\hline Camptocercus sp. & 3 & 6 & 0 & 0 & 2 & 1 & 0 & 0 & 0 \\
\hline Chydorus brevilabris (sphaericus) & 27 & 71 & 4 & 1 & 2 & 12 & 6 & 13 & 8 \\
\hline
\end{tabular}


D. longispina complex

D. pulex complex

Eurycercus spp.

Graptoleberis testudinaria

Kurzia latissima

Latona parviremis

Latona setifera

Leptodora kindtii

Monospilus dispar

Ophryoxus gracilis

Pleuroxus trigonellus

Pleuroxus truncatus

Pleuroxus unicatus

Sida crystallina americana

\begin{tabular}{|c|c|c|c|c|c|c|c|c|}
\hline 1 & 0 & 0 & 0 & 0 & 1 & 1 & 6 & 1 \\
\hline 0 & 0 & 3 & 1 & 0 & 1 & 0 & 0 & 0 \\
\hline 0 & 0 & 0 & 0 & 1 & 0 & 0 & 0 & 3 \\
\hline 0 & 0 & 1 & 0 & 0 & 0 & 0 & 1 & 0 \\
\hline 0 & 1 & 0 & 0 & 0 & 0 & 0 & 0 & 0 \\
\hline 0 & 1 & 0 & 0 & 0 & 0 & 4 & 0 & 2 \\
\hline 0 & 0 & 0 & 0 & 0 & 2 & 1 & 0 & 1 \\
\hline 0 & 0 & 0 & 0 & 0 & 0 & 1 & 0 & 1 \\
\hline
\end{tabular}

Table 6-12: Cladocera species identified as common ( $>2 \%$ abundance in at least 1 lake) and their relative abundance observed in each lake across the 9-lake (data missing for Kerr Lake) arsenic gradient from the Cobalt, Ontario region.

\begin{tabular}{|c|c|c|c|c|c|c|c|c|c|}
\hline Taxa & 률 & $\overbrace{}^{\sigma}$ & $\frac{\grave{\Xi}}{\circlearrowright}$ & 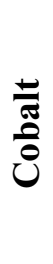 & $\frac{\mathscr{2}}{\mathscr{2}}$ & 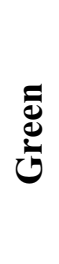 & 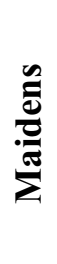 & 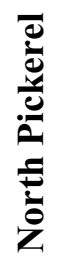 & $\frac{8}{8}$ \\
\hline Acantholeberis curvirostris & 0 & 0 & 0 & 0 & 0 & 0 & 7 & 0 & 0 \\
\hline Acroperus spp. & 2 & 2 & 0 & 0 & 1 & 0 & 0 & 0 & 1 \\
\hline Alona affinis & 0 & 0 & 0 & 0 & 1 & 1 & 2 & 9 & 1 \\
\hline Alona circumfimbriata (rectangula) & 13 & 4 & 1 & 1 & 1 & 15 & 1 & 2 & 7 \\
\hline Alona guttata & 21 & 2 & 1 & 2 & 0 & 1 & 1 & 0 & 2 \\
\hline Alona quadrangularis & 0 & 0 & 0 & 0 & 1 & 1 & 3 & 1 & 0 \\
\hline Alona rustica & 0 & 0 & 0 & 0 & 0 & 0 & 3 & 1 & 0 \\
\hline Alonella excisa & 2 & 7 & 0 & 0 & 0 & 3 & 3 & 4 & 4 \\
\hline
\end{tabular}




\begin{tabular}{|c|c|c|c|c|c|c|c|c|c|}
\hline Alonella nana & 1 & 3 & 1 & 0 & 1 & 6 & 5 & 6 & 11 \\
\hline Alonella pulchella & 0 & 0 & 0 & 0 & 0 & 0 & 2 & 0 & 0 \\
\hline Bosmina sp. & 30 & 7 & 89 & 69 & 89 & 55 & 55 & 59 & 56 \\
\hline Camptocercus sp. & 3 & 6 & 0 & 0 & 2 & 1 & 0 & 0 & 0 \\
\hline Chydorus brevilabris (sphaericus) & 26 & 66 & 3 & 1 & 2 & 11 & 5 & 11 & 8 \\
\hline D. longispina complex & 0 & 0 & 1 & 0 & 0 & 0 & 2 & 0 & 0 \\
\hline D. pulex complex & 0 & 0 & 0 & 23 & 2 & 0 & 3 & 0 & 0 \\
\hline Eurycercus spp. & 1 & 0 & 0 & 0 & 0 & 1 & 1 & 5 & 1 \\
\hline Kurzia latissima & 0 & 0 & 2 & 1 & 0 & 1 & 0 & 0 & 0 \\
\hline Latona parviremis & 0 & 0 & 0 & 0 & 1 & 0 & 0 & 0 & 3 \\
\hline Ophryoxus gracilis & 0 & 1 & 0 & 0 & 0 & 0 & 4 & 0 & 2 \\
\hline Pleuroxus trigonellus & 0 & 0 & 0 & 0 & 0 & 2 & 1 & 0 & 1 \\
\hline Sida crystallina americana & 2 & 2 & 0 & 2 & 0 & 1 & 1 & 0 & 1 \\
\hline
\end{tabular}

Table 6-13: Identified Chironomid species and their respective count totals observed in each lake across the 10-lake arsenic gradient from the Cobalt, Ontario region.

\begin{tabular}{|c|c|c|c|c|c|c|c|c|c|c|}
\hline Taxa & 莡 & $\underbrace{\pi}$ & $\frac{\ddot{\Xi}}{\circlearrowright}$ & $\frac{\varpi}{\tilde{\sigma}}$ & 苋 & 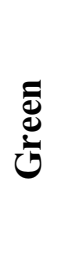 & $\stackrel{0}{\square}$ & 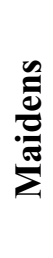 & 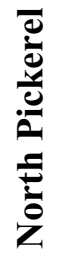 & $\frac{3}{0}$ \\
\hline Acamptocaldius & 0 & 0 & 0 & 0 & 0 & 0 & 0 & 0 & 4 & 0 \\
\hline Chaetocladius & 2 & 0 & 0 & 0 & 2 & 0 & 0 & 2 & 0 & 2 \\
\hline Chironomus anthracinus-type & 8 & 10 & 2 & 0 & 8 & 14 & 8 & 2 & 0 & 8 \\
\hline Chironomus plumosus-type & 0 & 2 & 0 & 0 & 0 & 6 & 0 & 4 & 0 & 0 \\
\hline Cladopelma laccophila-type & 0 & 0 & 0 & 0 & 0 & 2 & 0 & 0 & 0 & 0 \\
\hline Cladopelma lateralis & 0 & 0 & 0 & 1 & 12 & 4 & 0 & 6 & 0 & 0 \\
\hline Cladotanytarsus mancus & 4 & 0 & 0 & 2 & 0 & 2 & 2 & 0 & 2 & 2 \\
\hline Corynocera oliveri-type & 0 & 0 & 0 & 0 & 4 & 0 & 0 & 0 & 0 & 0 \\
\hline Corynoneura coronata-type & 0 & 2 & 0 & 0 & 0 & 0 & 0 & 0 & 12 & 2 \\
\hline
\end{tabular}


Corynoneura type A

Cricotopus othrocaldius

Cricotopus type P

Cryptochironomis

Diamesa

Dicrotendipes nervosus-type

Einfeldia dissidens-type

Einfeldia natchitocheae-type

Einfeldia pagana-type

Endochironomus albipennis-type

Eukiefferiella devonica-type

Glyptotendipes barbipes-type

Glyptotendipes pallens-type

Glyptotendipes severini-type

Hydrobaenus

Lipiniella

Microchironomus

Microspectra contracta-type

Microspectra insignilobus-type

Microspectra radialis-type

Microspectra type-A

Microspsectra pallidula-type

Microtendipes pedullus-type

Omisus

Orthocladius oliveri-type

Orthocladius type-I

Parachironomus vitiosus-type

Parakiefferiella bathophila-type

Parakiefferiella nigra-type

Parametriocnemus - Paraphaenocladius

Paratanytarsus

Paratanytarsus austriacus-type

Paratanytarsus penicillatus-type

Phaenospectra

\begin{tabular}{|c|c|c|c|}
\hline 0 & 0 & 2 & 0 \\
\hline 2 & 0 & 0 & 2 \\
\hline 2 & 2 & 0 & 0 \\
\hline 2 & 0 & 0 & 0 \\
\hline 0 & 0 & 0 & 0 \\
\hline 0 & 8 & 0 & 0 \\
\hline 4 & 0 & 0 & 2 \\
\hline 0 & 0 & 0 & 0 \\
\hline 4 & 12 & 6 & 0 \\
\hline 2 & 0 & 6 & 0 \\
\hline 0 & 0 & 0 & 0 \\
\hline 0 & 0 & 0 & 0 \\
\hline 4 & 0 & 2 & 0 \\
\hline 0 & 2 & 0 & 0 \\
\hline 0 & 0 & 0 & 0 \\
\hline 0 & 0 & 0 & 0 \\
\hline 2 & 0 & 0 & 0 \\
\hline 0 & 0 & 0 & 0 \\
\hline 0 & 2 & 0 & 0 \\
\hline 0 & 6 & 0 & 0 \\
\hline 0 & 0 & 0 & 0 \\
\hline 0 & 0 & 0 & 0 \\
\hline 0 & 0 & 0 & 0 \\
\hline 0 & 0 & 0 & 0 \\
\hline 2 & 0 & 0 & 0 \\
\hline 0 & 2 & 2 & 0 \\
\hline 0 & 0 & 0 & 0 \\
\hline 0 & 6 & 0 & 0 \\
\hline 0 & 2 & 0 & 0 \\
\hline 2 & 0 & 0 & 0 \\
\hline 0 & 0 & 0 & 0 \\
\hline 2 & 0 & 0 & 0 \\
\hline 0 & 0 & 0 & 0 \\
\hline 0 & 0 & 0 & 0 \\
\hline
\end{tabular}

\begin{tabular}{|c|c|c|c|c|}
\hline 0 & 0 & 0 & 0 & 0 \\
\hline 6 & 2 & 0 & 0 & 2 \\
\hline 0 & 0 & 0 & 0 & 0 \\
\hline 2 & 0 & 0 & 0 & 4 \\
\hline 0 & 0 & 0 & 0 & 0 \\
\hline 0 & 0 & 4 & 0 & 6 \\
\hline 0 & 4 & 0 & 0 & 0 \\
\hline 0 & 2 & 0 & 0 & 0 \\
\hline 2 & 10 & 6 & 3 & 2 \\
\hline 0 & 4 & 10 & 6 & 0 \\
\hline 2 & 0 & 0 & 0 & 2 \\
\hline 0 & 1 & 0 & 0 & 2 \\
\hline 0 & 0 & 0 & 2 & 0 \\
\hline 0 & 0 & 0 & 0 & 0 \\
\hline 0 & 2 & 0 & 0 & 2 \\
\hline 2 & 0 & 0 & 0 & 0 \\
\hline 2 & 2 & 0 & 2 & 0 \\
\hline 0 & 2 & 6 & 0 & 0 \\
\hline 0 & 0 & 0 & 0 & 0 \\
\hline 0 & 4 & 0 & 0 & 2 \\
\hline 0 & 0 & 0 & 0 & 0 \\
\hline 2 & 0 & 4 & 0 & 4 \\
\hline 2 & 4 & 0 & 0 & 2 \\
\hline 0 & 0 & 0 & 0 & 2 \\
\hline 0 & 0 & 0 & 0 & 1 \\
\hline 0 & 0 & 0 & 2 & 2 \\
\hline 2 & 0 & 0 & 0 & 0 \\
\hline 0 & 0 & 0 & 0 & 0 \\
\hline 0 & 0 & 0 & 2 & 0 \\
\hline 0 & 0 & 0 & 0 & 0 \\
\hline 6 & 0 & 0 & 6 & 0 \\
\hline 0 & 0 & 0 & 0 & 6 \\
\hline 0 & 2 & 2 & 0 & 0 \\
\hline 0 & 0 & 0 & 0 & 0 \\
\hline
\end{tabular}


Polypedilum convictum-type

Polypedilum nubeculosum-type

Polypedilum type- $A$

Polypediulum sodens-type

Psectrocladius

Pseudochironomus

Pseudorthocladius

Smittia

Stempellina

Stictochironomus

Symposiocladius

Tanypodinae

Tanytarsus chinyensis-type 1

Tanytarsus glabrescens-type

Tanytarsus lactescens-type

Tanytarsus lugens-type

Tanytarsus pallidicornis-type

Trissocladius

Unknown

Xenochironomus

Table 6-14: Chironomid species identified as common ( $>5 \%$ abundance in at least 1 lake) and their relative abundance observed in each lake across the 10-lake arsenic gradient from the Cobalt, Ontario region.

\begin{tabular}{|c|c|c|c|c|c|c|c|c|c|c|}
\hline Taxa & 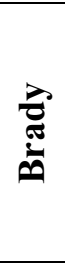 & $\underset{U}{\widetilde{U}}$ & $\frac{\grave{\circlearrowright}}{\circlearrowright}$ & $\frac{\sqrt{\tilde{\sigma}}}{\stackrel{0}{0}}$ & $\underbrace{\infty}_{0}$ & 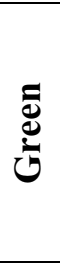 & $\ddot{0}$ & 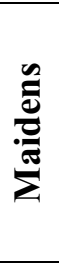 & 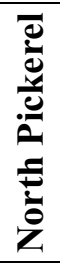 & $\frac{3}{0}$ \\
\hline Chironomus anthracinus-type & 11 & 13 & 6 & 0 & 9 & 14 & 12 & 2 & 0 & 8 \\
\hline Chironomus plumosus-type & 0 & 3 & 0 & 0 & 0 & 6 & 0 & 5 & 0 & 0 \\
\hline Cladopelma lateralis & 0 & 0 & 0 & 6 & 13 & 4 & 0 & 7 & 0 & 0 \\
\hline Cladotanytarsus mancus & 6 & 0 & 0 & 12 & 0 & 2 & 3 & 0 & 2 & 2 \\
\hline Corynoneura coronata-type & 0 & 3 & 0 & 0 & 0 & 0 & 0 & 0 & 12 & 2 \\
\hline
\end{tabular}


Corynoneura type $A$

Cricotopus othrocaldius

Cryptochironomis

Dicrotendipes nervosus-type

Einfeldia dissidens-type

Einfeldia pagana-type

Endochironomus albipennis-type

Glyptotendipes pallens-type

Microspectra contracta-type

Microspectra radialis-type

Microspsectra pallidula-type

Microtendipes pedullus-type

Orthocladius type-I

Parakiefferiella bathophila-type

Paratanytarsus

Paratanytarsus austriacus-type

Polypedilum nubeculosum-type

Pseudochironomus

Tanypodinae

Tanytarsus lactescens-type

Tanytarsus lugens-type

Unknown 
Table 6-15: Identified open water zooplankton families and their averaged count totals observed in each lake across the 10-lake arsenic gradient from the Cobalt, Ontario region.

\begin{tabular}{|c|c|c|c|c|c|c|c|c|c|c|}
\hline Taxa & 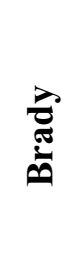 & تَّ & $\frac{\grave{\Xi}}{\bar{U}}$ & $\begin{array}{l}\frac{\hbar}{\pi} \\
\frac{0}{0}\end{array}$ & 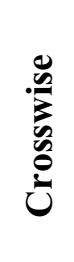 & ङँّ & $\stackrel{\Xi}{\square}$ & 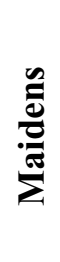 & 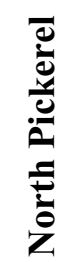 & $\frac{0}{0}$ \\
\hline Chaoboridae & 0 & 1 & 0 & 0 & 0 & 0 & 0 & 0 & 0 & 0 \\
\hline Cladocera Bosminidae & 9 & 1 & 171 & 125 & 33 & 42 & 0 & 21 & 135 & 21 \\
\hline Cladocera Chydoridae & 0 & 0 & 0 & 0 & 0 & 0 & 0 & 0 & 0 & 0 \\
\hline Cladocera Daphniidae & 0 & 0 & 1 & 0 & 1 & 0 & 0 & 0 & 29 & 0 \\
\hline Cladocera Holopedidae & 1 & 2 & 80 & 0 & 1 & 5 & 0 & 1 & 14 & 0 \\
\hline Cladocera Leptodoridae & 0 & 0 & 0 & 0 & 1 & 0 & 0 & 0 & 0 & 0 \\
\hline Cladocera Macrothricidae & 0 & 0 & 0 & 0 & 1 & 0 & 0 & 0 & 1 & 0 \\
\hline Cladocera Sididae & 1 & 0 & 134 & 0 & 27 & 17 & 0 & 0 & 55 & 0 \\
\hline Copepoda Calanoida [order] & 18 & 10 & 557 & 40 & 674 & 145 & 9 & 6 & 72 & 12 \\
\hline Copepoda Cyclopidae & 3 & 0 & 179 & 43 & 163 & 20 & 0 & 16 & 736 & 36 \\
\hline Copepoda Ergasilidae & 3 & 0 & 21 & 23 & 41 & 2 & 0 & 4 & 68 & 0 \\
\hline Copepoda Harpacticoida & 0 & 0 & 0 & 1 & 3 & 0 & 0 & 0 & 5 & 0 \\
\hline Copepoda Temoridae & 0 & 0 & 0 & 14 & 2 & 0 & 0 & 0 & 0 & 0 \\
\hline Crustacea Chirocephelidae & 0 & 0 & 0 & 0 & 0 & 0 & 0 & 0 & 0 & 0 \\
\hline Crustacea Mysidae & 0 & 2 & 0 & 0 & 0 & 0 & 0 & 0 & 0 & 0 \\
\hline Crustacea Ostracoda & 0 & 0 & 0 & 2 & 0 & 0 & 208 & 0 & 20 & 0 \\
\hline Hexapoda Chaoboridae & 0 & 0 & 0 & 0 & 0 & 0 & 0 & 0 & 0 & 0 \\
\hline Hydracarina & 145 & 6 & 103 & 0 & 205 & 149 & 22 & 15 & 843 & 168 \\
\hline Rotifera Asplanchnidae & 0 & 0 & 0 & 0 & 0 & 0 & 0 & 0 & 0 & 0 \\
\hline Rotifera Brachionidae & 886 & 9 & 1623 & 5 & 47 & 1 & 155 & 10 & 8402 & 1 \\
\hline
\end{tabular}


Table 6-16: Open water zooplankton families identified as common ( $>2 \%$ abundance in at least 1 lake) and their relative abundance observed in each lake across the 10-lake arsenic gradient from the Cobalt, Ontario region.

\begin{tabular}{|c|c|c|c|c|c|c|c|c|c|c|}
\hline Taxa & 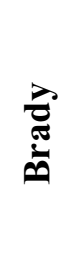 & 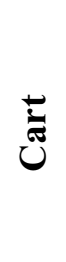 & $\frac{\grave{\Xi}}{\circlearrowright}$ & $\begin{array}{l}\frac{\pi}{\tilde{\sigma}} \\
\frac{0}{0}\end{array}$ & 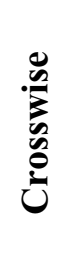 & एँّ & 豙 & $\frac{\mathscr{E}}{\stackrel{\Xi}{\tilde{E}}}$ & 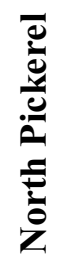 & $\frac{\partial}{\partial}$ \\
\hline Cladocera Bosminidae & 1 & 4 & 6 & 53 & 3 & 11 & 0 & 29 & 1 & 9 \\
\hline Cladocera Holopedidae & 0 & 6 & 3 & 0 & 0 & 1 & 0 & 1 & 0 & 0 \\
\hline Cladocera Sididae & 0 & 0 & 5 & 0 & 2 & 4 & 0 & 0 & 1 & 0 \\
\hline Copepoda Calanoida [order] & 2 & 32 & 19 & 17 & 57 & 38 & 2 & 8 & 1 & 5 \\
\hline Copepoda Cyclopidae & 0 & 0 & 6 & 18 & 14 & 5 & 0 & 22 & 6 & 15 \\
\hline Copepoda Ergasilidae & 0 & 7 & 1 & 10 & 3 & 1 & 0 & 6 & 0 & 0 \\
\hline Crustacea Ostracoda & 0 & 1 & 0 & 1 & 0 & 0 & 53 & 0 & 0 & 0 \\
\hline Hydracarina & 14 & 20 & 4 & 0 & 17 & 39 & 6 & 20 & 8 & 71 \\
\hline Rotifera Brachionidae & 83 & 29 & 57 & 2 & 4 & 0 & 39 & 13 & 82 & 0 \\
\hline
\end{tabular}




\section{SUPPLEMENTARY SURFACE WATER ORDINATION DATA}

Table 6-17: De-trended correspondence analysis (DCA) results for the 24-lake gradient and diatom species data.

\begin{tabular}{c|ccr}
\hline & DCA1 & DCA2 & DCA3 \\
\hline Eigenvalues & 0.2106 & 0.1256 & 0.08794 \\
Decorana Values & 0.2107 & 0.1151 & 0.05660 \\
Axis Lengths & 1.8815 & 1.7557 & 0.02735 \\
\hline
\end{tabular}

Table 6-18: Principal component analysis (PCA) results for the 24-lake gradient and diatom species data. Only the first 8 components shown of the 23 computed.

\begin{tabular}{|c|c|c|c|c|c|c|c|c|}
\hline & PCA1 & PCA2 & PCA3 & PCA4 & PCA5 & PCA6 & PCA7 & PCA8 \\
\hline Eigenvalues & 6.8607 & 4.1992 & 3.2963 & 3.07896 & 2.4065 & 1.8943 & 1.54938 & 1.40780 \\
\hline Proportion Explained & 0.2144 & 0.1312 & 0.1030 & 0.09622 & 0.0752 & 0.0592 & 0.04842 & 0.04399 \\
\hline Cumulative Proportion & 0.2144 & 0.3456 & 0.4486 & 0.54485 & 0.6201 & 0.6792 & 0.72767 & 0.77166 \\
\hline
\end{tabular}

Table 6-19: Site scores for the 24-lake gradient and diatom PCA data.

\begin{tabular}{|c|c|c|c|c|c|c|}
\hline Lakes & PC1 & PC2 & PC3 & PC4 & PC5 & PC6 \\
\hline Pine & -0.46659 & -1.49002 & -1.44316 & -0.28422 & -0.73047 & -0.583809 \\
\hline Frog & 0.88979 & -0.21277 & -0.09969 & 0.25776 & -0.03131 & -0.728026 \\
\hline Nicol & -2.43655 & -0.09537 & 0.69475 & -0.75486 & -1.68915 & 1.485628 \\
\hline Oxbow & -0.51934 & 0.43518 & -3.00469 & -0.75758 & 1.58186 & 0.134143 \\
\hline Mary Ann & 0.52782 & -1.50279 & -0.98569 & -0.04965 & 0.1015 & -1.187949 \\
\hline Goodwin & 1.48087 & 1.294 & -0.83289 & -1.61296 & -0.02361 & 1.35749 \\
\hline Clear & 1.20598 & -0.35966 & 1.03822 & -1.24211 & -1.68973 & 0.022193 \\
\hline Green & -0.24969 & 0.82824 & -1.20525 & -0.39694 & 0.47764 & -0.508317 \\
\hline South Pickerel & -1.43087 & 1.47558 & 1.82992 & -1.57784 & 0.80052 & -2.24072 \\
\hline North Pickerel & 0.02117 & -0.61793 & 1.32608 & 1.22958 & 2.85142 & 0.125003 \\
\hline
\end{tabular}




\begin{tabular}{|c|c|c|c|c|c|c|}
\hline Silver & -1.80396 & -0.79349 & -0.22204 & 0.5984 & -1.11278 & -1.012297 \\
\hline Maidens & 0.90562 & -0.08662 & -0.16232 & -0.56684 & -0.78907 & 0.244927 \\
\hline Kirk & 0.63236 & 1.21554 & -0.23923 & 1.66198 & -0.92916 & 0.024773 \\
\hline New & -0.13684 & 1.09283 & -0.27303 & -0.54961 & 0.07433 & 0.572541 \\
\hline Crosswise & 0.90685 & 1.61033 & 0.17775 & 2.58835 & -0.8361 & 0.242732 \\
\hline Brady & -0.40125 & 0.01828 & -0.38388 & 0.23501 & -0.3205 & -0.967514 \\
\hline Ibsen Pond & 1.26513 & -1.14463 & -0.75197 & -0.09846 & -0.64886 & -0.002242 \\
\hline South Peterson & 0.87592 & -0.56066 & 1.19679 & 0.43877 & -0.36815 & -0.114497 \\
\hline North Peterson & -0.19111 & -0.90479 & -0.10251 & 1.98816 & 1.2036 & 0.085429 \\
\hline Kerr & 1.04682 & -1.92805 & 1.52279 & -1.16909 & 1.04497 & 1.859692 \\
\hline Cobalt & -0.12549 & 1.96268 & 0.52882 & 0.37424 & -0.01125 & 1.308183 \\
\hline Fourclaim & -0.93968 & 0.48321 & 0.01219 & -0.57538 & 1.52728 & 1.069106 \\
\hline Tooth & 0.78366 & 0.33 & 1.06286 & -0.57772 & 0.14295 & -2.330883 \\
\hline Cart & -1.84061 & -1.04908 & 0.31617 & 0.84101 & -0.62591 & 1.144414 \\
\hline
\end{tabular}

Table 6-20: Redundancy analysis (RDA) biplot scores for the 24-lake gradient and diatom species data.

\begin{tabular}{c|cccccc}
\hline & RDA1 & RDA2 & RDA3 & RDA4 & RDA5 & RDA6 \\
\hline Arsenic & 0.16145 & -0.071076 & 0.333973 & -0.36674 & 0.066319 & -0.23890 \\
pH & 0.42325 & -0.155864 & 0.568809 & -0.24180 & -0.241629 & 0.21424 \\
Chloride & -0.31174 & 0.154403 & 0.288096 & -0.19528 & -0.202380 & -0.34337 \\
Sulphate & -0.30749 & 0.005174 & 0.525287 & -0.33131 & 0.231827 & -0.33165 \\
Sodium & -0.39714 & -0.326653 & -0.001947 & -0.32213 & -0.118717 & -0.29129 \\
Potassium & 0.11458 & -0.202162 & 0.224529 & -0.53810 & -0.280818 & -0.45467 \\
Aluminum & 0.39953 & 0.017497 & -0.455912 & 0.35324 & -0.010107 & 0.27737 \\
Cadmium & 0.01096 & -0.108619 & 0.355745 & -0.09941 & -0.382672 & 0.37046 \\
Chromium & -0.10706 & -0.005286 & 0.095184 & -0.01482 & -0.023968 & 0.27088 \\
Cobalt & -0.16729 & -0.259781 & 0.407436 & -0.32669 & 0.005301 & 0.30679 \\
Copper & 0.29695 & -0.012175 & 0.203834 & -0.68215 & 0.004966 & 0.21095 \\
Iron & 0.12387 & -0.162746 & -0.622677 & -0.13599 & 0.133292 & 0.07687 \\
Lead & 0.55973 & -0.006365 & -0.089325 & 0.09216 & 0.040135 & 0.24335 \\
Zinc & -0.10752 & -0.180187 & -0.033770 & 0.08685 & -0.225336 & 0.20349
\end{tabular}


Table 6-21: De-trended correspondence analysis (DCA) results for the 9-lake gradient and cladocera species data.

\begin{tabular}{c|cccc}
\hline & DCA1 & DCA2 & DCA3 & DCA4 \\
\hline Eigenvalues & 0.2324 & 0.2082 & 0.04562 & 0.117916 \\
Decorana Values & 0.2465 & 0.1960 & 0.01639 & 0.002733 \\
Axis Lengths & 1.5189 & 1.7321 & 0.67345 & 1.225217 \\
\hline
\end{tabular}

Table 6-22: Principal component analysis (PCA) results for the 9-lake gradient and cladocera species data.

\begin{tabular}{c|cccccccc}
\hline & PCA1 & PCA2 & PCA3 & PCA4 & PCA5 & PCA6 & PCA7 & PCA8 \\
\hline Eigenvalues & 6.3284 & 5.2674 & 3.0554 & 1.82340 & 1.74791 & 1.11359 & 0.86284 & 0.80099 \\
Proportion Explained & 0.3014 & 0.2508 & 0.1455 & 0.08683 & 0.08323 & 0.05303 & 0.04109 & 0.03814 \\
Cumulative Proportion & 0.3014 & 0.5522 & 0.6977 & 0.78451 & 0.86774 & 0.92077 & 0.96186 & 1.00000 \\
\hline
\end{tabular}

Table 6-23: Site scores for the 9-lake gradient and cladocera PCA data.

\begin{tabular}{|c|c|c|c|c|c|c|}
\hline Lakes & PC1 & PC2 & PC3 & PC4 & PC5 & PC6 \\
\hline Oxbow & -0.13745 & -0.9565 & 1.1462 & -1.572878 & 2.2272 & -0.28401 \\
\hline Clear & 0.17969 & 1.8026 & -0.1128 & -0.291581 & -0.4199 & 2.46338 \\
\hline Green & -0.05594 & -0.3741 & 0.8999 & -1.979718 & -1.4712 & 0.405 \\
\hline North Pickerel & 0.9898 & -0.3915 & 2.021 & 1.622043 & -1.3761 & -0.77789 \\
\hline Maidens & 2.55814 & -1.1114 & -1.8657 & 0.017791 & 0.1802 & 0.03001 \\
\hline Crosswise & -0.01532 & 1.0887 & 0.7178 & 1.428966 & 1.7267 & 0.02389 \\
\hline Brady & -1.64793 & -0.684 & -0.6633 & 0.001706 & -0.8454 & -0.83689 \\
\hline Cobalt & -0.25832 & 1.9592 & -1.1354 & -0.482263 & -0.1484 & -2.06381 \\
\hline Cart & -1.61268 & -1.3331 & -1.0077 & 1.255935 & 0.1269 & 1.04032 \\
\hline
\end{tabular}


Table 6-24: Redundancy analysis (RDA) biplot scores for the 9-lake gradient and cladocera species data.

\begin{tabular}{|c|c|c|c|c|c|c|}
\hline & RDA1 & RDA2 & RDA3 & RDA4 & RDA5 & RDA6 \\
\hline Arsenic & 0.44624 & -0.01259 & -0.75569 & -0.2831 & 0.13047 & 0.29599 \\
\hline Calcium & 0.51403 & 0.47976 & -0.15054 & -0.6069 & -0.04879 & 0.31513 \\
\hline Cobalt & -0.09813 & -0.04684 & 0.19748 & -0.7583 & -0.02639 & 0.2432 \\
\hline Iron & 0.31064 & -0.67075 & -0.06128 & 0.228 & -0.20217 & -0.16282 \\
\hline Lead & 0.45219 & -0.31523 & -0.07796 & -0.4438 & 0.19789 & 0.05642 \\
\hline pH & 0.17253 & -0.41276 & 0.19188 & -0.2155 & 0.83424 & 0.10545 \\
\hline Water Depth & 0.08103 & 0.60645 & 0.11728 & 0.2421 & 0.02445 & -0.54954 \\
\hline
\end{tabular}

Table 6-25: De-trended correspondence analysis (DCA) results for the 10-lake gradient and chironomid species data.

\begin{tabular}{c|ccc}
\hline & DCA1 & DCA2 & DCA3 \\
\hline Eigenvalues & 0.2787 & 0.1781 & 0.09263 \\
Decorana Values & 0.2912 & 0.1145 & 0.097365 \\
Axis Lengths & 2.1308 & 1.6502 & 0.006438 \\
\hline
\end{tabular}

Table 6-26: Principal component analysis (PCA) results for the 10-lake gradient and chironomid species data. Only the first 8 components shown of the 9 computed.

\begin{tabular}{|c|c|c|c|c|c|c|c|c|}
\hline & PCA1 & PCA2 & PCA3 & PCA4 & PCA5 & PCA6 & PCA 7 & PCA8 \\
\hline Eigenvalues & 5.4827 & 4.7624 & 3.9828 & 3.6689 & 3.0955 & 2.03648 & 1.75270 & 1.23483 \\
\hline Proportion Explained & 0.2031 & 0.1764 & 0.1475 & 0.1359 & 0.1146 & 0.07543 & 0.06491 & 0.04573 \\
\hline Cumulative Proportion & 0.2031 & 0.3795 & 0.5270 & 0.6628 & 0.7775 & 0.85292 & 0.91783 & 0.96357 \\
\hline
\end{tabular}

Table 6-27: Site scores for the 10-lake gradient and chironomid PCA data.

\begin{tabular}{c|cccrrr}
\hline Lakes & PC1 & PC2 & PC3 & PC4 & PC6 & \\
\hline Oxbow & -0.04913 & 0.1792 & -0.1941 & 0.1926 & -0.23249 \\
Clear & 1.2027 & -1.6001 & 2.5282 & -0.1989 & 0.99983
\end{tabular}




\begin{tabular}{|c|c|c|c|c|c|c|}
\hline Green & 0.22135 & -0.61 & -1.3078 & -0.1048 & -1.75795 & 0.2735 \\
\hline North Pickerel & -0.42439 & 2.2911 & 0.4504 & 1.8492 & 1.55112 & 0.866 \\
\hline Maidens & -0.3214 & -2.275 & -0.8754 & 0.5149 & 1.01509 & 0.7148 \\
\hline Crosswise & -1.21363 & -0.3106 & -1.84 & 0.1685 & 0.92526 & -0.4896 \\
\hline Brady & -0.76467 & 0.4933 & 0.2908 & -1.567 & 0.95653 & -2.7515 \\
\hline Kerr & 1.25321 & 1.2925 & -0.4147 & -2.5884 & -0.07335 & 1.4234 \\
\hline Cobalt & -2.20751 & 0.1226 & 1.6583 & 0.1157 & -2.19487 & 0.1471 \\
\hline Cart & 2.30346 & 0.417 & -0.2957 & 1.6183 & -1.18917 & -1.6667 \\
\hline
\end{tabular}

Table 6-28: Redundancy analysis (RDA) biplot scores for the 10-lake gradient and chironomid species data.

\begin{tabular}{c|cccccc}
\hline & RDA1 & RDA2 & RDA3 & RDA4 & RDA5 & RDA6 \\
\hline Arsenic & -0.13017 & 0.09939 & -0.1629 & -0.38779 & -0.6492 & 0.61222 \\
Calcium & -0.03664 & 0.3778 & -0.6569 & -0.41705 & -0.2254 & 0.32263 \\
Cobalt & -0.46031 & 0.10525 & -0.6105 & -0.30649 & 0.1143 & 0.41008 \\
Iron & -0.44758 & -0.15114 & 0.6652 & -0.35493 & -0.2516 & -0.33439 \\
Lead & -0.2002 & 0.44789 & -0.2107 & 0.3984 & -0.6638 & -0.30972 \\
pH & -0.5853 & 0.59933 & -0.1746 & 0.21725 & -0.0398 & 0.24189 \\
Water Depth & 0.26589 & -0.34118 & -0.842 & 0.04169 & 0.2789 & -0.03661 \\
\hline
\end{tabular}

Table 6-29: De-trended correspondence analysis (DCA) results for the 10-lake gradient and zooplankton species data.

\begin{tabular}{c|cccc}
\hline & DCA1 & DCA2 & DCA3 & DCA4 \\
\hline Eigenvalues & 0.3216 & 0.10026 & 0.08543 & 0.0854309 \\
Decorana Values & 0.3718 & 0.05904 & 0.00250 & 0.002723 \\
Axis Lengths & 1.9976 & 1.09746 & 0.94996 & 0.9499555 \\
\hline
\end{tabular}


Table 6-30: Principal component analysis (PCA) results for the 10-lake gradient and zooplankton species data. Only the first 8 components shown of the 9 computed.

\begin{tabular}{c|cccccccc}
\hline & PCA1 & PCA2 & PCA3 & PCA4 & PCA5 & PCA6 & PCA7 & PCA8 \\
\hline Eigenvalues & 3.2635 & 1.7431 & 1.5883 & 1.0561 & 0.84498 & 0.33373 & 0.15456 & 0.11564 \\
Proportion Explained & 0.3626 & 0.1937 & 0.1765 & 0.1173 & 0.09389 & 0.03708 & 0.01717 & 0.001285 \\
Cumulative Proportion & 0.3626 & 0.5563 & 0.7328 & 0.8501 & 0.94399 & 0.98107 & 0.99824 & 0.999525 \\
\hline
\end{tabular}

Table 6-31: Site scores for the 10-lake gradient and zooplankton PCA data.

\begin{tabular}{|c|c|c|c|c|c|c|}
\hline Lake & PC1 & PC2 & PC3 & PC4 & PC5 & PC6 \\
\hline Oxbow & -0.17735 & 0.9130 & -1.9450 & 0.8241 & 0.5386 & 0.45689 \\
\hline Clear & -0.06503 & -1.3987 & 0.5123 & -1.2908 & 0.0791 & 1.32860 \\
\hline Green & -0.76945 & -1.0242 & -0.9788 & 0.3231 & -0.7559 & 0.57535 \\
\hline North Pickerel & 0.93305 & 0.1088 & -0.2963 & -1.4900 & 0.5427 & -0.03627 \\
\hline Maidens & -0.86933 & 0.8182 & 0.2883 & 0.1401 & 1.0894 & 0.83802 \\
\hline Crosswise & -0.75526 & -0.4830 & -0.5421 & -0.3516 & -1.3551 & -1.71879 \\
\hline Brady & 1.26524 & 0.1381 & -0.1223 & -0.3272 & 1.0263 & -1.40759 \\
\hline Kerr & 1.76953 & 0.5875 & 0.5618 & 0.9237 & -1.6072 & 0.81159 \\
\hline Cobalt & -1.19350 & 1.5530 & 1.3629 & -0.4820 & -0.5141 & -0.28634 \\
\hline Cart & -0.13789 & -1.2126 & 1.1592 & 1.7304 & 0.9562 & -0.56145 \\
\hline
\end{tabular}

Table 6-32: Redundancy analysis (RDA) biplot scores for the 10-lake gradient and zooplankton species data.

\begin{tabular}{c|cccccc}
\hline & RDA1 & RDA2 & RDA3 & \multirow{2}{*}{ RDA4 } & RDA5 & RDA6 \\
\hline Arsenic & 0.08971 & 0.6276 & 0.6352 & 0.3191 & -0.3042 & 0.0011210 \\
Calcium & 0.47553 & 0.7130 & 0.3133 & 0.2049 & 0.3417 & -0.0325688 \\
Cobalt & 0.58773 & 0.4731 & 0.4405 & -0.2844 & 0.2654 & 0.1590788 \\
Iron & -0.37852 & -0.6027 & 0.5146 & 0.1844 & -0.1826 & -0.2284637 \\
Lead & 0.48667 & -0.1360 & -0.2084 & 0.7032 & -0.4265 & 0.0008695
\end{tabular}




\begin{tabular}{c|cccccc} 
pH & 0.51585 & 0.1848 & 0.1199 & -0.1998 & -0.4517 & -0.6352835 \\
Water Depth & 0.52399 & 0.2130 & 0.1371 & -0.3768 & 0.4478 & 0.0920513 \\
\hline
\end{tabular}

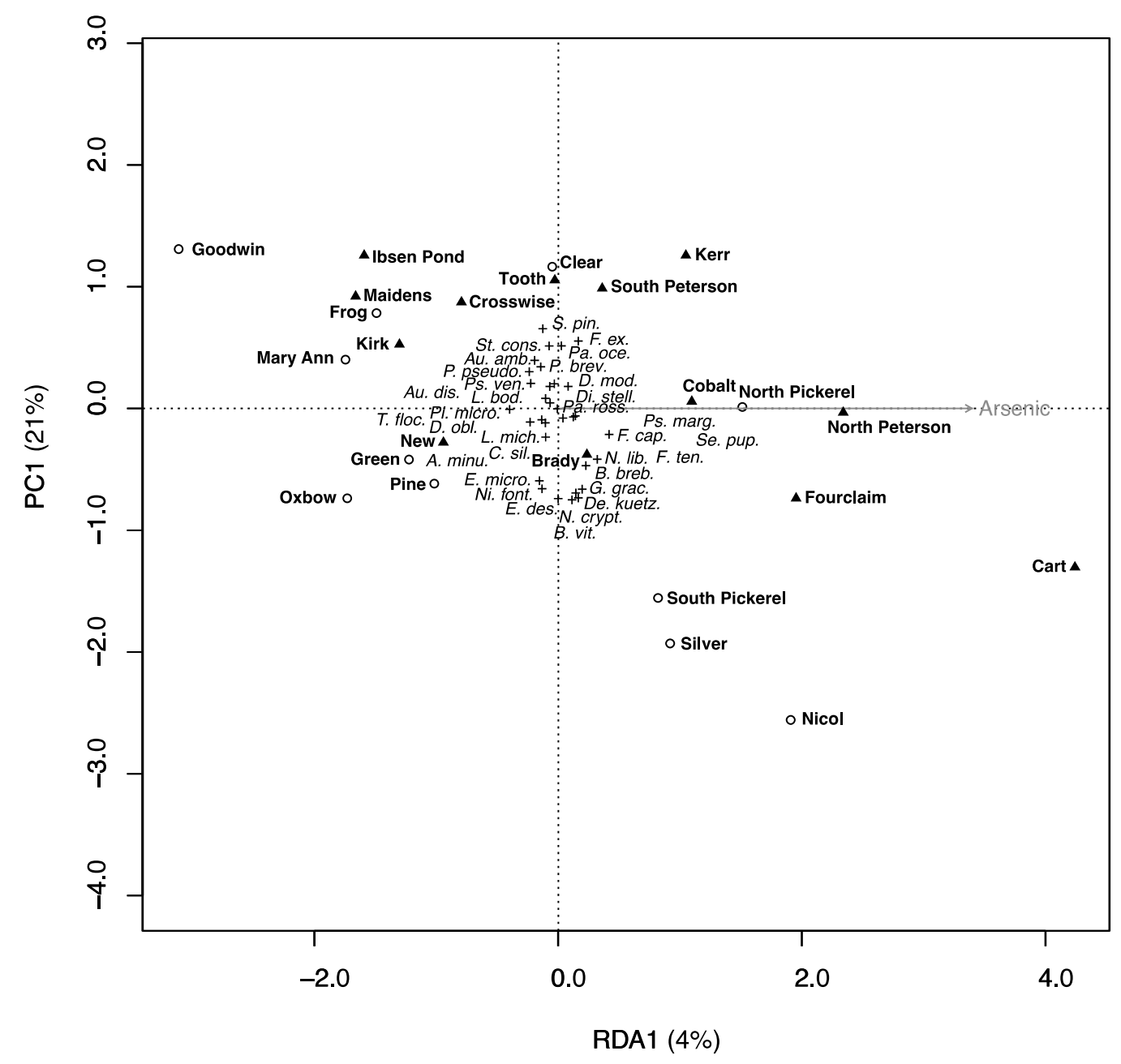

Figure 6-7: Contaminated lakes are indicated by black triangles, while currently uncontaminated lakes are represented by black circles. RDA ordination plot for diatom taxa from 24 lakes in the Cobalt, Ontario, Canada region. RDA1, or arsenic, explains $4 \%$ of the variance in the data. 

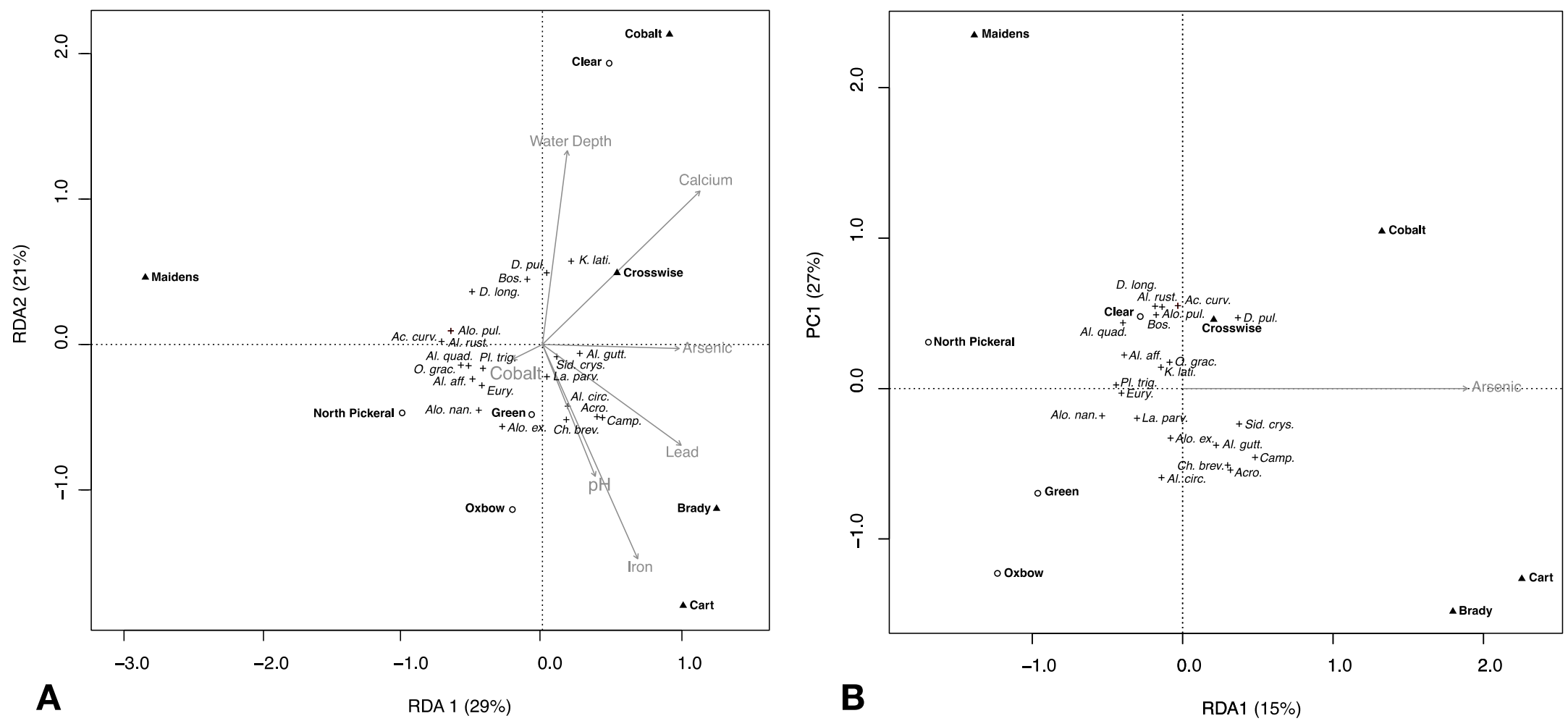

Figure 6-8: Contaminated lakes are indicated by black triangles, while currently uncontaminated lakes are represented by black circles. A) RDA ordination plot for cladocera taxa from 9 lakes in the Cobalt, Ontario, Canada region. RDA1 explains $29 \%$ of the variance in the data, while RDA2 explains $21 \%$. B) RDA ordination plot using only arsenic from the 9 lakes as an explanatory variable. Arsenic was found to explain $\sim 15 \%$ of the total variance in the cladocera taxa. 

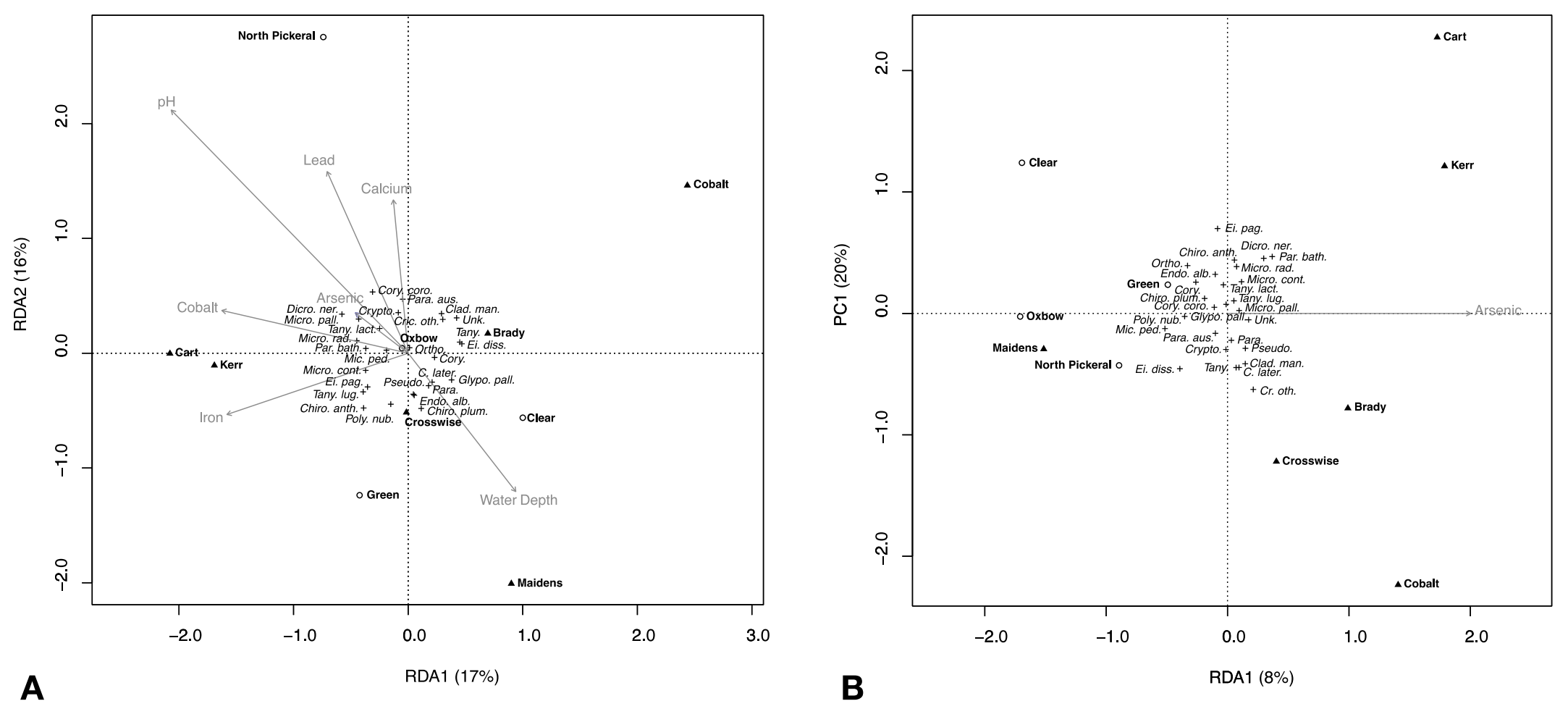

Figure 6-9: Contaminated lakes are indicated by black triangles, while currently uncontaminated lakes are represented by black circles. A) RDA ordination plot for chironomid taxa from 10 lakes in the Cobalt, Ontario, Canada region. RDA1 explains 17\% of the variance in the data, while RDA2 explains 15\%. B) RDA ordination plot using only arsenic from the 10 lakes as an explanatory variable. Arsenic was found to explain $\sim 8 \%$ of the total variance in the chironomid taxa. 

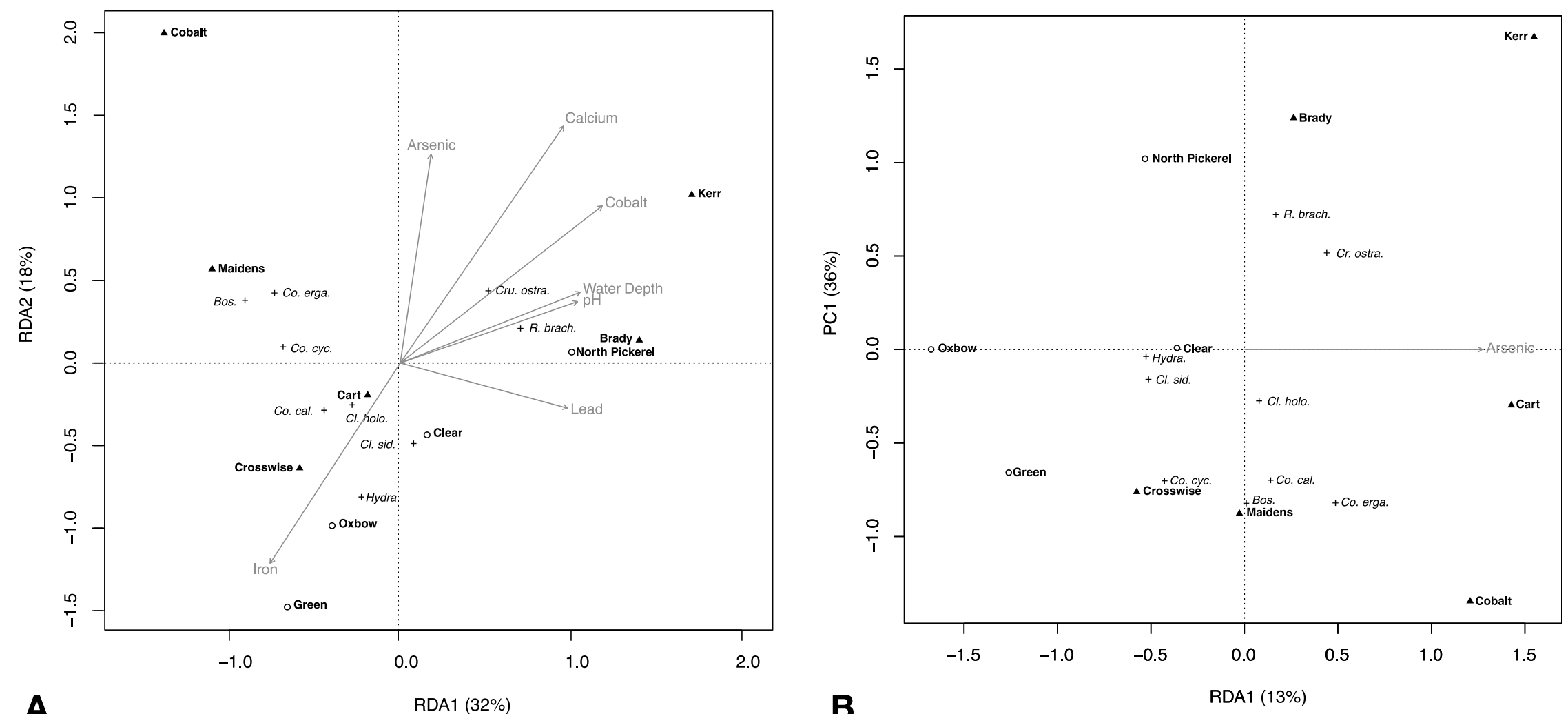

Figure 6-10: Contaminated lakes are indicated by black triangles, while currently uncontaminated lakes are represented by black circles. A) RDA ordination plot for zooplankton taxa from 10 lakes in the Cobalt, Ontario, Canada region. RDA1 explains 31\% of the variance in the data, while RDA2 explains 17\%. B) RDA ordination plot using only arsenic from the 10 lakes as an explanatory variable. Arsenic was found to explain $\sim 13 \%$ of the total variance in the zooplankton taxa. 


\section{BIO-INDICATOR TAXA RELATIONSHIPS WITH ARSENIC 1. DIATOMS}
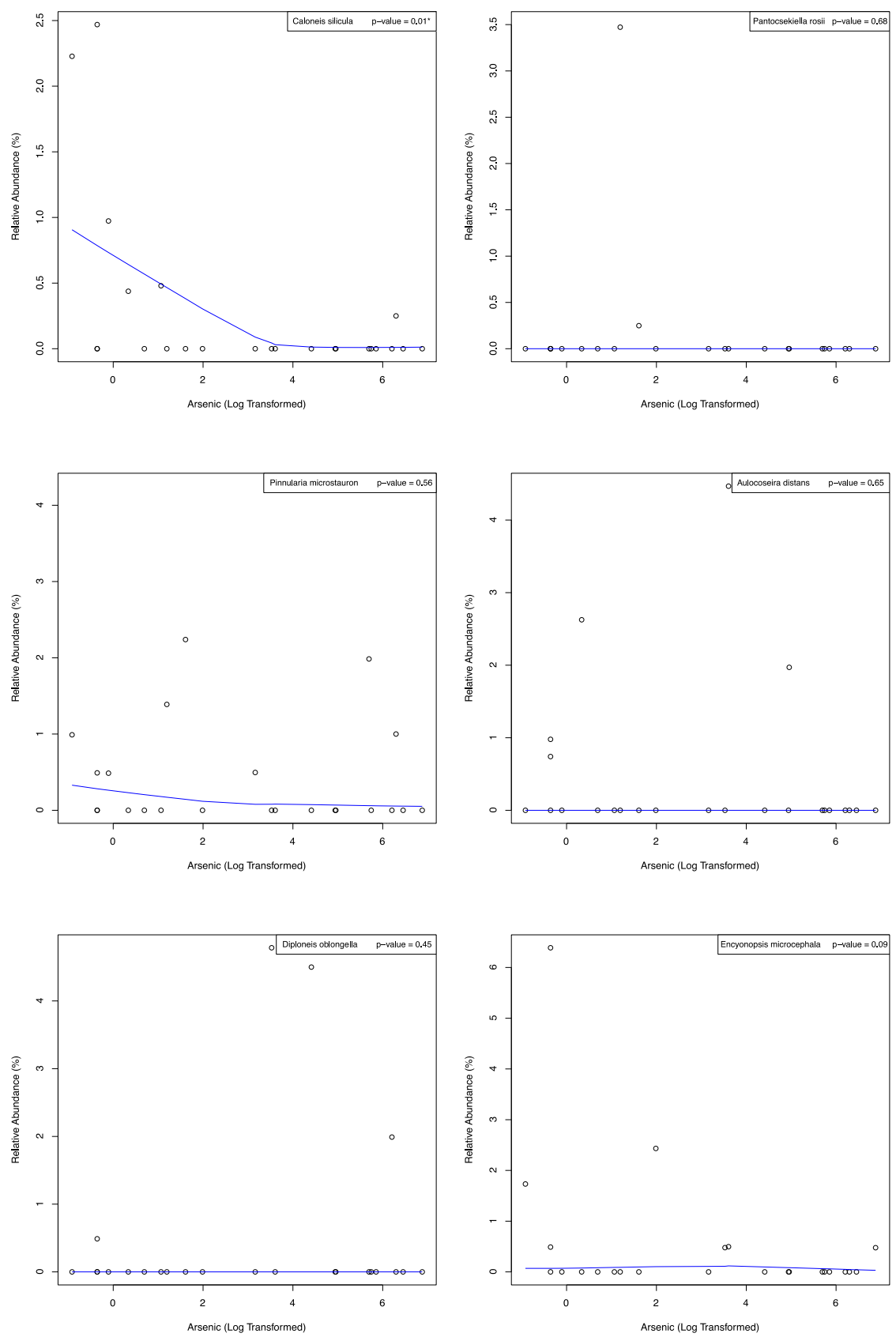

Figure 6-11: Diatom taxa 1-6 versus surface water arsenic from the 24-lake gradient from around the Cobalt, Ontario, Canada region. 

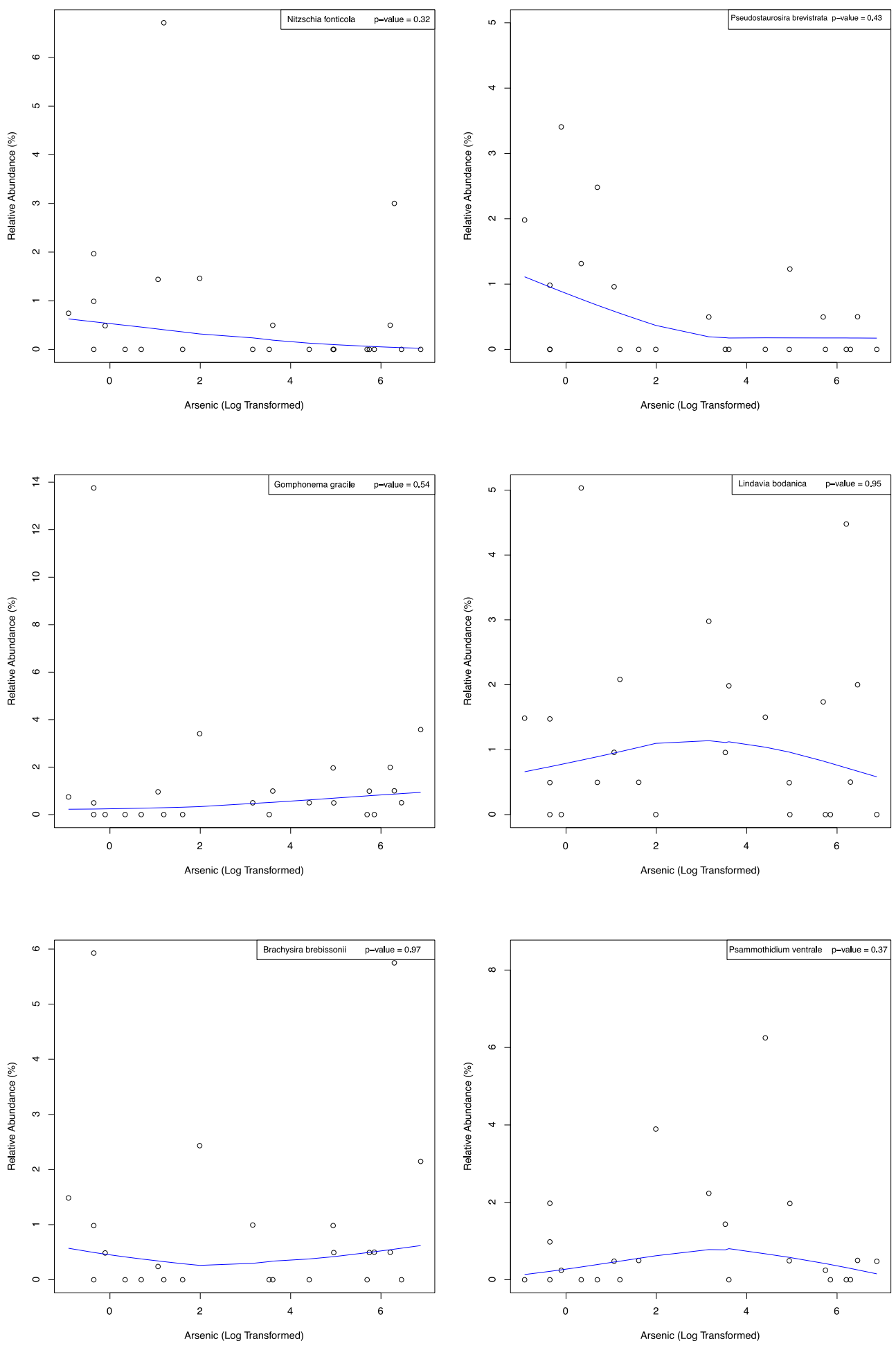

Figure 6-12: Diatom taxa 7-12 versus surface water arsenic from the 24-lake gradient from around the Cobalt, Ontario, Canada region. 

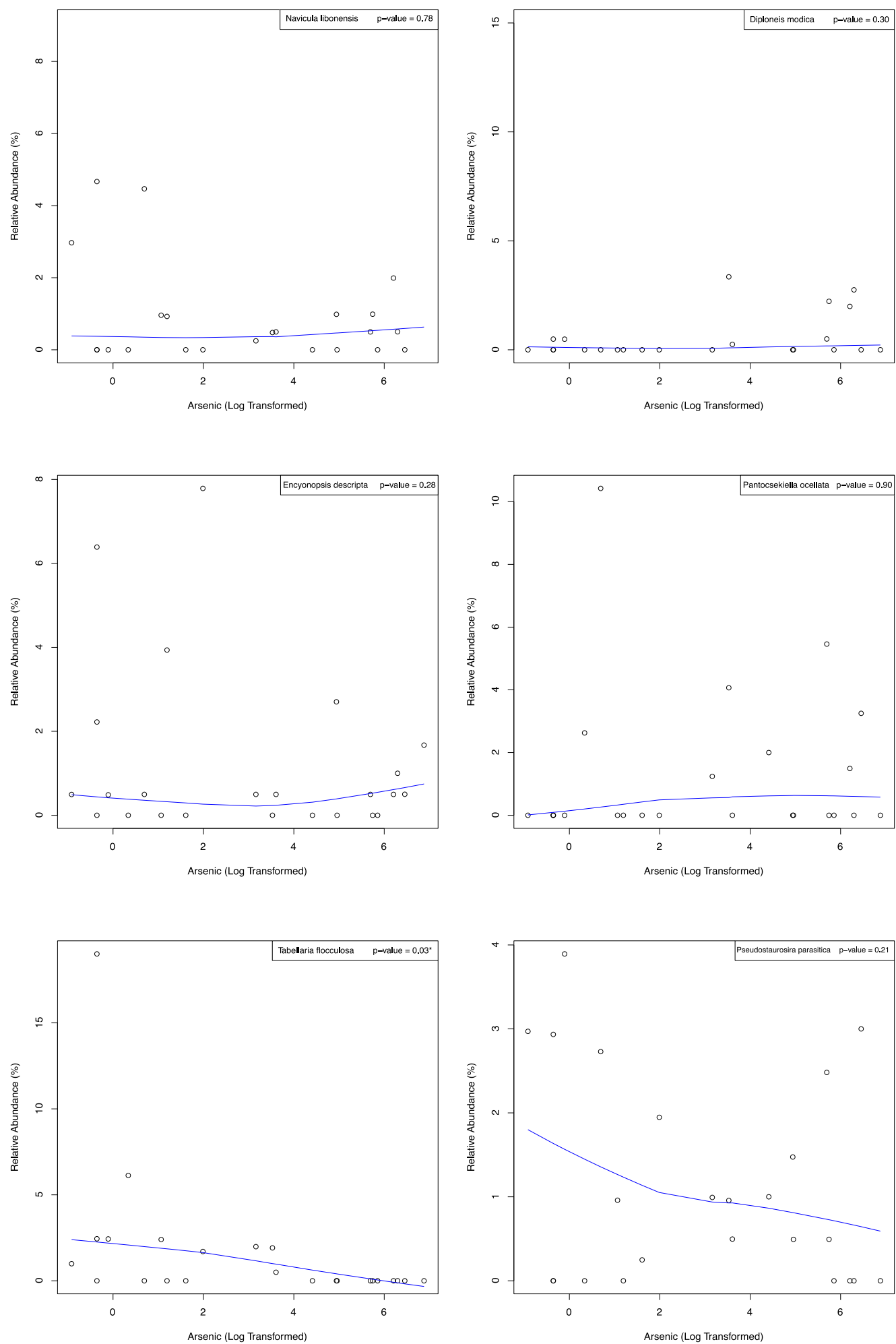

Figure 6-13: Diatom taxa 13-18 versus surface water arsenic from the 24-lake gradient from around the Cobalt, Ontario, Canada region. 

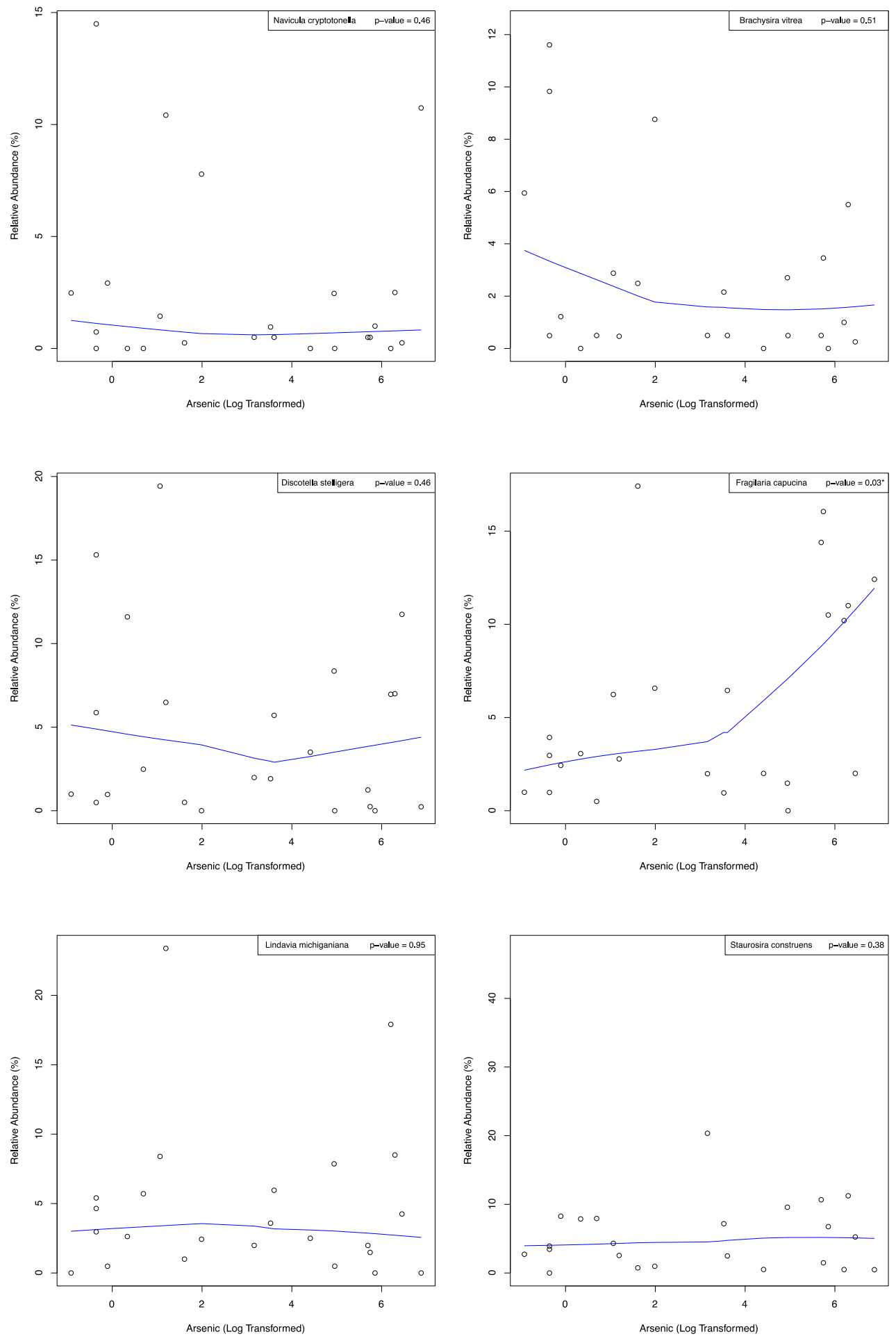

Figure 6-14: Diatom taxa 19-24 versus surface water arsenic from the 24-lake gradient from around the Cobalt, Ontario, Canada region. 

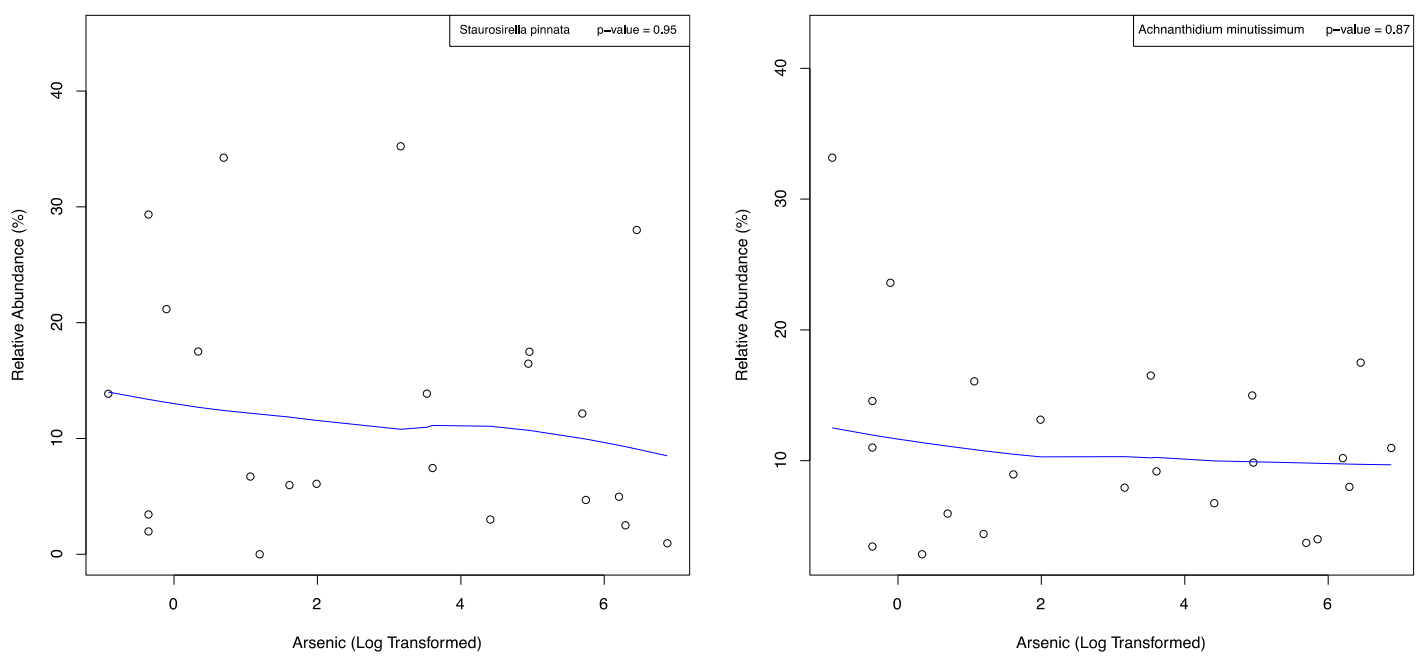

Figure 6-15: Diatom taxa 25-26 versus surface water arsenic from the 24-lake gradient from around the Cobalt, Ontario, Canada region. 


\section{CLADOCERA}
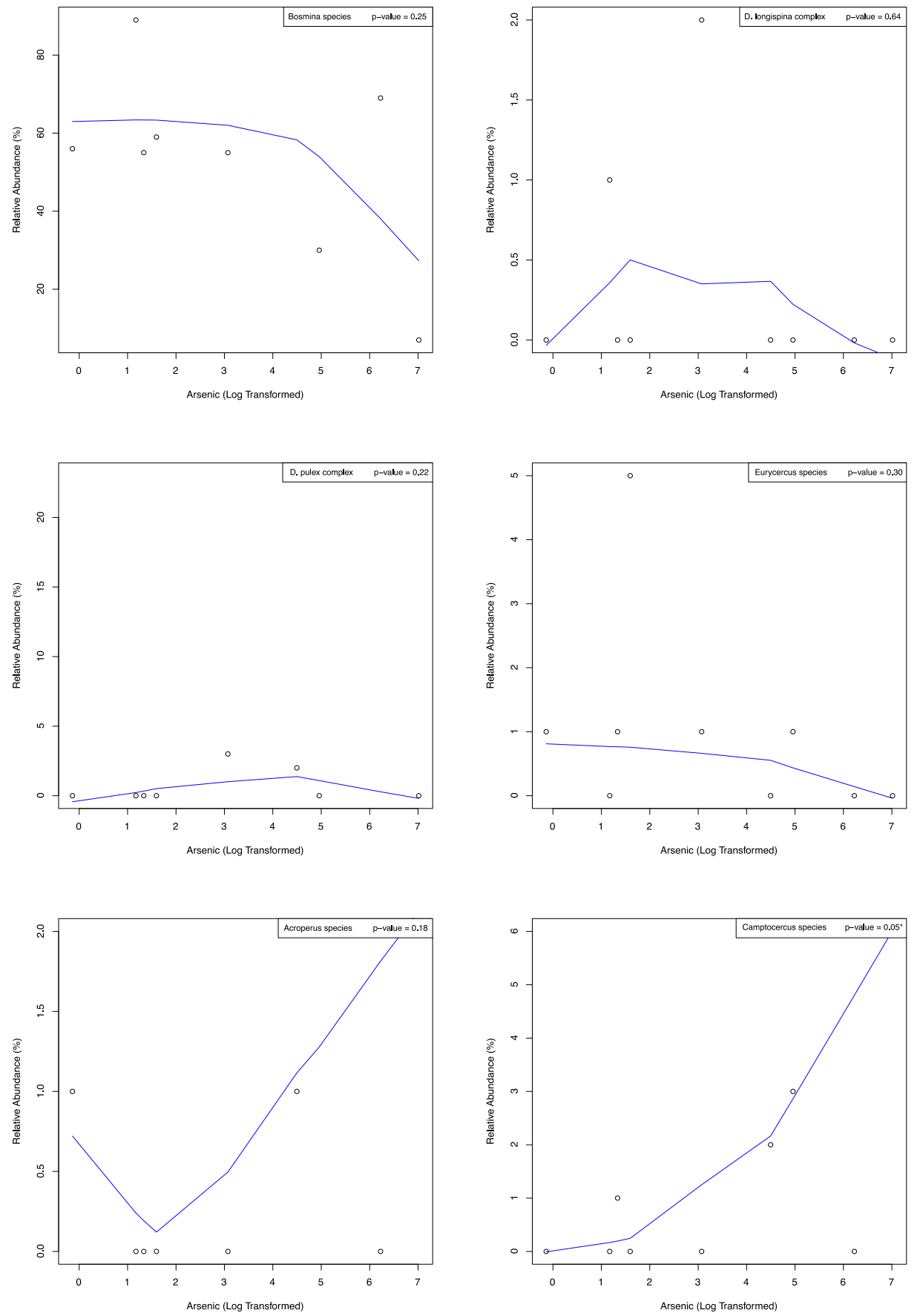

Figure 6-16: Cladocera taxa 1-6 versus surface water arsenic from the 10-lake gradient from around the Cobalt, Ontario, Canada region. 

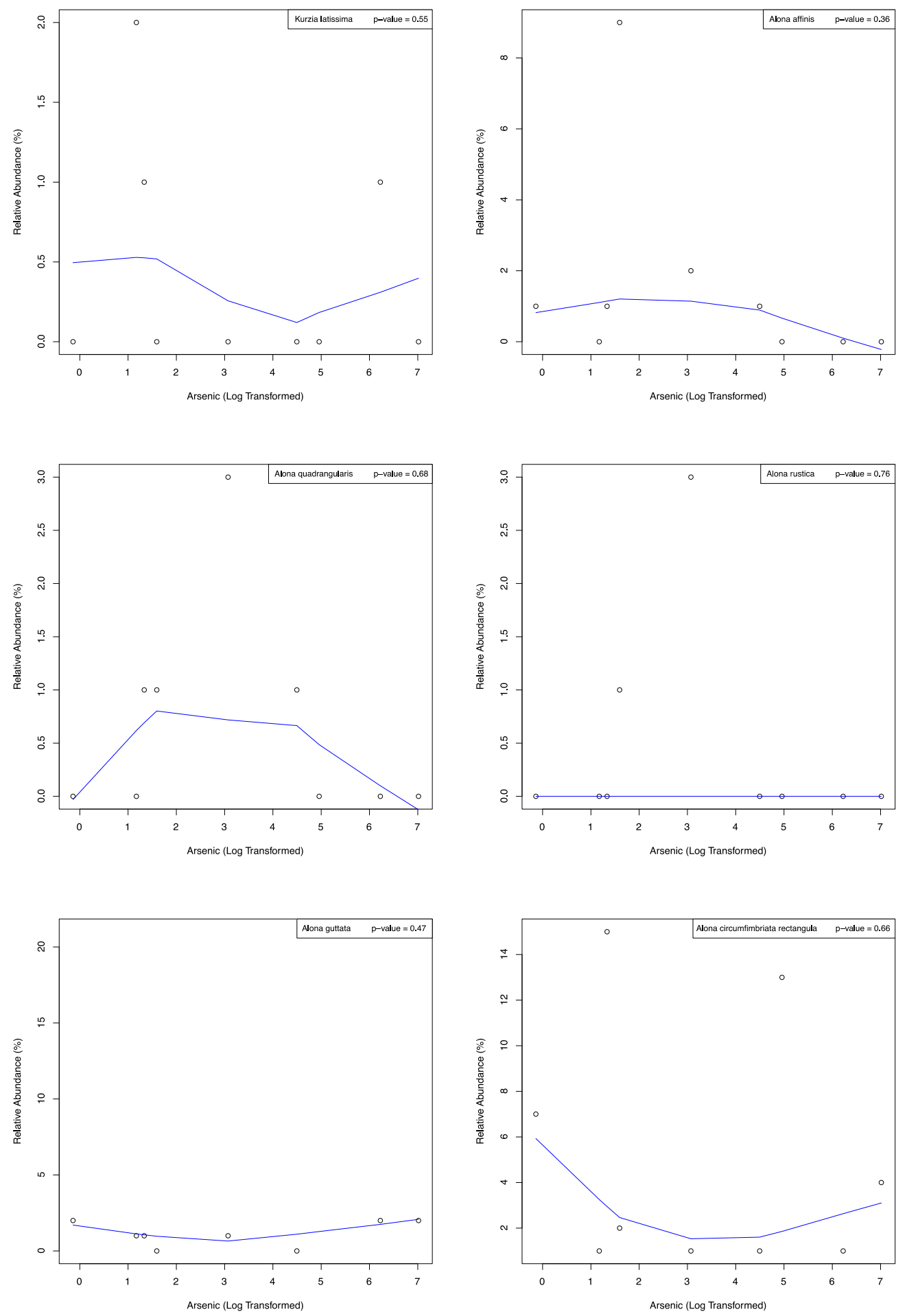

Figure 6-17: Cladocera taxa 7-12 versus surface water arsenic from the 10-lake gradient from around the Cobalt, Ontario, Canada region. 

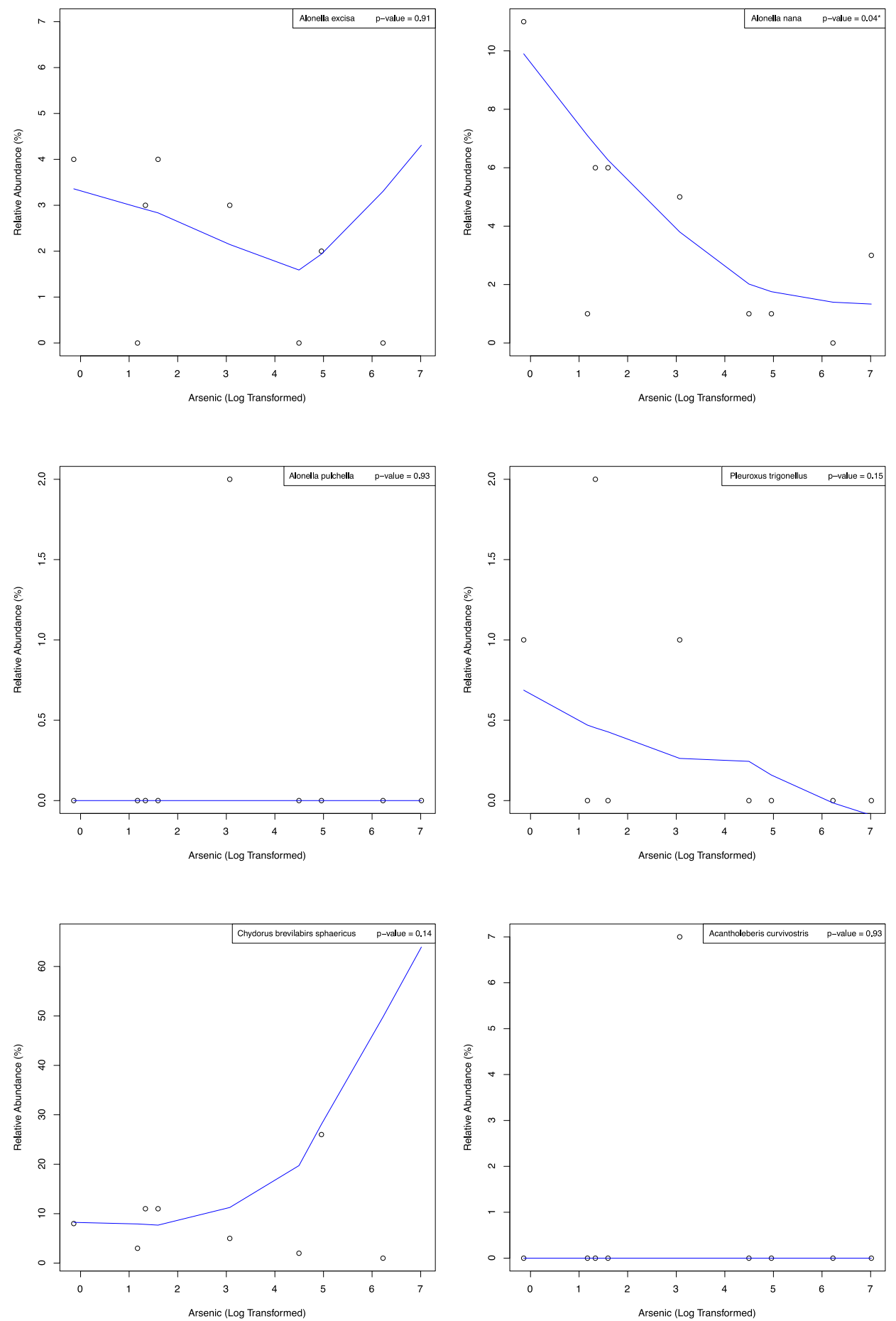

Figure 6-18: Cladocera taxa 13-18 versus surface water arsenic from the 10-lake gradient from around the Cobalt, Ontario, Canada region. 

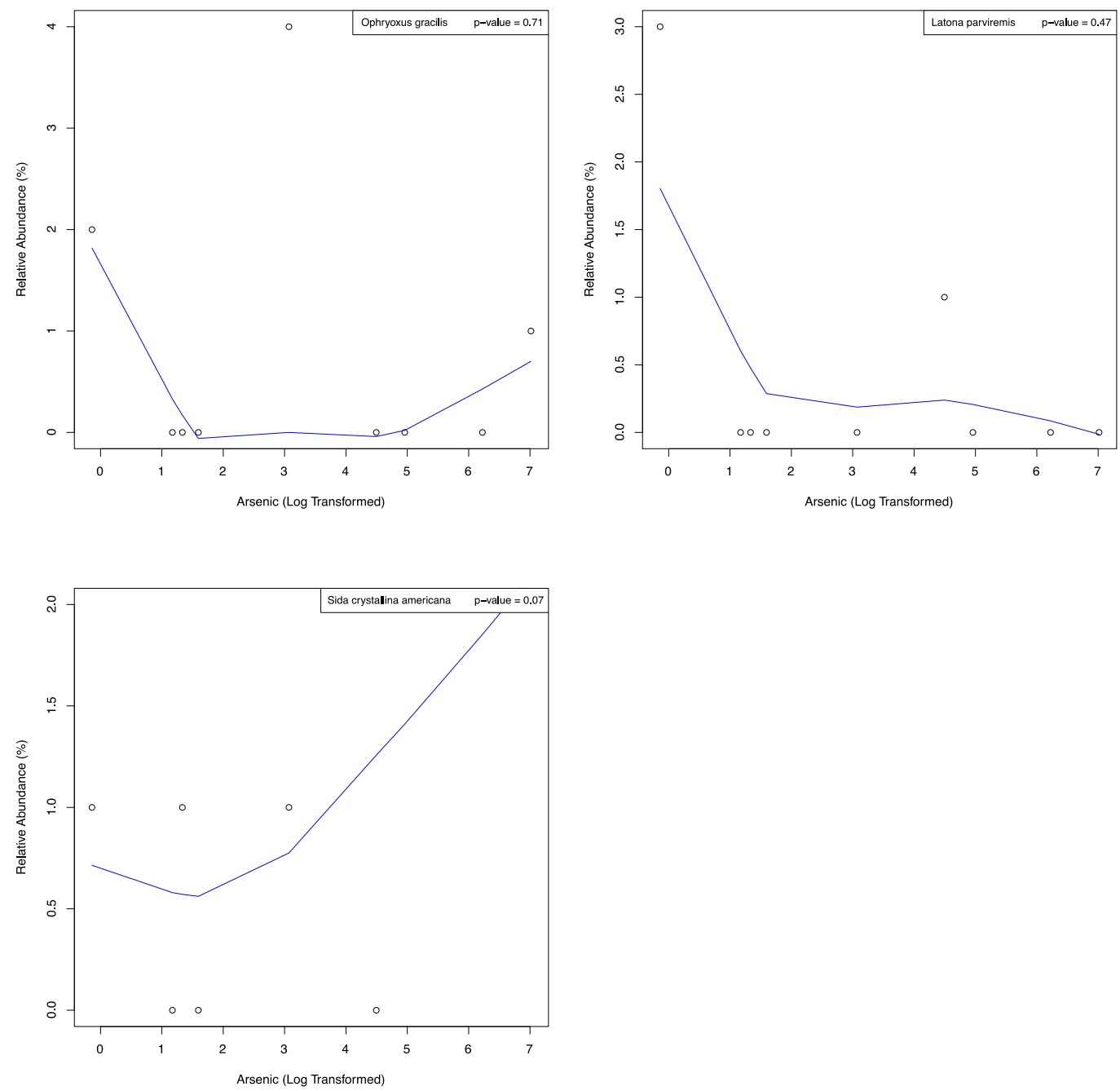

Figure 6-19: Cladocera taxa 19-21 versus surface water arsenic from the 10-lake gradient from around the Cobalt, Ontario, Canada region. 


\section{CHIRONOMIDS}
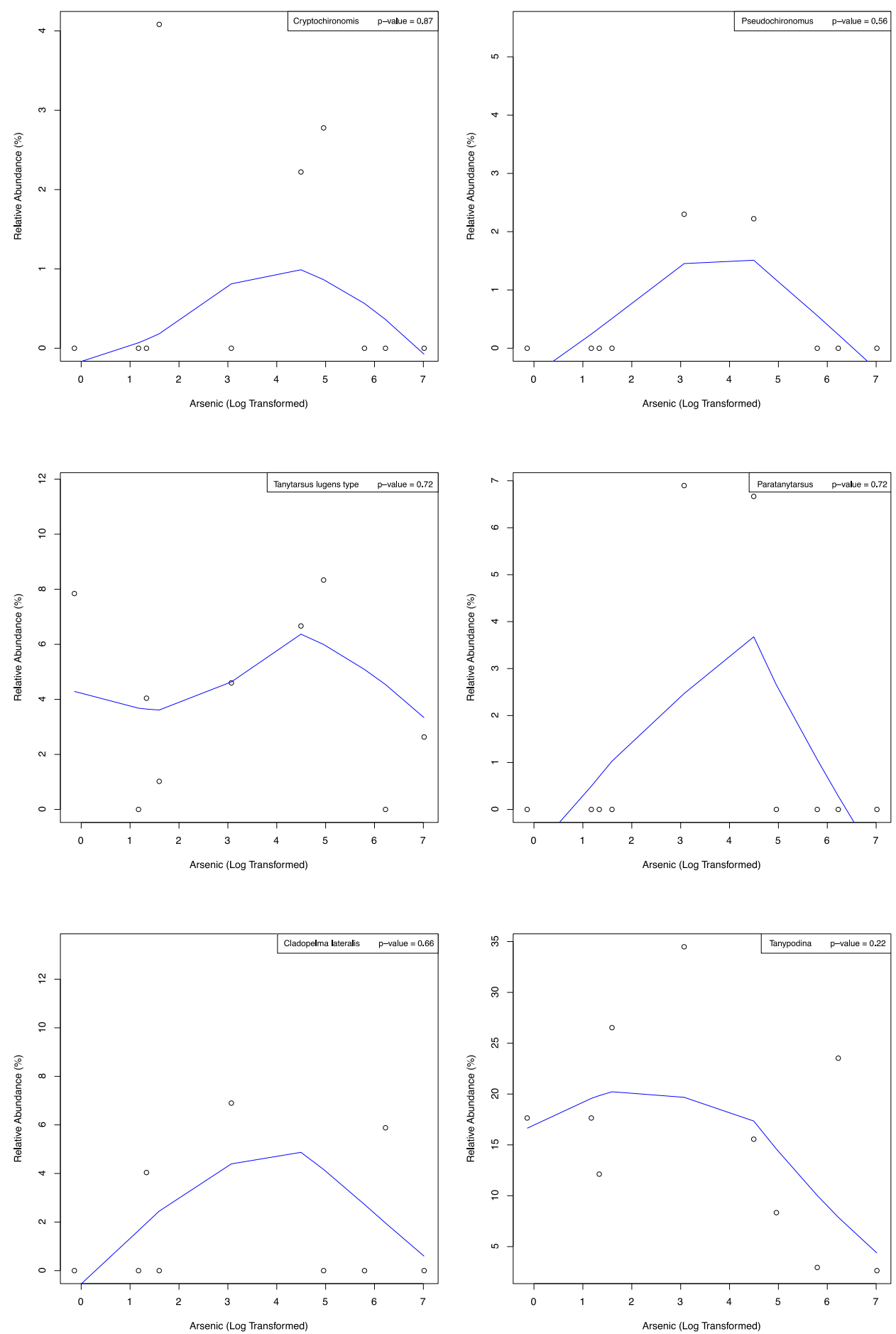

Figure 6-20: Chironomid taxa 1-6 versus surface water arsenic from the 10-lake gradient from around the Cobalt, Ontario, Canada region. 

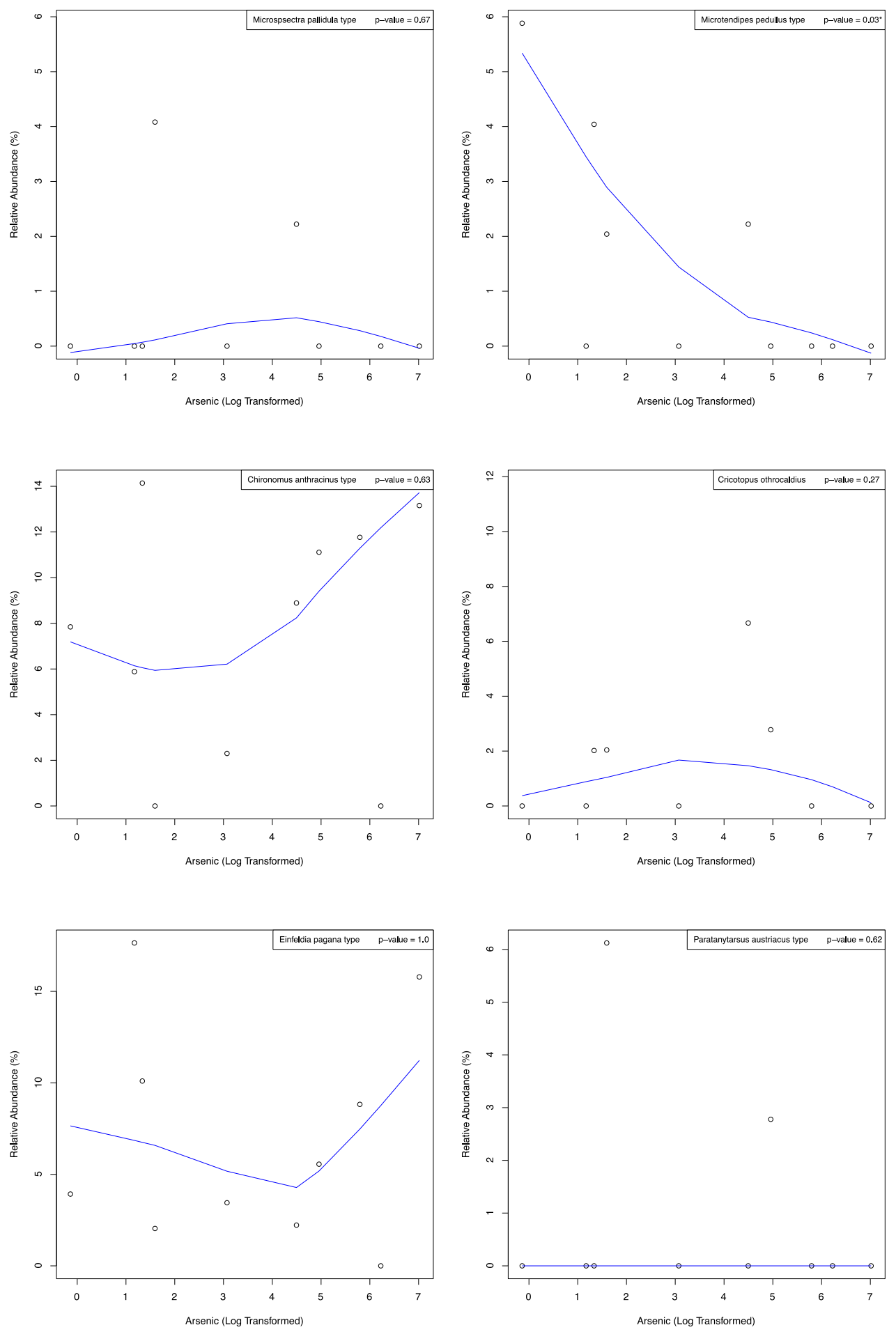

Figure 6-21: Chironomid taxa 7-12 versus surface water arsenic from the 10-lake gradient from around the Cobalt, Ontario, Canada region. 

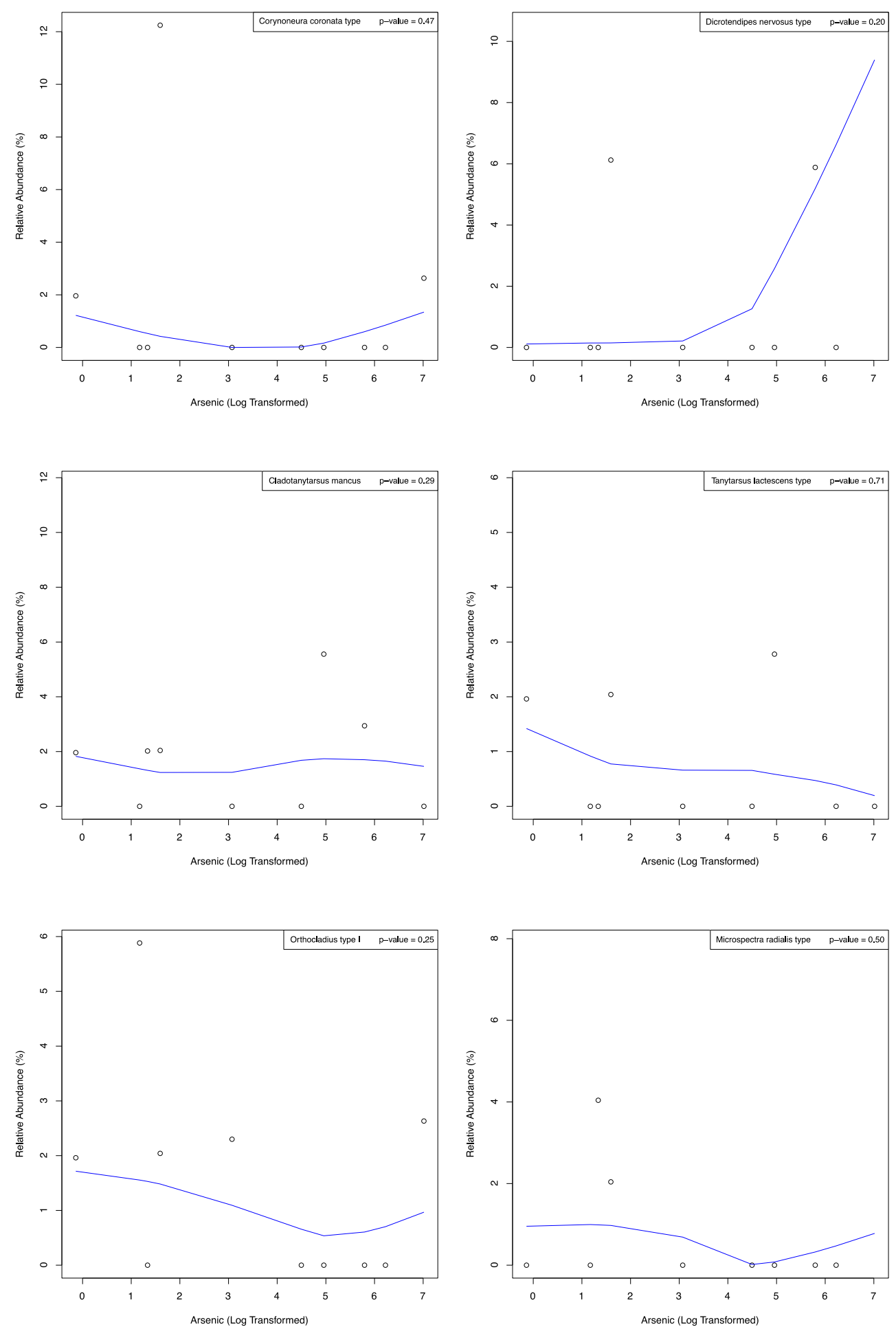

Figure 6-22: Chironomid taxa 13-18 versus surface water arsenic from the 10-lake gradient from around the Cobalt, Ontario, Canada region. 

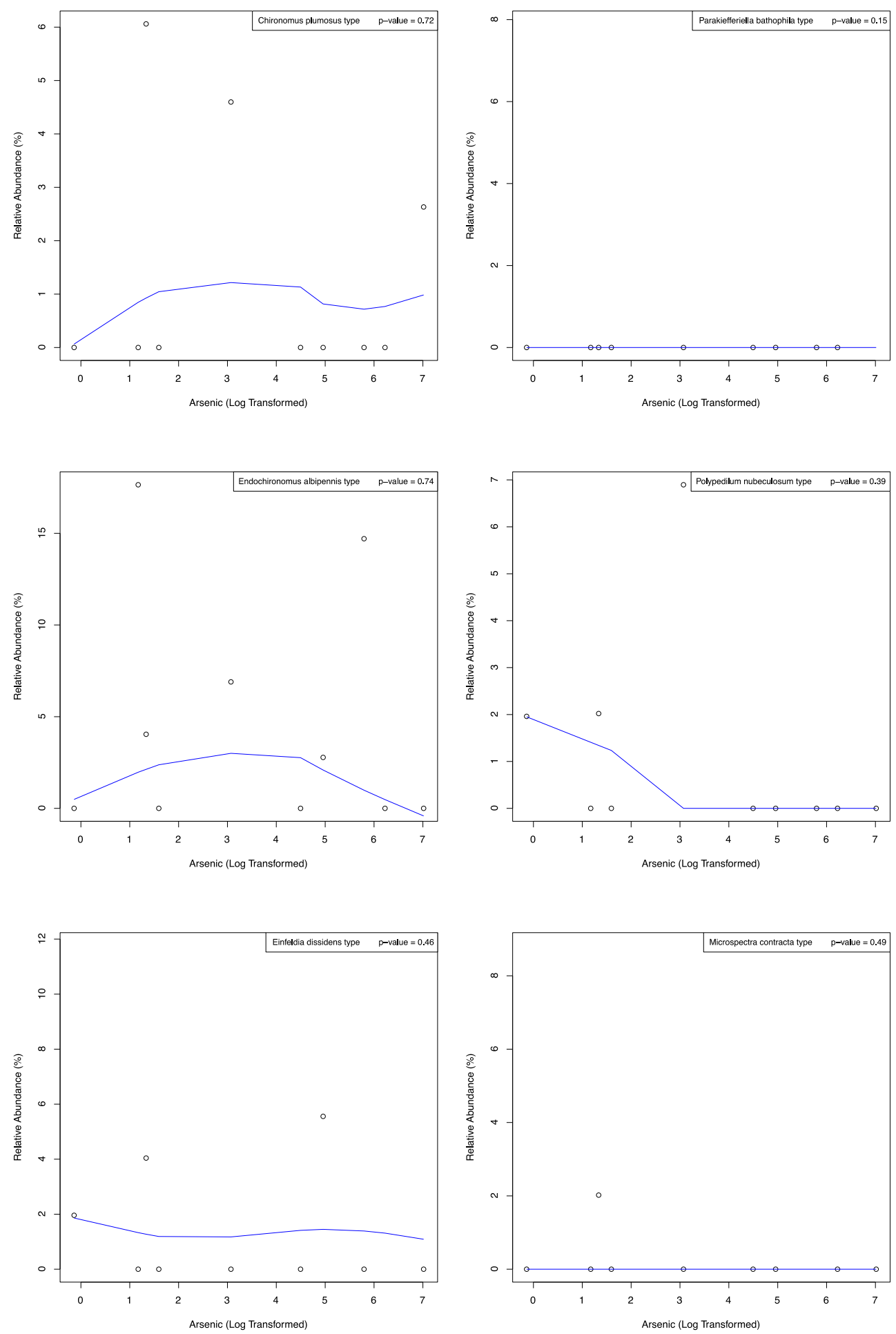

Figure 6-23: Chironomid taxa 19-24 versus surface water arsenic from the 10-lake gradient from around the Cobalt, Ontario, Canada region. 

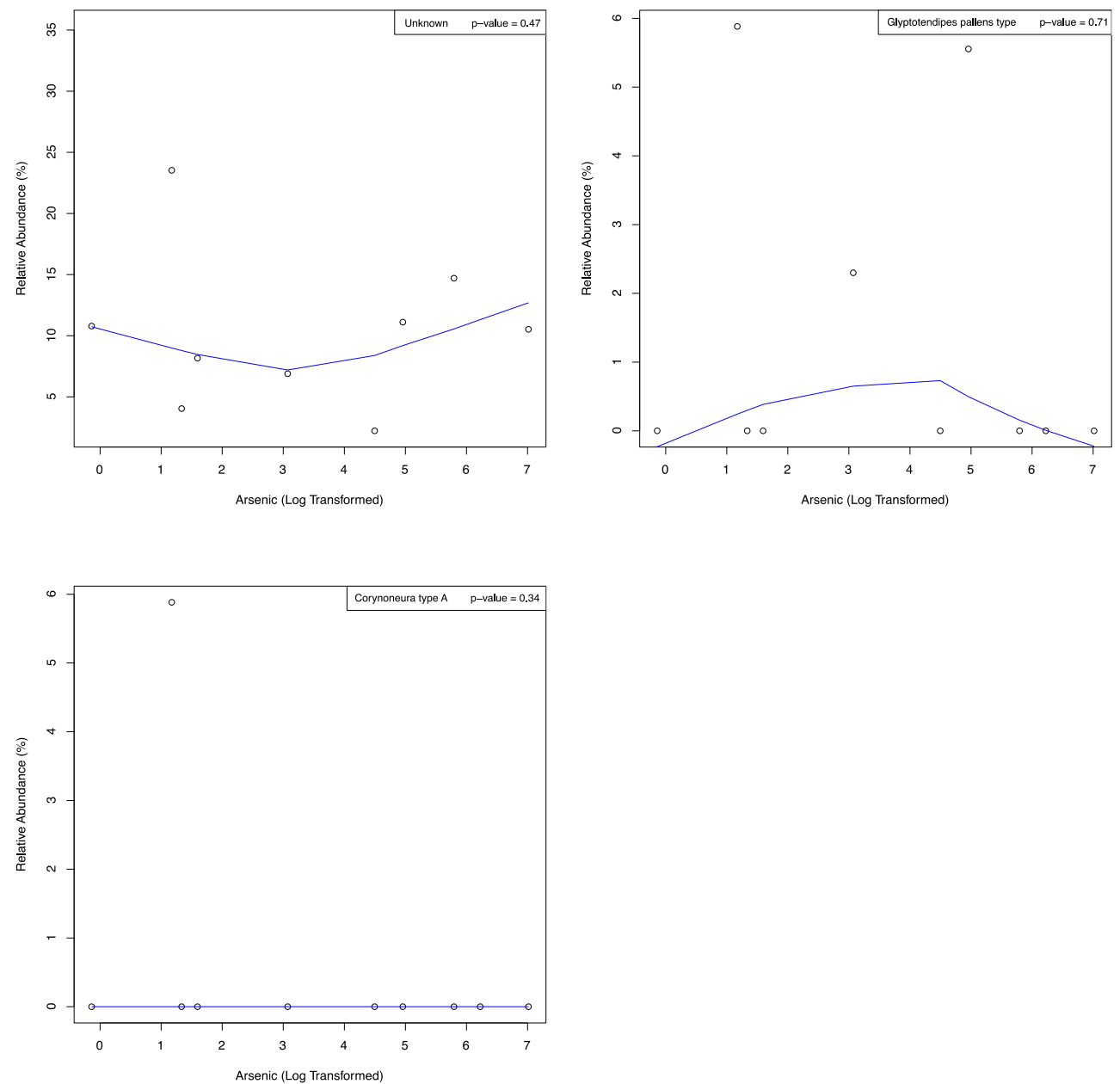

Figure 6-24: Chironomid taxa 25-27 versus surface water arsenic from the 10-lake gradient from around the Cobalt, Ontario, Canada region. 


\section{ZOOPLANKTON}
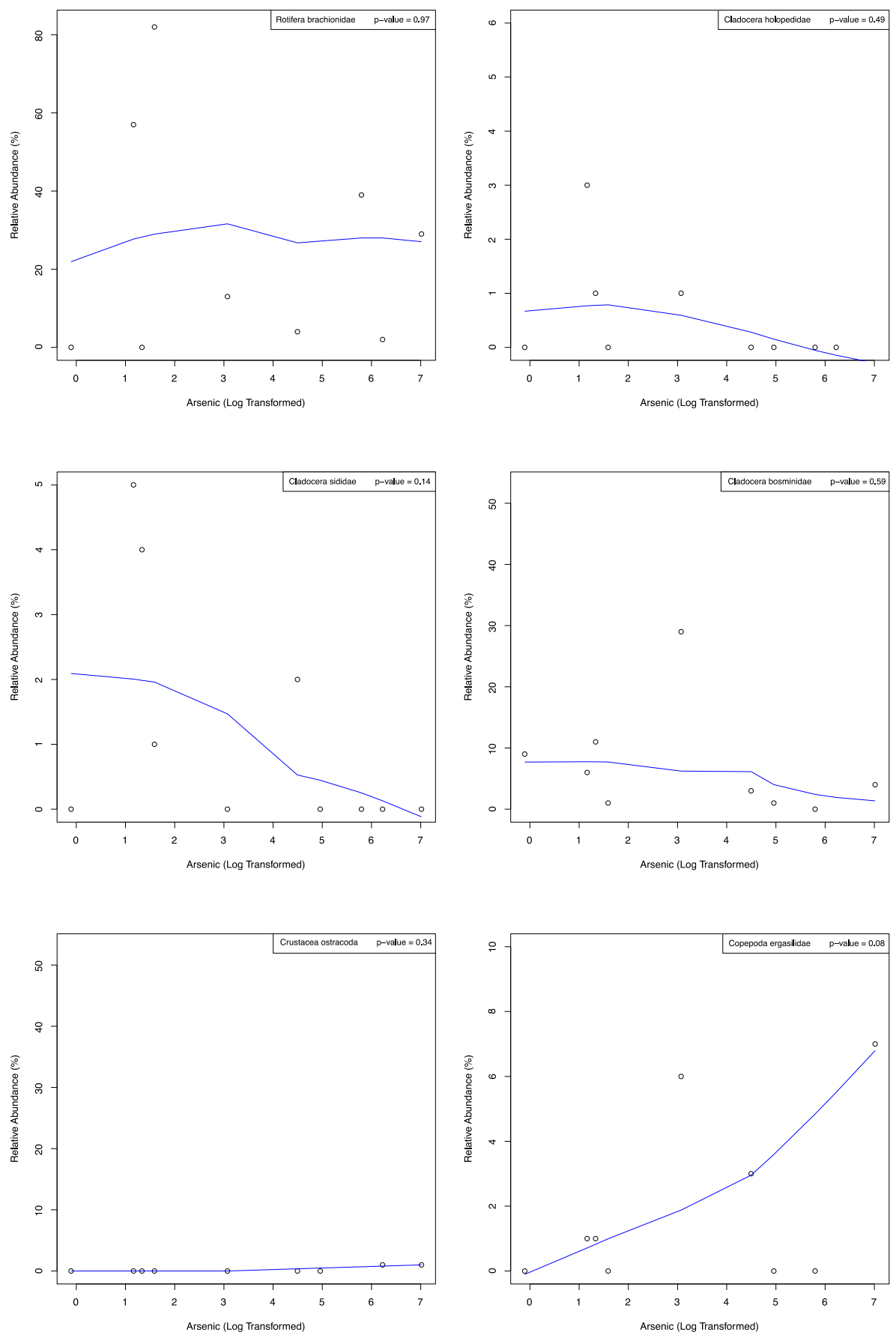

Figure 6-25: Zooplankton taxa 1-6 versus surface water arsenic from the 10-lake gradient from around the Cobalt, Ontario, Canada region. 

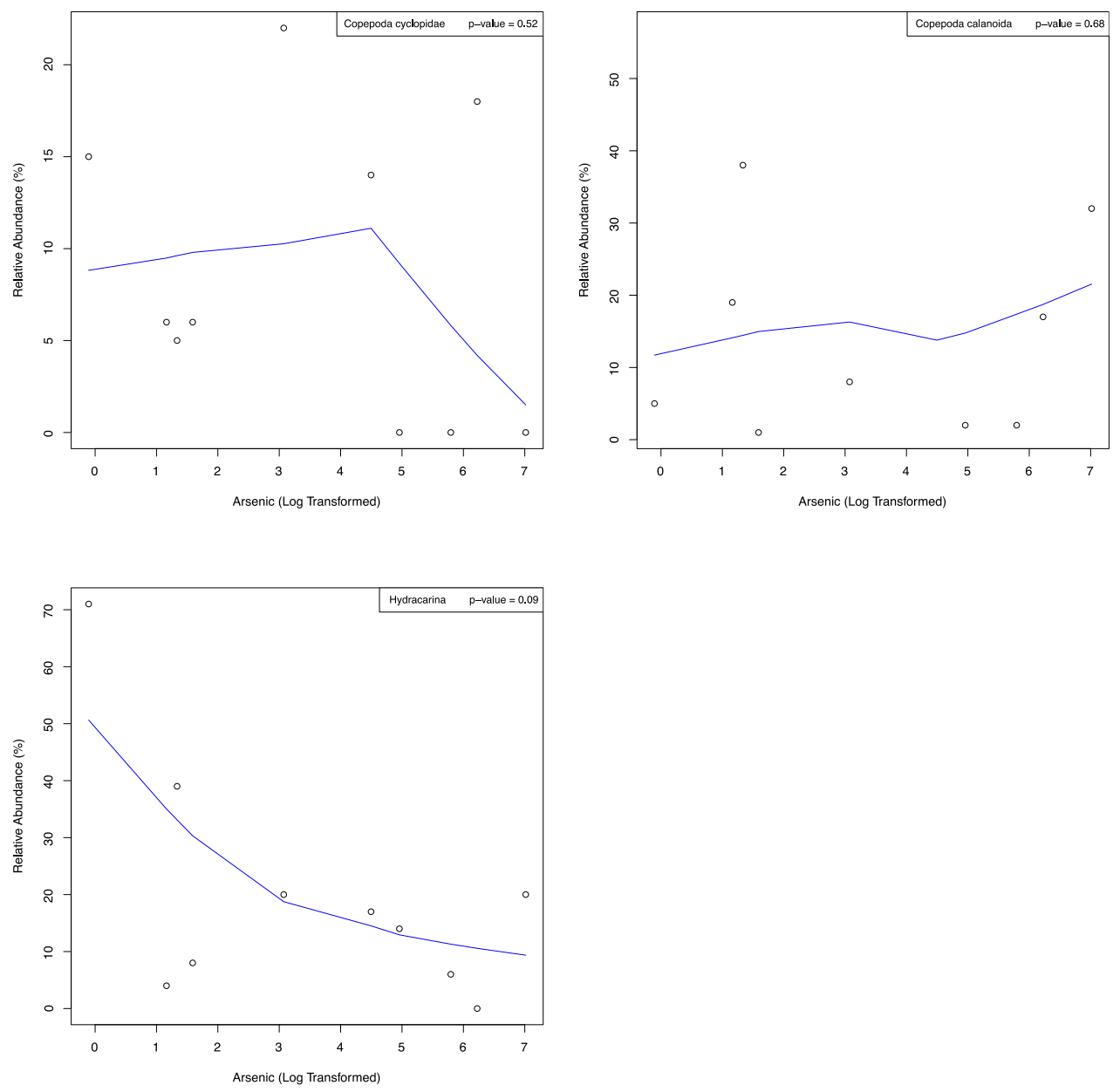

Figure 6-26: Zooplankton taxa 7-9 versus surface water arsenic from the 10-lake gradient from around the Cobalt, Ontario, Canada region. 


\section{E. SEDIMENTARY DATA}

Table 6-32: Sediment chemistry data from the 24-lake gradient from the Cobalt, Ontario region.

\begin{tabular}{|c|c|c|c|c|c|c|c|c|c|c|c|c|c|c|c|c|c|c|c|c|c|c|c|c|}
\hline $\begin{array}{c}\text { Environmental } \\
\text { Variables } \\
(\mu \mathrm{g} / \mathrm{g})\end{array}$ & 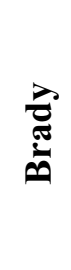 & 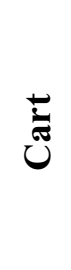 & $\frac{\grave{\circlearrowright}}{\bar{U}}$ & $\frac{\hbar}{\tilde{\sigma}}$ & $\frac{\mathscr{0}}{0}$ & 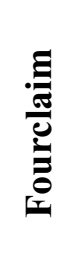 & 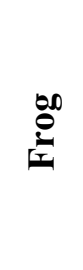 & ن & 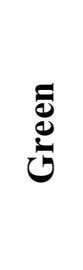 & 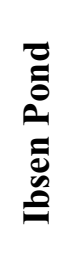 & 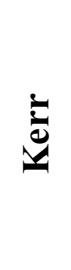 & 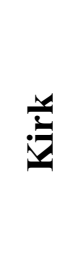 & 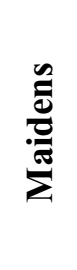 & 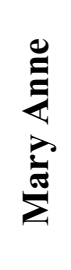 & $\frac{z}{z}$ & $\frac{0}{8}$ & 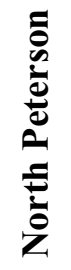 & 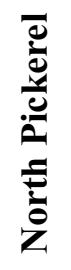 & $\frac{3}{0}$ & $\stackrel{\mathscr{E}}{\underline{E}}$ & $\sum_{\bar{\sigma}}^{\grave{2}}$ & 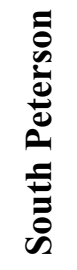 & 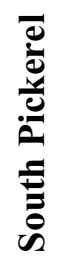 & $\stackrel{5}{\circ}$ \\
\hline Antimony & 85.3 & 31.1 & $<0.5$ & 97.5 & 35.9 & 55.7 & $<0.5$ & $<0.5$ & 3.8 & 14.8 & 12.9 & 41.2 & 6 & 1.7 & 13.1 & 1 & 105 & 0.9 & 0.8 & 1 & 0.7 & 79 & 2 & $<0.5$ \\
\hline Arsenic & 1950 & 4510 & 11 & 10800 & 1020 & 7420 & 7.8 & 2.6 & 109 & 3490 & 702 & 1160 & 185 & 13 & 492 & 12.8 & 2650 & 27 & 12.4 & 12 & 23 & 2050 & 48 & 37 \\
\hline Barium & 47 & 24 & 29 & 17 & 67 & 46 & 70 & 55 & 39 & 37 & 21 & 48 & 51 & 39 & 51 & 37 & 52 & 31 & 53 & 69 & 44 & 28 & 18 & 111 \\
\hline Beryllium & 0.5 & 1.4 & 0.3 & 1 & 1.4 & 1.1 & 0.4 & 0.4 & 0.2 & 0.5 & 0.3 & 0.8 & 0.5 & $<0.2$ & 0.3 & 0.2 & 1.2 & $<0.2$ & 0.4 & 0.7 & $<0.2$ & 1.6 & 0.2 & 0.5 \\
\hline Bismuth & 24 & 18 & $<5$ & 58 & 30 & 151 & $<5$ & $<5$ & $<5$ & 39 & $<5$ & 42 & $<5$ & $<5$ & 7 & $<5$ & 27 & $<5$ & $<5$ & $<5$ & $<5$ & 54 & $<5$ & $<5$ \\
\hline Boron & 9.1 & 6.3 & 7.2 & 6.1 & 6.3 & 7.3 & 10.3 & 7.8 & 10.3 & 9 & 9 & 6.7 & 6.4 & 13.7 & 10.7 & 8.9 & 8.1 & 5.1 & 6.8 & 8.6 & 8.9 & 11.1 & 9.9 & 3 \\
\hline Cadmium & 8.7 & 48.2 & $<0.5$ & 54 & 5.7 & 36.3 & 1.1 & 0.8 & 2.8 & 38.1 & 6 & 13.6 & 3.1 & 2.1 & 7.4 & 3.1 & 14.9 & 1.5 & 2.7 & 1.3 & 1.6 & 14.6 & 3.8 & $<0.5$ \\
\hline Chromium & 84 & 172 & 37 & 133 & 149 & 398 & 53 & 39 & 19 & 75 & 38 & 119 & 40 & 19 & 39 & 17 & 124 & 19 & 22 & 50 & 14 & 109 & 18 & 54 \\
\hline Cobalt & 387 & 623 & 13 & 2070 & 409 & 1510 & 11 & 7 & 27 & 961 & 583 & 458 & 56 & 9 & 107 & 6 & 569 & 5 & 12 & 12 & 10 & 431 & 11 & 17 \\
\hline Copper & 209 & 253 & 71 & 575 & 1400 & 283 & 87 & 45 & 113 & 386 & 107 & 357 & 120 & 78 & 130 & 80 & 5030 & 116 & 69 & 57 & 46 & 861 & 126 & 17 \\
\hline Iron & 65900 & 67400 & 21800 & 74100 & 79600 & 77300 & 11200 & 10200 & 16300 & 39700 & 16200 & 55600 & 13600 & 8520 & 14500 & 5020 & 68900 & 7560 & 9180 & 26100 & 3380 & 59200 & 9640 & 25000 \\
\hline Lead & 224 & 332 & 6 & 274 & 343 & 107 & 14 & 12 & 99 & 292 & 78 & 302 & 78 & 55 & 140 & 98 & 377 & 25 & 72 & 38 & 33 & 1080 & 120 & 8 \\
\hline Manganese & 782 & 827 & 420 & 827 & 901 & 1350 & 203 & 218 & 235 & 592 & 600 & 998 & 203 & 64 & 413 & 37 & 863 & 81 & 263 & 405 & 50 & 552 & 100 & 334 \\
\hline Molybdenum & 5 & 8 & 1 & 25 & 5 & 7 & 1 & $<1$ & 2 & 5 & 1 & 6 & 3 & 2 & 3 & 2 & 6 & 3 & 2 & 1 & 2 & 4 & 2 & $<1$ \\
\hline Nickel & 108 & 259 & 40 & 719 & 996 & 669 & 32 & 22 & 63 & 160 & 145 & 197 & 69 & 49 & 56 & 46 & 1860 & 29 & 56 & 33 & 40 & 240 & 60 & 37 \\
\hline Selenium & 1.1 & 0.9 & 2.3 & 1 & 1.5 & 1.5 & 2.5 & 1.4 & 4.4 & 2.2 & 1 & 1.4 & 3.6 & 3.1 & 2 & 3.6 & 2.6 & 2.3 & 3.1 & 2.9 & 2.2 & 1.2 & 5.3 & 0.5 \\
\hline Silver & 79.7 & 51 & $<0.2$ & 109 & 88.9 & 181 & 1.2 & 0.2 & 2.5 & 59.1 & 11.6 & 90.3 & 2.4 & 1.1 & 10.4 & 0.7 & 164 & 1.3 & 0.3 & 2.8 & 0.8 & 206 & 2.7 & $<0.2$ \\
\hline Thallium & 0.2 & 0.1 & 0.2 & $<0.1$ & 0.2 & 0.1 & 0.2 & 0.1 & 0.2 & 0.2 & 0.1 & 0.2 & 0.2 & 0.2 & 0.1 & 0.2 & 0.2 & 0.1 & 0.2 & 0.3 & 0.1 & $<0.1$ & 0.2 & 0.1 \\
\hline Titanium & 895 & 808 & 418 & 590 & 1370 & 674 & 309 & 230 & 137 & 479 & 188 & 1280 & 220 & 133 & 259 & 99 & 721 & 120 & 108 & 218 & 82 & 427 & 141 & 771 \\
\hline Uranium & 0.8 & 1.6 & 2.1 & 2.2 & 2.6 & 1.3 & 3.6 & 4.3 & 0.9 & 2 & 1.2 & 2.1 & 3.3 & 2.1 & 1.6 & 2.2 & 2.3 & 1.1 & 1.2 & 6.1 & 2.2 & 2.3 & 1 & 1 \\
\hline
\end{tabular}


Vanadium

Zinc 